NAGY GÁBOR DÁNIEL

Társadalmi tőke és terïleti kötődés Magyarországon

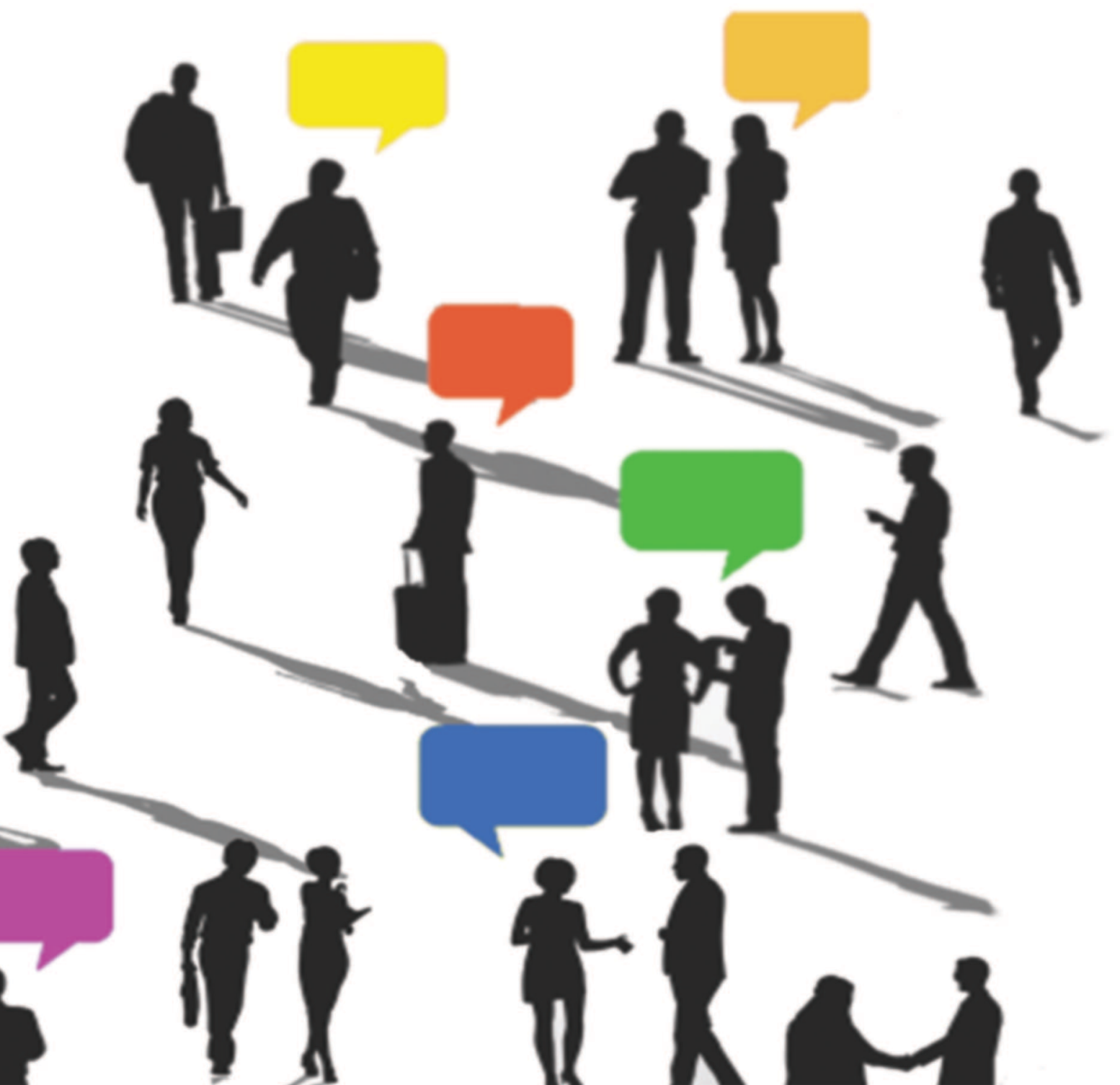


Társadalmi tőke és területi kötődés Magyarországon 
Nagy Gábor Dániel

\section{TÁRSADALMI TŐKE ÉS TERÜLETI KÖTŐDÉS MAGYARORSZÁGON}

\section{BF䇥}

Szeged, 2016 
A kötet megjelenését támogatta:

Nemzeti Kulturális Alap

\section{na}

Nemzeti Kulturális Alap

\section{Lektorálta:}

Füzér Katalin

Boritóterv:

Majzik Andrea

A szerző köszönetét fejezi ki Pálné Kovács Ilonának

ISBN 978-963-9573-98-7 (print)

ISBN 978-963-9573-94-9 (pdf)

CC Nagy Gábor Dániel, 2016

(C) Belvedere Meridionale, 2016 


\section{TARTALOM}

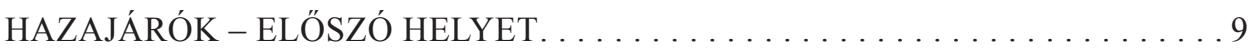

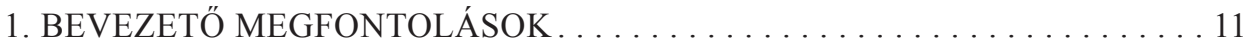

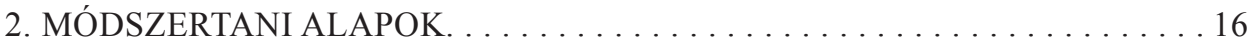

2.1 A standard eurobarometer nemzetközi összehasonlító kérdőíves kutatás

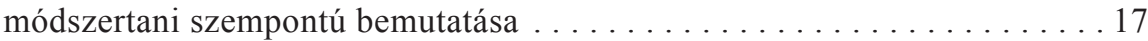

2.2 Az európai társadalomtudományi elemzések (ess) módszertani szempontú

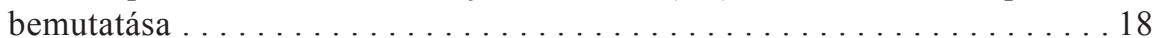

2.3 Szeged studies 2004 kutatás bemutatása . . . . . . . . . . . . . . . . . . 19

2.4 Invariancia mérés konfirmációs faktorelemzés segítségével. . . . . . . . . 19

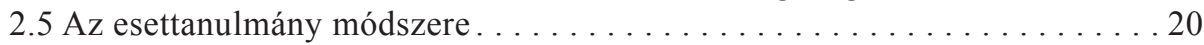

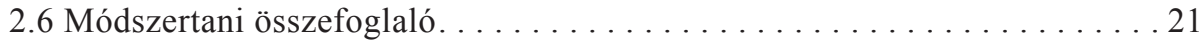

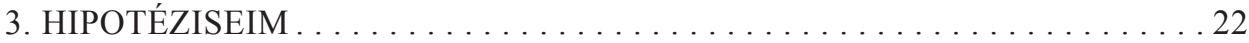

4. A TÁRSADALMI TÖKE ELMÉLET ALAPJAI . . . . . . . . . . . . . . . 24

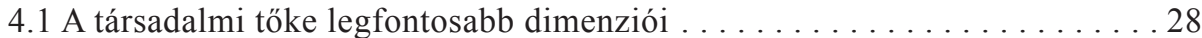

4.2 A társadalmi tőke szerepe a demokratikus társadalmakban. . . . . . . . . . 29

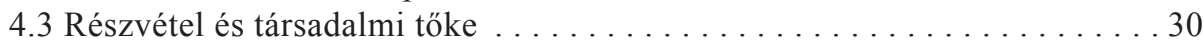

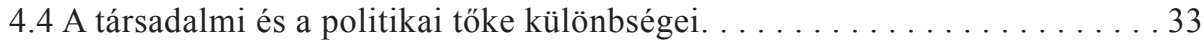

4.5 A társadalmi tőke különbségei a többi tőketípushoz képest . . . . . . . . 35

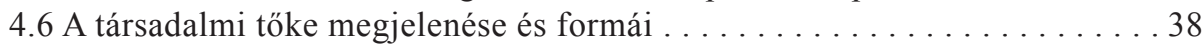

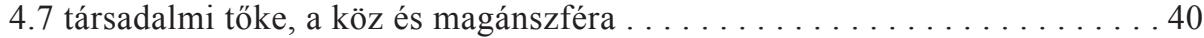

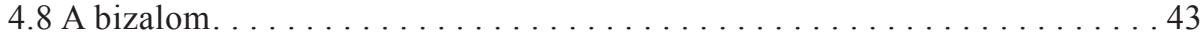

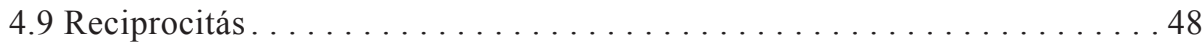

4.9.1 Szolidaritás - reciprocitás azonnali viszonzás nélkül . . . . . . . . 50

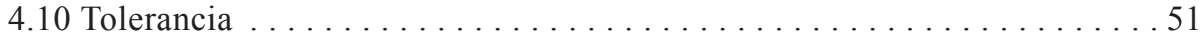

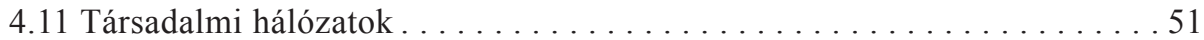

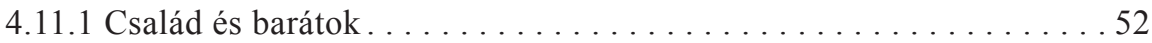

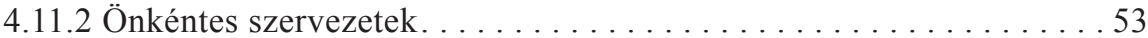

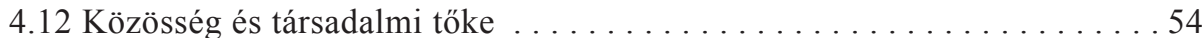

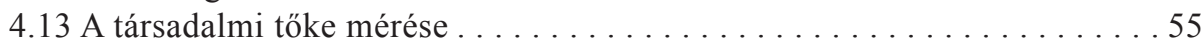

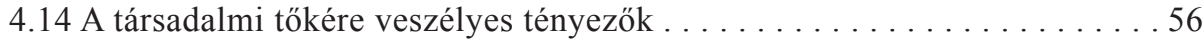

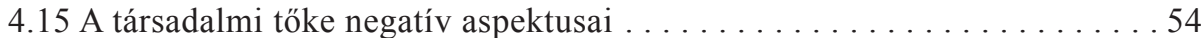

4.16 Következtetések. . . . . . . . . . . . . . . . . . 60

5. A TERÜLETI IDENTITÁS ÉS KÖTÖDÉS ELMÉLETI ALAPJAI . . . . . . . . 63

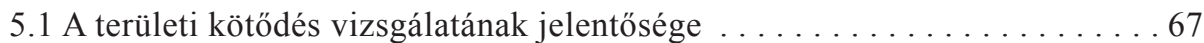




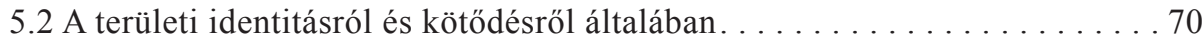

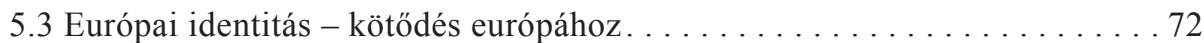

5.4 Regionális identitás - kötődés a régióhoz $\ldots \ldots \ldots \ldots \ldots \ldots \ldots$

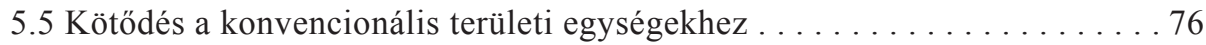

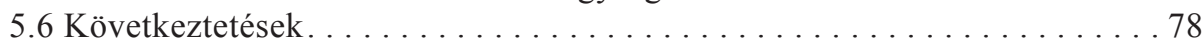

6. A TÁRSADALMI TÖKE ÉS A TERÜLETI IDENTITÁS VISZONYA . . . . . . . 79

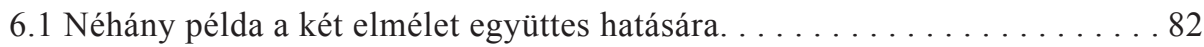

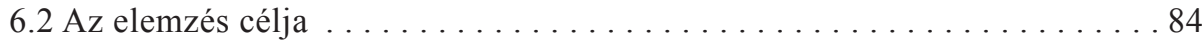

7. A REGIONÁLIS LAKOSSÁGI FELMÉRÉSEK VÉGZÉSÉNEK ÉS ÖSSZEHASONLÍTHATÓSÁGÁNAK KIHÍVÁSAI . . . . . . . . . . . . . 87

7.1 Példa a regionális összehasonlítás szükségességére: a regionális politikák

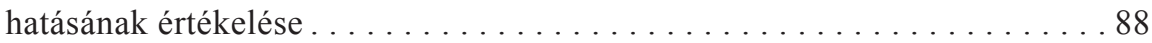

$7.2 \mathrm{Az}$ összehasonlítás lehetséges módszerei és keretei . . . . . . . . . . . . 89

7.3 Regionális összehasonlítások a magyar régiók lakossága esetében . . . . . 994

7.3.1 A területi hatalmi koncentráció kérdésköre . . . . . . . . . . . . 994

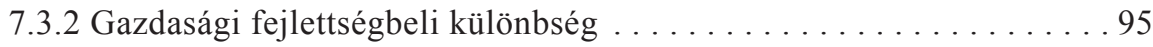

7.3 .3 Töredezett településszerkezet . . . . . . . . . . . . . . . 95

7.3.4 Aszinkronitás a településstruktúra és a társadalom átalakulása között . . . . . . . . . . . . . . . . .

7.3 .5 A cigány népesség regionális megoszlása . . . . . . . . . . . . 97

7.4 Modell az adatok összehasonlíthatóságának (invarianciájának) tesztelésére 98

7.4.1 A mérési súlyokat egyenlőnek tételező (measurement weights) modell . . 101

7.4.2 A mérési metszéspontokat egyenlőnek tételező (measurement intercepts) modell . . . . . . . . . . . . . . . . . . . . . . . . . . . . . . . . . . . . 102

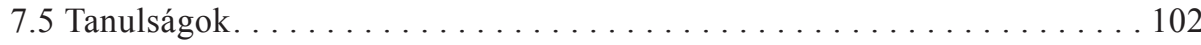

8. A TÁRSADALMI TÖKE VIZSGÁLATA A MAGYAR RÉGIÓKBAN . . . . . . 104

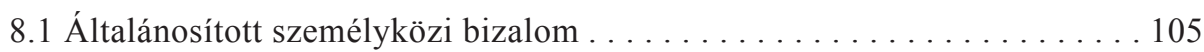

8.2 Intézményekbe vetett bizalom . . . . . . . . . . . . . . . . 109

8.2.1 Többdimenziós skálázás az intézményekbe vetett bizalom változóira . . 112

8.2 .2 Közép-magyarország . . . . . . . . . . . . . . . . . . . 114

8.2 .3 Nyugat-dunántúl . . . . . . . . . . . . . . . . . . . . . . . . . . . . . . . . . . . . . . . . . . . . . . . . . .

8.2 .4 Közép-dunántúl . . . . . . . . . . . . . . . . . . . . . . . . . . . . . . . . . . . . . . . . . . . . . .

8.2 .5 Dél-dunántúl . . . . . . . . . . . . . . . . . . . . . . 117

8.2 .6 Észak-magyarország . . . . . . . . . . . . . . . . . . 118

8.2 .7 Észak-alföld. . . . . . . . . . . . . . . . . . . . . . . . . . . 119

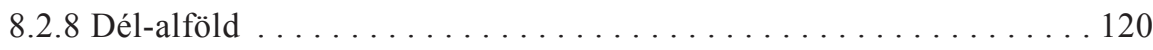

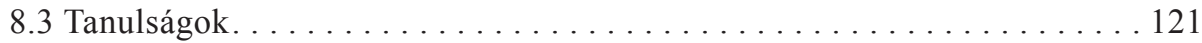

9. A TERÜLETI KÖTÖDÉSEK ELEMZÉSE A NEMZETI ÉS A REGIONÁLIS TERÜLETI SZINTEKEN . . . . . . . . . . . . . . . . . . . . . . . 122

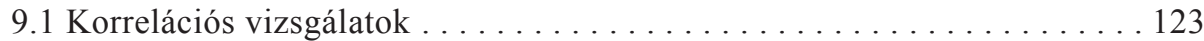

9.2 Kereszttábla elemzések . . . . . . . . . . . . . . . . 125 
9.3 A területi kötődést mérő változók és az általuk alkotott skála tesztelése. . . 127

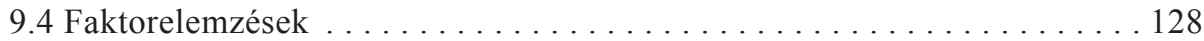

9.5 Kötődés a területi szintekhez . . . . . . . . . . . . . . . . . . . . . . 129

9.5.1 Település . . . . . . . . . . . . . . . . . . . . . . . . . . . . . . . . . . . 129

9.5 .2 Régió . . . . . . . . . . . . . . . . . . . . . . 130

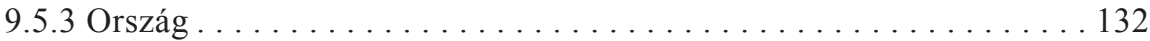

9.5 .4 Európa . . . . . . . . . . . . . . . . . . . . . . . . . . 133

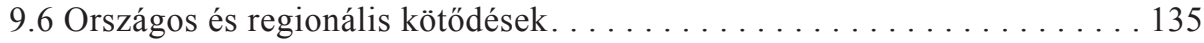

9.6 .1 Országos adatok. . . . . . . . . . . . . . . . . . . . 135

9.6.2 Közép-magyarország . . . . . . . . . . . . . . . . . . . . . . 136

9.6 .3 Észak-magyarország . . . . . . . . . . . . . . . . . . . . . 137

9.6 .4 Észak-alföld. . . . . . . . . . . . . . . . . . . . . . . . . . . . . . . . . . . . . . . . . . . . . . . . . . . . . . .

9.6 .5 Dél-alföld . . . . . . . . . . . . . . . . . . . . . . . . 139

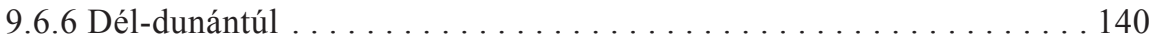

9.6.7 Közép-dunántúl . . . . . . . . . . . . . . . . . . . . . . . . . . . . . . . . . . . . . 141

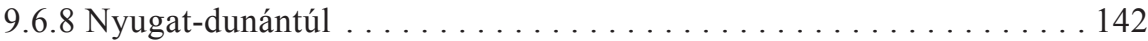

9.7 Tanulságok. . . . . . . . . . . . . . . . . . . . . 143

10. TERÜLETI KÖTŐDÉS A NAGYVÁROSBAN: EGY ESETTANULMÁNY

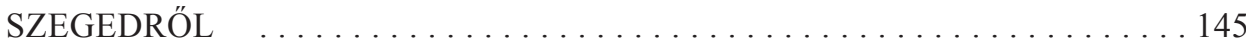

10.1 Területi kötődés és identitás . . . . . . . . . . . . . . . . . . 146

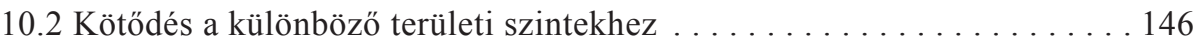

10.3 Faktorelemzés az öt kötődést vizsgáló változóra . . . . . . . . . . . . 148

10.4 Klaszterelemzés a megyei és regionális kötődés változóira . . . . . . . . 146

10.5 Megyei és regionális kötődés demográfiai bontásban . . . . . . . . . 150

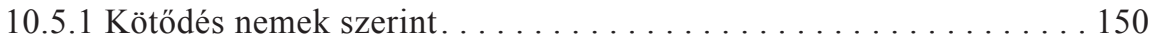

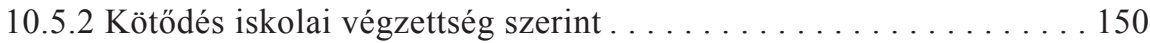

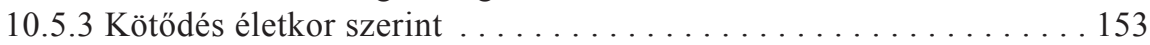

10.5.4 Ordinális korreláció a két változó között . . . . . . . . . . . . 154

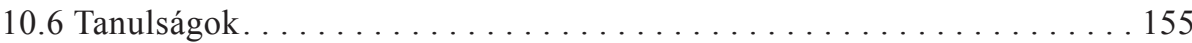

11. A TÁRSADALMI TŐKE ÉS A VALLÁS -ESETTANULMÁNY . . . . . . . 156

11.1 Vallási közösségek konfliktusai a pluralizmus koráig . . . . . . . . . 158

11.2 Vallási közösségek tudományos tipologizálása. . . . . . . . . . . . 160

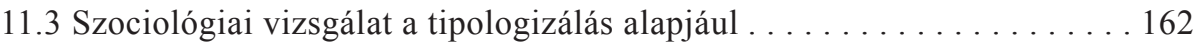

11.4 Új utak a vallási közösségek tipologizálásában . . . . . . . . . . . . . . . . . . . . . . . . . . . . .

11.5 James S. Coleman a vallás és társadalmi tőke viszonyáról . . . . . . . . . 168

11.6 Robert D. Putnam a vallásról és társadalmi tőkéről . . . . . . . . . . . . 169

11.7 Robert Bellah és a vallás jelentősége az amerikai életformában . . . . . . 170

11.8 Andrew Greeley kritikája - vissza a kompakt hálózatok elméletéhez. . . . 171

11.9 Fókuszban a vallási társadalmi tőke . . . . . . . . . . . . . 172

11.10 Társadalmi tőke és valláskutatás magyarországon . . . . . . . . . 175

11.11 Egy kísérlet a vallási társadalmi tőke modellezésére . . . . . . . . . 176

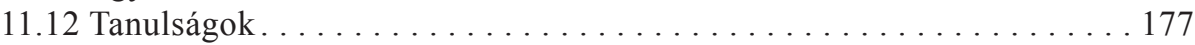

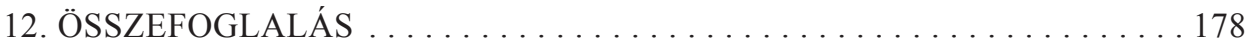




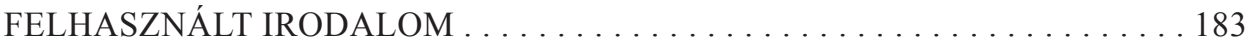

ÁBRAJEGYZÉKK . . . . . . . . . . . . . . . . . . . . . . . . 194

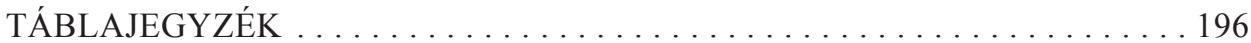

FELHASZNÁLT ADATBÁZISOK JEGYZÉKE . . . . . . . . . . . . . . . . . 197 


\section{HAZAJÁRÓK - ELŐSZÓ HELYETT}

Régi, a középkorban megalapozott hagyománya az egyetemek világának, hogy a tehetséggel és szorgalommal építkező hallgató tanulmányainak, kutatásainak további irányát doktori dolgozatában alapozza meg, publikálásával pedig tudományos eredményeit a szakma szükebb körén túl, a nagy nyilvánosság előtt is mérlegre teszi. Hazai viszonyok között is többé kevésbé és hellyel közel tovább élt ez a jó szokás, viszont tudományterületenként változó gyakorisággal, tehát nem mondható folyamatosnak, így az esemény emelkedettsége is veszített ívéböl. Anélkül, hogy ennek okait firtatnánk, a szociológia egykori szegedi tédékásainak köréből kikerült, ma már az ország egyetemein oktató-kutató fiatal kollégák, a „hazajárók” körében évekkel korábban már felvetődött az a gondolat, hogy a doktori disszertációk könyvformába is jelenjenek meg. A kínálkozó intézményes lehetőségek közül erre az MTA Szegedi Területi Bizottsága keretében 1997-ben alapított Szociológia Munkabizottságot tekintettük alkalmasnak. Az okok közül, az „otthonosságot” hangsúlyozhatjuk, ugyanis számos hazai és nemzetközi rendezvénynek, mühelybeszélgetésnek, könyvbemutatónak stb., az évek során a fiatal kollégák voltak a kezdeményezői, szervezői, így nekik köszönhetően a Szociológia Munkabizottság müködése bensőségessé, a tudományos események „megszokott” keretévé vált. A szokások és szertartások kialakult rendjében új és felemelő esemény a doktori disszertációk könyvsorozatának elindítása, a sorozat első kötetének szerzője Nagy Gábor Dániel. Azonban nyomban hozzá kell tennünk, hogy nem elsőkötetes szerzőről van szó. Tudományos munkássága: tanulmánykötetek, tanulmányok tucatja, társszerzős monográfiák magyar és angol nyelven, melyek itthon és külföldön jelentek meg, valamint tudományszervezői, tudományos eredmények alkalmazása, nemzetközi oktatói-tudományos tapasztalata és kapcsolathálója, konferenciák sora mind az jelzik, hogy a doktori disszertációja egy hosszabb, tudatos, következetés alapozás eredménye. Ha munkásságának ebből a perspektívájából nézzük, akkor nem véletlen a disszertáció/monográfia 
témaválasztása. Nagy Gábor Dániel tapasztalatai tudományos kutatásai, útjai során, láthatóan, a több dimenziós beállítódás mentén formálódtak. A lokális, regionális beágyazása a tágabb országos és európai kontextusokba, a párhuzamosságok és a különbözőségek egymásmellé rendezése, az ütközések csomópontjai, a változások társadalmi tőke és identitás relációjában való vizsgálata, a rokon tudományok eredményeinek alkalmazásmódja letisztult, újszerü megközelítése „A társadalmi töke és területi kötödés a magyar régiókba" címü, immár kötetbe foglalt monográfiának nagy erényei. Ami szemléleti nyitottsággal, az elméleti és metodológiai vonulatok alkalmazásának jól ítélő képességével párosul. Nem lehet célunk és nem illendő Nagy Gábor Dániel monográfiájának/disszertációjának részletező értékelése hiszen ezt már nálunk kompetensebb szakemberek megtették a pécsi Interdiszciplináris Doktori Iskola keretében lezajlott eljárás során, csupán néhány szóban jó benyomásunknak adtunk hangot. Nem is a szakmai értékeléstől elrugaszkodva, hiszen Pálné Dr Kovács Ilona akadémikus, a disszertáció témavezetője, annak idején (2011), más terminusokban hasonlókat fogalmazott meg. A kellemes feladatunk a szerző úttörö, sorozat indító monográfiájával, egyébként sem lehet más, mint a siker és folytatás reményében, az utána következő „hazajáróknak” is emlékezetébe idézzük, a tudomány kötelez, szorgalmat, példaadást igényel, mert mindig- mindig utánunk is mások jönnek.

Pászka Imre 


\section{BEVEZETŐ MEGFONTOLÁSOK}

Jelen könyvben célom a regionális összehasonlítások elvégzése a NUTS ${ }^{1} 2$-es szintủ magyar régiók esetében, a különbségek feltérképezése érdekében. Eszközöm a különböző térségi sajátosságok és adottságok megismerése és összevetése tudományos vizsgálódás és kutatás által. A különböző térségek eltérő arculatát többféle elméleti koncepció felhasználásával vetem össze. Ezen tudományos összevetést megalapozandó elöször arra a kérdésre térek ki, ami nyilvánvaló mindenki számára: a magyar régiók eltérő és hasonló tulajdonságokkal egyaránt rendelkeznek. Eltérő például a földrajzi helyzetük, eltérőek domborzati viszonyaik. Jelentős eltérés tapasztalható a gazdasági berendezkedésükben: a térségek GDP-jében és aktivitási arányszámaiban, a működő vállalkozások számában és a külföldi befektetések mértékében. Eltérőek a térségek néprajzi szempontból, hagyományok és népi kultúra szempontjából.

Ugyanígy megállapíthatjuk a hasonlóságokat is: az intézményrendszer minden közigazgatási régióban azonos szerkezetü, abban nem találunk köztük eltérést. A tartalma ezeknek az intézményrendszereknek azonban kutatásokkal is igazolható módon különböző, müködésüket társadalmi környezetük nagyban befolyásolja (Vö. Pálné 2005). A regionális nyelvi és etnikai homogenitás Magyarország homogén nemzetállam (Brunner 1995) voltának tudható be, és minden régió esetében hasonló képet mutat. A köznyelv erős meghatározó jellege mellett azonban jelentős régiós jelegü nyelvjárások is fellelhetőek.

A régiók tehát a különböző összehasonlítási szempontok mentén igen vegyes képet mutatnak. A célom, hogy az összehasonlítási szempontok közül kiemelve elsősorban a régiók helyi társadalmait vizsgáljam, és a különböző régiók lakosságának véleménye alapján feltérképezzem az eltéréseket és különbözőségeket.

\footnotetext{
${ }^{1}$ Nomenclature of Territorial Units for Statistics; http://ec.europa.eu/eurostat/ramon/nuts/home regions_en.html
} 
Meg kívánom vizsgálni az eltérő térségi arculat hatásait az ott élő emberekre, illetve az ott élö emberek és társadalmi hálózatok hatásait a térségi arculatokra. Hiszen elmondható, hogy a térség is formálja az embert, és az ember is formálja a térséget, annak múködését, adottságait és profilját. Meggyőződésem szerint a magyar NUTS 2-es régiók olyan helyi társadalmakkal rendelkeznek, amelyek több tekintetben hasonlítanak a teljes társadalomhoz, ám sok tekintetben különböznek is attól. A különbözőségek jelen esetben lényegesen érdekesebbnek tünnek, hiszen azokból olyan jellegü empirikus tapasztalatokat lehet levonni, amelyek az egyes térségek számára készülő tervezésben is nagymértékben hasznosíthatóak.

Kutatásomat nagy mértékben inspirálta Robert D. Putnam és kollégái (1993) könyve, mely az enyémhez hasonló felvetést fogalmazott meg Olaszország régióival kapcsolatban. Putnam és kollégái azonban a regionális önkormányzatok müködését és azok sikerességét vizsgálták, nem pedig a lakosság véleményét és a helyi társadalom realitásait. Ennek ellenére írásom szempontjából kiemelkedő fontosságú momentum az az eredmény, miszerint a nagyon hasonló földrajzi és gazdasági paraméterekkel rendelkező térségek regionális önkormányzatai nagyon különbözö teljesítményt tudnak nyújtani, a szerzők következtetése szerint helyi társadalmuk és társadalmi hálózataik sajátosságai miatt.

A helyi társadalmak analitikus megismerésén túl kutatási érdeklődésem középpontjában áll továbbá az egyes térségek ,sikerességét” meghatározó tényezők vizsgálata. Az egyik ilyen tényező pedig az olasz példa alapján is egyértelmúen a térség lakosságának hálózatokba szerveződése, és ezen hálózatok működése. A különböző ügyekhez és elgondolásokhoz való viszonyulásaik, kooperációs képességük, a közbizalom és a szolidaritás szintje egyaránt kiváló indikátorok lehetnek a térségek teljesítményében. Mivel a munka a társadalomtudomány eszköztárával operál, ezért egy társadalomtudományi fogalmat szeretnék bevezetni, mely komplex indikátorként lehet alkalmazható e cél elérésében. Putnam és kollégái (1993) is, és Kearns és Forrest (2000) is a társadalmi kohézió mértékét ajánlja ilyen indikátorként, amely megmutatja az adott térségi társadalom állapotát, többdimenziós elméleti alrendszer alkalmazása segítségével.

A következőkben bemutatom kutatásom eredményeit, melyben két igen népszerü gyüjtőelméletet, a társadalmi tőke és a területi identitás elméleteket használtam fel vizsgálódásaim alapjaként, empirikus elemzéseim kereteként. Kearns és Forrest $(2000,2001)$ a két elméletet a társadalmi kohézió fontos meghatározó jellemzőiként kezeli városi térségekben végzett vizsgálódásaik alapján. Az én kutatásom célja is a különböző magyar régiók helyi társadalmainak vizsgálata a társadalmi integráció és kohézió szempontjából. A társadalmi tőke és a területi 
identitás elmélet egymáshoz való viszonya szempontjából feltételeztem, hogy elemeik között erős összefüggés tapasztalható, kiváltképp a társadalmi élet különböző dimenzióira vonatkozó elméleti részek esetében. Közös eleme mindkét elméletnek a társadalmi integráció, illetve kohézió szintjének jelzése, az azokkal való erős, determináló összekapcsoltság. A társadalmi integráció, illetve a társadalmi kohézió mutatja meg a vizsgált társadalom ,együttműködési képességét”, illetve jelzi a társadalom „egészségességének” fokát, ezért mindkét jellemző minél jelentősebb volta egyaránt kívánatosnak tekinthető. A kutatás jelentőségét az a tény adja, hogy a társadalmi kohézió és integráció erősítése minden demokratikus politikai berendezkedésü rendszer esetén fontos célként merül fel. A modern társadalomtudományi vizsgálódás célja sok esetben az, hogy megismerhessük, különböző jelenségek milyen hatással vannak a társadalmi integrációra, az adott társadalom kohéziójára.

Fontos példaként említhető meg, hogy napjainkban az Európai Unió prioritást élvező célja a területi-társadalmi integráció és kohézió regionális és európai szinten történő erősítése, a közösség egységének megszilárdítása érdekében. Az unió országaiban a politikai decentralizáció és a területi identitás megerősítése és újraértelmezése az európaizáció folyamatán keresztül zajlott le, illetve zajlik napjainkban is. Az EU szándéka és szerepe vitathatatlan a különböző területi szintjein zajló folyamatok befolyásolásában. A területi identitás erősítésének célja, hogy élettel teli, jól müködő helyi társadalmak létrejöttét segítse elő az adott területi szinteken. A társadalmi tőke szintjének növelésével kapcsolatos, az Európai Unió által támogatott programok céljai hasonlóak: szinte minden esetben a társadalmi integráció erősítése és a kohézió növelése a terv.

Másik fontos példaként szolgál az Egyesült Államok, a társadalmi tőke elmélet bölcsője, illetve a helyi és regionális identitással kapcsolatos vizsgálódások fontos színtere. A regionális fejlesztésben az Egyesült Államokban a közösségi tervezés során figyelembe veszik a területi identitás és társadalmi tőke szintjét jelző kutatásokat, mint a társadalmi integráció fokának jelzésére alkalmas indikátorokat. A vonatkozó társadalomtudományi kutatások eredményei alapján indítanak szakpolitikai programokat a társadalmi integráció erősítése céljából. Mivel az államok autonómiát élveznek a helyi fejlesztésekkel kapcsolatban az USA-ban, így sokféle közösségi kezdeményezés és program fut egymással párhuzamosan az országban, mind különböző eszközrendszerrel és háttérrel, ám azonos célrendszerrel.

A két elmélet gyakorlati implementációjára tett kísérletek fontos felismerésekből fakadnak. Az Európai Unióban az újonnan csatlakozott országok estében a cél az európai integráció elmélyítése, az európai összetartozás-érzés és identitás erősítése. A régi EU tagok esetében az EU-n belülről és kívülről indult migráció 
társadalmi hatásait kívánják az elgondolások gyakorlati alkalmazásának segítségével kezelni. A területi identitás és társadalmi tőke erősítésének szándéka mögött fontos elem továbbá a nacionalizmus és euro-szkepticizmus kezelésének, visszaszorításának reménye a régi és új tagállamok esetében egyaránt. A társadalmi integráció erősítésének és a társadalmi kohézió növelésének szándéka természetesen visszavezethető az Európai Unió megjelenése előtti, nemzetállami közigazgatási és politikai színtérre is.

Az Egyesült Államokban a célok leginkább a politikai részvétel növelése, az elmaradott, rurális régiók fejlesztése, a nagyvárosi és elővárosi szomszédságok revitalizálása és a társadalmi élet felpezsdítése szempontjából értelmezhetőek. A társadalmi tőke egyik legjelentősebb teoretikusa, Robert D. Putnam (2000) egyenesen az amerikai civil társadalom végét vizionálta és a meredeken eső politikai részvételt vetítette elő „Bowling Alone” című művében. Később a szerző maga állt a társadalmi élet revitalizációját, és a társadalmi kohézió és integráció növelését célul kitüző kezdeményezés, a „The Saguaro Seminar - a Saguaro Szeminárium” élére.

Jelen mủvemben én a fent említett, globális példák felismeréseiből kiindulva kifejezetten az európai integráció, illetve az Európai Unió kohéziós politikája által előidézett, valamint a magyar regionális reformok és fejlesztéspolitikai rendszer eredményeképpen kialakult hatásokat tervezem vizsgálni a hazai NUTS 2-es régiók helyi társadalmainak szintjén.

A vizsgálat részleges célja többek között az is, hogy felmérjem a regionális reformok és az EU csatlakozás hatásait a magyar társadalomra, illetve a régiók helyi társadalmaira. A regionalizmus és a regionalizáció különbsége Magyarországon is megmutatkozik, mivel a hazai példa nagy részében a „top-down” (felülről jövő) régiószervezésre korlátozódik, a „bottom-up” (alulról jövő) jellegü kezdeményezések ritkák a régiós szint esetében. A régiókhoz való identifikálódás illetve kötődés ezért evvel a korlátozással értelmezendő. Az ilyen formában létrejött régiókhoz, Európai Unióhoz való kötődések mellett meg kívánom vizsgálni a konvencionális, „bevett” területi egységekhez (város, megye, ország) való lakossági kötődést is.

Elmondható, hogy a két felhasznált elmélet kapcsolata változó mértékben reflektált. Konkrétan a társadalmi tőke elmélet és a területi identitás elmélet kapcsolatát célzó nemzetközi vagy magyar vizsgálódások nem állnak rendelkezésre, habár egyes kutatók ténylegesen foglalkoznak a kérdéssel, illetve annak határterületeivel. Megjelent például a területi tőke fogalma, melyet az Európai Unió Harmadik Kohéziós Jelentése tett ismertté széles körben. A fogalom fontos szakszóvá vált az 
Európai Uniós fejlesztéspolitikában, valamint a régiókkal és regionalizmussal foglalkozó kutatók (Vö: Putnam 1993; Lengyel 2003; Camagni 2009) is használják azt elemzéseikben, hazánkban és külföldön egyaránt.

A társadalmi tőke és a területi kötődés elméletek együtt kerülnek elő Kearns és Forrest $(2000,2001)$ munkáiban. A cikkre alapozva több térségi kohéziót vizsgáló tanulmány (Vö. Stanley 2003) is követi a példát, és egy nagyobb térségi kohézió elemeiként jelölik meg a társadalmi tőkét és a területi kötődést. Elgondolásom szerint a területi tőke és a térségi kohézió elméletek érdekes kapcsolódási pontokat vetnek fel jelen munka szempontjából. Kutatási eredményeim és tapasztalataim szerint a területi kohézió és a területi tőke elméletek legnagyobb problémája azonban a „látens” elméleti jellegük, mely nagymértékben megnehezíti pontos konceptualizálásukat, és az elméleti tisztázás mentén a mérésre operacionalizálásukat. Éppen ezért az említett munkákat komoly igazoló tényezőként értékeltem saját munkám szempontjából, hiszen az általam alkalmazott elméleti koncepciók kapcsolódásait az ezekkel kapcsolatos tudományos diskurzus fényesen visszaigazolta. Azt is alátámasztva látom továbbá, hogy én magam nem tértem át a területi tőke és a területi kohézió elméleti koncepcióknak a használatára, mivel célom empirikus vizsgálódások végzése és a konkrét térségek összehasonlítása. Ennek érdekében pedig mindenképpen a könnyebben konceptualizálható és operacionalizálható elméleteket kellett választanom.

Elemzéseimben megpróbálok releváns, a társadalmi tőke és a területi kötődés elméleteket összekötő reflexiókról számot adni, saját eredményeim és elgondolásaim tálalása mellett. Az elméleti részben az elméleteket vizsgálom, először különkülön, majd összevetem a két elméletet, és igyekszem azonosítani a köztük lévő kapcsolatokat, valamint eltéréseket. A területi identitás egyik fontos, és leginkább mérésre operacionalizálható elemét, a területi kötődést meg kívánom vizsgálni abból a szempontból, hogy milyen szerepet játszik a társadalmi tőkében, esetleg tekinthető-e a területi elemzések végzésekor a társadalmi tőke egy megnyilvánulásának. Jelen írásom témájához kapcsolódóan meg kell jegyezni, hogy arra vonatkozóan kevés hazai vizsgálat készült, ezek közül néhány kiemelendő (Vö: Bugovics 2007, Lengyel 2003, Pálné 2000 és 2009, Rechnitzer 1998 és 2004). 


\section{MÓDSZERTANI ALAPOK}

Írásom empirikus részében két nagymintás kérdőíves kutatás, az Eurobarometer és az Európai Társadalomtudományi Elemzések (European Social Survey) különböző hullámainak adatbázisai alapján elvégzett statisztikai másodelemzéseimet ismertetem, Magyarországra vonatkozó országos, illetve regionális bontásban. Ezen munka alapvető elemzési egységei a NUTS 2-es szintre besorolt magyar régiók, melyeknek különbségeiről és hasonlóságairól összehasonlító elemzést végeztem a területi kötődés és a társadalmi tőke, illetve azok összefüggéseinek vonatkozásában. A kutatás empirikus részében is választ keresek arra a kérdésre, hogy helyesebb-e a területi identitást, operacionalizálva a területi kötődést a társadalmi tőke elmélet részeként kezelni, vagy pedig érdemes elindulni egy új elméleti konstrukció, a területi tőke vagy társadalmi integráció vagy kohézió konceptualizálásának és vizsgálatának irányába, melynek a területi idenitás-kötődés és a társadalmi tőke feltételezhetően része lesz.

Módszerként használom még a konfirmációs faktorelemzés módszerét, melynek segítségével a mérési invariancia meglévő típusát kívánom megállapítani a nagymintás vizsgálatok regionális adatbázisain. Az invariancia jelenti az adatok egyféle skálán történő értelmezhetőségét a különböző vizsgált térségek esetében. Azt leginkább a térségek helyi társadalmainak válaszai befolyásolhatják. Megléte azt jelentené, hogy a térségek társadalmai az általam vizsgált kérdések tekintetében nem különböznek egymástól. Hiánya azt jelenti, hogy a különböző térségek esetében, hogy a lakosság azonos szöveg és válaszlehetőségek mellett sem ugyanazt érti ugyanazokon a kérdéseken. Az invariancia tesztelést leginkább fordítások sikerét bizonyítandó szokták alkalmazni a társadalomtudományi vizsgálódásban: azaz az összes szövegvariáns azonos jelentését alátámasztandó. Jelen esetben kézenfekvőnek tünik alkalmazása a különböző régiók helyi társadalmainak összehasonlítására. 
Befejezésképpen pedig az esettanulmány készítés módszerét alkalmazom. Az esettanulmányok nem kapcsolódnak szervesen munkám fö empirikus kutatási kérdéséhez, mivel nem regionális adatbázisok elemzésén alapulnak. Kapcsolódnak azonban annak témájához, a társadalmi tőke elmélet és a területi identitás és kötődés elmélet valamint kapcsolódásaik elméleti és nem regionális léptékủ empirikus feltárásához. Az első esettanulmányban egy a Szeged Studies - szegedi nagyvárosi kutatás adatbázisa alapján veszem górcső alá a területi kötődés kérdését, és teszek a téma szempontjából releváns megfogalmazásokat. A második esettanulmányban a vallási társadalmi tőke elméleti koncepcióját mutatom be, valamin annak alkalmazási lehetőségeit a vallási közösségek tipizálásában, a közösségek tagságának véleménye alapján. Így helyezem szélesebb kontextusba a hazánkban amúgy nem meghatározó vallási társadalmi tőke dimenziót, mint a különböző vallási közösségek tipizálásának új és a régi módszernél tartalmasabb eredményeket kínáló eszközét.

\subsection{A STANDARD EUROBAROMETER NEMZETKÖZI ÖSSZEHASONLÍTÓ KÉRDŐÍVES KUTATÁS MÓDSZERTANI SZEMPONTÚ BEMUTATÁSA}

A nemzetközi kutatások közül ezen írás célja szempontjából az Eurobarometer kérdőíves vizsgálat több szempontból is kiemelkedik. A segítségével lehetséges a megkérdezettek helyekhez, illetve területi egységekhez kötődő azonosulását, helyi, illetve területi identitását regionális mintákon kutatni. A Standard Eurobarometer vizsgálat évente, van, amikor évente többször mér területi kötődéssel és identifikálódással kapcsolatos kérdéseket 1991 óta. A kérdőíves kutatás extenzív longitudinális jellege kiemelt fontosságú az adatok idősoros értelmezésének lehetősége szempontjából.

Az Eurobarometer felmérés egy nemzetközi és longitudinális komparatív társadalomtudományi kutatássorozat, melyet az European Opinion Research Group végez el, egy olyan konzorcium, amelyet piac- és közvélemény-kutató cégek hívtak életre. A lekérdezésekre a megrendeléseket az Európai Bizottság Sajtó és Kommunikációs Főigazgatóság Véleménykutató részlege (Directorate-General Press and Communication, Opinion Polls) adja le. Az adatok a Kölnben lévő Zentral Archiv kezelésében érhetőek el a tudományos közönség számára.

Az Eurobarometer kérdőíves kutatás az Európai Unió tagállamainak polgárai körében készül, bekerülhet minden 15 évnél idősebb állandó lakos bármely tagállamban, függetlenül az eredeti állampolgárságától. A minta, amelyen az Eurobarometer 
adatfelvétele alapul, egy többlépcsős, véletlen (valószínúségi) minta. A megfigyelési egységek az egyének. Minden egyes tagállamban mintavételi helyeket választanak, a lakosságszám nagysága által reprezentált valószínúséggel, tekintetbe véve a népsürüséget. Ezen szempontok figyelembevétele mellett a cél az ország teljes lefedettségének az elérése. A mintavételi pontokat a „közigazgatási regionális egységekből" választják ki szisztematikus módszerrel, a terület adottságainak megfelelö rétegzési eljárás lefolytatása után. Ezen eljárás ismeretének a fényében elmondható, hogy a kiválasztott minták jól reprezentálják az EU tagállamokat, és mivel a mintavételi pontok kiválasztása az Eurostat NUTS II szinten történik, a minták regionális szinten is reprezentatívnak tekinthetőek. A mintaválasztás tekintettel van a népesség eloszlására, a nemzetiségek jelenlétére és a nagyvárosi, városi és vidéki térségek arányára is. Az új tagállamok állampolgárai először 2004-ben kerültek be a Standard Eurobarometer hullámba (ICPSR, 2005).

A mintanagyság a tagállamok esetében általában 1000 fős, illetve kicsivel e szám feletti vagy alatti. E szám eltérő Észak-Írország és Luxemburg esetében, nagyjából 300 és 600 fö között mozog. Az adatfelvételeket minden esetben elismert kutatóintézetek vezető kutatóinak felügyelete mellett dolgozó, képzett kérdezőbiztosok hajtják végre, szigorú ellenőrzések mellett. Ezer megkérdezett válaszait tartalmazó mintával számolva, az egyes változók eloszlását figyelembe véve a kutatás megbízhatósága az alábbi konfidencia intervallumokban mozog:

\section{1. tábla - Eurobarometer konfidencia intervallumok}

\begin{tabular}{|l|c|c|c|c|c|}
\hline $\begin{array}{l}\text { Mintában } \\
\text { megfigyelt } \\
\text { százalék }\end{array}$ & $\begin{array}{l}\mathbf{1 0} \% \\
\text { vagy } \\
\mathbf{9 0 \%}\end{array}$ & $\begin{array}{l}\mathbf{2 0} \% \\
\text { vagy }\end{array}$ & $\begin{array}{l}\mathbf{3 0} \% \\
\text { vagy }\end{array}$ & $\begin{array}{l}\mathbf{4 0 \%} \\
\text { vagy } \\
\mathbf{6 0 \%}\end{array}$ & $\mathbf{5 0 \%}$ \\
\hline $\begin{array}{l}\text { Konfidencia } \\
\text { határok }\end{array}$ & $\pm 1,9 \%$ & $\pm 2,5 \%$ & $\pm 2,7 \%$ & $\pm 3,0 \%$ & $\pm 3,1 \%$ \\
\hline
\end{tabular}

\subsection{AZ EURÓPAI TÁRSADALOMTUDOMÁNYI ELEMZÉSEK (ESS) MÓDSZERTANI SZEMPONTÚ BEMUTATÁSA}

Az Európai Társadalomtudományi Elemzések nemzetközi összehasonlító kutatás ezen írásomban felhasznált harmadik sorozatának felvételét a Magyar Gallup Intézet készítette és szervezte. A következőkben e harmadik, 2006-2007-ben zajlott adatfelvételi hullám módszertanát ismertetem a hivatalos módszertani leírás alapján (EUTE é.n.). 
A minta összeállítása szempontjából elmondható, hogy a kutatást országos, 15 éves és ennél idősebb polgárok mintáján végzik. Ez az országos minta a Magyarországon élő 15 éves és idősebb magyar népességet reprezentálja az alábbi dimenziók szerint: • nem; • életkor; • iskolai végzettség; • településtípus és • régió. A minta tehát a felsorolt dimenziók szerint reprezentatív, valószínüségi minta, ami többlépcsős, arányosan rétegzett kiválasztással készült. A harmadik felvétel idején a minta kiválasztásánál háztartási címlistából indultak ki a kutatók. A mintanagyságról elmondható, hogy csökkenő mintavételi módszerrel zajlott az adatfelvétel, és összesen 1518 sikeres interjú készült el. A vizsgálat lakossági mintája háromlépcsős véletlen mintavétel során került elkészítésre. A kutatást standardizált kérdőívvel, a kérdezett lakásán történő, a személyes kérdőíves interjú módszerével folytatták le a Magyar Gallup Intézet kérdezőbiztosai (EUTE é.n). Vizsgálódásom szempontjából a kutatás legfontosabb jellemzője, hogy az EUROBARMETER kutatáshoz hasonlóan az EUTE/ESS vizsgálat adatai is regionális szempontból reprezentatív adatok, és a nagyobb elemszám miatt pontosabb regionális összehasonlítások elvégzésére adnak lehetőséget.

\subsection{SZEGED STUDIES 2004 KUTATÁS BEMUTATÁSA}

A felhasznált adatfájl, egy szegedi kérdőíves adatfelvétel, a Szeged Studies 2004 tavasz eredménye. A kutatást a Szegedi Tudományegyetem Szociológia Tanszéke végezte 2004. március-áprilisban, mely intézmény 2000 októberétől évente végez adatfelvételeket a szegedi lakosság körében. A kutatás mintavételi módszere a csökkenő mintás mintavétel, melynek segítségével az „induló” minta kb. 55\%-ára lehet számítani, kb. 5\% türéshatárral. A tanszék a címeket a legnaprakészebb forrásból, a Központi Nyilvántartó és Választási Hivataltól veszi. Statisztikai elemzéseinkben az adatbázist négy dimenzióban súlyozott formában használjuk fel.

\subsection{INVARIANCIA MÉRÉS KONFIRMÁCIÓS FAKTORELEMZÉS SEGÍTSÉGÉVEL}

Az összehasonlíthatóság fokát az elemzéseinkben vizsgált és felhasznált változók esetében az elért invariancia típus határozza meg. Az invariancia vizsgálata segít nekünk megállapítani, hogy a különböző mért változók ugyanazokat a látens változókat 
és struktúrákat adják-e ki a vizsgálati csoportok összességében. Azt teszteljük az invariancia meglétét vizsgáló modelljeinkben, hogy ugyanazt az elméletet (látens változót, faktort) mértük-e meg a különböző regionális helyi társadalmak esetében, ugyanazon változók segítségével.

Az invariancia első szintje az ún. konfigurális invariancia. Ezen típus létrejöttének feltétele csupán annyi, hogy az egyes mért változók ugyanazt a látens változót mérjék minden csoportban. (Füstös, Kovács et al. 2004; Chen 2007)

Az invariancia második szintje a mért változók által meghatározott látens faktorok faktorsúlyának mértékével foglalkozik. Ezt az invariancia szintet nevezzük metrikus invarianciának, és megléte lehetővé teszi az adatok korrelációinak összehasonlítását (Byrne 2004; Chen 2007).

Az invariancia harmadik szintjét skálás invarianciának nevezzük, mely előfeltétel a vizsgált csoportok átlagainak összehasonlíthatóságához. Ez a legmagasabb szintü invariancia. (Byrne 2004; Chen 2007).

Barbara M. Byrne beszél továbbá parciális invarianciáról, amelynek megléte esetén nem az egész modell átlagai hasonlíthatóak össze, csupán azoknak a részeknek az átlagai, amelyeket külön leteszteltünk ebből a szempontból. A gyakorlati tapasztalatok szerint az invarianciának ezen formája fordul elő a leggyakrabban (Byrne 2001; Byrne 2004).

Az invariancia mérését SPSS Amos programmal, konfirmációs modellek segítségével végeztük el. Az invariancia típusokat a modell részletes bemutatásánál tárgyaljuk alaposabban. A mérési modell empirikus haszna ebben az esetben az, hogy rámutathat arra, hogy vannak-e eltérések a különböző helyi társadalmak között a vizsgált változók tekintetében. Amennyiben nem találunk legmagasabb szintü invarianciát, úgy az már maga egy tudományos eredmény, és egyedi térségi arculatról árulkodik.

\subsection{AZ ESETTANULMÁNY MÓDSZERE}

Az esettanulmányok tudományos értékét sok kutató kevesebbnek tartja, mint a komparatív kutatási eredmények tudományos hasznát. Bradshaw és Wallace ezzel a véleménnyel szemben amellett érvel, hogy az esettanulmányok az összehasonlító kutatás egy fontos fajtáját jelentik, és néhány kutatási téma esetében ezen módszer alkalmazása nélkül nem juthatnánk értelmes eredményekhez. Véleményük szerint az esettanulmány akkor lehet hasznos, ha a kutatók nem rendelkeznek elég ismerettel az esetről az elméleti perspektívába helyezéshez, vagy pedig ha az eset 
nem fér bele egyetlen fennálló elméletbe sem. Előfordulhat továbbá, hogy egy eset csak részlegesen fér bele egy létező elméletbe, illetve, hogy az eset olyan speciális körülményeket képvisel, ami intenzív tanulmányozást követel meg (BradshawWallace 1991, 154-155 o.).

Bradshaw és Wallace véleményét osztom, miszerint az esettanulmányok egyenrangú, fontos részei az összehasonlító kutatásnak. Az esettanulmányok sok esetben nem nélkülözik az elméleti megalapozottságot. Az átfogó elméletek jó próbái ezek, melyek segíthetnek speciális esetekre szabni a jelentős teóriákat (BradshawWallace 1991, 155 o.). Fontos megemlíteni azonban, hogy például antropológiai megközelítésű vizsgálatok esetében az esettanulmányok értéke mindenképpen megnő, kiemelt jelentőségüvé válik.

\subsection{MÓDSZERTANI ÖSSZEFOGLALÓ}

Tapasztalataim szerint a módszerek használatának megválasztási lehetőségét behatárolják a kutatott téma és a kutató rendelkezésére álló lehetőségek. Sok esetben a különböző megközelítések egy téma vizsgálatánál történő párhuzamos használatával jobb eredmény érhető el, mintha kizárólag egy megközelítés mellé tennénk le a voksunkat. Ezen munkámban föként másodelemzéseket végzek az ESS/EUTE harmadik hullámának illetve az EUROBAROMETER nemzetközi kutatás 2004 és 2007 közé eső néhány hullámának magyar adatbázisain. E másodelemzések esetében felhasználom a nemzetközi összehasonlító kutatások módszertanát, továbbá kibővítem a különböző kultúrákban felvett adatokra hagyományosan végzett mérési invariancia vizsgálattal az ESS/EUTE adatai felhasználása alapján a magyar régiók esetében. Az invariancia vizsgálatot azért ezen az adatbázison végzem el, mert a magasabb elemszám (az Eurobarometer kutatás általában 1000 fő körüli véletlen mintával dolgozik, míg az ESS/EUTE 1500 fős körülivel hazánk esetében) nagyobb biztonsággal teszi lehetővé az érvényes állítások megfogalmazását.

Emellett azonban elökerül egy nagyvárosi minta (Szeged Studies) mint kutatói forrás elemzése és két vallási közösség mintájának (SZTE BTK Vallástudományi Tanszék „Kultúra és Vallás” Kutatás) elemzése is a felhasznált esettanulmányok keretein belül. 


\section{HIPOTÉZISEIM}

1. A területi kötődés és a társadalmi töke elmélet összekapcsolódnak területi vizsgálódások esetében, így a magyar régiók helyi társadalmait reprezentáló minták esetében is. Azaz a meglévő bizalom, reciprocitás, részvétel, tolerancia és helyi kötődés határozza meg az adott térség társadalmi integráltságát és kohézióját, mely sok más dimenzióra is hatással van. Befolyásolja a gazdasági és a politikai dimenziót, valamint a természeti környezet állapotát is. A területi kötődés és a társadalmi tőke „együtt jár”, egyik a másik szempontjából meghatározónak tekinthetö. A nagyobb egységnek a társadalmi tőke tekinthetö.

2. A társadalmi tőkének és a területi kötődésnek nem alakult még ki konszenzusos értelmezési kerete és tartalma a különböző magyar NUTS 2-es régiók lakosságának vizsgálata esetében. A mérési invariancia eléréshez az operacionalizálást és a konceptualizálást térségenként kellene elvégezni.

3. Feltételezésem szerint minden térségi szint esetében igaz, hogy az adott térségben tapasztalható területi kötődés szint és a térség társadalmi-tőke szintje között egyértelmü összefüggés, elméleti és empirikus együtt járás tapasztalható. Célom, hogy ezen állítást a magyar régiók (NUTS 2) esetében empirikusan is megpróbáljam igazolni.

Az 2. táblázatot a hipotézisek értelmezésének megkönnyítése céljából szerkesztettem. Tartalmazza egyfelől a hipotézis felállítását meghatározó okokat, és az avval kapcsolatban felmerülő okozatokat. Helyet kaptak benne továbbá az ok és az okozat fogalmai, melyeket elemzéseim során használok. 


\section{2. tábla-A hipotézisek konceptualizálása és operacionalizálása}

\begin{tabular}{|c|c|c|c|c|}
\hline \multirow[b]{2}{*}{ Hipotézis } & \multirow[b]{2}{*}{ Ok } & \multirow[b]{2}{*}{ Okozat } & \multicolumn{2}{|c|}{ A fogalmak operacionalizálása } \\
\hline & & & Az ok fogalmai & $\begin{array}{c}\text { Az okozat } \\
\text { ogalmai }\end{array}$ \\
\hline $\begin{array}{l}\text { 1. A területi kötődés a tár- } \\
\text { sadalmi tőke elmélet ösz- } \\
\text { szekapcsolódnak területi } \\
\text { vizsgálódások esetében, } \\
\text { így a magyar régiók helyi } \\
\text { társadalmait reprezentáló } \\
\text { minták esetében. }\end{array}$ & $\begin{array}{l}\text { A területi } \\
\text { kötődés és a } \\
\text { társadalmi töke } \\
\text { egyaránt a tér- } \\
\text { ségi társadalmi } \\
\text { integráció és } \\
\text { kohézió fokát } \\
\text { jelzik. }\end{array}$ & $\begin{array}{l}\text { A társadalmi tőke } \\
\text { kapcsolatba kerül a } \\
\text { területi kötődéssel } \\
\text { az egyes térségi } \\
\text { vizsgálatok végre- } \\
\text { hajtása esetében. }\end{array}$ & $\begin{array}{l}\text { Területi kötődés: } \\
\text { - település } \\
\text { - megye } \\
\text { - régió } \\
\text { - nemzet } \\
\text { - EU } \\
\text { Társadalmi tőke: } \\
\text { - Általánosított } \\
\text { bizalom } \\
\text { - Intézményi } \\
\text { bizalom }\end{array}$ & $\begin{array}{l}\text { Térségi társadalmi } \\
\text { tőke elemei: } \\
\text { - térségi általánosí- } \\
\text { tott bizalom } \\
\text { - térségi intézményi } \\
\text { bizalom } \\
\text { - területi kötődés }\end{array}$ \\
\hline $\begin{array}{l}\text { 2. A társadalmi tőkének } \\
\text { és a területi kötődésnek } \\
\text { nem alakult még ki } \\
\text { konszenzusos értelme- } \\
\text { zése kerete és tartalma } \\
\text { a különböző magyar } \\
\text { NUTS 2-es régiók } \\
\text { lakosságának vizsgá- } \\
\text { lata esetében. A mérési } \\
\text { invariancia eléréshez } \\
\text { az operacionalizálást } \\
\text { és a konceptualizálást } \\
\text { térségenként kellene } \\
\text { elvégezni. }\end{array}$ & $\begin{array}{l}\text { A társadalmi } \\
\text { tőke elméletet } \\
\text { absztrakt és } \\
\text { értelmezési } \\
\text { lehetőségek } \\
\text { szempontjából } \\
\text { tág jellege miatt } \\
\text { nem rendelke- } \\
\text { zik egységes } \\
\text { jelentéstartam- } \\
\text { mal, illetve } \\
\text { az elemeinek } \\
\text { jelentése helyi } \\
\text { társadalmanként } \\
\text { eltérő lehet. }\end{array}$ & $\begin{array}{l}\text { A különböző régi- } \\
\text { ók lakosságai sem } \\
\text { fognak egységes } \\
\text { elgondolással ren- } \\
\text { delkezni a társadal- } \\
\text { mi tőke és a területi } \\
\text { kötődés elemeiről. } \\
\text { Az azt mérő kérdé- } \\
\text { sek esetében nem } \\
\text { fogunk a vizsgált } \\
\text { területi szinteken } \\
\text { mérési invarianciát } \\
\text { találni. }\end{array}$ & $\begin{array}{l}\text { - térségi általánosí- } \\
\text { tott bizalom } \\
\text { - térségi intézmé- } \\
\text { nyi bizalom } \\
\text { - települési kötődés } \\
\text { - megyei kötődés } \\
\text { - regionális kö- } \\
\text { tődés } \\
\text { - nemzeti kötődés } \\
\text { - európai kötődés }\end{array}$ & $\begin{array}{l}\text { Invariancia típusa: } \\
\text { - konfigurális } \\
\text { - metrikus } \\
\text { - skálás } \\
\text { - parciális }\end{array}$ \\
\hline $\begin{array}{l}\text { 3. Feltételezésem szerint } \\
\text { minden térségi szint ese- } \\
\text { tében igaz, hogy az adott } \\
\text { térségben tapasztalható } \\
\text { területi kötődés szint és } \\
\text { a térség társadalmi-tőke } \\
\text { szintje között egyértelmű } \\
\text { összefüggés, elméleti és } \\
\text { empirikus együtt járás } \\
\text { tapasztalható. }\end{array}$ & $\begin{array}{l}\text { A térségeket } \\
\text { átható kapcso- } \\
\text { lathálózatok } \\
\text { mennyisége } \\
\text { és minősége } \\
\text { hatással van a } \\
\text { térség kohézió- } \\
\text { jára. A területi } \\
\text { kötődés és a } \\
\text { társadalmi tőke a } \\
\text { hálózatképződés } \\
\text { egyik fontos } \\
\text { eleme. }\end{array}$ & $\begin{array}{l}\text { Együttmozgás } \\
\text { az empirikus } \\
\text { vizsgálatokban, az } \\
\text { operacionalizált } \\
\text { változók esetében. }\end{array}$ & $\begin{array}{l}\text { - Társadalmi } \\
\text { hálózat } \\
\text { - Helyi társadalom } \\
\text { - Területi kohézió } \\
\text { - Területi tőke }\end{array}$ & $\begin{array}{l}\text { Társadalmi tőke } \\
\text { - Általánosított } \\
\text { bizalom } \\
\text { - Intézményekbe } \\
\text { vetett bizalom } \\
\text { Területi kötődés } \\
\text { - Településhez } \\
\text { - Megyéhez } \\
\text { - Régióhoz } \\
\text { - Országhoz } \\
\text { - Európához }\end{array}$ \\
\hline
\end{tabular}

Forrás: saját szerkesztés 


\section{A TÁRSADALMI TŐKE ELMÉLET ALAPJAI}

A társadalmi tőke elmélet az egyik leginkább kedvelt és alkalmazott gyüjtőelmélet a kortárs társadalomtudományokban. Népszerüségét jelzi, hogy a kilencvenes évek közepéhez köthető elterjedése óta cikkek ezrei és könyvek százai használták fel elemzéseik háttereként, elemzési eszközként. A társadalmi tőke olyan ideává vált, amely maga jelképezi a társadalom szövetét, illetve annak állapotát. Az elmélet fontos elemeiként tartják számon az emberek közötti jó szándékot, reciprocitást és bizalmat, valamint az együttmüködési hajlandóságot. A megléte pozitív képet fest a társadalomról, és hatalmas előnyök tárházát nyitja meg előtte, míg a hiánya kóros tendenciákra hívja fel a figyelmet, és problémák kialakulását okozhatja a társadalmi élettel kapcsolatban.

Első használatát Hanifan (1916) nevéhez köthetjük, aki a vidéki iskola-közösségi központokról írt cikkében arra használta a fogalmat, hogy megnevezze „azokat a kézzel fogható anyagokat, amelyek a legtöbbet számítanak az egyén mindennapi életében" (Hanifan 1916, 130). Hanifant kifejezetten érdekelte a jóakarat, testvériesség, szimpátia és társadalmi érintkezés azok között az emberek között, akik kiadnak egy társadalmi egységet. Hanifan után a következő jegyzett felhasználó Jacobs (1961), aki jóval később, a hatvanas években használta a fogalmat a városi lét és a szomszédsági kapcsolatok elemzésére (Orbán-Szántó 2005; Field 2003).

A társadalmi tőke fogalmának elterjesztését elősegítő kutatók közül három prominens személyiség emelendő ki: Pierre Bourdieu (1977, 1979, 1980 és 2001), James S. Coleman $(1973 ; 1988,1990)$ és Robert D. Putnam $(1995,2000$; Putnam et al., 1993). 
Bourdieu egy korai definíciója a társadalmi tőkéről így szól:

„A nagyvilági - társadalmi kapcsolatok tökéje, amelyek - ha szükséges hasznos támogatást tudnak nyújtani; a tisztesség és tiszteletreméltóság tökéje, amely gyakran szükséges a társadalom bizalmának megszerzéséhez, biztositásához, és amiböl birtokosai hasznot húzhatnak politikai karrierjük során." (Bourdieu 1979, 133 o.)

Ezen definícióban Bourdieu lefekteti, hogy a társadalmi tőke által biztosított társadalmi kapcsolatok és társadalmi helyzet szükséges a politikai és társadalmi szerepvállaláshoz, a jó pozíciók eléréséhez. A társadalmi tőkét a hálózatokban létező, kollektív erőforrásnak tekintette, amely azonban a hálózaton keresztül delegálhatóvá válik az egyén számára, aki képes lesz profitálni abból (Bourdieu 1980).

Későbbi mủvében azonban Bourdieu (2001) már amellett érvel, hogy a társadalmi kapcsolatok alaperőforrások, amelyek elhelyezik az egyént a hierarchiában és a komplex társadalmi struktúrában. A társadalmi hálózatok elismerik tagjaik hozzáférését az értékes kollektív erőforrásokhoz, és szerepet játszhatnak az egyének társadalmi és gazdasági státuszában. Rámutat arra, hogy a gazdasági és anyagi feltételek a társadalmi folyamatok fejlesztésének az alapvető összetevői, és azért számításba kell venni őket a társadalmi tőke bármilyen mérésében.

Coleman (1988) szintén az emberi kapcsolatok eredményeként látja a társadalmi tőke létrejöttét a társadalmi szerkezet kontextusában. Mindazonáltal szerinte az egyének nem hoznak létre olyan társadalmi tőkét, amit gazdasági vagy anyagi körülmények korlátoznak. Mivel elhiszik, hogy azáltal, hogy társadalmi csoportokat és hálózatokat hoznak létre, elősegítik a kollektív cselekvést, ezért maximálni fogják az egyéni potenciáljukat és lehetőségeiket. Coleman (1988) a normák és értékek, kölcsönös bizalom, kölcsönös kötelezettségek és elvárások, társadalmi hálózatok és társadalmi szervezetek szerepét hangsúlyozza a társadalmi tőke teremtésében. Egy definíciója:

„Ha a racionális döntések elméletét vesszük, amiben minden egyes cselekvö bizonyos eröforrásokat és érdekeket irányít bizonyos eröforrásokban vagy eseményekben, a társadalmi töke egyfajta eröforrás lesz, ami a cselekvö rendelkezésére áll." (Coleman 1988, 98 o.) 
A társadalmi tőke szerinte a kapcsolatokban létezik, a személyközi viszonyok alakulásával jön létre, és elősegíti a produktív cselekvést. Coleman azt írja, hogy a társadalmi tőke akkor fejti ki pozitív hatásait a társadalmi és politikai részvételre (pl. választási részvétel esélyének növelése), ha két feltétel teljesül: (1) kellően kompaktak a releváns társadalmi hálózatok a megfelelő ösztönzés eléréséhez, illetve (2) a választás tétje elég jelentős-e ahhoz, hogy ennek mentén elkülönüljenek a különböző hálózatok preferenciái (Coleman 1990, idézi: Angelusz-Tardos 2003). Ez a példa jól illusztrálja a társadalmi tőke kollektív erőforrás jellegét, amit Coleman propagál.

Programadó tanulmányában James S. Coleman különleges érdeklődést mutatott (1988) az iránt a jelenség iránt, amikor a társadalmi tőke az emberi tőke megszerzésében és fejlesztésében, mint alapvető erőforrás jelenik meg (különösképp a gyerekek családon és közösségen belüli oktatása és fejlesztése kontextusában). Amellett érvel, hogy a család szerkezetén belül kifejlődött kapcsolatok alkotják a család társadalmi tőkéjét. Ebben a kontextusban a társadalmi tőke több szerkezeti tényezőtől függően fog változni. Ragaszkodva ehhez a nézethez, a szülők háztartásban való fizikai jelenlététől vagy hiányától függően változik a figyelem menynyisége és minősége, amit a gyerek/gyerekek a családi körön belül a szülőktől és/ vagy más felnőttektől kapnak, illetve családi szinten a gyerek/gyerekek és a szülők kapcsolata fogja meghatározni a társadalmi tőke milyenségét. Portela Maseda és Neira Gómez (2003) támogatja Coleman elméletét a családon belüli társadalmi tőkével kapcsolatban, és felvetik, hogy az emberi tőke egy nemzedékről csak akkor fog átöröklődni a következőre, ha a családon belüli társadalmi tőke szintje magas.

Putnam társadalmi tőke elmélete (Putnam et al. 1993, Putnam 1995, 2000) fontos kapcsolatban áll azzal a társadalmi kontextussal, amelyben megszületett. Két müvében (Putnam et al. 1993; Putnam 2000) két különböző demokratikus rendszerben is bemutatja a társadalmi töke keletkezését és müködését: Olaszországban és az Egyesült Államokban. Mindkét esetben szoros összefüggést talál a jól múködő társadalmi-politikai struktúra és a társadalmi tőke magasabb szintje között. Az ő elgondolásában a társadalmi tőke és a közjó fogalma rokonítható, a társadalmi tőke kifejeződhet például a polgári erények társadalomban történő erős megjelenése által. A tudós a közösségi részvételt tekinti a társadalmi integráció legfontosabb elemének, és könyvében (2000) a tőketípus szintjének veszélyes mértékü visszaesésére figyelmeztet. Ez a visszaesés az ő olvasatában egyaránt veszélyezteti az amerikai demokráciát és az amerikai társadalom integráltságát. Állításait több 
dimenzió mentén igyekszik bizonyítani és növelni közönsége elkötelezettségét a részvétel valamely formája mellett.

A Putnam által megfogalmazott társadalmi tőke elmélet egyik legtöbb vitát kiváltott dimenziója a demokratikus részvétellel kapcsolatos dimenzió. A társadalmi tőke szintjét erősítő részvétel formája lehet civil részvétel, azaz a közösségi életbe bekapcsolódás, illetve lehet a politikai életbe történő bekapcsolódást jelentő politikai részvétel is. Robert Putnam 1995-ben megjelent cikke és 2000-ben megjelent hasonló címủ könyve, a „Bowling Alone” összekötötte a részvétel ezen két jelentős dimenzióját. A szerző összefüggést feltételezett a közösségi részvétel hanyatlása és a politikai részvétel visszaesése között. Elmélete sok kritikát kapott (vö. Portes 1998, 2000) azon az alapon, hogy nem tudhatjuk, vajon a részvételi szintek visszaesése nem egy normális folyamat eredménye-e, illetve, hogy a magas szintű részvétel nem feltétlenül eredményez egészséges társadalmat.

Putnam gondolatmentéből egyértelmủen következik a társadalmi tőke azon vonása, hogy a tőketípus szintje elméletileg korlátlan mértékben növelhetö, és abból nem zárható ki senki, aki részt vesz a társadalmi életben. Más tőketípusok, így az anyagi tőke és az emberi tőke esetében például egyértelmü korlátokkal állunk szemben. A gazdaságban nincsen korlátlan értékü, mindenki számára egyenlően elérhető anyagi erőforrás, az emberi tőke fejlesztése pedig igen költséges és időigényes ráfordítással (tanulás, tapasztalatszerzés) lehetséges csupán. Ezekkel a nehezen növelhető és korlátozott mértékben hozzáférhető tőketípusokkal szemben a társadalmi töke szintjét automatikusan növeli a használat, azaz a társadalmi életben való részvétel, valamint az interakciókon keresztül megszerzett és megadott bizalom. A használat által növelhető mértékủ társadalmi tőke elméletben minden ember számára elérhető lehet, hiszen mindenki számára lehetséges, hogy bebizonyítsa, méltó a bizalomra - természetesen az elfoglalt társadalmi pozícióiknak megfelelő mértékben (Cox 1995, 1998; Putnam 2000).

Jelen munkám témája szempontjából kiemelt fontosságú Robert D. Putnam és kollégái 1993-as müve, mely a „Making Democracy Work”címmel jelent meg, és lényegében egy társadalmi töke vizsgálat eredményeit mutatta be az olasz régiókban. A mü összekötötte a régiók társadalmi töke szintjét a regionális kormányzatok teljesítményével, és felismerte a regionális identitás szerepét is az előbbiek szempontjából. 


\subsection{A TÁRSADALMI TŐKE LEGFONTOSABB DIMENZIÓI}

A társadalmi tőke nem csupán az egyén szintjén értelmezhetô, illetve értelmezendö, hanem a közösségek, csoportok, network-ök, azaz a társadalmi hálózatok különböző szintjein is. A társadalmi tőke magas szintje kooperációhoz vezet, és normák kialakulását eredményezi. Az így kialakult normákat különféle módokon nevezzük. Ezen normákra példa az úgy nevezett polgári erényeknek az egyének szintjén, illetve a közbizalomnak a társadalmi csoport szintjén történő kialakulása Európában és az Egyesült Államokban is. Egy erkölcsös, erényeken alapuló, bizalomra épülö társadalom esetében alapkövetelmény, hogy a tagjai is betartsák azokat az alapnormákat, amelyeket a csoportjuk, illetve network-jük meghatározott, különben kizáródnak abból (Cox 1995; Putnam 2000).

A tőketípus egyik legfontosabb eleme a bizalom dimenziója. A kölcsönös bizalom, azaz az emberek egymásba vetett bizalma minden fél számára előnyös lehet. A közbizalom egy normális társadalmi rend alapja kell, hogy legyen, nélküle nehezen képzelhető el a társadalmi élet. A gazdasági szervezetek és szereplők közötti bizalom pedig a globális világgazdaság múködésének előfeltétele, a megléte pedig gazdasági növekedést eredményez. A társadalmi tőke szintjének esetleges csökkenése természetesen azonnal megmutatkozik mindhárom korábban említett bizalmi dimenzióban. Ha kiemeljük a gazdasági dimenziót, és arról szeretnénk egy fontos állítást tenni, Fukuyama írása (2007) alapján elmondhatjuk, hogy a társadalmi tőke szintjének csökkenése ebben a dimenzióban a legtöbb esetben konkrét és megfogható anyagi veszteségekhez vezet. Fukuyama azon túl, hogy James Coleman alapján bevezei a társadalmi tőke fogalmát, példákat is mutat arra, hogy miként áshatja alá a bizalom hiánya a közösségek érdekérvényesítő (legyen szó akár az önérdek érvényesítésérool, például egy közösség infrastrukturális vagy kulturális fejlődéséhez nélkülözhetetlen döntéseinek halogatása) képességét. Mint fukuyama megjegyzi, a társadalmi tőke azzal a képességgel azonos, hogy „csoportokban és szervezetekben együtt tudjunk dolgozni embertársainkkal közös célok elérése érdekében" (Fukulyama 2007, 23). Fukulyama ugyanakkor felhívja a figyelmet arra is, hogy a társadalmi tőke a kapcsolatok különböző erősségü viszonyrendszerében aknázható ki a legteljesebb módon: nem a csoport belső kohéziója, az erős kötések dominanciája a döntő, hanem a gyenge kötésekre való fogékonyság, az „outsiderek" bevonására való hajlandóság léte vagy hiánya a bizalom igazi próbaköve. A csoporton belüli bizalom gyakran gátló tényezőként müködhet, az újítások, 
fejlesztések, a továbblépés lehetősége ugyanis a leggyakrabban kívülről érkezik. Fukuyama $(2000,11)$.

A másik kulcsdimenzió az azonnali viszonzás reménye nélküli reciprocitás dimenziója. Ha reciprocitásról beszélünk, elsősorban a szimmetrikus reciprocitásra gondolhatunk. Magas szintű társadalmi tőke esetén a reciprocitás aktusa során a viszonzást nyújtó személy változhat, illetve a viszonzás ideje egy későbbi időpont lehet. Itt fontos megemlíteni a szolidaritás fogalmát, amelyet a későbbiekben tárgyalunk.

A társadalmi tőke müködésének alapvető feltétele a kapcsolat-hálózatok kompaktsága, azaz a tagok összekapcsoltsága és egymás iránti szimpátián túlmutató elkötelezettsége. A laza, de kompakt hálózatok ígérik a legtöbb és leghasznosabb társadalmi tőkét tagjaik számára. Azonban a túl erős elkötelezettséggel járó, erősen összekapcsolt, erős kapcsolatokból álló hálózatok felemészthetik tagjaik energiáit. Ezen erős kapcsolatok ápolása sok időbe és sok ráfordításba kerül, és ezáltal hátrányba kerülhetnek az ilyen jellegü hálózatok tagjai a társadalmi életben. A társadalmi hálózat, melyben a társadalmi tőke termelödik, meg is határozza annak típusát.

\subsection{A TÁRSADALMI TŐKE SZEREPE A DEMOKRATIKUS TÁRSADALMAKBAN}

A társadalmi tőke olyan erőforrás, amely vitathatatlanul jelen van a társadalom több alrendszerében is. A demokratikus társadalmakban a civil társadalom kontextusában is értelmezhetjük; horizontálisan szervezett, kölcsönös kapcsolatokra alapozódva létezik a társadalmi hálózatokon belül. Ezen kapcsolatok azok között alakulnak ki, akik a demokratikus társadalmak müködését segítő politikai intézmények létrehozásában az élen járnak. A demokrácia azokban a közösségekben fontos érték, ahol a bizalom, polgári elköteleződés, kölcsönösség, szolidaritás és integritás értékadó fogalmaknak számítanak. Putnam és szerzőtársai (1993) - az olasz kormányzatról írt munkájukban - úgy találták, hogy a decentralizáció során megalakult regionális kormányok új kezdeményezésekre való fogékonyságában a társadalmi tőke szerepe meghatározó volt. A politikai és adminisztratív decentralizáció (és a hatalom különböző szintjeinek más régiókba való áthelyezése a központi kormány által) kiterjeszti az egyenlőtlenségeket és különbségeket a régiók 
között, és csökkentheti a közérdek érvényesítésének hatékonyságát, illetve megváltoztathatja a magánérdek érvényesítést szabályozó normákat.

Későbbi munkáiban Putnam (1995, 2000; Putnam-Feldstein 2004) a társadalmi tőkét az önkéntes szervezeti tagságból vezette le. Egyértelmúen párhuzamot vont a társadalmi tőke mértéke és a politikai részvétel intenzitása között. Véleménye szerint az USA-ban a politikai és társadalmi részvétel '50-es évektől kezdődő viszszaesésének fő oka a társadalmi tőke nagymértékü lerombolódása. Feltételezése szerint tehát az a társadalom egészséges és jól müködő demokráciával rendelkező társadalom, ahol a társadalmi tőke szintje és ezáltal a politikai részvétel intenzitása egyformán magas. Putnam ezen elmélete nagyban támaszkodik a „közjó” elgondolására, és a legtöbb kritikát azért kapta, mert a társadalmakat csak az imént említett kritériumok teljesülése esetén tartja egészségesnek. Kritikusai felvetik, hogy legfőbb hibájaként nem akarja egy alternatív társadalomfejlődési mód lehetőségét tekintetbe venni elméleteinek kidolgozásakor (Portes 1998, 2000).

Rico, Fraile és González (1998) más nézőpontból közelít a társadalmi tőke és demokrácia kérdéséhez. Bemutatják, hogy a spanyol regionális rendszerben a területi gazdasági fejlesztés és társadalmi töke közötti kapcsolat nem szignifikáns. Kutatásaik azonban megerösítik, hogy a társadalmi tőke az önkormányzati sikeresség és hatékonyság egyik alapvető meghatározója, melyet csak erősít a nyilvános forráselosztás intézménye. A decentralizáció összefüggéseiben úgy érvelnek, hogy az autonómia fokának (politikai decentralizáció) és az önkormányzati munka minőségének pozitív hatása van a törvényhozói teljesítményre. A regionális Spanyolországban a politikai decentralizáció törvényhozói hatékonysággal és elszámoltatható kormányzati teljesítménnyel párosul. Megemlítendő, hogy a „változó geometria elve" Spanyolországban is érvényesül, és vannak mesterséges régiók különböző státuszokkal, ahol a fenti állítások épp ebből adódóan nem feltétlenül bizonyulnak igaznak.

\subsection{RÉSZVÉTEL ÉS TÁRSADALMI TŐKE}

Putnam a társadalmi tőke fogalmát arra használja, hogy az önkéntes társulatokban való részvételről (állampolgári elkötelezettségről), intézményes tevékenységekről és demokratikus kiadásokról szóló tanulmányában feltárja a társadalomban betöltött funkcióit. Putnam és szerzőtársai (1993) azt mondják, hogy a közügyekben való aktív részvétel a jól működő civil társadalmak megkülönböztető jellemzője. 
Amellett érvelnek, hogy a társadalmi tőke olyan forrás, ami szoros kapcsolatban van az egyének közös munkára, illetve közös célok elérésére irányuló kollektív kapacitásával. Az embereknek közös érdeklődést kell mutatniuk, és törekedniük kell a kölcsönös haszonra, hogy lehetővé tegyék a társadalmi tőke felhalmozását. Ezeket a célokat az önkéntes társulások és az állampolgári elkötelezettség más formáinak megteremtésével és fenntartásával lehet elérni. Putnam (1995) arra is rámutat, hogy az állampolgári elkötelezettség, a kölcsönösség és a társadalmi tőke összekapcsolódnak. A társulásokban való elkötelezettség által az emberek bátorítják egymást, hogy kiszámíthatóan, hasonló mozgatórugók alapján hasonlóan cselekedjenek. Ez a generalizált kölcsönösség normáin alapszik, és szintén segíti a kölcsönös bizalmat a kommunikáció és kollaboráció folyamának szabadon engedésével.

Az önkéntes társasági tagság a társadalmi tőke értékes indikátora (StolleRochon 1998; Weiss 1996). Coleman (1988) szintén úgy látja, hogy a társadalmi tőke az egyén és a csoport kapcsolatán alapuló forrás, ami megkönnyíti az adott célok eléréséhez és hasznok termeléséhez szükséges tetteket.

Véleményem szerint fontos hangsúlyozni a magas szintủ részvétel jelentős szerepét a társadalmi tőke fejlódésében, illetve még konkrétabban a kollektív célok sikeres elérésében. Úgy tekintem, hogy azokban a közösségekben, ahol a tagok együtt dolgoznak (a kölcsönösség normáit használva: a fontos problémák megoldásához szükséges információk megosztásával és általában a kooperatív stratégiák sikeres fejlesztésével), produktív folyamatok fognak beindulni, melyeknek katalizátorai a kooperáció minőségét is meghatározó említett tényezők. Az ilyen alapokra helyeződött együttmüködő közösségek probléma megoldási képessége kiemelkedő lesz, a problémák kezelése pedig példaértékü. Az ilyen jellegü kooperációk a leghasznosabbak a társadalom számára, ám a létrejöttüket akadályozhatja néhány objektív, az adott társadalomra jellemző adottság: ilyen lehet például az általános bizalom alacsony szintje, a közös normák hiánya és az állampolgári kötelezettségek internalizálatlansága.

A társadalmi tőke magát „,szoros kölcsönös kapcsolatként értelmezi az állampolgári elkötelezettség és az emberek közti bizalom között. Minél inkább résztvevői az állampolgárok a közösségüknek, annál inkább megtanulnak bízni másokban, a nagyobb állampolgári bizalom miatt pedig egyre inkább résztvevők lesznek." (Brem-Rahn 1997, 1001-1002.) Emellett Cox $(1995,1998)$ azt állítja, hogy azok az emberek, akik önként fektetnek időt és energiát valamilyen kollektív részvételbe, segítik építeni és növelni a társadalmi tőkét. Ez összetett folyamat: 
kölcsönösen hasznos kapcsolatot építünk ki másokkal a mi és az ő társadalmi tettekben való szabad részvételével. Ezek a kapcsolatok érdeklődésbeli különbségek közösségi vitáján és bizalmon alapulnak - utóbbi segíti a tolerancia és a szolidaritás fejlesztését, ami nagyon fontos a konfliktuskezelés folyamatában. Ez a jelenség leginkább egalitárius közösségekben jelenik meg. A közös célok azonosítása és azok elérése lehetőségeinek felmérése alapvető fontosságú ahhoz, hogy megteremtsük a kooperációt és a kölcsönösség érzését. Mindkét tett utal a személyes szint és a közösségi szint hatásfokára (pl. Az emberek kontrollszintje személyes és közösségi ügyekben) és a bizalom elegendő szintjére, ami megkönnyíti a közös célok elérését. Gregory (1999) amellett érvel, hogy a „kooperatív bizalom”-nak meghatározó szerepe van a közjó elérésére irányuló közintézményi ügyekben.

Almond és Verba (1963), akik a „témaorientációt” hangsúlyozzák (illetve a törvényt követve a részvételben megjelenő törekvést a közös célok elérésére), azt is mondják, hogy az embereken múlik, hogy a tisztán egyéni döntéseiken túl elérnek-e kollektív hasznokat. Brehm és Rahn (1997) amellett érvelnek, hogy azokban a társadalmakban, ahol az egyének összegyülnek, hogy közös célokat érjenek el, megoldhatnak kollektív problémákat. Foley és Edwards (1998) egyetértenek azzal, hogy az önkéntes társaságokban való részvételnek hatása van az interperszonális bizalomra, a kooperációra és a szociális hálózatok megteremtésére. Bár amellett is kiállnak, hogy a különböző típusú társaságok és a különböző kontextusok különböző eredményekhez vezethetnek.

Grootaert (1998.) azt írja, hogy az állampolgári elkötelezettség (ami a társadalmi tőke egy indikátora) mérése összetettebb annál, hogy megszámoljuk az önkéntes társulásokat és tagjaikat. A definíció szerint a társadalmi tőke az állampolgári társulásokra, mint közös célok elérése érdekében ható kollektív eszközökre referál. Ha ez így van, akkor az állampolgári elkötelezettség mérése magában foglalja a közös célok meghatározását, és kiterjeszti az eddig elért célok feltárását. Stone (2001) rámutat arra, hogy nem csak a formálisan felépülő társadalmi csoportok elkötelezettségének intenzitása, hanem az ezeken belül fejlödött kapcsolatok minőségének vizsgálata is kell a társadalmi tőke méréséhez.

Elgondolásom szerint az állampolgári elkötelezettség megléte és az állampolgári erények internalizálása elengedhetetlen az egészséges társadalmi élet feltételeinek megteremtéséhez. Felismerte ezt az Európai Unió is, amely a többi társadalmi és politikai intézménynél modernebb eszközökkel igyekszik növelni elfogadottságát polgárai körében. 


\subsection{A TÁRSADALMI ÉS A POLITIKAI TŐKE KÜLÖNBSÉGEI}

Ahogy már említettük, a társadalmi tőke Putnam elgondolása szerint elemi hatással van a civil és politikai részvételre. Szerinte a két részvételi típus hatással van egymásra is: a civil aktivitás és az önkéntes szervezeti tagság és szerepvállalás befolyásolja a politikai részvételt. Putnam küzdelme az amerikai demokrácia védelmében azon az elgondoláson alapul, hogy ha az amerikai társadalom atomizálódása bármilyen közösségi tevékenység revitalizálásával vagy újra elterjesztésével megállítható, az nagyban javítani fogja a politikai részvétel fokát is. A nagyobb mértékü politikai részvétel (főleg a választási részvétellel mérve, de más változókkal is illusztrálva) pedig meggátolhatja az amerikai demokrácia erodálódását (Putnam 2000).

Fuchs, Minnite és Shapiro az Egyesült Államokban lezajlott kutatásukban más eredményre jutva bemutatták, hogy a társadalmi tőke elméletnek a politikai részvétel visszaesésének magyarázatában komoly korlátai vannak, különösen a szegény városi közösségek esetében. Ha a társadalmi tőkét kollektív értéknek tartjuk - egy eszköznek a közösségépítésben, amely végül el fog vezetni a problémák megoldásához, amelyekkel a szegény városi közösségek szembenéznek -, nagyon fontos, hogy megértsük, hogyan köti össze az egyéneket és közösségeket a politikai folyamatokkal. A politika az a színtér, ahol a városi érdekcsoportok, ha tetszik, rétegek koalíciókat alakíthatnak ki, illetve szövetségre léphetnek egymással.

Mivel a politika színterét a társadalmi tőke elmélet nem, vagy csak korlátozott mértékben vizsgálja, Fuchsnak és szerzőtársainak az a nézetük, hogy a hagyományos társadalmi tőke elmélet nem képes teljesen kielégítő magyarázatot adni a politikai részvétel visszaesésére, különösen a városi demokráciákra vonatkozóan. Azért nem képes, mert a városi politikai részvételi hagyományt vizsgáló kutatások helytelen konceptualizáción alapulnak; itt az összefogás jobban gyökerezik a konfliktusban, mint a konszenzus kialakításában (Fuchs-Minnite et al. 1998).

Annak érdekében, hogy jobban megvilágítsák a városi demokrácia és a társadalmi tőke közötti kapcsolatot, Fuchs és szerzőtársai kidolgoztak egy koncepciót, amit ,politikai tőkének” neveztek el. A politikai tőke konceptualizálása során figyelembe vettek több olyan változót, amelyet a társadalmi tőke megközelítése során egyáltalán nem szokás, ezáltal „kifinomultabb” keretet hoztak létre a politikai részvétel mértékének vizsgálata és potenciális növelése számára. 


\section{1. ábra - A társadalmi és politikai tőke viszonya}

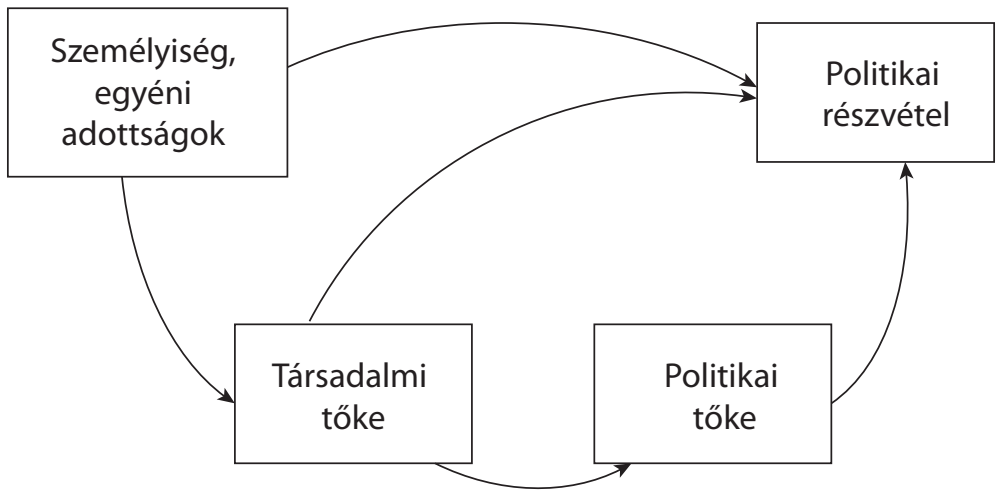

Forrás: Fuchs-Minnite-Shapiro1998, 9

Az 1. ábrán látható a társadalmi tőke és politikai képződésének leegyszerüsített folyamata, mely a legtöbb teoretikus által elfogadott mechanizmusokat modellezi, hiszen a társadalmi tőkét, mint fő magyarázó változót használó tudósok sem tagadják a politikai tőke fogalmának létjogosultságát.

A politikai tőke éppúgy, mint a társadalmi tőke, az emberek közötti kapcsolatokon alapul. Szintén önkéntes szervezeti tagságon keresztül szerezhető meg, beleértve a szociális és egyházi szervezeteket is, de csak akkor, ha ezek a szervezetek szintén belefolynak a politikai tevékenységbe.

Valószínüsíthető, hogy a politikai tőke a társadalmi tőkétől függetlenül is megszerezhető, például sok szervezet használja meglévő társadalmi tőkéjét politikai tőke felhalmozása céljából. Jó példa erre a politikai színtéren Európában változó mértékben sikeres, Római Katolikus Egyház által támogatott kereszténydemokrata pártok esete. Míg Nyugat-Európában a választási sikertelenség és általános érdektelenség miatt már szinte teljes mértékben eltűntek a kereszténydemokrata formációk, addig például Magyarországon továbbra is sikeres módon politizál a KDNP. A pártokat támogató egyház célja feltehetően a társadalmi értékrend befolyásolása, azaz saját értékrendjének nem csak a civil és vallási, hanem politikai szférában is való kommunikációja (Casanova 1995). Érdekes adalékként szolgálja az előbbi példa megértését, hogy az ilyen módon politikai tőkéhez jutó közösségi szervezeteknek a politikai partnerekkel való együttmüködése általában konfrontációs vagy konfliktusos stratégiából alakul ki (Fuchs-Minnite et al. 1998). 


\subsection{A TÁRSADALMI TÖKE KÜLÖNBSÉGEI A TÖBBI TŐKETÍPUSHOZ KÉPEST}

Nan Lin (2001) úgy definiálja a tőkét, mint befektetett erőforrások összességét, amelyekért más erőforrásokat vehetünk igénybe a piacon. Úgy egészíti ki a definíciót, hogy szerinte a tőkét általában befektetjük, és akkor mozgatjuk, ha felmerül a profitálás lehetősége. A következő néhány bekezdésben csupán felsorolásszerüen bemutatunk még néhány, a társadalmi tőke mellett a társadalomtudományok által használt tőketípust.

Hagyományos, más néven gazdasági tőkének a Marx által kidolgozott tőkekoncepciót tekinthetjük (Marx 1867, idézi: Lin 2001). Ebben a javak elóállítását a munkások végzik, akik munkájukért a kapitalistáktól fizetést kapnak, amely maga a gazdasági tőke, és azt maguk is javak vásárlására fordítják. Marx elmélete a társadalmi osztályok egyenlőtlenségére, a munkásosztály kizsákmányolására épít a tőkés vagy más néven burzsoá osztály által.

Az emberi tőke egy másik tőketípus, amelyről a társadalmi tőke elmélet egyik atyja, J. S. Coleman is írt „Társadalmi tőke az emberi tőke termelésben” címü, 1988-ban megjelent cikkében. Az emberi tőke lényegében az a képzettség, amit a munkaerejét eladni kívánó személy megszerzett, annak érdekében, hogy munkájáért több pénzt kaphasson, azaz jobb arányban válthassa gazdasági tőkére. Emellett azonban az emberi tőke magasabb fokának megszerzése együtt jár a magasabb társadalmi tőke megszerzésével is, illetve az emberi tőke mértéke szelekciós kritérium lehet bizonyos kapcsolathálózatokba való bejutás esetén is. Az emberi tőkét a munkás saját akaratából szerzi meg.

A kulturális tőke fő teoretikusa, Bourdieu (2001 illetve Bourdieu és Passeron 1977) szerint az nem azonosítható az emberi tőkével. A kultúrát szimbólumok és jelentések rendszereként definiálja. Elgondolása szerint a társadalom felsőbb osztályai saját kulturális rendszerüket az oktatás rendszerén keresztül teszik elérhetővé a kiválasztott kevesek számára. Lényeges különbség az emberi tőkéhez képest, hogy a megszerzését nem a személyek saját akaratának tulajdonítja, hanem az uralkodó osztály szimbolikus hatalmának, melyet az rákényszerít a társadalom egészére.

A politikai tőkéről már szót ejtettünk az előző fejezetekben (Fuchs, Minnite, Shapiro 1998), lényegében az is hasonló keretek között keletkezik, mint a társadalmi tőke, ám például olyan önkéntes szervezeti részvételen keresztül, melyek nem kizárólag társadalmi, hanem politikai szerepvállalást is folytatnak. 
A területi tőke egészen új elméleti konstrukcióját adja cikkében Camagni (2009). A szerző azt mondja, hogy a területi tőke, mint autonóm tőketípus megállja a helyét, és jobban használható a regionális fejlesztés és növekedés elemzéséhez, mint külön a társadalmi tőke vagy bármely más tőketípus. A területi tőkét Camagni cikkében a könnyen és nehezen hozzáférhető közjavak, a magánjavak, a társadalmi tőke és az attól megkülönböztetett kapcsolati tőke, az emberi tőke, a társadalmi hálózatok és magán hálózatok alapján konceptualizálja. A területi tőke, mint új területi alapon szerveződő erőforrás új eredményeket ígér az azt alkalmazó térségi kutatásokban.

Áttekintve néhány másik tőketípust, Nan Lin (2001) valamint Portela Maseda és Neira Gómez (2003) müvei alapján elmondható, hogy bár a társadalmi tőkében megvan néhány másik tőkefajta több jellemzője is, azokhoz képest mégis több fontos különbséget mutat. Egyrészt a társadalmi tőke olyan „vagyon”, ami hasznot termel, és kiegészíthet több másfajta tőkét is. Képes más tőketípusok helyettesítésére; másfajta tőkévé konvertálható, illetve, ahogy másfajta tőkék esetében, a befektető a befektetésétől azt várja, hogy a mennyisége gyarapodjon. Másfelöl társadalmi tőkét nehéz a társadalmi élet bevett keretein kívül létrehozni², illetve nehéz meghatározni és mérni azt. Mégis azt a nézetet támogatják, hogy a társadalmi tőkére tekintsünk úgy, mint egy önálló tőketípusra, és ennek, bár minden tőke valahol összefügg egymással, a legerősebb a kapcsolata az emberi tőkével.

Grootaert és Van Bastelaer (2002) szintén önálló tőkének tartják a társadalmi tőkét, és mint ilyen, szerintük felhalmozható vagy erőforrásként értelmezhető, ami hasznot termel. Amennyiben erőforrásnak tekintjük, a különböző együttes hasznok a közös fellépésen és az információcserén alapszanak. Ez olyan fajta „vagyon”, ami nem oszlik meg a társadalomban, de olyan is, ami nő, ha használják - és ami a használat visszaesésével fogyni kezd. A haszon (vagy a lehetőség a haszonra) a részvételen és a társadalmi bizalom szintjén múlik. Bizonyos szempontból társadalmi tőkére gondolhatnánk a közösségek, társadalmak és nemzetek társadalmi egészségességének indikátoraként (Putnam 2000; Kopp 2008).

Stone és Hughes (2002) úgy emlegetik a társadalmi tőkét, mint valami „ragasztót, ami összetartja a közösségeket”. Coleman (1988) szintén úgy tekint a

\footnotetext{
2 Az, aki ki van rekesztődve a társadalmi élet bizonyos színtereiröl, aligha fog tudni ott hasznos társadalmi tőkét gyüjteni. Ilyen kirekesztett helyzetben lévő csoportok például a hajléktalanok, illetve egyes marginalizálódott etnikai csoportok, így a romák. Ez persze nem zárja ki, hogy az említett csoportok tagjai saját közösségükben társadalmi tőkével rendelkezzenek, ám ez a típusú társadalmi tőke kizárólag az adott közösségben, és nem a társadalmi életben lesz hasznos.
} 
társadalmi tőkére, mint több entitásra vagy dimenzióra, amelyeknek két közös elemük van: a társadalmi szerkezet és az azon belüli cselekvések. Coleman megközelítésével: a társadalmi tőke megengedi az egyénnek, hogy azonosítsa a társadalmi szerkezetnek azon speciális jellemzőit, amelyek erőforrásokként lehetnek hasznosak, hogy együttes törekvéseket valósítsanak meg. Eastis (1998) úgy fogalmaz, hogy a társadalmi tőke többdimenziós, és amellett érvel, hogy társadalmi tőkére alapvető hatással vannak azoknak a hálózatoknak, szervezeteknek és tényezőknek a jellemzői, amelyek szerepet játszottak a teremtésében. A társadalmi tőke fogalmának komplexitása és különböző dimenziói arra mutatnak, hogy egyénileg kell feltárni az elemeit. Portela Maseda és Neira Gómez (2003) szerint a társadalmi tőkét különböző fajta „vagyonok” (társadalmi, pszichológiai, kulturális, kognitív stb.) alkotják, és azok a vagyonok segítenek majd megvalósítani a kölcsönös haszon irányába tett közös fellépést.

Stone (2000) megközelítésében a társadalmi tőke szerepe egyértelmúen tisztázott a társadalmi kohéziót elősegítő fejlesztések megvalósításában. Segítségével lehetővé válik a korrupció visszaszorítása és a közérdek elötérbe helyezése és figyelembe vétele az ügyekben. Növelésével növelhető az általános bizalom és biztonság szintje a társadalomban. A kutatóknak fel kell tenniük azt a kérdést, hogyan lehet társadalmi tőkét létrehozni, és azt hogyan terjeszthetik el, illetve hogyan müködik ez különböző szinteken és különböző körülmények között. Ezt szem előtt tartva Edwards és Foley (1998) rámutattak arra, hogy a legtöbb társadalmi tőkével kapcsolatos kutatás figyelmen kívül hagyja a társadalmi tőke jellemzőinek változataiban a politikai, gazdasági, társadalmi és kulturális összefüggések szerepét, úgyis, mint a részvétel, tolerancia és bizalom szempontjait.

Weiss (1996) hangsúlyozza a társadalmi tőke egyedi arculatát, és a tőketípus szerepét az erőforrások átváltására szolgáló „társadalmi tőzsdében”. Az átváltást és felhasználást támogatják a kölcsönös elvárások és kötelezettségek, a kölcsönösen értéket teremtő kapcsolatok müködése alapján. Az emberek különböző szinteken bonyolódnak bele a társadalmi kölcsönhatásokba (a részvétel, közös értékek és bizalom szintjei személyről személyre, csoportról csoportra változnak), hogy a speciális szükségeket kielégítsék. Ez a szükséglet szintjétől és az emberek elkötelezettségi szintjétől függően különböző mértékủ hasznokat hozhat.

A társadalmi tőke tehát egy igen fontos tőketípus, mely rendelkezik közös elemekkel a többi tőketípusból, ám önálló arculattal is. A társadalmi tőke segítségével elérhetőek olyan dolgok, amelyek a többi tőketípus önálló felhasználásával nem. Illetve adott a lehetőség a konverzióra, azaz az egyes tőketípusok más tőketípusra 
történő átváltására. A különböző tőke típusok közötti együttmüködés is hatékony lehet bizonyos társadalmi problémák kezelésében.

\subsection{A TÁRSADALMI TŐKE MEGJELENÉSE ÉS FORMÁI}

Amint már a korábbi fejezetrészben is írtam, a társadalmi tőke magába foglalja a kapcsolatok, normák és értékek hálózatait a társadalmi szereplők (egyének és szervezetek) között, ami hozzájárul a kölcsönös haszon eléréséhez. A különböző típusú társadalmi hálózatokból származó társadalmi tőkéket általában sikerül beazonosítani a különböző típusú hálózatok jellemzői, normái és tagjaira rótt kötelezettségei alapján. Az azonosítás alapjául szolgálhatnak továbbá azok a kapcsolatok, amelyek ezek közt a hálózatok közt fejlődnek, és a bizalom alapján, ami ezekből a hálózatokból és kapcsolatokból ered. A kötelezettségek és elvárások hatásos és társadalmilag támogatott normái, például azok, amelyek egy közös cél irányába való törekvésre bátorítanak, önmagukban is erőteljes szerkezetü társadalmi tőkét képviselnek (Coleman 1988). A különböző szociális szerkezetek különböző szociális tetteket követelnek, ezért lehetnek különböző formái a társadalmi tőkének (Coleman 1988). Bizalmat, normákat, elvárásokat és kötelezettségeket határoznak meg a társadalmi szerkezeteken belül az egyén vagy a csoportszükségletek faktora és a rendelkezésre álló erőforrások alapján, amelyek a szükségletek kielégítéséröl gondoskodnak. Ezen érvek sorában a „konszenzus” kifejezés hangsúlyozza az ilyesfajta megállapodások fontosságát az elvárások között, amelyeket különböző emberek felé támasztanak.

A családi élet, a fizetett munka és a közösségi élet minden formája az ember életének a része. Azért, hogy sikeres egyensúlyi helyzetet teremtsünk az élet különböző részei között, fontos, hogy az időt és más erőforrásokat arányosan rendeljük mindegyik területhez. Ha az emberek döntéseik során egy területet elönyben részesítenek egy másikkal szemben, az az említett egyensúly elvesztéséhez vezethet. Az egyensúly felborulása gyenge közösségi tetteket és bevonódást implikál, vagy néhány esetben teljes elzárkózást a közösségi élettől. A társadalmi kapcsolatok és az emberek közti viszonyok, tapasztalatok is részesei a közéleti és a magánéleti területek fejlődésének (Cox 1998), valamint a társadalmi tőke valamilyen formája megteremtését segítő eredményeknek.

Nan Lin (2001) a társadalmi tőkéről két szinten, az egyének és a csoportok szintjén gondolkodik. Az egyéni szintü társadalmi tőkét az egyéni élethelyzetekhez és 
szocializációs közegekhez, illetve egyéni cselekvőkhöz köti. Felfogásában a társadalmi tőke egyéni befektetés a társadalmi életbe a várt hasznok reményében. A csoport szintü társadalmi tőke esetében azt vizsgálja, hogy egyes csoportok hogyan termelnek és tartanak fenn több vagy kevesebb társadalmi tőkét. E csoportok esetében a társadalmi tőke kollektív vagyon, és ez az erőforrás különböző módokon van hatással a csoport tagjainak életkilátásaira.

John Field (2003) összefoglaló munkájában a társadalmi tőke három típusát mutatja be: az áthidaló (bridging), a megkötő (bonding) és az összekapcsoló (linking) társadalmi tőkét. A három változat különböző társadalmi csoportokban létrejött társadalmi tőkét jelöl, ezért keletkezésük főleg a csoport szintjén értelmezhető, birtoklásuk azonban már az egyén szintjén is. A megkötő társadalmi tőke olyan kapcsolatokat jelöl, melyek hozzánk hasonló, hozzánk közeli emberekkel köttetnek, mint a közvetlen család, közeli barátok és szomszédok. Az áthidaló társadalmi tőke sokkal inkább távolabbi kapcsolatokon alapul, mint a kapcsolat a kollégákkal, és ide tartoznak a gyengébb baráti szálak, kötődések is. Az összekötő társadalmi tőke olyan emberek kapcsolataiból áll, akik nincsenek benne a közvetlen közösségünkben, közvetlen hálózatunkban. Az ilyen kapcsolódásokon keresztül lehet a helyi közösség erőforrásainál szélesebb erőforrás bázishoz eljutni. A társadalmi tőke típusa természetesen befolyásolja annak hatását az egyénre és a társadalmi hálózatra egyaránt. Ezen különbségeket azonban nem minden, az elméletet alkalmazó kutató veszi figyelembe.

Eva Cox (1995) is ír a társadalmi tőke megjelenési formáiról. Szerinte fontos, hogy ne csak elérjünk egy bizonyos szintü társadalmi tőkét, hanem folyamatosan törekednünk kell annak folyamatos növelésére. Szerinte a következő elemek lényegesek a társadalmi tőke keletkezése szempontjából: 1. bizalom, önbizalom, interperszonális bizalom, bizalom a kormányban és az intézményekben; 2. reciprocitás; 3. tolerancia és különbözőség; 4. részvétel és együttmüködés; 5. valahová tartozás; 6. vita és megkérdőjelezés; 7. saját és mások értékeinek erősítése, fokozása; 8. szociális adottságok, lehetőségek (Cox 1995). Ezeken a területeken jelenik meg a társadalmi töke a társadalom életében, és határozza meg a különböző területek müködésének sikerességét.

Más szerzők azt hangsúlyozzák, hogy a bizalom, a szociális adottságok, az együttmúködés, a felismerés és a jóváhagyás a társadalmi tőke első számú komponensei, amik közvetlenül kapcsolódnak a részvételhez, az állampolgári elkötelezettséghez és a stabil demokráciához (Brehm-Rahn 1997; Stolle-Rochon 1998). Stone (2001) azt mondja, hogy a társadalmi hálózatok a társadalmi tőke strukturális 
elemét képezik. Ezekben a hálózatokban megtalálhatók a kölcsönösség és bizalom normái, amelyek mind a társadalmi tőke kulcsdimenziói. A szolidaritás fogalmát az azonnali viszonzás reménye nélküli reciprocitás tükrében szintén a társadalmi tőke elemének tekinthetjük (Utasi 2002b, 2008).

\subsection{TÁRSADALMI TŐKE, A KÖZ ÉS MAGÁNSZFÉRA}

A magán- és közszférák természetszerüleg hatnak egymásra, és sok feladat megoldásában, illetve közös érdekeik, érdekegyezések mentén együtt is müködhetnek. Ahogy az emberek mindkét „,színtérről” szereznek tapasztalatokat, miközben speciális dolgokat észlelnek és értékelnek ki, úgy használják majd ezen tapasztalataikat arra, hogy a különleges körülményeket értékeljék (Cox 1998.). Portela Maseda és Neira Gómez (2003) valamint Nan Lin (2001) is megkülönböztetik azt a társadalmi tőkét, amely az egyénekhez kötött, jobban kapcsolódik személyes célokhoz és hasznokhoz, illetve a közösségi társadalmi tőkét, ami szintén egyénekhez vagy egyének hálózatához kötött. A közösségi társadalmi tőke esetében azonban az egyének együttes munkája, kooperációjuk egy kollektív cél elérése érdekében zajlik.

A kettős megközelítést osztja Hartmut Esser (2008) is, aki szintén két típusát különbözteti meg a társadalmi tőkének: a viszonyokon alapuló, illetve a rendszer sajátosságaiból táplálkozó tőkét. A viszonyokon alapuló tőke az egyén kapcsolataiból, társadalmi kapcsolathálózatából ered. Az eltérő mérték oka ebben az esetben az egyén különböző hálózatokban elfoglalt pozíciója. A rendszer minőségétől függő tőke pedig a társadalom helyzete, a közbizalom szintje, illetve más fontos társadalmi adottságok által meghatározott. Ebben az esetben a makro környezet normái és állapotai határozzák meg a tőke elérhetőségét és mértékét.

Putnam és szerzőtársai (1993), illetve Wallis és szerzőtársai (1998) különbséget tesznek „lokalizált társadalmi tőke” (vagyis a megkötő társadalmi tőke) - ami a családon vagy a szük társaságon belüli informális szociális hálózaton alapszik, és erős bizalom jellemzi -, valamint az ,általánosított társadalmi tőke” közt (más néven áthidaló társadalmi tőke). Az áthidaló társadalmi tőke segít létrehozni az egyének és a szervezetek közti kapcsolatot, de ezek nincsenek szükségszerüen közel egymáshoz térben is. Wallis, Crocker és Schechter (1998) rámutatnak arra, hogy a társadalmi tőke mindkét típusa kapcsolatban van a polgári elkötelezettség normájával, és kimondják, hogy: 
„Az áthidaló töke ereje a helyi társadalmi töke áthidalásának erején nyugszik. Megforditva, a helyi társadalmi töke az informális társadalmi együttmüködések minöségén és intenzitásán nyugszik.” (258-259. o.)

Putnam és Goss (2004) a társadalmi tőke meghatározásakor nagy hangsúlyt fektetnek a társadalmi kapcsolatok erejére. A szerzőpáros megközelítésében egyrészt létezik egy erős kapcsolatokon nyugvó társadalmi tőke - ahol a kapcsolatok nagyon intenzívek, és az emberek nagyon közel állnak egymáshoz. Másrészt létezik gyenge kapcsolatokon nyugvó társadalmi tőke - ahol a kapcsolatok intenzitása gyenge, és az emberek nem állnak közel egymáshoz. A szoros és a gyenge kapcsolat is nagyon fontos szereppel bír a társadalmi tőke alakulásában.

Stone és Hughes (2002) a fent leírtakhoz nagyon hasonlóan kategorizálja a társadalmi tőkét, a társadalmi hálózatok természetére alapozva. Azt állítják, hogy a társadalmi tőke alapjai és típusai a hálózatok jellemzőinek (illetve ezen jellemzők kombinációjának) függvényében változnak, ahogy a kapacitások mértéke is. Az olyan zárt és sürü hálózatok, mint a család, barátok, szomszédok a „megkötő társadalmi tőkét" fejlesztik, vagyis azt a társadalmi tőkét, amely segít megismerni a speciális szükségleteket. A kiterjedt hálózatok, informális kötelékek (néha idegenek közt is) gondoskodnak a források és lehetőségek áramlásáról, ami a társadalmi tőkének széles alapot biztosíthat, fokozva az ,áthidaló társadalmi tőke” jelentőségét. Azok a kapcsolatok, amelyek egyrészt a formális szervezetek és a szakértők között, másrészröl az egyének és a társadalom között létesülnek, a „megkötő társadalmi tőkére" reflektálnak. Végezetül: a heterogén hálózatok befolyásolhatják az idegenek közti bizalmi szintet azzal, hogy a különböző csoportok közti kapcsolatok létrejöttét bátorítják, illetve gátolják ezen kapcsolatok kialakítását.

Putnam és Goss (2004) amellett érvelnek, hogy míg a társadalmi tőkének pozitív hatása van azokra, akik a hálókhoz tartoznak, addig negatívan hat a hálón kívüliekre. Stone és Hughes (2002) szintén azt mondják, hogy a hálózatok, a bizalmi normák és a kölcsönösség a társadalmi tőke lényeges elemein alapszanak. Ezt szem előtt tartva a bizalom három különböző fajtáját és a társadalmi kapcsolatok hálójának három kategóriáját különböztetik meg, különböző hálózatokhoz igazodva.

- informális típus/informális kapcsolatok

- általánosított típus/általánosított kapcsolatok

- intézményes típus/intézményes kapcsolat. 
Az első kategória megfelel a megalapozott kapcsolatoknak és a közeli barátok közti szociális kötődésnek. A második kategória leírja azokat a kötődéseket, amelyek ismerősök vagy a társaságon belüli idegenek között vannak, ahol a megosztott értékeknek és a részesedésnek fontos szerepe lehet a bizalom és a kölcsönösség fejlődésében. A harmadik kategória a közösség tagjai és intézményei közötti kapcsolatot írja le.

Elmondható, hogy a társadalmi tőkének van vertikális és horizontális típusa is. A vertikális az individuumok autoritáshoz és dependenciához való viszonyához kapcsolódik, ami hierarchia, egyenlőtlenség és hatalom formálisan strukturált kapcsolatain alapszik, ahogy az megnyilvánul a bíróknál, rendőröknél, tanároknál stb. A társadalmi tőke e fajtáját közösségen kívülinek (non-communitarian) is hívják, és nem feltétlenül foglalja magában a szociális részvételt, kölcsönösséget és reciprocitást. Putnam és szerzőtársai (1993. 170. o.) szavaival: „A [vertikális hálózat] nem tartható fenn bizalommal és együttmüködéssel.” Természetesen az élet több területén szükség van vertikális hálózatokra, például a munkahelyeken, ahol fönök nélkül aligha lennének tarthatóak a munkáltató által kitüzött célok.

A horizontális típus az egyenlő jogokkal és lehetőségekkel rendelkező állampolgárok által alkotott hálózatokban létezik, ez a közösségi társadalmi tőke. A bizalom, a szolidaritás és a reciprocitás társadalmi aktusai egyaránt horizontális hálózatot igényelnek a működésükhöz, mint ahogy a társadalmi tőke ebben a írásban tárgyalt többi eleme is. Horizontális hálózatként fogható fel például az egy munkahelyen hasonló beosztásban dolgozó kollégák köre, akik együtt dolgoznak, szolidárisak egymással, a bizalom magasabb szintje hozzájárul a hatékonyabb együttmüködéshez, így ezáltal használják ki a társadalmi tőke nyújtotta lehetőségeket. Horizontális hálózat továbbá maga a demokratikus társadalom is, hiszen minden polgárnak egyenlő politikai jogai vannak, melyekkel maga rendelkezik.

Úgy vélem, hogy a társadalmi életben a horizontális és vertikális társadalmi tőke egyaránt fontos építőkövek. Amennyiben a különböző politikai egységek társadalmi tőke szintjét kívánjuk megvizsgálni a demokratikus társadalmakban, kizárólag a horizontális elméleti megfontolást használhatjuk. Ez persze nem zárja ki, hogy egyes társadalmi csoportok vizsgálatakor hasznos lehet támaszkodni a vertikális társadalmi tőke elméletre, ebben a munkában azonban a horizontális megközelítés kap jelentős hangsúlyt. 


\subsection{A BIZALOM}

Francis Fukuyama (2007) úgy definiálja a bizalmat, mint elvárást, ami szabályszerü közösségben alakul ki, őszinte és együttmüködő viselkedést, ami a tagok közös értékein alapszik. Megjegyzi, hogy a társasági élet nem lenne lehetséges olyan közösségi értékek nélkül, mint a bizalom. Freitag (2003) azt mondja, hogy a társadalmi bizalmat a normák és értékek olyan csoportjaként kell tekintenünk, amelyben megvan a mások felé nyitás attitűdje, valamint a bizalomra való hajlandóság, s ezek a társadalmi tőke alapvető komponensei. A bizalom stimulálja a kölcsönösség környezetét és a kollektív cselekvést, ami arra bátorítja az embereket, hogy társadalmi kapcsolatokat teremtsenek, amik szintén kulcsfontosságúak a társadalmi tőke szempontjából. Keating (2001) rámutat arra, hogy a bizalom segít az embereknek úrrá lenni a nem-szimultán kölcsönösség problémáján. Cox (1995 és 1998) szintén kulcsfontosságú pontnak tartja a bizalom megteremtését és megerősítését a társadalmi tőke fejlődésének szempontjából. Cox a bizalom terminusát azoknak a kötelékeknek a kollektív elvárására érti, ami az embereket kötik össze, és személyes tapasztalatokon alapulnak, illetve amelyre a személyes tapasztalatok nagy befolyással bírnak. A bizalom felhalmozása jó dolog, szem előtt tartva, hogy a bizalom másokkal való kapcsolatunktól függ (egyénekkel, intézményekkel vagy a kormánnyal való kapcsolatunktól). Az épp megteremtett bizalom segít megalapozni az új kapcsolatokat, amelyek megerősítik, vagy lerombolják azt. Másképp a pozitív szociális kapcsolatok hiánya a szociális bizalom hiányában tükröződik, ami egyéni cselekvésre sarkallhatja az embereket, vagy arra, hogy elkerüljék a kollektív cselekvésekben való részvételt (Latham 1998).

Hollis (1998) úgy véli, hogy a szociális lények ezt a bizalmat a mindennapi életükben gyakorolják - az otthoni privát szféráikban, a barátaikkal, a családjukkal vagy idegenekkel, vagy a civil közösségben, a nyilvánosabb életterükben. Hollis megállapít három megközelítést, amelyek segíthetnek jobban átlátni a bizalom kérdéskörét. Ezek a megközelítések: 1. A társadalmi kapcsolatokat összetartó „erő” vizsgálata, 2. azon elemek meghatározása, amelyek a társadalmi kapcsolatokat erősítik, vagy gyengítik, végül 3. A közéleti szabályokat a társadalmi intézmények elvárásaihoz igazító képesség vizsgálata.

A bizalom a konszenzusból és a közös egyetértésből származik, ami megkönynyíti annak megértését, hogy valaki feladja a személyes döntéseit a kollektív tett és a közös haszon elötérbe helyezése miatt. Ebben az állapotban bonyolult, ha 
nem lehetetlen, hogy megállapítsuk, hogy melyik okozza melyiket. Fukuyama (2007) rámutat arra, hogy a kulturális tőke létezése kulcspont a bizalom fejlődése szempontjából. Azok a társaságok, amelyeknek nagy a kulturális tókéje, a szolidaritás megtapasztalásával magas szintủ bizalmat biztosítanak a maguk számára, ami az erkölcsös magatartás mintáján alapszik, illetve a csoporttagok által követett kölcsönös kötelességekben. Ugyanakkor a kulturális tőke szempontjából gyenge közösségek alacsony szociális kohéziótól szenvednek. Weiss (1996) szintén hangsúlyozza a megosztott kultúra szerepét (közös nyelv, hitrendszer, társadalmi viselkedés, társadalmi gazdasági osztály). Nagyon fontos, hogy figyeljünk az erkölcsi tradíciókra ható dolgokra (mint a kultúra) és azokra az intézményekre, amelyek „egyéni motivációs irányultságuk" felett állnak.

Brehm és Rahn (1997), Cox (1998), valamint Putnam és munkatársai (1993) támogatják az elképzelést a kölcsönösségi kapcsolatról, ami az állampolgári elkötelezettség és az interperszonális bizalom között van. Stone (2001) szintén egyetért abban, hogy a bizalom, ami alatt a társadalmi tỏke dimenzióját érti, a társadalmi hálózatokban rejlik, és szorosan összefügg a reciprocitás normáival. Tehát Stone (2001) azt mondja, hogy a hálózatok megváltoztatják típusaikat, és a bizalom, reciprocitás normái szintén kedvünkre variálhatók.

Cox (1995) állítja, hogy minél többet dolgozunk együtt másokkal egy együttmüködésre bátorító környezetben, annál inkább növekedni fog a bizalom szintje, és az esetenkénti bizalmi deficitek kevésbé lesznek károsak. Az ilyen, együttmüködésre bátorító környezetben történő munkavégzés esetén azt mondhatjuk, hogy a társadalmi tőkét fokozottabban használjuk.

Putnam (2000) is megállapítja, hogy a képzettségi szint és a társadalmi töke között szignifikáns kapcsolat áll fent. Az ő érvelése szerint azok az egyének, akik magasabb szintü oktatásban részesültek, magasabb szintủ bizalmat, toleranciát és magasabb szintü részvételt mutatnak az önkéntes és a formális együttmüködésekben. Weiss (1996) is arra a következtetésre jut disszertációjában, hogy a kapcsolatok szerepe az emberi tőke fejlődésében (például az oktatáson keresztül) és a társadalmi tőke fejlődése esetében összekapcsoltságot mutat. Egyrészt az emberi tőke igényli a bátorítást és azt, hogy a forrásokhoz csak közösségen belül lehessen hozzáférni annak érdekében, hogy a gyarapodás sikeres legyen. Másrészt a társadalmi tőke az emberi tökében bízik, mert a közösségeknek iskolázott individuumokra van szükségük, hogy támogassák és tanítsák másoknak azokat az értékeket (mint a bizalom), normákat, amik lényegesek a társadalmi tőke megteremtése és fejlódése szempontjából. Ebben az összefüggésben a munkanélküliség és az anyagi források 
hiánya bizalmatlanságot szül. A médiában és a közintézményekben szerzett tapasztalat szintén hatással van az egyéni bizalom szintjére, különösképp abban az esetben, ha egy demokratikus rendszer szociálpolitikai intézményei a civil társadalom és a közösségi élet önkormányzatának bázisai (Brehm-Rahn 1997).

Freitag (2003) úgy gondolja, hogy a társadalmi-gazdasági státusz (ami a jövedelmen és az oktatáson alapszik) erősen összefügg a szociális bizalom szintjével, ezért a társadalmi tökével is.

A bizalom komponensei alapján is kategorizálható. Cox (1998) megkülönböztet „szociális” bizalmat (közelebb áll az egyénhez és az idegenekkel való kapcsolatához) és ,állampolgári” bizalmat (ami jobban függ a normáktól és a formális intézményektől). Cox (1998) a bizalom mindkét típusáról úgy gondolkodik, amint az a társadalmi kapcsolatok, az emberek elégedettsége és a társadalmi rendszer minőségét vizsgáló felmérések általános kiindulópontja. Szerinte a bizalom az emberek elvárásainak összege, és egyben az a jellemző, amelyben az emberek társadalmi kapcsolataik tapasztalatait összegzik. Szerinte a magasabb fokú bizalom elvezet az elkötelezettséghez és odaadáshoz, ezáltal a társadalmi kapcsolatok kialakulásához.

Brehm és Rahn (1997), Stolle és Rochon (1998), valamint Utasi Ágnes (2002b) használják az „általánosított interperszonális bizalom” kifejezést, hogy leírják az ismerős kapcsolatokon túli bizalmat, ami megteremti a bizalmi körön kívüli emberekkel való együttműködés lehetőségét. Az általánosított interperszonális bizalom nagyban függ a társadalmi szabályok felé való elkötelezettségtől és az ezek követéséből fakadó tapasztalatoktól, és nagy befolyása lehet a közös cselekvés kialakítására. Portes és Sensenbrenner (1993) az „érvényesíthető bizalom” terminusát használják, ami az egyéni célok helyett a kollektív célok felé mutató egyéni motivációra vonatkozik.

Az általánosított interperszonális bizalom mérésével kapcsolatban megszokott módszer kérdőíves felmérésekben rákérdezni arra, hogy az emberek mennyire megbízhatóak, segítőkészek illetve érdeklődők a válaszadók véleménye szerint (BrehmRahn 1997). A bizalom növekedésével, illetve a közösségi ügyekhez és célokhoz való elkötelezettséggel kapcsolatban sok kutatásban felmerülnek azok a kérdések, hogy milyen gyakran találkoznak és keverednek az emberek és milyen célból. (Cox 1999) A részvétel kapcsolatban van a bizalommal: „minél inkább részesei az állampolgárok a közösségüknek, annál inkább megtanulnak bízni a másikban, és minél inkább bíznak az állampolgárok egymásban, annál inkább lesznek résztvevők" (Brehm-Rahn 1997, 1001-1002. o.). A mai társadalomtudomány bizalommal kapcsolatos elméleteinek nagy része úgy tartja, hogy a bizalom fejlődhet azáltal, hogy 
lehetőségeket teremtünk a másokkal való pozitív kapcsolat megtapasztalására (ismerősökkel vagy idegenekkel). Éppen ezért lehet az interperszonális és az intézményi bizalom mérése hasznos eszköz ahhoz, hogy feltárjuk az emberek meglátásait és attitủdjeit, például az életszínvonalról, illetve több más, külső társadalmi jelenségről (így a társadalmi tőkéről is, melynek csupán egy dimenziója a bizalom).

A bizalom és a társadalmi töke szintjére befolyással van a politikai környezet. A politikai rendszerbe, valamint az intézményekbe (és az általuk képviseltekbe) vetett bizalom szintje kapcsolatban van azzal az elgondolással, hogy a kormányzati rendszer problémamegoldó. Putnam és szerzőtársai (1993) rámutatnak arra, hogy a demokratikus társadalom állampolgárai hisznek abban, hogy joguk van megkérni az őket képviselő kormányt, hogy segítse egyéni és közös céljaik elérését. Az emberek elvárják a kormányoktól, hogy fogékonyak legyenek igényeikre, de legfőbbképp, hogy hatékonyan tegyenek az érdekükben, azaz értük. Putnam azt állítja, hogy a társadalmi tőke elősegíti a hatékony közpolitika megvalósítását, mely részben a magas társadalmi töke szint következménye is.

Eva Cox (1995) gondolatai alapján megállapítható, hogy a kormányba vetett bizalom, a közéleti részvétel és a közszolgálat kapcsolatban állnak a kollektív jóléttel és az általánosított társadalmi illetve intézményi bizalommal. A bünözés, drogfüggőség és munkanélküliség éppúgy hatással lehet az interperszonális bizalmi szintre, ahogy a kormányba vagy más szociális intézményekbe vetett bizalomra is.

Az emberek nagyon érzékenyek az egyenlő demokratikus jogok területén megjelenő egyenlőtlenségekre. A kormánnyal, intézményekkel és/vagy politikai szereplökkel szemben felmerülö bizalmatlanság és az egyenlötlenség együtt hatnak a közösségi bizalom és jólét szintjeire, és szintén rombolhatják a társadalmi tőkét (Cox 1995, 1998). Az államnak nincs közvetlen kapcsolata állampolgáraival és azok problémáival. Ez az elválasztás hatással lehet a bürokráciába vetett bizalom szintjére, illetve arra a vélekedésre, hogy a bürokratikus rendszer sikeresen meg tud-e oldani feladatokat, illetve képes-e fellazítani társadalmi konfliktusokat. A kormánnyal és a közintézményekkel kapcsolatos bizalomhiány közvetlen kapcsolatban az emberek közéleti aktivitásának és elkötelezettségének szintjével, illetve avval a hittel, hogy a szóban forgó közintézmények képesek lehetnek-e arra, hogy megoldják a problémáikat (Cox 1998).

Az intézményekbe és a politikai vezetőkbe vetett bizalom mérése (együttes vizsgálata azoknak az eseményeknek, amelyek hatottak az emberek kormányokkal, intézményekkel és közhivatalokkal szembeni bizalmára) nagyon érdekes a társadalmi tőke szempontjából. Stone (2000) ezzel szemben azt mondja, hogy bár 
az intézményes bizalom indikátorai hasznos információkat nyújtanak az állampolgárok közintézményekbe vetett bizalmával kapcsolatban, ám ezek az információk nem lesznek kizárólagos magyarázó értékủek, és nem feltétlenül segítenek megérteni a társadalmi tőke fogalmát, hacsak nem találunk empirikusan igazolható kapcsolatot az állampolgári vagy intézményes bizalom és az általánosított bizalom között. Hasonló véleményen van a bizalom tekintetében Bo Rothstein is, azt fejtegetve, hogy bár a skandináv államok polgárainak körében az 1980-as évek óta nagyot esett a politikusokba vetett bizalom, ez nem vonatkozik a szociáldemokrata vívmányként fennálló jóléti rendszerre, valamint a közigazgatás müködésére, melyek iránt még a 2000-es években is magas bizalom tapasztalható. A politikusok viselkedése, botrányai nem a mindennapi ember életterének eseményei, ám sokkal inkább ide tartoznak a közigazgatás, az iskoláztatás, a szociális ellátás szférájának müködéséről szerzett tapasztalatok. Ha az ember érzi, hogy az általa befizetett öszszegekből müködtetett rendszerek valóban hatékonyak, megmaradhat a beléjük vetett bizalma akkor is, ha a politikusok - vagyis a demokrácia emblematikus reprezentánsai - nyilatkozatai vagy cselekedetei iránt gyakran nemtetszését fejezi ki (Rothstein 2004). Uslaner és Badescu Rothstein írására reagálva ugyanakkor kifejtik, hogy bármilyen csábító is Rothstein optimizmusa, illetve hite abban, hogy az emberek egy demokráciában maguk alakítják ki a szervezeteket és ezen keresztül a közbizalmat - tehát nem a történelmi örökség vagy a „sors” által determinált dolog a bizalom léte vagy elenyésző mivolta - e vélemény mégiscsak a skandináv állapotok, a letisztultabb demokrácia talaján sarjad, így nem adaptálható univerzális módon akárhová. Romániában például, állítja a szerzőpáros empirikus adatok vizsgálata nyomán, a társadalmi tőke kialakulása vagy hanyatlása más mintázatot mutat. 51 országot vizsgálva arra találtak bizonyítékot, hogy a legkevésbé korruptak, vagyis bizalomrombolók a skandináv országok, míg a kelet-európai, az egykori szovjet érdekszférába tartozó országok a korrupcióval nagymértékben fertőzöttek közé tartoznak. A korrupciót - vélik a szerzők - nem a román emberek tartják életben, hanem arra kényszeríti őket a rendszer (a közigazgatásban, az igazságszolgáltatás terepén, az egészségügyben, stb.), hogy fenntartsák. A "fejétől büzlik a hal"- elvet vallják, és ha elégedetlenek a kormányzattal és a politikusokkal, akkor és a célok törvénytelen eszközökkel való elérésének, mint egyetlen lehetőségnek a létével is elégedetlenek, mellyel ennek ellenére élni kénytelenek. A román lakosok elsősorban nem egymással szemben bizalmatlanok, hanem a közigazgatási és jóléti rendszerrel szemben azok, ezért ha biztosak akarnak lenni az ügyintézés sikerében, automatikusan nyúlnak olyan eszközökhöz, ami a skandináv 
polgároknak eszébe sem jutna, minthogy egy jól müködő állam alacsony korrupciós szintủ lakosai. Románia tekintetében tehát a politikum iránti antipátia nem párosul a közigazgatásba, az egészségügybe vagy az igazságszolgáltatásba vetett bizalommal (Uslaner-Badescu 2004).

Az intézményekbe és politikusokba vetett bizalom tekintetében inkább értek egyet Uslaner és Badescu empirikusan is alátámasztott elméletével, mely sokkal inkább leképezi a polgárok által magába a társadalomba vetett bizalom szintjét. Ha a társadalmi élet jól müködik, és az általános bizalom szintje magas, az emberek bízni fognak a társadalmi intézményekben is. Ugyanez az állítás kijelenthető fordítva is: a magas mértékü általánosított bizalom magasabb mértékü bizalmat fog hozni az intézmények és politikusok számára egyaránt. A bizalom megléte kiemelt fontosságú a társadalmi élet minősége és a társadalmi integráció megteremtődése szempontjából (Utasi 2008).

Osztom Stone elképzelését azzal kapcsolatban, hogy az intézményekbe vetett bizalom és az általánosított bizalom esetében meg kell vizsgálni, alkalmasak-e együttesen vagy külön-külön a társadalmi töke szintjének jelzésére. Cox gondolataival is egyetértek, miszerint a bizalom típusai kapcsolatban vannak a kollektív jólét mértékével és ezáltal a társadalmi tőkével. Véleményem szerint az állampolgárok a társadalmi tőke környezetükben tapasztalható szintjéből, konkrétan például a társadalmi élet minőségéből indulnak ki akkor, amikor eldöntik, hogy megadják-e a bizalmat illetve megkérik-e a bizalmat a többi embertől illetve a társadalmi intézményektől. Az általánosított bizalom esetében ezt mindenképpen feltételezem, az intézményes bizalom esetében azonban csupán empirikus próbák elvégzése után tartom igazolhatónak. Szerintem a bizalom különböző típusai különböző társadalmi közegekben létezhetnek. Kutatásomban a magyar társadalom, illetve a magyar régiók helyi társadalmai esetében fogom megvizsgálni az általánosított és az intézményes bizalom jelenlétét, mértékét, esetleges invarianciáját, illetve fel fogom mérni a két bizalomtípus vizsgálata által a társadalmi tóke feltételezhető szintjét.

\subsection{RECIPROCITÁS}

A reciprocitás társadalmi jelenségét elméleti rendszerébe először Polányi Károly építette be (1944/2004). A modern, önszabályozó piac születésével függ össze a reciprocitás kialakulása, és része annak a folyamatnak, amikor a piac irányításában 
a gazdaság szerepe felértékelődik, és a társadalom szabályozó szerepe lecsökken. Polányi szerint a 19. század előtt a társadalom volt a domináns szereplő a piac irányításában, ám ezt a szerepet később átvette tőle a gazdaság.

Stone (2001) írásában a társadalmi tőke kiemelt fontosságú elemeként mutatja be és az alábbi módon jellemzi a reciprocitást: „... egy olyan átváltási folyamat a társadalmi kapcsolatokon belül, ahol a »árucikkek és szolgáltatások « (azaz tágan értelmezve bármilyen átváltási folyamat) az egyik szereplő által visszafizettetnek egy másik szereplőnek, méghozzá annak a szereplőnek, amelyik az eredeti - „árucikkeket és szolgáltatásokat« elfogadta. A kölcsönösségi kapcsolatokat normák irányítják, így azokat az érdekelt feleket is, akik megértik, hogy egyféle társadalmi szerződést részesei lettek." (36. o.)

Stone és Hughes (2002) három részre osztja a reciprocitás társadalmi intézményét: az informális, általánosított és intézményi reciprocitásra. Az informális reciprocitás a családi és baráti kapcsolatok reciprocitása, amely erős kapcsolatokon alapul. Fontos jellemzője az egyén barátainak száma, a család nagysága és a fenntartott kapcsolatok intenzitása. Az általánosított reciprocitás kiterjed a szélesebb társadalomra, azaz minden emberre, akivel az egyén kapcsolatba kerül, és az általánosított bizalommal rokonítható. Az intézményi reciprocitást az intézményekbe vetett bizalom jelenségével köthetö össze, és föleg a társadalom nyilvános alrendszereiben tekinthető múködőképesnek.

Az egyéni kapcsolatok alapján a hálózatok típusai hatnak a kölcsönösség normáinak attribútumaira (Stone 2001). Putnam és szerzőtársai (1993) rámutatnak, hogy az általánosított kölcsönösség normái hatnak a közösség tagjaira, és a szociális hálózatoknak szerepük van a szociális bizalom megteremtésében, ezért fontos komponensei a társadalmi tőkének. Megállapítják, hogy az emberek szívesebben köteleződnének el a kollektív tettek mellett, ha biztosítanák őket arról, hogy a közremüködésüknek valamiképp meglesz a jutalma. Selznick (1998) rámutat, hogy az egymásrautaltság és a kölcsönösség a közösség létezésének alapelemei, és mindkettő segít fejleszteni a közös célok, haszon és bizalom érdekében való önkéntes együttmüködést. Bellah (1998) amellett érvel, hogy a demokratikus társadalmi körülmények között zajló élet szempontból a reciprocitás, a lojalitás és a közös haszon érdekében való együttmüködés normáival rendelkező kapcsolatok az egyéni és a szociális jólét alapelemeinek tekinthetőek.

A közös elvárások és célok azonosítása lényeges a kooperációt és a reciprocitást előidéző érzések kialakításában. A közös elvárások és célok sikeres azonosítása kihat a személyes szintre és a kollektív szintre egyaránt, illetve az ellenőrzés 
szintjére (a személyes vagy kollektív körülmények felett). Hat továbbá az ezekért a célokért való kollektív társadalmi cselekvési folyamatba vetett bizalomra (Cox 1998).

A reciprocitás mérése a hálózaton belüli kölcsönös csere indikátorait foglalhatja magában, amik nagyban változhatnak a hálózat típusától függően, amiben fejlődtek. Egy másik - a kölcsönösség normáinak leírására irányuló - megközelítés szerint le kell mérnünk a nem-kölcsönös magatartást és pl. Az adócsalás vagy a szállítási díj fizetésének elkerülése ellen hozott büntető szankciókat (Stone 2001). Ezek az indikátorok hasznos információkat adhatnak, ha a bizalmi indikátorokkal együtt elemezzük őket a hálózatokban.

\subsubsection{Szolidaritás - reciprocitás azonnali viszonzás nélkül}

A szolidaritás fogalma magába foglalja az Emile Durkheim (1893/1986) által mechanikus (tradicionális társadalmakra jellemzö), illetve organikus (modern társadalomra jellemző) szolidaritásnak nevezett koncepciókat. Utasi Ágnes a társadalmi integráció jelenségét vizsgálja a szolidaritás-elméletek segítségével. A modernitás keretei között a társadalmi integráltságot tekinti ideális állapotnak. A szolidaritást kiemelkedően fontosnak gondolja a társadalmi integráció megteremtődése szempontjából. Olvasatában a társadalmi integráció két módon képződhet. Létrejöhet például értékek hasonlósága alapján, mely esetben a szükséges társadalmi kohéziót az értékhasonlóság teremti meg. Másik lehetséges képződési helye a hatalmi - gazdasági - munkamegosztási viszonyokból származó érdek - ebben az esetben a kohéziót az érdekegyezés szolgáltatja. Álláspontja szerint a társadalmi integráció a gyakorlatban a szolidaritás-akciókon keresztül müködik. Kéttípusú motivációt feltételez a szolidaritás mögött, melyek közül az egyik érték, a másik érdek alapú, azonban a konkrét cselekedetek mögötti motivációk általában a kettő keveredéséből tevődnek össze. A modern társadalmakban is fontosnak gondolja a családi kapcsolatok szerepét a társadalmi integráció megteremtésében (Utasi 2002a, 2002b).

Véleményem szerint a szolidaritás elmélet hasonló szerepet tölt be, más fókuszpontokkal, mint a társadalmi tőke elmélet a társadalmi integráció, illetve a társadalmi hálózatok müködésének magyarázata szempontjából. A szolidaritás elemeinek tételezett bizalom, társadalmi kapcsolathálózati kötések egyaránt megjelennek a társadalmi tőke elemei között. A szolidaritást ebben a munkában én az 
azonnali viszonzás reménye nélküli reciprocitás kategóriájába sorolom be, követve ezzel Eva Cox (1995) elgondolását a társadalmi tőke elemeivel kapcsolatban.

\subsection{TOLERANCIA}

A tolerancia egy olyan attitüd, ami több ponton kapcsolódik az általánosított bizalomhoz, a kooperatív magatartáshoz, a reciprocitáshoz és a társadalmi tőkéhez (Cox 1995, 1998; Stolle-Rochon 1998).

A nagyobb mértékű társadalmi tőkével rendelkező társadalmak nyitottak a diverzitásra és a különbségekre. A növekvő bizalmi szint megengedi az egyéneknek és a csoportoknak, hogy fejlesszék a toleranciájukat, mert szükség van a különbségek és az eltérő vélemények elfogadására (Cox 1995, 1998), valamint arra, hogy befogadjunk ismeretlen embereket egy már létező interakciós hálózatba (Stolle-Rochon 1998). Az emberek különböző nézőpontokkal rendelkeznhetek a közügyekröl. A véleménykülönbségeket az erös társadalmi tőkével rendelkező társadalmak elfogadják, és az ellenkező véleményen lévő vagy máshogy gondolkodó emberekkel szemben toleranciát mutatnak (Putnam et al. 1993).

Ennek ellentéteként azt mondhatjuk, hogy az emberek félhetnek a többi állampolgár törvényhez vagy közösségi szabályokhoz viszonyuló attitüdjétől és attól, hogy azok magatartása hathat rájuk. Ez a félelemérzet kárt okozhat a közösségi bizalom szintjén, ami tükröződhet a társadalmi részvétel alacsonyabb szintjében is (Cox 1995, 1998). A tolerancia erősítésével ez a negatív hatás leküzdhető.

\subsection{TÁRSADALMI HÁLÓZATOK}

A társadalmi hálózatok a társadalmi tőke keletkezési és egyúttal felhasználási helyei. A társadalmi hálózatok, amelyeknek az egyén tagja adják a társadalmi tőkéjét, illetve a társadalmi hálózatok maguk is birtokolhatják a tőketípust. A társadalmi hálózatok nélkül nem képződne társadalmi tőke. Stone (2001) szerint a társadalmi kapcsolat hálózatok a társadalmi tőke alapvető szerkezeti elemei, és a bizalom és a kölcsönösség normái jellemzik őket. A szociális hálózatok számos típusa létezik, s ezek méret, kapacitás, helyzet, struktúra és a magukban foglalt kapcsolatok 
természete szerint változhatnak. A hálózatok jellemzői hatnak az általuk megtermelt társadalmi tőke szintjére és típusaira (Stone-Hughes 2002.).

Stone (2001), valamint Stone és Hughes (2002) a társadalmi hálózatok használatát javasolják a társadalmi tőke mérésére, ahol az adott szociális hálózat normáit és jellemzöit is figyelembe kell venni. Ebben a megközelítésben a társadalmi hálózatok lehetnek informálisak (azok a hálózatok, amelyek családi, baráti és szomszédi kapcsolatokon alapulnak) és formálisak (azok a hálózatok, amelyek nem-csoport és csoportalapú kapcsolatokon, illetve önkéntes társaságokon és intézményeken alapulnak). A társadalmi kapcsolathálózati megközelítést alkalmazza Csizmadia Zoltán (2008) is társadalmi tőkéről szóló átfogó tanulmányában a tőketípus alaposabb bemutatásához. A következő alpontokban a társadalmi hálózatok néhány típusát fogom bemutatni.

\subsubsection{Család és barátok}

Az első hálózat típus a családi és baráti kapcsolatok hálózata. Coleman (1988) azt mondja, hogy az egyének azért teremtenek társadalmi tőkét, mert azt hiszik, hogy a társadalmi csoportok és hálózatok létrehozásával megkönnyítik a kollektív cselekvést, és ezáltal maximalizálják egyéni potenciáljukat és lehetőségeiket. Ebben a kontextusban Coleman feltárja a társadalmi tőke szerepét, mint forrást a gyerekek családon és közösségen belüli oktatásához és képzéséhez. Vitatja, hogy a családon belül kifejlődött kapcsolatok alakítanák a család társadalmi tőkéjét. A háztartásban a szülők fizikai jelenléte, a gyermek, szülőktől kapott figyelmének mennyisége és minősége, valamint a gyermek és a szülők közti kapcsolat erőssége fogja meghatározni a társadalmi tőke természetét családi szinten.

Stone és Hughes (2002) írja, hogy a társadalmi tőke egyik fontos megjelenési helye a családon belül van. Stone (2001) leírja, hogy a gyerekek közti kapcsolat és a kapcsolatok különböző rendszere csak pótlólagos mérőeszközei lehetnek a családon belüli társadalmi tőkének akkor, amikor a szülök távol vannak a háztartástól. Azaz a család társadalmi tőkéje csak a szülők személyes társadalmi tökéjével együtt értelmezhető, arra épül.

Weiss (1996) állítja, hogy a családon belül létezhetnek különböző összekapcsoltságok, amelyek a személyek közötti társadalmi távolságot és az elérési utak számát határozzák meg. Ezek az összekapcsoltságok a szerkezettől (egyedül álló szülő vs. mindkét szülö), az erőtől (szoros vs. gyenge kapcsolat) és a családtagok 
polgári elkötelezettségétöl függhetnek. Weiss nézőpontjából a családi kapcsolatok tradicionálisan segítik a bizalom magasabb szintű fejlődését és a társadalmi tőke szélesebb körben való elterjedését.

Azok a kapcsolatok, amelyek a családon belül jöttek létre és fejlődtek ki, meghatározó szerepet játszanak a mások iránti bizalom, a reciprocitás és az átváltás normáinak kialakulásában és ezért a társadalmi tőke növelésében is (Utasi 2002b, 2008).

A családon belül alakulnak ki az első ún. „erös kötések” (Granovetter 1973), amelyek az egyén közvetlen kapcsolataival kötődnek, így a családtagokkal és barátokkal. Az ilyen erős kötéseken alapuló kapcsolatok fenntartása sok energiát emészt fel. Az ilyen típusú kapcsolatok fontosak és hasznosak, ám fenntartásuk költséges, míg a felszínesebb kapcsolatok gyenge kötései nem igényelnek nagy energia-befektetést a fenntartásukhoz, és szintén hasznosak lehetnek tulajdonosaik számára. Ezzel azonban nem szeretnék érvelni a család, mint kapcsolati színtér és társadalmi intézmény ellen. Csupán fel szeretném hívni a figyelmet arra, hogy a társadalmi tőke szintje akkor tekinthető jobbnak, ha egyaránt alapul erős és gyenge kapcsolatokat implikáló kapcsolathálózati tagságokon.

\subsection{2 Önkéntes szervezetek}

Az önkéntes szervezetek társadalomtudományi elméletének egyik megalapozója Max Weber (1910/1987). Az önkéntes szervezet Weber elgondolása szerint olyan szervezet, amely az önkéntes módon csatlakozott tagjai felett fennhatósággal rendelkezik, és általában egy szük csoport irányítja. Minden esetben rendelkezik racionálisan meghatározott szabályokkal, racionális módon épül fel. Müködésének célja lehet a kollektív cselekvés elősegítése, egyaránt müködhet célracionális és értékracionális módokon. Ezeken az alapokon tehát fontos színtere a társadalmi tőkeképződésnek.

Az önkéntes szervezetekben való részvétel igen komoly szerepet játszik a társadalmi kapcsolatok alakulásában. Putnam (2000) elméletének formálódásában az önkéntes szervezetek tagságában történő amerikai visszaesés komoly szerepet játszott. A közösségi élet visszaesésének illusztrálására az önkéntes szervezeti szféra statisztikáit is felhasználta a szerző.

Egy másik észak-amerikai szerző, Robert Bellah (1998) szerint az önkéntes szervezeti részvétel nem jog, hanem kötelesség a társadalom pozitív irányba 
történő fejlesztése érdekében. Az önkéntesség véleménye szerint része az amerikai életformának, és hozzájárul a társadalom egészségességéhez. Szerinte az önkéntes szervezeti részvételben komoly meghatározó a szocializáció, és kiemelkedő a vallás szerepe.

Eastis (1998) azt mondja, hogy az önkéntes szervezetek változatosak, ezért különböző jellemvonásokkal (úgymint a tagok háttere, célok, képességek stb.) és különböző struktúrákkal bírnak, melyek mindegyike kihat szociális interakciójukra és a társadalmi tőketermelésükre.

Magyarországon az önkéntes szervezetekről elmondható, hogy a magánszemélyek által alapított egyesületek és alapítványok jelentős szerepet játszanak a társadalom életében. A rendszerváltás után a szervezetek számának növekedése nagymértékủ volt, napjainkra azonban beállt évi 3-4 százalékos szintre. Az önkéntesség fogalma a magyar civil társadalom esetében is a társadalmi tőke elmélettel hozható kapcsolatba (Bartal 2005). Tanulságként vonható le, hogy bármilyen önkéntes társuláshoz való tartozás alapeleme a társadalmi tőke fejlődésének.

\subsection{KÖZÖSSÉG ÉS TÁRSADALMI TŐKE}

Onyx és Bullen (2000) rámutatnak arra, hogy a társadalmi tőke létrejöttéhez és növekedéséhez a közösség tagjainak részvételét igényli. Hangsúlyozzák, hogy a közösségi elméletek hatással vannak a társadalmi tőke fogalmi fejlődésére:

„A bizalom, a hálózatok, a normák és a reciprocitás együttes hatása erös közösséget teremt, ami együttesen, közvagyonként birtokolja a forrásokat. ... A közvagyon a közösségbe ruházott forrásként értelmezendö, amit senki nem birtokol, de mindenki használ." (Onyx-Bullen 2000. 25. o.)

Weiss (1996) hangsúlyozza a közösség - ez alatt a családi, szomszédi, baráti kapcsolatot érti -, valamint közös értékeinek hatását a tagjai közötti szociális kölcsönhatásra és ezért a társadalmi tőke megteremtésére. Úgy véli, hogy a társadalmi tőke szintjei nagymértékben változnak közösségről közösségre, az „összekapcsoltság” vagy a tagok szociális interakcióinak mennyisége és minősége alapján.

Bellah (1998) támogatja a társadalmak olyan értelmezését, ami nem egyedül az individuumok, de a közösségek alapján írja le a társadalmat, követve a „demokratikus közösségiség” elméletét. Ez az elmélet azt mondja ki, hogy az egyének a 
közösségtől függenek, aminek az ereje a közös értékekből és célokból ered, valamint a közjó kutatásának kihívásából. Elmélete ugyanakkor markánsan épít az amerikai individualizmusra, amelyik az Egyesült Államok társadalmi tókéjének egyik meghatározó eleme.

\subsection{A TÁRSADALMI TŐKE MÉRÉSE}

A társadalmi tőke többdimenziós fogalom, amit széles körben használnak társadalmi, gazdasági és antropológiai kutatások alkalmával, csakúgy, mint a közérdek formálásakor és végrehajtásakor. A fogalom definiálásakor különböző diszciplínák kerülhetnek elő, és ezért különböző komponensek alkotják a mértékek és szintek vizsgálatának sorát. Stone (2001) amellett érvel, hogy a társadalmi tőke lényegében olyan fogalom, ami, bár széles körben használt, részben többértelmü és zavaró, mert nem tisztázott, hogy mi is az és hogyan is mérjük. Portela Maseda és Neira Gómez (2003) szintén azt mondják, hogy a társadalmi tőke többdimenziós fogalma megnehezíti, hogy egyetemes és állandó indikátort állapítsunk meg.

Stone (2001) három kritériumot javasol a társadalmi tőke indikátorainak kijelöléséhez:

„,...elöször is fel kell ismernünk, hogy a társadalmi töke többdimenziós fogalom, ami a társadalmi hálózatokkal, a bizalom normáival és a reciprocitás normáival jellemezhetö; másodszor meg kell értenünk, hogy a társadalmi töke valójában a tettek forrása; és harmadszor tapasztalatok alapján különbséget kell tenni a társadalmi töke és az eredményei között.” (55. o.)

Grootaert (1998) szintén javasol néhány kritériumot a társadalmi tőke indikátorainak kijelöléséhez és alkalmazásához. Először is ezeknek ugyanabból a fogalmi és operációs szerkezetből kell származniuk. Másodszor a társadalmi tőke indikátorait világosan kell definiálni. Harmadrészt az indikátoroknak mérhetőknek kell lenniük az olyan társadalmi jelenségekben, mint a háztartási, közösségi és nemzeti szintek. Végül objektívnek kell lenniük. Grootaert (1998) rámutat arra, hogy alapvetően két ösvényt lehet követni a társadalmi töke indikátorainak és eredményeinek kiválasztásánál. Az első út a különböző társadalmi kapcsolatok jellemzőitől és tényezőitől indul, és magában foglalja azok hatását és hatékonyságát. Ebben a perspektívában a helyi társulások és hálózatok típusa és mérete (tagság), a hálózat/ 
társulás belső homogenitása, a bizalom (interperszonális és intézményi) és a normákhoz való hűség lehetnek a társadalmi tőke indikátorai. A második út magában foglalja azokat az eredményeket és hatásokat, amelyeket a társadalmi tőke kifejthet a különböző dimenziókra (pl. gazdasági növekedés). Az olyan indikátorok, mint a politikai stabilitás, a polgári szabadság, a politikai korrupció és a kormány szakszerütlenségének szintjei, a szavazók sokasága, a diszkrimináció és a szociális széthullás a társadalmi tőke számos dimenzióra való hatására engednek következtetni.

Amikor a társadalmi tőkét mérjük, emlékeznünk kell arra, hogy a társadalmi tőke felhalmozott mértékei csak az adott populáció által képviselt összefüggésekre érvényesek, máshol ezek az indikátorok nem megbízhatóak. Ezért a társadalomkutatóknak nem szabad a társadalmi tőke felhalmozott mértékeit a társadalmi források egyetemes mértékének tekinteni (Edwards-Foley 1998).

Számos szerző úgy tekinti az interperszonális bizalmat, a szociális hálózatokat és a kollektív cselekvéseket, mint a társadalmi tőke kulcskomponenseit. Munkámban ezt a megközelítést adaptáltam, mivel az elméleti és empirikus bizonyítékok alapján a kapcsolat a fenti dimenziók, a társadalmi tőke és a társadalmi integráció foka között közvetlennek és egyértelműnek tünik. A társadalmi tőke operacionalizálása azonban nem egyszerű feladat, és mivel maga az elmélet már lassan metaelméleti szintre emelkedett, ezért csupán egyes dimenzióinak az operacionalizálása lehetséges. A fentebb idézett szerzők véleményét kutatási eredményeim alapján osztva a társadalmi tőkét csupán indikátorok szintjén lehet mérésre vagy másodelemzésre operacionalizálni, az elmélet teljességével kapcsolatban minden ilyen kísérlet hiábavalónak tetszik.

\subsection{A TÁRSADALMI TŐKÉRE VESZÉLYES TÉNYEZŐK}

A társadalmi tőke, a többi tőketípushoz hasonlóan felhalmozható, és el is veszthető. Ezt a tőketípust azonban, amennyiben a szintje csökken, sokkal nehezebben lehet újra növelni. Azt mondhatjuk, hogy a társadalmi töke olyan vagyon, amit könnyü lecsökkenteni és nehéz újjáépíteni (Grooaert- Van Bastelaer 2002). Egyik hétköznapi példaként hozható Putnam (1995) meglátása az amerikai társadalomból. Kutatásai bebizonyították, hogy a gyakori tévénézés fenyegetően hat az állampolgári elkötelezettség és a társadalmi bizalom megteremtésére és fejlesztésére, ezért a társadalmi tőkére is. Amíg az emberek tévét néznek, nem vesznek részt 
az otthonukon kívüli társadalmi tevékenységekben. Másként mondva a tévénézés kedvezőtlen lehet az önkéntes társaságokban való részvételre, így gátolhatja a szélesebb közösségben a társadalmi tőke megteremtését. Putnam és Goss (2003) szintén azt mondják, hogy a technikai fejlődés - telefon, e-mail stb. - kettős hatással van a társadalmi tőkére: egyrészt segítheti az emberek közötti kapcsolatok számának növekedését, másrészt az ellenkezőjét is kiválthatják.

Cox (1995) azt állítja, hogy az izoláció, a társadalmi kölcsönhatás hiánya és/ vagy a bizalmi kapcsolatok fejlődésének nehézsége, valamint a szociális érintkezések idejének és terének a hiánya fenyegetően hatnak a társadalmi tőke kialakulására és fejlődésére. Nézőpontja szerint a családi és az intim szociális kapcsolatok önmagukban nem forrásai a társadalmi tőkének. Ellenben behatárolhatják az önkéntes és szabad kapcsolatokat másokkal (a közeli és privát szférájukon kívüliekkel), ezáltal pedig behatárolhatják az egyének szociális képességeinek fejlődését, így kockáztatják a társadalmi tőke szélesebb közösségben való megteremtését.

Cox elméletében sajátos vonás a munkáról írt véleménye. Elgondolása szerint senkinek nem volna szabad napi nyolc óránál többet dolgoznia, hiszen ennél több időben valóban produktív munkát végezni szinte elképzelhetetlen, és azok az emberek, akik mégis többet dolgoznak, mások elől veszik el a munkalehetőséget. A társadalmi tőkéhez köthető érvelése ugyanezzel a jelenséggel kapcsolatban azonban meggyőzőbb, mivel azt írja, hogy akik napi nyolc óránál többet fordítanak munkavégzésre, valójában saját társadalmi tőkéjüket rombolják le, és egyúttal kárt tesznek társadalmi kapcsolathálózatukban is. A túlmunka egyúttal stresszhez és egészségügyi problémákhoz is vezethet, amelyek szintén negatív következményekkel járnak (Cox 1995, 1998).

Cox véleménye a túlmunkával kapcsolatban egybevág a Robert D. Putnam által vezetett „Better Together” („Jobb Együtt”) kampány egyik szlogenjével, amely arra hívta fel az amerikaiak figyelmét, hogy napi tíz perc ingázás milyen súlyos veszélyekkel járhat társadalmi tôkéjükre, életükre, és ezáltal kihathat akár az egészségükre is.

A mobilitás különböző típusai is veszélyt jelenthetnek a társadalmi tőkére, különösen a falusiból a városi környezetbe költözés, mely csökkentheti a falusi helyi közösségek számát, veszélybe sodorva azok létét. A városi környezet pedig nem biztosítja a szükséges feltételeket ezen közösségek újjáteremtésére (Grootaert 1998).

Hollis (1998) magát a bizalmat látja egy a hosszú távon potenciálisan fenyegetést jelentő intézményként a társadalmi tőkére. Rámutat arra a pozitív jelenségre, 
miszerint a bizalom magasabb szintjei a társadalomi tőkét, így a társadalmi integráció előrehaladását és fejlődését szintén magasabb szintre juttatják. Szerinte a haladás a felelős azért, hogy az emberek racionálisabbak, következetesebbek lettek, és a kapcsolataik sokkal müvibb módon alakulnak ki és kerülnek ápolásra. A kapcsolatok művibb módon alakulását tekinti negatív, potenciálisan a bizalmat és ezáltal a társadalmi tőkét fenyegető fejleményként. A kapcsolatok müvibb módon alakulása hosszú távon azt eredményezheti, hogy az emberek kevésbé fognak bízni egymásban, és talán kevésbé fognak megbízhatónak tünni.

Mivel a mai kor emberei sokkal gyorsabban és könnyebben léphetnek kapcsolatba egymással, ezért a kapcsolatok értéke bizonyos szempontból devalválódott. Az ismeretségek típusai és mélysége fogja meghatározni a kapcsolatok minőségét. Amennyiben egy kapcsolat hosszú történetre nyúlik vissza, és valamilyen társadalmi szempontból elfogadott módon jött létre, értéke nagy lesz, és nem is lesz egy lapon említhető például azokkal a kapcsolatokkal, amelyek egy névjegykártya csere által jöttek létre. Mindkét kapcsolat hasznos azonban a társadalmi tőke szempontjából, de a második, nem organikus módon keletkezett kapcsolat egyben veszélyezteteti is azt, mivel nagyobb mértékben benne van a meg nem adott bizalom veszélye.

\subsection{A TÁRSADALMI TŐKE NEGATÍV ASPEKTUSAI}

Ahogy arra már rámutattunk ebben a fejezetben, a társadalmi tőke nem egy, hanem többdimenziós jelenség. Ezek közül néhány dimenzió vitathatatlanul növelheti a társadalmi egyenlőtlenségeket. Portes $(1998,2$. o.) úgy fogalmaz: „... [a társadalmi tőke] fogalma a társas hajlam pozitív következményeire fókuszál, miközben félreteszi a kevésbé vonzó velejárókat”. Amíg a kollektíván belüli normák és hálózatok erősíthetik a hasznot hozó tevékenységeket, addig korlátozzák is azokat, ezért káros hatásaik lehetnek (Coleman 1988; Grootaert 1998; Portes 1998). A bizalmatlanság és az elöítéletek következményeként a diszkrimináció és a szegregáció a merev és szigorú szociális kötelékekből eredeztethetők, amelyek akadályozzák az integrációt, különösképp a vertikálisan strukturált közösségi hálózatokban. A normák és a szociális kapcsolatok (amelyek kooperációra jogosítják fel a tagokat, hogy hasznot hozzanak, illetve profitáljanak a tetteikkel) ugyanazok, amelyek kizárják a kívülállókat ebből a haszonból (Portes 1998; Portes-Landolt 1996), erőltetik a potenciális produktív interakciókat, ezáltal komoly konfliktusukat okoznak 
(Grootaert-Van Bastealer 2002). Például a szervezett bünözés és az utcai bandák esetében az erőszak és a bünözői magatartás normaként és értékként jelenik meg, és a bünszervezetek tagjai, akik egymáshoz nagyon lojálisak, még jutalmazzák is ezen normák és értékek megtartását. Ez a fajta társadalmi tőke a társadalmi integráció szempontjából egyáltalán nem hasznos. A tőkének ez egy az össztársadalmi normáktól és értékektől eltérö normákra és értékekre épülő, negatív formája (Weiss 1996).

Néhány esetben a közösségre jellemző apátia lehet a normája egy szük csoportnak vagy hálózatnak. Ez az apátia hozzájárulhat ahhoz, hogy csökkenjen a szolidaritás mértéke a közösség tagjai között, a viszonyokból pedig eltűnjön a reciprocitás és a tolerancia. Ekkor a társadalmi tőke egy dimenziója meggátolhatja egy vagy több másik dimenzió kialakulását (Weiss 1996). Ilyen jellegü hatásai lehetnek bizonyos közösségeknek vagy csoportoknak, amelyek a „normális” társadalmi rendet tekintik elvetendőnek, és attól próbálnak eltérően viselkedni. Példaként lehet felhozni a vallási közösségek közül a szociológiai értelemben vett szekták (Török 2004) esetét, amik sok esetben szélsőséges vallási tanításokat, normákat és értékeket terjesztenek tagjaik körében. Előfordultak például olyan szekták, melyek tagjaikat kizsákmányolták, öngyilkosságra, vagy a fennálló társadalmi rend elleni támadásokra késztették. A szociológiai szempontból szektának kategorizálható közösségekben is létezik persze társadalmi tőke, ám annak keletkezése a társadalmi hálózat speciális normáitól, értékeitől és szabályaitól függ. A példa illusztrálni kívánta a társadalmi tőke egyik lehetséges árnyoldalát. Elmondható, hogy egy csoport vagy közösség antiszociális viselkedésre felhívó normáival szemben a társadalmi kötelékek közvetítő közeget biztosítanak a társadalmi kontrollnak (Portes 1998). Az is előfordulhat, hogy korlátozhatják az egyéni szabadságot addig a pontig, amíg egyenlőtlenséget teremtenek az egyéni szabadság és a kollektív tett között (Putnam et al. 1993). Példaként hozható fel még a negatív aspektusokra, hogy a társadalmi tőke-nyereség, amit az etnikai alapon szerveződő csoportok jelentenek egymásnak, könnyen átfordulhat negatívumba is. Amikor például egy városba érkező kisvállalkozót felkarol annak etnikai csoportja, s e csoportból kerülnek ki vevői, kuncsaftjai, az a vállalkozói karrier kezdetén nagy segítség, ha azonban huzamosabb idő után sem tudja bővíteni a vállalkozó a vevőkörét, úgy az üzlet bővítésére talán éppen az öt körülvevő etnikai csoport miatt nem lehet képes. Ez az eset is arra figyelmeztet, hogy az erôs kötések túlsúlya a gyenge kötések hiányával párosulva nagy mértékben alááshatja az egyén boldogulási esélyeit (Green-Haines 2016). Más esetekben a társadalmi tőke létrehoz ugyan 
prosperáló kapcsolatokat és csoportkohéziót, de nem feltétlenül vezet a „tőkeképzők" olyan magatartásához, amit társadalmilag kívánatosnak lehetne nevezni. A legkülönbözőbb helyzetekben kialakulhatnak ilyen negatívumok. A bennfentesek és a kívülállók eltérő kezelése óhatatlanul megjelenő tényező, ami ráadásul kitűnően mérhető is tudományos módszerekkel. Diákegyesületek tagjainál figyelték meg például, hogy a vetélytárs egyesületek, illetve azok tagjai kevésbé tehetségesnek, sokszínünek tủnnek fel számukra. De amíg a diákegyesületek tagjai a diplomaosztó után szétszéldnek, addig a társadalmi tőke negatívumainak más aspektusai generációkon át fennmaradhatnak: elég csak az Amerikai Egyesült Államok déli részén a XIX. század végétől az 1960-as évek közepéig fennálló "Jim Crow laws"ra, vagyis a feketék és a fehérek magatartását meghatározó szegregációs mintákra utalni. A két rassz "elkülönítetten egyenlő" tagjainak életvitelét vezérlő normák a társadalmi tőke negatív lenyomatát viselik magukon (Durlauf 1999).

A társadalmi tőke árnyoldala tehát igen komoly potenciális veszélyeket hordoz. Ez a írás az elmélet pozitív oldalára és pozitív dimenzióira fókuszál, hiszen elméleti és gyakorlati értelemben is ezek segíthetik elő az erősebb társadalmi integrációt és a magasabb fokú társadalmi kohéziót. Nem mehetünk el azonban szó nélkül a társadalmi tőke negatív aspektusai mellett: nem demokratikus politikai rendszerekben a vertikális társadalmi tőke alkalmazható a hatalom megszilárdítására, a minél teljesebb közhatalmi kontroll gyakorlására. A társadalmi hálózatokból kirekesztődött emberek pedig például etnikai szegregátumokban, elnyomott élethelyzetben, vagy a fizikai lét peremén, hajléktalanként tengetik mindennapjaikat (Nagy 2004). Ezek a negatív példák is a társadalmi tőke müködésének az eredményei.

\subsection{KÖVETKEZTETÉSEK}

Nincs olyan konszenzusos módon kialakult egységes jelentéstartam és egységes definíció, mely általánosan használható lenne a társadalmi tőke tudományos vizsgálata során. Az elmélet jelentős teoretikusai között sincs konszenzus azzal kapcsolatban, hogy pontosan hogyan is definiálható a társadalmi töke, és pontosan melyek a részei. Pierre Bourdieu a társadalmi tőkét főként kapcsolati tőkeként kezelte vizsgálódásaiban, melyet a csoport birtokol, ám bizonyos esetekben átengedi azt az egyén számára. James S. Coleman a társadalmi tőkét főként kollektív erőforrásként értelmezte, amelyet nem egyének birtokolnak, hanem hálózatok. Robert D. Putnam a társadalmi tőke egyéni és kollektív aspektusait is integrálta elméletébe, 
ám vizsgálódásaiban elsősorban a formális hálózatok világára helyezte a hangsúlyt. Eva Cox elméletében szintén helyet kap az egyéni és kollektív megközelítés; Putnam elméletéhez viszonyítva pedig elmondható, hogy Cox nagy hangsúlyt fektetett az informális hálózatok kapcsolódásainak vizsgálatára (Bourdieu 1979 és 1980; Coleman 1988; 1990; Putnam 1993; Cox 1995; Putnam 1995; 2000).

Az elmélet alapos körbejárásához természetesen meg kellett említenünk a társadalmi tőke negatív tulajdonságait is, illetve az elmélet gyüjtő jellege miatti hátrányokat, melyek az azt alkalmazó kutatókat sújtják. A társadalmi tőkéből elméletben mindenki részesülhet, de azok a személyek, aki nem vesznek részt a társas - társadalmi életben, természetesen el vannak zárva attól. Azok, aki nem rendelkeznek képességekkel, kompetenciákkal és lehetöségekkel ahhoz, hogy bizalomra méltónak mutatkozzanak, nem is nyerhetik el más emberek, illetve szerveződések bizalmát. Saját kutatásaim is alátámasztják azt a szemlézett tudományos szakirodalmakból is kiolvasható véleményt, miszerint akik képtelenek megbízni másokban, a közintézményekben vagy a gazdasági szervezetekben, magukat rekeszthetik ki a kölcsönös előnyökből.

Fontos megjegyezni, hogy a tőketípussal kapcsolatos pozitív állítások és az azonosított dimenziók természetesen kizárólag demokratikus berendezkedésú politikai rendszerekben állják meg a helyüket, illetve felelnek meg a leírtaknak. Alátámasztja ezt Eva Cox $(1995,1998,2007)$ ausztrál kutató elmélete, amely szerint demokratikus környezetben a társadalmi tőke magas szintje bizalmat, kooperációt és általános szolidaritást növelö tényezőként müködik, ám nem demokratikus politikai rendszerekben a versengést erősíti, és kizárhat embereket az alapvető társadalmi folyamatokból, mivel nem teremt kohéziót. Nem demokratikus közegben nem termelödik bizalom és polgári normarendszer sem.

Kutatásom során arra az elgondolásra építettem, hogy a társadalmi tőke a társadalmi hálózatokon, illetve társadalmi részvételen keresztül mindenki számára elérhető. A társadalmi tőke két típusra osztását magam is pártolom, így külön fogok beszélni az egyéni és a közösségi társadalmi tőkéről. Az egyéni társadalmi tőkét a személyes körülmények és a szocializáció által meghatározottnak tekintem. A közösségi társadalmi tőke véleményem szerint az adott hálózat normáin, értékein és lehetőségein alapul, és válik elérhetővé a tagjai számára. Elemzéseimben elsősorban az egyéni társadalmi tőkét fogom vizsgálni, hiszen a másodelemzés kérdőíves adatbázisai föleg azzal kapcsolatban tartalmaznak megfelelő változókészletet. Az egyének elemzéseit aggregált formában, különböző területi szinteken fogom elvégezni. A társadalmi tőke dimenziói közül vizsgáltam az általánosított és 
intézményesített bizalmat. A társadalmi tőke speciális, térségi vizsgálódások esetében releváns megnyilvánulási formái közé sorolom a területi kötődést, amelyet szintén fel kívánok térképezni empirikusan. A bizalom két típusának és a területi kötődésnek a mérésén keresztül tervezek kísérletet tenni a vizsgált térségek társadalmi tőke szintjének mérésére. Egyúttal össze is fogom hasonlítani a bizalom típusainak valamint a területi kötődések mértékének a viszonyát, és megpróbálom megtalálni az elméleti részben olyan egyértelmüen fellelt kapcsolatot e dimenziók között. 


\section{A TERÜLETI IDENTITÁS ÉS KÖTŐDÉS ELMÉLETI ALAPJAI}

A magyar szerzők közül igen sokan írtak az európai identitásról; közülük is kiemelendő Szücs Jenő (1981), aki Európa három történeti régiójáról szóló cikkében beszél egyfajta kezdődő európai identitásról, amelyet főleg kulturális identitásnak tételezett. Ez a megközelítés azonban fontos állomás a későbbi térségi identitáselméletek alakulásában. Mivel az identitáselmélet talán még kutatásom fö áramába tartozó elméleteknél is összetettebb és kutatottabb teória, ez a kitekintés csupán illusztrálni kívánja, hogy a területi alapú kötődésről több megtermékenyítő hatású gondolkodó is értekezett napjainkig. A minket konkrétan érdeklő területi identitáselmélet - föként regionális identitás és kötődés értelemben - azonban új keletü megközelítés.

Ezt az elgondolást támasztják alá Pálné Kovács Ilona (2000, 2001b) területi identitáselméletről írt munkái, melyek szerint a teória nem elcsépelt a társadalomtudományok területén, ahol a témához való kutatási hozzáállás meglehetősen „tág és diffúz keretek között, többfajta megközelítésben lelhető fel.” (Informationen zur Raumentwicklung, idézi: Pálné 2001b. 271. o.) Elmondható továbbá, hogy napjainkra a területi identitás - beleértve a regionális identitást is - részben az Európai Unió regionális politikájának hatására, részben a fejlesztéspolitikai források endogén forrásokra telepítése miatt, illetve az EU integráció elmélyülésének eredményeként növekvő jelentőségü, többdimenziós kutatási témává és jelentős tudományos teóriává vált Európában.

Hasonló véleményt fogalmazott meg Gary Marks (1998), aki szerint a területi identitáselmélet nem tekinthető alaposan feltárt elméletnek, kutatása a cikk keletkezésének idejében még gyerekcipőben járt. A szerző érve az volt, hogy keveset tudunk az egyének területi identitásáról, és még kevésbé tudjuk azt, hogy mi 
okozhatja az abban bekövetkező változásokat, melyeket az Eurobarometer ${ }^{3}$ kérdőív adatai jeleznek. Az elmélet az eltelt tíz évben fontos kutatási területté vált, sok kutató reflektált rá cikkeiben és könyvfejezeteiben. A területi identitás dimenziói hasonlóan nagyszámúak, mint a társadalmi tóke elmélet esetében felsorolható tartalmak, és az eltérő megközelítések e teória esetében is jellemzőek. A különböző területi szintekkel, illetve szintekhez való identifikálódás sokdimenziós kérdés, melyből föképp a kérdés társadalmi dimenziója érdekel bennünket. Nem feledkezünk meg a lokális identitásról sem, melynek kiterjesztődése tapasztalható a területiség dimenziójának kiteljesedésével.

A területi identitás nagyon fontos társadalmi alapokon nyugszik, legfontosabb összetevőjének egyfajta összetartozás érzés tekinthető, amelyet a területileg egy helyen élő emberek egymás és az adott terület iránt éreznek, és kognitív módon az adott térséghez kötnek. Fontos elemei még az emberek egymásba és a térségi intézményekbe vetett bizalma, a társas kapcsolatok térségi szinten jól müködő rendszere és az azonnali viszonzás reménye nélküli önzetlen segítség az adott hálózaton belül.

Az identitásfogalom társadalmi vetületével kapcsolatos vizsgálódások szempontjából fontos megemlíteni az identitás egyéni és kollektív jellegét. Thoits és Virshup cikke (1997) boncolgatja, hogy hova is tartozik inkább a társadalmi identitás: az egyéni vagy a kollektív identitás elemei közé. Az egyéni identitások általában az egyén személyes azonosulási faktoraira utalnak, és a „ki vagyok én?” kérdésre adnak választ. A társadalmi identitások az egyén társadalomban elfoglalt helyével kapcsolatban hordoznak információt, és a „kik vagyunk mi?” kérdésre szolgálnak felelettel. A területi identitásokat megismert tulajdonságaik alapján a társadalmi alapokon nyugvó kollektív identitásokhoz lehet besorolni. A szerzők megjegyzik, hogy a társadalmi identitás modellek általában csoportokon belüli és csoportközi folyamatokon, kapcsolódásokon alapulnak, nem pedig az emberek egyéni identitásán.

Anssi Paasi elgondolása szerint a térbeli egységeket és az azok által hordozott jelentéstartalmakat az emberi cselekvés hozza létre. Ezek az egységek létezhetnek valamennyi ideig, ám végül eltünnek - vagy kisebb darabokra szakadnak, vagy pedig beolvadnak egy nagyobb térbeli társadalmi egységbe. Jelenlegi Európafelfogásunk intézményesített gyakorlatokon alapul, valamint diskurzusokon,

3 Az EURUBAROMETER az Európai Bizottság által évente többször, különböző témákban elvégeztetett, 1973 óta futó kutatássorozat. A szerző a nyolcvanas évek végén és a kilencvenes évek elején felvett adatokra alapozza állítását. 
melyek a politika, a gazdaság, a kormányzás, a kultúra és a média, valamint az oktatás területein zajlanak. Mindezen területeken átméretezési folyamat megy végbe. A probléma alapja az, hogy nem csupán egy Európa létezik, hanem vannak versenyzö, átfedő Európák - intézményesített gyakorlatok és diskurzusok halmazai -, melyeket a hatalom és ideológia egy bizonyos formája tart össze (Paasi 2005). A regionális identitás persze nem európai kontextusban is értelmezhető, sőt értelmezendő, annak kapcsolata a globalizáció jelenségével feltehetően még erősebb is, mint az európaizáció folyamatával.

Bugovics Zoltán (2007) értelmezését felhasználva arra juthatunk, hogy a területi identitás egy komplex rendszer része, melyben a természeti környezet és a társadalom totális kölcsönhatása meghatározó tényező. A területi identitást a természeti dimenzió mellett befolyásolja a gazdasági és infrastrukturális környezet dimenziója is. Emellett jelentős hatással vannak rá a társadalmi kategórián belüli egyes elemek is, melyek értelmezhetőek szociológiai változók formájában. A Bugovics által alkalmazott területi identitás alkotóelemek közül ezen írás szempontjából kiemelt fontosságúnak tekinthető a területi kötődés, a társadalmi aspektus, a részvétel és a bizalom, valamint az elégedettség és elégedetlenség dimenziója.

Bőhm Antal (2000) értelmezését felhasználva azt állíthatjuk, hogy az identitás szorosan összekapcsolódik a társadalmi valóság értékkategóriáival. Említést tesz a társadalmi rendszer megváltozásával létrejövő identitásváltozásokról, azaz a totális rendszerből kilépő társadalom identitás átalakulásáról. Elmondható, hogy a területi identitás is erős összefüggésbe állítható a demokratikus rendszerrel, az identifikálódás kategóriái ebben a környezetben tudtak kiteljesedni és a világban zajló reálfolyamatokra reagálni. Egyik ilyen reálfolyamatnak az identitás területi szintjeinek átalakulása tekinthető. Bőhm megállapította, hogy a „globalizációval egy időben az állampolgárok a lokális (regionális) szinten találták meg mindennapi életmódjuk régi-új kereteit" (Bőhm 2000, 114 o.).

A területi identitás átalakulásával kapcsolatban fontos információkat közöl Moreno (1999) az „új kozmopolita lokalizmus” jelenségéről írt cikkében. Véleménye szerint a bottom-up (alulról-felfelé) zajló transznacionális fordulat és a hatalom top-down (felülről-lefelé) jellegű devolúciója elvezetett az európai kozmopolita lokalizmus elterjedéséhez. Az európai társadalmakba történő integráció, az azokkal való identifikálódás előfeltételévé vált egy civil értékrendszer és toleráns beállítódás adaptálása, melyek nagyban megkönnyítik a beilleszkedést. Helyi vagy középszintü területi egységek esetében az integráció lehetséges 
szinte bármilyen társadalmi körülmények közé. Ez a folyamat a helyi közösség megerősödését eredményezi a nemzetközi részvétel megerősítésével egy időben, és az új Európát a helyi identitások megerősödése, valamint a globális szintű cselekvések nemzeti szintek feletti átnyúlása jellemzi.

Michael Bruter könyvében (2005) a területi identitás vizsgálatát az európai identitás vizsgálatán keresztül közelíti meg. A szerző a politikai identitások vizsgálatát végzi el, melynek szerinte részei a különböző területi szintekhez történő identifikálódási folyamatok. Azt állítja, hogy a szubszidiaritás politikai szándéka az identifikálódás folyamataira is kihatott, és az emberek többrétegü identitásstruktúrával rendelkeznek a különböző területi szintek irányában. Az adott területi szintekkel való identifikálódás bizonyos esetekben - amennyiben a területi szintek kormányzási szempontból is releváns szintek - politikai identifikálódásnak is tekinthető. Így van ez például az európai, nemzeti és helyi szintek esetében szinte minden európai országban, illetve a szubszidiaritás elvének érvényesülésével sok helyen a regionális szinttel való politikai identifikálódás is erősödik. Az identifikálódás alapvetően társadalmi folyamata tehát közvetlen hatással van a politikai szféra folyamataira, illetve közvetlenül azokból táplálkozik.

Jensen és Richardson (2004) fontos elméletet dolgozott ki az európai kohéziós politikával kapcsolatban. Véleményük szerint - melyet magam is osztok - a kohéziós politika alapvetően formálja át a korábban létező területi identitásokat. A változást előidéző területi politika célja egységes recepciót adni az európaiság gondolatának a tagállamok lakossága körében. Ennek fényében elmondható, hogy az európai integráció különböző politikai vetületei új mentális kereteket szolgáltattak kötődéseink átértelmezéséhez. A folyamat által átformált, a területi identitás fogalmához hozzákapcsolódott szókészlet önmagában is erősíti az Európai Unió állampolgáraiban az összetartozás gondolatát. A területpolitikai intézkedések a kohézió fogalmát egyértelmủen hozzákötik a területi identitás fogalmához.

Munkámban nem magát a területi identitást használom fel elméleti és módszertani vizsgálódásaim alapjául, hanem a területi kötődést. A területi kötődés a területi identitás egyik legfontosabb eleme, mely azonban talán könnyebben operacionalizálható a társadalomtudományi vizsgálódás szempontjainak megfelelően (Lásd: 4. tábla, 70. oldal). Ennek okaként az identitáskutatás szerteágazó tudományos megközelítéseit jelölhetjük meg, melynek feltárása nem valósítható meg hitelesen e munka terjedelmi és tematikus keretein belül. 


\subsection{A TERÜLETI KÖTŐDÉS VIZSGÁLATÁNAK JELENTŐSÉGE}

A területi identitás és egyik fő dimenziója, a területi kötődés vizsgálata ma kiemelkedően fontos az Európai Unió tagállamaiban. Ennek egyik oka az európai identitás, ezen belül az Európához való kötődés kiemelt jelentősége. Az Európai Unió egy nemzetek feletti, közvetlen politikai legitimációval csupán a kevés hatalommal bíró parlamentjén keresztül rendelkező szervezet. A jövőjét igen erősen determinálja polgárainak gondolkodása róla, illetve identifikációja vele. Az egységes európai eszme maga is azon a gondolaton alapul, hogy a polgárok képesek lesznek kötődni Európához. Érdemes tehát belemenni az Európa fogalom és az európai integrációhoz tartozó fogalmak jelentéstartalmainak vizsgálatába, hogy azonosítani lehessen a kötődés különböző dimenzióit.

Európa napjainkban nem értelmezhető csupán egydimenziós formában. Ezzel kapcsolatban Waever (1997) tézisét érdemes áttekinteni:

„Európa fogalma nem egy magelmélet, illetve nem egy olyan csíra, amelyet megtalálunk a történelemben, és a fejlödését nyomon tudjuk követni a különbözö korokban. Inkább számos fogalomtöredék története, amelyek Európa ideájához különbözö pontokon kapcsolódnak, és újra és újra megfogalmazódnak a különbözö idöszakokban. Öt fö eleme volt az Európáról szóló domináns diskurzusoknak: Európa, mint földrajzi fogalom; a szabadság fogalma; Európa, mint a kereszténység; a hatalom egyensúlya és az európai civilizáció." (Wcever 1997, 285 o.)

A fent említett Európa-dimenziók mellett létezik egy további diskurzus: a régiók Európája dimenzió és diskurzus. Az Európai Unió kortárs térképén nem csupán nemzetállamok szerepelnek, hanem kisebb egységek százai is; határokon átnyúló transzrégiók, illetve nemzetállami határokon belüli régiók színes palettája. Európa kisebb területi egységekre osztódását nevezik Európa „svájcizálódásának” is („Swissification of Europe”) (Buzan-Wæver-de Wilde 1998).

Európa fogalomtöredékek és diskurzusok összességeként értelmezhető a leghelyesebben e mủ szerzőjének véleménye szerint is. A területi kötődés szempontjából kifejezetten érdemes-e tág értelmezést megtartani, hiszen aligha láthatunk bele az emberek fejébe, és tudjuk pontosan lehatárolni, hogy az Európa-fogalom pontosan melyik dimenziójához is ragaszkodnak, mely dimenziót, illetve diskurzust tartják 
jelentősebbnek a többinél. A napjainkban folyó, kötődéseket és identitást vizsgáló kutatások többségének egyik fö célja pontosan az európai polgárok kötődési dimenzióinak feltárása.

Jelen mü fontos feltevése, hogy a magyar emberek gondolkodásában a régiók, mint közigazgatási és földrajzi egységek Európához és az Európai Unióhoz kötődnek, hiszen létrehozásukat hazánkban európai uniós kívánalomként kommunikálták (Pálné Kovács 2001b, 180 o.). E fejezet fontos állítása továbbá, hogy az Európához való kötődés manifesztálódhat a régióhoz való kötődésen keresztül is. A regionalizáció folyamatának megindítása és az Európai Unió „elmélyítésének” az ötlete abból a felismerésből fakadt, hogy az emberek mindennapi életükben nem érezték az Európai Unió létezésének pozitív hatásait. Az európai döntéshozók közel akarták hozni Európát a polgáraihoz. Végül ezt a lépést azonban a régiók mozgalma volt képes politikai eszközökkel elérni, a német Landok vezető szerepével. A mozgalom elérte a szubszidiaritás elvének régiókra való kiterjesztését és alkalmazását. A régiók, melyek néhány országban csupán gazdaságfejlesztési és statisztikai egységek voltak korábban, közigazgatási és esetleg kormányzati egységekké is válhattak az EU tagállamaiban (Pálné Kovács 2008). A sikerrel párhuzamosan a régiók a kohéziós országokban a fejlesztési források elosztásánál is fontos szerephez jutottak. (Pálné Kovács 2001a, 2001b, 2002). Napjainkra a helyzet azonban megváltozott, világosan látható, hogy a magyar régiók a kormányzati politika kizárólagos kiszolgálóivá váltak, és Európai szinten is válságban van a „Régiók Európája” elgondolás (Pálné 2008; Elias 2008).

A fenti állításokat alátámasztja a többszintű kormányzás Arató Krisztina által idézett, Thomas Risse-Kappen és több más szerző (Jefferey 2000; Hooghes - Marks 2006; és mások) által megfogalmazott elképzelése, mely a többszintü kormányzást három szinten, az államok szintjén, a szupranacionális és a szubnacionális szinten képzeli el. A szubnacionális szint aktorainak az önkormányzatokat tekinti, a többszintủ kormányzásba való belépésük idejét a kilencvenes évek elejére teszi. Példa erre a Régiók Bizottsága, amelyet a maastrichti szerződés hozott létre, és kétszáz euro-régiónak, illetve nagyvárosi önkormányzatnak ad jogot döntési tervezetek véleményezésére. Ezen formális csatorna mellett az önkormányzatok informális csatornákon keresztül is érvényesíteni próbálják érdekeiket. A tagállamok a szupranacionális szintre feladnak, a szubnacionális szintre pedig leadnak döntési kompetenciákat (T. Risse-Kappen, idézi: Arató 2000, 63-65. o.). Az Európai Unió intézményi struktúrájában a régiók helyzete azonban sokat változott az elmúlt években. Visszaszorulni látszik a regionális szint szerepe a politikai döntések 
befolyásolásában a közösségen belül, és tagállamok többségén a régiók szintén veszítenek politikai súlyukból. A kialakult helyzet alapján érthető, hogy kutatók a „régiók Európája” koncepció végéről írnak (Pálné 2008; Pálné 2009; Elias 2008).

Az EU csatlakozást megelőző és az azt követő években Magyarországon tapasztalható volt egyfajta euro-optimizmus. Az ebből következő nagyfokú euroszimpátia feltehetően elmosta az elválasztó falat az Európa-fogalom, az Európai Unió és valamennyire a régió fogalmak jelentései között. A kétezres évek vége felé azonban már lecsengeni látszik a kezdeti optimizmus, egyúttal szembesültünk a „régiók Európája” koncepció hanyatlásával és az európai régiók politikai térvesztésével is. Az optimizmus csökkenése az évek múlásával természetes velejárója az Európai Uniós csatlakozásnak, ám az európai régiók térvesztése olyan új körülmény, melynek hatása nem elöre becsülhető formában és mértékben fejti ki illetve fogja kifejteni hatását a magyar régiók helyzetére.

Magyarország térszerkezetét vizsgálva, két csoport kínálkozik elemzési lehetőségként: az új térszerkezeti kategóriákat tartalmazó csoport, melynek elemei a kistérség, a régió és szupranacionális egységként maga az Európai Unió, illetve a régi térszerkezeti elemeket tömörítő csoport, melynek elemei a település, a megye és a nemzeti szint. A 2. ábrán az Eurobarometer kérdőívben vizsgált területi szintek kapcsolódásait jelenítettük meg.

\section{2. ábra - Területi szintek és kapcsolódásaik}

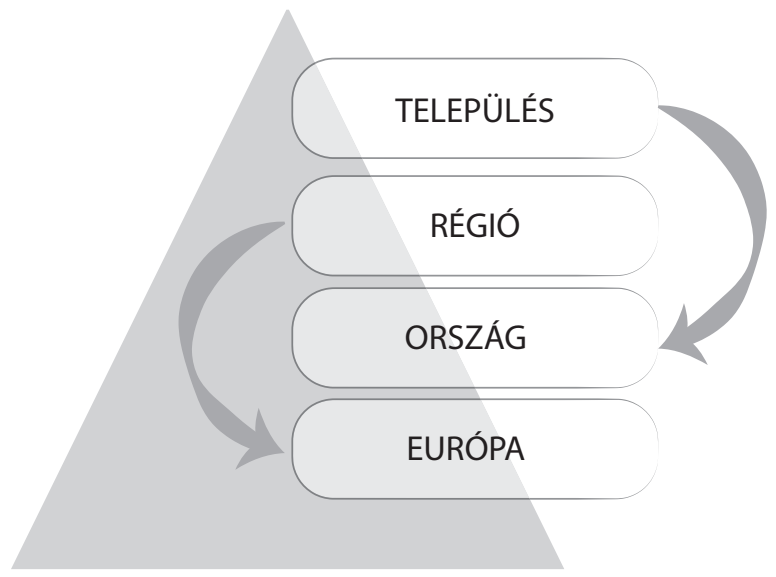

Forrás: Saját szerkesztés 


\subsection{A TERÜLETI IDENTITÁSRÓL ÉS KÖTŐDÉSRŐL ÁLTALÁBAN}

A területi identitás és kötődés egymással relációba állításának illetve elválasztásának céljából Gary Marks (1998) elgondolását veszem alapul. Marks-al egyetértve azt mondom, hogy a területi identitás például az Európai Unió esetében nehezen értelmezhető, mivel annak létrejöttét az Európa - gondolat jelentős személyiségei is csupán egy hosszabb időszak eltelte után feltételezték. Marks szerint az EU polgárai identifikálódni napjainkban elsősorban saját nemzetállamaikkal tudnak, azoknak a helyét identifikációs faktorként nem vette még át az európai szint. A nemzeti identitás elemeiről számos mü áll rendelkezésre, melyek több faktort állapítanak meg annak elemeiként illetve feltételeként. Marks-szal egyetértek abban, hogy nem szerencsés, sőt feltehetően nem is érvényes európai identitásról beszélni, egyfelől a fent említett korlátozás, másfelől az identitás koncepció gazdag fogalmi telítettsége (van Houtum - Lagendijk 2001; Bugovics 2007) miatt. Lehetséges azonban kötődésről beszélni az Európai szint esetében, mely az adott szinttel kapcsolatos beállítódásokat képes hitelesen megjeleníteni, és nem viseli magán az identitás metaelméleti szintű komplexitását. A területi kötődés használata a területi identitás empirikus indikátoraként ilyen formában is igazolható, ám további elméleti áttekintésre szorul.

A területi kötődés szempontjából releváns kutatást végzett Cuba és Hummon (1993) Észak-Amerikában, amikor megvizsgálta, hogy mi köti az embereket különböző helyekhez. A vizsgálat érdekességeként említhető meg, hogy a hely mérete, melyhez az ott lakók kötődnek, illetve a helyi közösség igen fontos szempontokként merültek fel a szerzők gondolkodásában. Igyekeztek olyan kategóriákat vizsgálni, amelyek leképezték az egyének életterét. A terepmunkát Massachussets államban, Cape Cod térségében végezték 437, a térségbe beköltözött migráns körében. A kötődés szempontjából vizsgált területi szintek a közvetlen lakóhely, a helyi közösség és a régió voltak. A régió ebben az esetben föként környezeti és kulturális értelemben használt fogalom, közigazgatási relevanciával.

A migránsok 43 százaléka kötődött egyaránt közvetlen lakóhelyéhez, a helyi közösséghez és a régióhoz. A kötődés egységenként vizsgálva: (1) közvetlen lakóhely: 71 százalék, (2) helyi közösség: 67 százalék és (3) régió: 65 százalék. A levont következtetés kimondja, hogy a lakóhely szeretete és a helyi közösségbe való beintegrálódás sikeressége határozza meg a nagyobb területi egységhez való kötődést. 
A kutatás eredményei megmutatták továbbá, hogy a válaszadók saját demográfiai jellemzői mellett a kötődés kialakulásának komoly meghatározó tényezője, hogy milyen környezetben élnek az ott lakók, milyen a helyi közösség, és a helyi közösségnek milyenek a kapcsolatai más hasonló közösségekkel. Fontos megállapítás, hogy azokra a kérdésekre, hogy milyen helyekhez kötődnek az emberek, illetve hol érzik otthon magukat, csupán több, egymástól látszólag független dimenzió elemzésének segítségével adható válasz (Cuba- Hummon 1993).

A területi kötődést a szemlézett szakirodalom alapján (Bőhm 2000; Bugovics 2007; Marks 1998; Pálné Kovács 2001b) a területi identitás egy elemeként kategorizálhatjuk be. Többféle tipológiával találkozhattunk, többféle identitáskoncepcióval, melyek között váltakozó mértékben oszlott meg a területi kötődés fontosságának megítélése. Ezen értekezésben mégis a területi kötődést jelöltük meg a vizsgálódás egyik fő tárgyaként. Mi teszi a kötődés ezen formáját érdekessé, kutathatóvá és kutatandóvá? Egyrészt az a tény, hogy az identitás más elemei (például a kultúra, a nyelv, a nemzeti vagy etnikai hovatartozás, a szokások, ragaszkodások, kapcsolatok, helyek) nehezen konceptualizálhatóak egy elméleti keretbe és egy diszciplína határain belülre. Az említett identitás elemek mérésre operacionalizálása még komolyabb kihívás elé állíthatja a vizsgálódót.

A területi kötődés vizsgálatával kapcsolatban jó minőségü és a longitudinális összehasonlítás lehetőségét biztosító adatbázisok állnak rendelkezésre, például az Eurobarometer kérdőív különböző hullámai (EUROBAROMETER 62.0, 63.4, $65.2,67.1,67.2)$.

A területi kötődés vizsgálata során szembekerültünk azzal a kézenfekvő módszertani kérdéssel, miszerint a polgároknak nincsenek kizárólagos területi kötődései. A globalizáció korában élő, posztmodern ember, földrajzi egységekhez való fizikai kötődése már túlzottan elavult gondolatnak tetszik. Abban a világban, amikor az emberek virtuális világokhoz, terekhez és szimbólumokhoz kötődnek, a valós területi kötődések világa kevésbé tünhet érdekesnek (Némedi 2008, 43-46 o.). Ez a kötődési rendszer is tartalmaz azonban kihívásokat. Mivel az általunk vizsgált területi egységek különböző szinteken léteznek a területi struktúrában, ezért elmondható, hogy az egyes egységek egymáson belül helyezkednek el. Ezért kiemelten fontos megvizsgálni a többszörös kötődéseket. A Gary Marks (1998) munkája által inspirált 3. ábra alapján a legtöbb polgár az „A”, azaz többszörösen kötődő kategóriába tartozik, amennyiben kötődéseiket empirikusan vizsgáljuk. 


\section{3. ábra-A kötödés típusai}

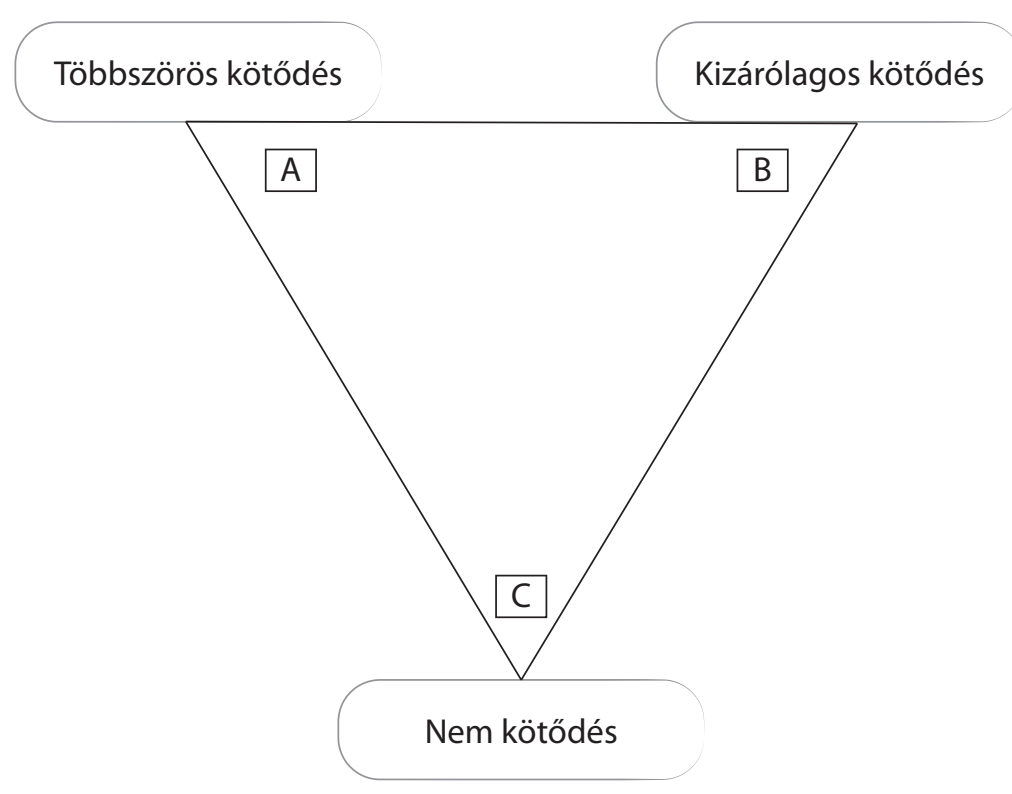

Forrás: Marks 1998

\subsection{EURÓPAI IDENTITÁS - KÖTŐDÉS EURÓPÁHOZ}

Az Európához való kötődés az unió alapító atyáinak szándéka szerint gátat vethetne a féktelen nacionalizmusnak Európa országaiban, amely rengeteg problémához és konfliktushoz vezetett a múltban és vezethet a jövőben. Az alapító atyák hittek abban, hogy a nemzet iránt érzett hazaszeretet érzése meg fog férni az Európához való kötődés érzésével az emberek gondolkodásában. Az európai identitás alapjának az európai integrációt tartották. Azonban a kezdeti európai intézmények az európai emberek nélkül épültek fel, csupán szük eliteket bevonva munkájukba. Az európai integráció veszélybe került: sok esetben átpolitizálódott, nemzetállami érdekeket sértővé vált. Megnyugtató folytatása ezért csupán akkor lehetséges, ha valamiféle tényleges kötődés alakul ki az európai polgárokban Európa felé (Marks 1998).

Fontos további megállapítás Gary Marks (1998) részéről, hogy a képviseleten alapuló többségi elv csupán akkor müködhet, ha a rendszer megalkotásakor létezett 
valamiféle kollektív identitás. Mivel az Európai Unió esetében ilyenről aligha beszélhetünk, valamilyen más közös alapra van szükség, hogy az európaizáció vesztesei és nyertesei egyaránt ugyanahhoz az Európa-ideához kötődjenek. Ugyanezen megállapítás igaz azon társadalmi rétegek esetében is, amelyek a javak újraelosztásából nem egyformán részesülnek napjainkban, vagy részesültek a múltban. A fentebb említett társadalmi csoportok értelemszerúen nem egyformán lesznek elkötelezettek az „Európa-idea” iránt. Az, hogy az európaiak identifikálódnak-e a nemzetállami szintjük felett létező közösséggel, kulcskérdés az Európai Unió szempontjából. A kétsebességes Európa koncepciója éppen azért került kidolgozásra, hogy az esetleg eltérő elköteleződési szintekkel rendelkező országok eltérő sebességgel tudják megtenni az integráció lépéseit.

A közösség vezetői éppen ezért figyelemmel kísérték és kísérik a polgárok Európához való viszonyát. Folyamatosan kapnak és kaptak visszaigazolást arról, hogy a kötődés Európához, mint kollektív eszméhez nem kizárólagos. Kötődési rendszerek alakultak ki, a hüség a nemzetállami szintről nem csúszott „fel” az Európai Unió szintjére, azonban az Európához való kötődés jelentősége nagymértékben nőtt Nyugat-Európában a kilencvenes évek elejére (Wallace 1990). Elmondható továbbá, hogy a közösség „mélyítésével” és a „többszintű kormányzás” megjelenésével a nemzetek alatti szinthez való kötődés is egyre fontosabb tényezővé vált és válik.

Az európai kötődésnek több lehetséges eleme is van. Ha Európáról beszélünk, előfordulhat, hogy elsőnek az Európai Unió és intézkedései jutnak eszünkbe, föként, ha az „Eurobarometer” kérdőív lekérdezése közben kerül szóba. A 3. tábla mutatja be, hogy különböző szociológiai interjú kontextusban hogyan értelmezhetjük a különböző kategóriákat. Természetesen a kategóriák mögött megbúvó kognitív jelentéstartalmak értelmezésére a kutató csupán kísérletet tehet.

\section{3. tábla - A kötődést vizsgáló kérdés kategóriáinak jelentése}

\begin{tabular}{|l|l|l|l|l|l|}
\hline $\begin{array}{c}\text { Eurobarometer } \\
\text { interjú }\end{array}$ & \multicolumn{1}{|c|}{$\begin{array}{c}\text { Jelentés (adott } \\
\text { kontextusban) }\end{array}$} & $\begin{array}{c}\text { Más szocioló- } \\
\text { giai interjú }\end{array}$ & & $\begin{array}{c}\text { Jelentés } \\
\text { (adott kontextusban) }\end{array}$ \\
\hline Település & $=$ & Település & Település & $=$ & Település \\
\hline Régió & $=$ & NUTS 2 régió & Régió & $=$ & Tág régióértelmezés \\
\hline Ország & $=$ & Magyarország & Ország & $=$ & Magyarország \\
\hline Európa & $=$ & Európai Unió & Európa & $=$ & Tág Európa-értelmezés \\
\hline
\end{tabular}

Forrás: Saját szerkesztés Haesly 1999 alapján 
Anssi Paasi szerint (2005) az EU lépésröl lépésre monopolizálni fogja Európa gondolatát, attól függetlenül, hogy egy központosított föderális államról beszélhetünk majd vagy egy kevésbé hierarchikus újközépkori modellröl.

Eltekintve tehát a speciális Eurobarometer interjúszituációtól, illetve bármilyen más helyzettől, ami egyértelművé teszi a fogalmak jelentését, ha „Európáról” beszélünk, a fentiek mellett érthetjük alatta magát az integrációs folyamatot is. Azt a folyamatot, mely az Európai Uniónál talán egy szélesebb társadalmi támogatással rendelkező dolog. Érthetünk továbbá „Európa” alatt egy területi egységet, mely földrajzilag lehatárolható, vagy egy eszményt, amely felé az azt támogató ember ezer különféle szállal képes kötődni. Ezen értelmezési lehetőségek fényében tehát elmondható, hogy nemcsak a kötődés szintje, de a típusa is igen lényeges információkat hordoz a kutatók számára. Ha információkat nyerünk az Európához való kötódéssekkel kapcsolatban, képesek leszünk jobban megérteni azt a politikai környezetet, amelyben azok képződtek (Haesly 1999).

\subsection{REGIONÁLIS IDENTITÁS - KÖTŐDÉS A RÉGIÓHOZ}

„A regionális identitás azon folyamatok interpretációjaként is értelmezhetö, amelyek keretében egy régió intézményesülése lezajlik. E folyamatok eredményeként kerülnek kialakitásra a terület határai, szimbólumai és intézményei." (Paasi 2003, 478 o.)

Az, hogy beszélhetünk-e regionális identitásról, jelentős mértékben függ az alkalmazott régiófogalomtól. A különböző diszciplínák divatos, illetve széles körben alkalmazott régiófogalmai sok esetben eltérőek lehetnek. Vannak olyan régiófogalmak, amelyek tartalmukból fakadóan egy bizonyos diszciplínához köthetőek, illetve általánosságban elmondható, hogy egyes régiófogalmak bizonyos tudományágakhoz közelebb vannak, más tudományágaktól pedig távolabb. Tovább nehezíti a fogalomhasználat egységesítést, hogy a régiók, mint területi egységek teljesen más értelmezéseket támasztanak napjainkban, mint korábban.

Ezen gyökeres változás alapja, hogy megváltozott a „hely” fogalom értelmezése. A „hely” elgondolás napjainkban értelmezhető globális, nemzeti, regionális és lokális szinten egyaránt. A „hely” fogalom mellett a „határ” fogalom is nagymértékben megváltozott a globalizáció térnyerésével és a technikai innovációk rohamos terjedésével. Anssi Paasi (2000, 2002a) Doreen Massey-t idézi, amikor arra 
figyelmeztet minket, hogy az identitások, amelyek helyekhez kötődnek, sohasem „tiszta” identitások ${ }^{4}$ (Massey 2005). A nemzetállamok világából a nemzetek feletti államok világába való átlépéshez több átjárási lehetőségre lesz szükség politikai, kulturális és szimbolikus értelemben egyaránt. Ezen felismerések fényében nagy valószínűséggel állítható, hogy a „hely” fogalmi jelentésének megváltozásával megváltozott a helyi identitás és területi identitás fogalmak jelentése és értelmezhetősége is. Emellett a regionális világok komplexitása a globalizáció jelenségeinek folyamatos és párhuzamos előre haladásával folyamatosan növekszik. Különböző társadalmi gyakorlatok és diskurzusok rejtik el a jelentéstartalmakat és a kötődések eredeteit, azok forrásait (Paasi 2000, 2002a, 2002b).

„A regionális identitás narrativák több különféle tényezön is alapulhatnak. Ezek az elemek lehetnek természeti elemek, tájelemek, épitett környezet, kultúra és etnicitás, nyelvjárások, gazdasági sikerek vagy válságok, centrum-periféria relációk, marginalizáció, emberekkel és közösséggel vagy közösségekkel kapcsolatos sztereotípiákra épülő képek, a „mi” és az „ők” koncepciója, tényleges vagy kitalált történelmek, utópiák és eltérö elgondolások és érvek az emberek identifikációjával kapcsolatban. A felsorolt elemeket kontextuálisan használják fel gyakorlatok, rituálék és diskurzusok annak érdekében, hogy többé-kevésbé zárt elképzelt identitásokat konstruáljanak." (Paasi 2003, 477 o.)

A regionális társadalmi kohézió erősítése fontos feladatként jelent meg a regionalizáció folyamatai kapcsán. Az Európához való kötődés megerősítése a középszint társadalmi kohéziójának növelésén keresztül vált lehetségessé. Pálné Kovács Ilona (2001b) megjegyzi, hogy ha egy terület nem rendelkezik megfelelő politikai érdekérvényesítő képességgel, az romboló hatással lehet az ott létező területi identitásra nézve. A szerző munkájában összeköti a politikai régiók létrehozásának szándékát a területi-regionális identitás megteremtésének, illetve növelésének a szükségességével, mint nélkülözhetetlen előfeltétellel. A hagyományos identitás-dimenziók, így a történelmi-kulturális tradíciók, és az intézményi keretek hiánya azonban a régiók esetében sokszor megnehezítheti ezt a feladatot.

\footnotetext{
4 Lásd a kötődés típusokat bemutató 3. ábrát.
} 
A regionális identitás szerepe a régiók életében többrétű: egyfelől elvándorlást megállító és gazdaságélénkítő hatása lehet, hozzájárulhat a térségben élő emberek komfortérzetének növekedéséhez. Másfelől elmondható, hogy alapvető feltétele a régióban létező kapcsolathálózatok jó müködésének és az általános bizalom megteremtésének. Az identitás dinamikus tényezőként értelmezendő, ahogy a helyi társadalomban növelhető a szintje, úgy rombolható is (Pálné Kovács 2001b).

Sok országban az európai regionalizmus adaptációja nem vezetett új területi egységek megalkotásához. Nem így volt ez azonban Magyarországon. Faragó László (2005) szerint a nemzetállamok a szupranacionális és regionális szintek megjelenése miatti potenciális veszteségeiket az utóbbi szint életébe történő beavatkozással akarják csökkenteni. A nemzetállamok igyekeznek minél kiterjedtebb szerepet vállalni a regionalizációban, és ezáltal minél több irányítási szerepkört megtartani a szint fölött. A kohéziós országokban az Európai Unió a támogatások nyújtását a regionális rendszer kialakításának a feltételéhez köti, ami azt eredményezi, hogy az itt létrejövő régiók a nemzeti struktúrák termékei, csupán bizonyos funkciók ellátására szerveződnek. A már kialakult tervezési-fejlesztési (NUTS 2) régiók érdeke a minél több külső forrás megszerzése a régiók közötti versenyben, ezért ezek a térségek elvileg egymással versengő pozícióba kerültek (Faragó 2005).

A regionális identitás mérni kívánt eleme, a regionális kötődés mérésével kapcsolatban tartjuk az álláspontot, miszerint a régiókhoz való kötődést az Eurobaromter kérdőíves interjúhelyzetben veti fel a kérdezőbiztos, egyértelmü, hogy az az EU-s területi rendszer NUTS 2-es régiójára gondolni (Lásd: 3. tábla 63. oldal).

\subsection{KÖTŐDÉS A KONVENCIONÁLIS TERÜLETI EGYSÉGEKHEZ}

A vizsgálat során az új típusú, az Európai Unióhoz és régióhoz, mint területi és közigazgatási egységekhez való kötódés vizsgálata mellett megvizsgáljuk a hagyományos kötődéseket is. Bugovics Zoltán (2007) szerint a település, mint lokalitás a területi identitás egyik legmeghatározóbb tényezője. Ezen állítását a szerző széleskörű szakirodalmi szemlére alapozza, és megállapítja, hogy ez az állítás föként a kilencvenes évek közepétől nyert alátámasztást empirikus kutatásokban. 
Megjegyzi, hogy a településeken belül az egyes településrészek nem hordoznak speciális identitás-mintákat, egy-két markáns kivételtől eltekintve, ezért a településeket nem feltétlen kell kisebb egységekre osztani a vizsgálat szempontjából. Persze felmerülhetnek helyzetek, amikor településrészeknek is lehet lokális identitása, példák lehetnek erre a közigazgatásilag egyesített települések illetve a nagyvárosi peremkerületek.

A megyéröl, mint konvencionális területi egységröl azt írja Bugovics, hogy az sem nem elég kicsi, hogy könnyen bejárható legyen, sem nem elég nagy, hogy megfeleljen a makroszintű tervezés léptékeinek. Idézi Bódi Ferencet, aki kutatásai alapján megállapította, hogy a régió felel meg leginkább a területi társadalmi fejlódés középterének, és nem a megye. Ugyanakkor nem szabad megfeledkezni arról, hogy a területiség mellett a megyerendszerhez gazdasági és kulturális értékeket is kapcsol (Bugovics 2007, 143. o.).

Pálné Kovács Ilona (1999) a jogi szabályozás tárgyalásakor említést tesz arról, hogy a kormányzás szempontjából a megyei szintet ún. szubszidiárius szintként kezeli a jogalkotó. A megyének azokra az esetekre van jogköre, amikor a települések nem tudnak, vagy nem akarnak helytállni. A megyei önkormányzatok feltehetően az említett ok miatt nem váltak az önkormányzati rendszer fontos szereplőivé; a közvetlenül választott megyei önkormányzatok nem egyenlő szereplők a magyar önkormányzati rendszerben. A megyei jogú városok speciális státusza is gyengítette a megyei önkormányzatokat szerepük kiterjesztésében, mint a kezdetektől homályos feladat- és eszközrendszerük.

Pálné Kovács (1999) szerint kijelenthető azonban, hogy fontos érvek szólnak a tisztázott szerepü, erősebb megyei szint megteremtése mellett, mert például a töredezett magyar településszerkezetet nem lehet alsó-középszint nélkül 6-7 régióra helyezni. Az identitás-építés szempontjából kérdésként vetődik fel, hogy vajon a megyei identitás romjaira fog-e épülni a majdani regionális identitás hazánkban.

Kákai László (2000) cikkében a dél-dunántúli régió megyéinek megyei identitásait vizsgálta 1994 és 1998 között. A megyék helyzetével kapcsolatban megjegyezte, hogy a megyei közgyülések nem voltak képesek ellátni a rájuk rótt integratív szerepet, és nem tudtak hatékonyan részt venni a megyei identitás felépítésében. A szerző megállapítása szerint akkor az intézmények a megyei identitás felépítésének a kezdetén tartottak. Legfontosabb ellenfeleik ebben a folyamatban pedig pont a konvencionális területi struktúra legfontosabb elemei, a városok, föként a nagyvárosok voltak. 
A megyéhez való kötődés azonban nem vizsgálható a többi területi szint kötődéseivel együtt, csupán egy, a szegediek kötődéseiről szóló esettanulmányban került be a kötetbe. Ennek oka, hogy az Eurobarometer kérdőívekben a Magyarország csatlakozás után felvett hullámokban 2007 végéig egyetlen esetben sem kérdezik a lakosság kötődését a megyéhez, illetve járáshoz, csupán az „európai középszinthez", azaz a régióhoz.

Az országos szint természetesen kiemelt jelentőséggel bír a megkérdezettek gondolkodásában, ezért a nemzetállamhoz kötődést minden esetben bevették az Eurobarometer vizsgálatokba is. Az országos szinthez természetesen egyaránt kapcsolódik területi és nemzeti identitás is, ezek elválasztása csak nehézkes módon válhat lehetségessé. Ezért Bugovics (2007) vizsgálatához hasonlóan jelen mü szerzője operacionális szinten azonosnak tekinti az országhoz és a nemzethez való kötődést.

\subsection{KÖVETKEZTETÉSEK}

A fejezet tanulságai alapján belátható, hogy a területi identitás koncepciója egyfelől bonyolultsága, másfelől a társadalmi tőkéhez hasonlatos sokdimenziós, már-már metaelméleti szinten összetett jellege miatt aligha operacionalizálható empirikus mérésre adekvát módon. Másfelől nem is gondoljuk azt, hogy a nemzetállami szinthez képest „,fiatal”, föleg az újonnan, 2004 után csatlakozott 12 ország számára teljesen új Európai Unióhoz lakosai tudnának a területi identitás elmélet hagyományos dimenzióinak megfelelően identifikálódni. Kötődéseket azonban feltételezünk, mind a megszokott, jól ismert területi szintekhez, mind az új, az EU csatlakozást megelőző reformok eredményeként létrejött szintekhez egyaránt. Szerencsés helyzetben vagyunk, mivel a területi kötődés - melyet a téma kutatói egybehangzóan a területi identitás egyik legfontosabb, mérésre talán legkönnyebben alkalmazható dimenziójának tartanak - egy széles körben teoretizált és kutatott jelenség. A kötődéseket folyamatosan méri az évente négy hullámban zajló Eurobarometer longitudinális kérdőíves vizsgálat. E mü szerzője még 2004-ben lehetőséget kapott a szegedi lakosság területi kötődéseinek vizsgálatára a Szeged Studies nagymintás empirikus kutatás keretében. A területi kötődésről így kellő mértékben állnak rendelkezésre elméleti és empirikus források. A koncepció alkalmas arra, hogy az elméleti kérdések empirikus indikátoraként alkalmazzuk a statisztikai elemzések során. 


\section{A TÁRSADALMI TŐKE ÉS A TERÜLETI IDENTITÁS VISZONYA}

Amennyiben a közös elemeket keressük a társadalmi tőke és a területi identitás elméletekben, azok természetesen adottak, és a hasonlóságok egy részéről már szót is ejtettünk. Megemlítettük, hogy a hasonló kiemelt cél, a társadalmi integráció és a társadalmi kohézió vizsgálata és azok növelési lehetőségeinek feltérképezése érdekében foglalkoznak elméleti és gyakorlati szakemberek a két elgondolás különböző dimenzióival. Gyakorlati vetületeik megtalálását és a tervezés és programozás általi mindennapi felhasználásuk elősegítését tervezi például az Európai Unió mindkét teória esetében, főként kohéziós politikai céljainak elérése érdekében. Az EU kulcsszerepe kiemelendő abban is, hogy a közösség regionális területi egyenlötlenségeit tárgyaló harmadik kohéziós jelentésben bevezették a két elmélet egyféle ötvözésének, a területi tőkének a fogalmát. ${ }^{5}$ Tudományos reflexiók a területi töke fogalmára eddig kis számban születtek. Kiemelendő azonban Camagni (2009) tanulmánya, melyről már szót ejtettünk a társadalmi tőke és a többi tőketípus viszonyát bemutató résznél. A kutató által használt területi tőke konstrukció jól példázza az európai kohéziós politikai tervezés hatását a tudományos szférára, a tanulmányban kifejezetten egy fejlesztést és regionális növekedést elősegítő erőforrásfajtát tár elénk. Ezen írás, illetve több más szakirodalmakat áttekintő munka szemlézése (Cartwright et al 2006; Füzér et al. 2005) alapján valószínüsíthető, hogy a jövőben a fogalom használata szélesebb körben elterjed.

Természetesen figyelembe kell venni azt a tényt, hogy a két elmélet erősen „terhelt" tartalmi szempontból, azaz igen sok szerző fogalmazott meg nagymértékben különböző véleményt az elméletekkel kapcsolatos tudományos produktumokban. Vélekedésünk szerint mindkét elmélet gyüjtőelméletnek tekinthető. A tudományos

Harmadik kohéziós jelentés, 2004. február. Internet: http://ec.europa.eu/regional_policy/sources/ docoffic/official/reports/cohesion3/cohesion3_en.htm (Elérés ideje: 2009.03.20 15:00) 
életben nincs konszenzus egyik elmélet pontos tartalmával, illetve az egymáshoz való viszonyukkal kapcsolatban sem.

E munkában irodalomszemlém és az elvégzett konceptualizálás eredményeként azt feltételezem, hogy a területi identitás, illetve mérésre operacionalizálható része a területi kötődés a társadalmi tőke elmélet egy dimenziójaként funkcionál a területi egységek helyi társadalmainak esetében. Azaz a meglévő bizalom, szolidaritás, részvétel, tolerancia és területi identitás és kötődés határozza meg az adott térség társadalmi profilját, mely sok más dimenzióra is hatással van. Befolyásolja a gazdasági, a politikai és a vallási dimenziót, illetve még a természeti környezet állapotát is. Ezt az elgondolást egyrészt e fejezet elméleti fejtegetéseivel, másrészt kutatásom empirikus részének eredményeivel kívánom alátámasztani. Nem kívánom azonban az elgondolás igazságát mindenáron hangoztatni, inkább egyféle munkadefiníciónak gondolom. Az alább látható 4. táblázat összefoglalóját adja a két elméleti csokor általam legfontosabbnak tételezett közös dimenzióinak.

\section{4. tábla - a területi identitás és a társadalmi tőke főbb dimenzióinak összefüg- gései és különbségei}

\begin{tabular}{|l|l|l|l|}
\hline Főbb dimenziók & Társadalmi töke & $\begin{array}{l}\text { Területi iden- } \\
\text { titás }\end{array}$ & Azonos \\
\hline Bizalom & & & \\
\hline Általánosított bizalom & + & + & + \\
\hline Interperszonális bizalom & + & + & + \\
\hline $\begin{array}{l}\text { Bizalom a politikai rendszer különböző } \\
\text { területi szintjein }\end{array}$ & + & + & + \\
\hline Reciprocitás & & & \\
\hline $\begin{array}{l}\text { Azonnali viszonzás igénye nélküli szimmet- } \\
\text { rikus reciprocitás }\end{array}$ & + & + & + \\
\hline Organikus szolidaritás & + & + & + \\
\hline Mechanikus szolidaritás & + & + & + \\
\hline Részvétel & & & \\
\hline Részvétel a közéletben & + & + & + \\
\hline Tolerancia & & & \\
\hline Tolerancia másokkal szemben & + & + & + \\
\hline Társadalmi hálózatok & & & \\
\hline Társadalmi hálózatok kompaktsága & + & + & + \\
\hline Kohézió,integráció & & & + \\
\hline A területi kohéziót növeli a magas szintje & + & + & \\
\hline
\end{tabular}

Forrás: Coleman 1988, 1990; Cox 1995; Putnam 1993, 1995, 2000; Marks 1998, Moreno 1999; Lengyel 2003; Brutter 2005; Bugovics 2008 alapján saját szerkesztés 
A bizalom, a szolidaritás és reciprocitás, a részvétel, a tolerancia, a társadalmi hálózatok és a társadalmi kohézió, illetve integráció kérdései egyaránt megjelennek a vizsgált elméletek szakirodalmában, ezáltal indirekt bizonyítékot nyújtva azok összekapcsoltságára. A kutatás elméleti részében részletesen bemutatom az egyes dimenziókat, illetve azok összefüggéseit, kölcsönhatásait. A célom, hogy empirikus összefüggést találjak a társadalmi tőke és a térségi kötődés között, a magyar régiók vizsgálatával és összehasonlításával. Véleményem szerint a területi - így régiós - társadalmi tőkének kiemelt eleme és indikátora a területi kötődés. Ezáltal ha az egyik vagy a másik koncepciót mérem, mindenképpen információkhoz jutok mind a kettővel kapcsolatban.

A 4. ábra mutatja be a területi identitás és területi kötődés társadalmi tőkéhez és annak dimenzióihoz füződő viszonyát a kutatásaim során kialakított elképzelésem szerint. A területi identitás egyik legfontosabb eleme a területi kötődés, melyet az Eurobarometer kérdőív különböző hullámainak adatai alapján ezen kutatás empirikus részében a területi identitás mérésére fel tudtunk használni.

\section{4. ábra - A társadalmi töke legfontosabb dimenziói}

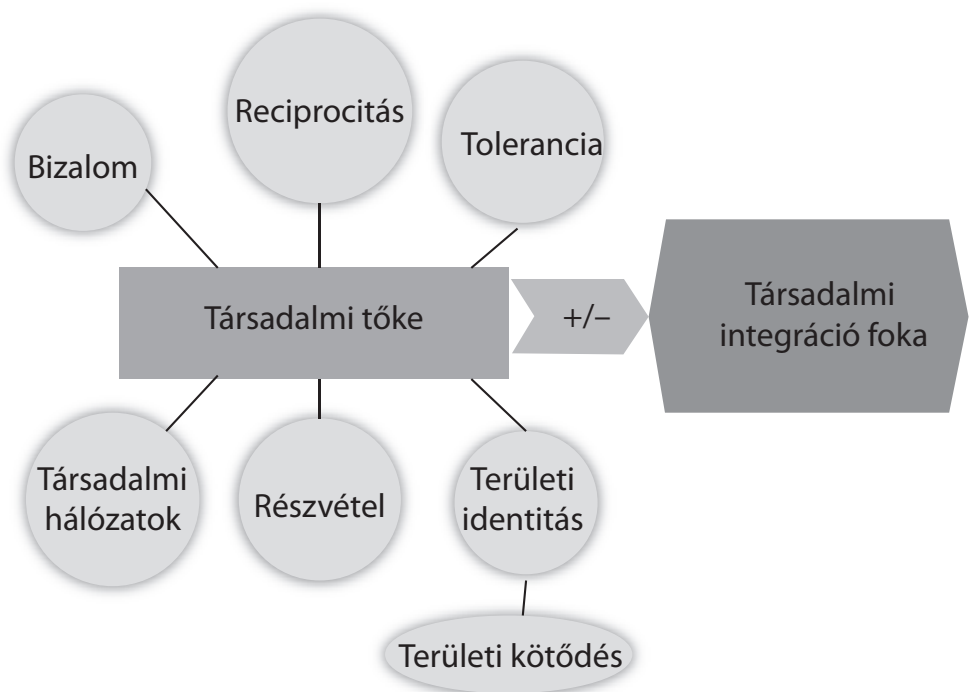

Forrás: saját szerkesztés 


\subsection{NÉHÁNY PÉLDA A KÉT ELMÉLET EGYÜTTES HATÁSÁRA}

Tudvalévő dolog, hogy a régiók közötti különbségek egy része, például a versenyképességbeli különbségek nem magyarázhatóak kizárólag mérhető mutatókkal. Előfordulhat, hogy két látszólag hasonló adottságokkal rendelkező térség eltérő eredményeket fog produkálni a gazdasági folyamatokban, valamelyik kevésbé lesz versenyképes, mint a másik, s a különbség oka a mérhető mutatók között nem lesz fellelhetö. Az egyik nem, vagy csak nehezen, hosszú operacionalizálás után mérhető tényező a társadalmi tőke, a másik pedig az ahhoz kötődő térségi identitás szintje. Ezeket a nehezen mérhető mutatókat azonban mégis érdemes tanulmányozni, azok bekerülnek jelentős közgazdasági elméletekbe is.

Alátámasztja az 5. ábrán vázolt sémát és az első bekezdésben írtakat az a Robert D. Putnam és szerzőtársai (1993) által végzett vizsgálat, majd publikált könyv, mely az olasz regionális kormányok társadalmi tökéje és a területi kötődéssel való összefüggések tekintetében tárt fel összefüggéseket. A sikeresebb térségekben erösebb volt a területhez való kötődés és nagyobb mértékü volt a társadalmi tőke - ez a bizalom, a szolidaritás és a tolerancia magasabb szintjein mutatkozott meg. A kevésbé sikeres térségek esetében a bizalom hiánya, a térséghez való lazább kötődés és a kooperáció megvalósíthatósága gátolta meg az előrelépést.

Másik fontos példa Lengyel Imre vizsgálata. Lengyel (2003) a térségek társadalmi kohézióját sikerességi faktornak, a társadalmi tőkét egyértelműen a sikerességet meghatározó alaptényezőnek tekinti munkájában. A társadalmi tőke a regionális versenyképesség fogalmával párhuzamosan kerül elő. Bár Lengyel megközelítése föként gazdasági jellegü, a versenyképesség fogalmát ${ }^{6}$ a regionális versenyképesség fogalmának meghatározásakor kiegészíti két tényezővel: környezeti és társadalmi szempontokkal. A szerző elméletében a társadalmi tőke és a regionális kötődés így kerülnek be azon kulcstényezők közé, amelyek meghatározzák a regionális versenyképességet. A társadalmi tőkét fejleszthetőnek tételezi, mellyel növelni lehet a társadalmi kohéziót. A társadalmi kohézióval párhuzamba állítja a regionális identitást, és azt mondja, hogy a magas kohézió és a magas szintű identifikálódás együtt jár, és ez a két tényező a társadalmi tőke elemének tekinthető.

Az 5. ábra bemutatja a társadalmi tőke és a regionális identitás hatását a regionális versenyképességre, illetve egymásra való hatásukat, Lengyel elgondolása ${ }^{6}$ „A versenyképesség a fenntartható gazdasági növekedéshez, a globális versenyben elérhető gaz-
dasági növekedéshez kapcsolódik.” (Lengyel 2003. 256. o.) 
és Putnam és szerzőtárai kutatási eredményei alapján. A magas szintű társadalmi tőke növeli a regionális identitás szintjét is és ez fordítva is igaz. A társadalmi tőke és a regionális identitás magasabb szintje egyértelmű pozitív hatással van a regionális versenyképességre. A gazdasági siker, a jó regionális versenyképesség pedig törvényszerủen visszahat a társadalmi tőke és a regionális identitás szintjére. A többi, regionális versenyképességet befolyásoló tényezőt nem ábrázoltuk, mivel azok jelen munka szempontjából nem relevánsak.

\section{5. ábra - Vázlat a társadalmi tőke és a regionális identitás együttes hatásairól a regionális versenyképességre}

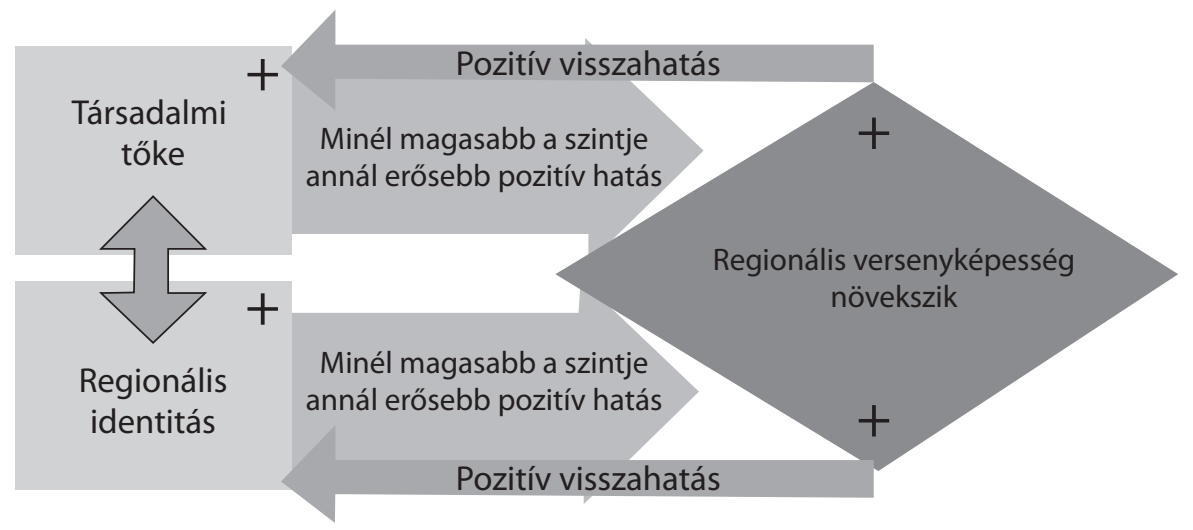

Forrás: Putnam et al 1993 és Lengyel 2003 alapján saját szerkesztés

A társadalmi tőke elemei közül Lengyel még kiemelte a területen müködő regionális hálózatokat, amelyek szerepet vállalnak a konfliktusok feloldásában és a közös célok kijelölésében. Itt is visszaköszön a kompakt nektworkök iránti igény, mivel azok egyértelmüen a térség segítségére tudnak lenni a versenyképesség növelésében. Kiemelt fontosságú elem az erős társadalmi kohézió, valamint integráltság, melyek hozzájárulnak a hálózatok kompaktságához és a társadalmi tőke, valamint a területi identitás erösítéséhez.

Lukovics (2004) cikkében a regionális identitás szerepéröl a régiók gazdaságfejlesztésében felhasználja a regionális identitás koncepcióját és Robert D. Putnam (2000) elméletét a „Bowling Alone” című munkából, amely egyértelmüen a két elmélet összekötésére utal. A szerző ebben a tanulmányában nem jutott túl az idenitás elméleti kereteinek körbejárásánál, ám abba beilleszthetőnek vélte 
Putnam elméletét, ezáltal is bátorítva bennünket a regionális szintű területi kötődés és társadalmi tőke elméleti kompatibilitásának feltételezésére.

Roberto Camagni (2009) tanulmánya szintén együttesen használja fel a területi kötődést és a társadalmi tőkét, ám azokból egy új erőforrás típust, a területi tőkét konstruálta meg. A területi tőke nem kizárólag a társadalmi tőkére és a területi identitásra épül, hanem más dimenziók is helyet kaptak benne, ahogy az korábban olvasható volt.

\subsection{AZ ELEMZÉS CÉLJA}

A két vizsgált elmélet, a társadalmi tőke és a területi identitás elmélet tehát sok közös, átfedő dimenzióval rendelkezik. Munkámban Lengyel Imre (2003) elgondolásának és saját elméleti feltevésemnek megfelelően a területi identitást, valamint a társadalmi töke elméleteket összefüggőnek, a regionális identitást a társadalmi tôke egy régiós szintü megjelenési formájának tekintem.

A fent vázolt elméleti összefüggések alapján merült fel ezen írás vonatkozó hipotézise, melyet nagy részben formált Robert D. Putnam (1993) munkája. Ahogy már említést tettünk róla, a „Making Democracy Work” címü könyv egy empirikus kutatás eredményeit bocsátotta közre, melyet a szerző Olaszországban a demokratikusan választott olasz regionális önkormányzatok müködésével, sikerességével kapcsolatban végzett. A kutatást néhány kiválasztott, földrajzi szempontból egymástól távoli és a kulturális hagyományok szempontjából eltérő tulajdonságokkal rendelkező olasz régió önkormányzatai esetében végezték. Fö eredménynek az a megállapítás tekinthető, hogy a jobban müködő regionális önkormányzatok esetében a térség társadalmi tőke szintje magasabb, a rosszabbul teljesítő önkormányzatok esetében alacsonyabb volt. Ezt az állítást megfordítva azt mondhatjuk, hogy azokban a régiókban, ahol magasabb volt a társadalmi tőke szintje, a regionális önkormányzatok is jobban müködtek, mint alacsonyabb társadalmi tőke szinttel bíró társaikban. Putnam könyvében hangsúlyozta, hogy nem maguk a regionális intézmények, hanem a társadalmi környezetük volt igazán meghatározó müködésük szempontjából. Az önkormányzatok sikeressége és sikertelensége tehát egyértelmúen összefüggött a térség helyi társadalmának társadalmi tőke szintjével. Putnam történeti kontextusban is vizsgálta a kérdést, és már ő is felvetette a területi (regionális) identitás fontosságát is ebben a bonyolult viszonyrendszerben. A 6. ábrán látható egy a fentebb említett viszonyrendszer grafikus ábrázolására tett kísérlet. 


\section{6. ábra - Vázlat a társadalmi tőke és a területi identitás együttes hatásairól a területi önkormányzat sikerességére}

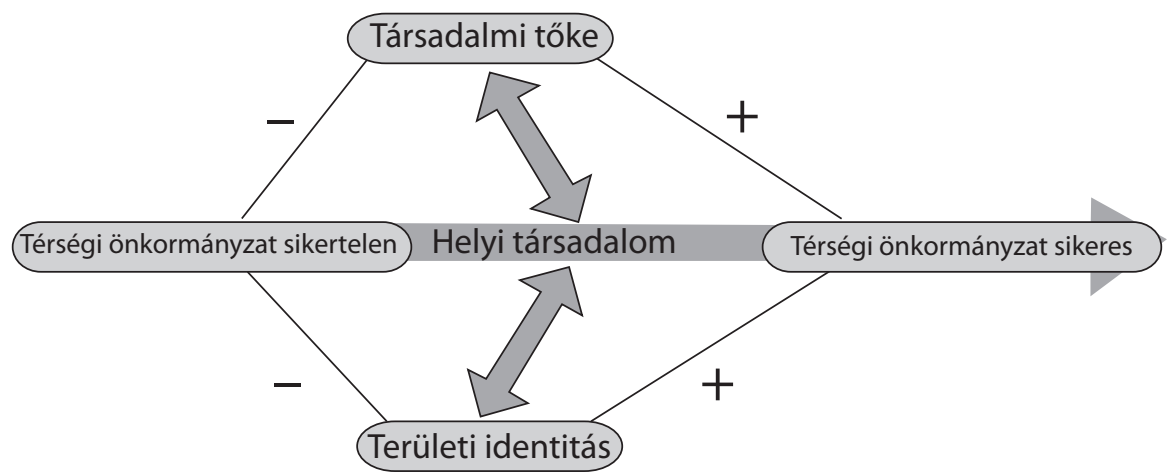

Forrás: saját szerkesztés Putnam et al. 1993 alapján

Ha továbbhaladunk ezen a gondolati fonálon, arra juthatunk, hogy azokban a térségekben, ahol hagyományosan müködtek összetartó erők, valamint sikeres társadalmi hálózatok, a társadalmi tőke pozitív hatásai ki tudtak bontakozni. Azt is mondhatjuk, hogy a társadalmi tőke magas szintje hozzájárult a térségek önkormányzatainak sikeres müködéséhez. Ezek az összetartó erők segítették elő a helyi társadalom összetartását és magasabb szintű kohézióját. Elgondolásom szerint a helyi társadalommal való identifikálódás a magas szintű társadalmi tőke előfeltétele az adott közösségben. Továbbá a területi identitásnak kulcsszerepe van a térségi politikai szereplők sikeressége szempontjából, illetve a társadalmi tőke szintjének szempontjából egyaránt. Ahol müködik az emberek közötti és az intézményekbe vetett kölcsönös bizalom, ahol az emberek hajlandóak az azonnali viszonzás elöfeltétele nélkül is segítséget nyújtani egymásnak, és ahol a lakosok közül bárki kaphat, illetve adhat bizalmat bárkinek, adottak a feltételek egy térségi identitás megszilárdulásához. Az is elmondható, hogy azokban a térségekben, ahol erős az összetartozás, a közös sors és közös érdekek érzése, illetve felismerése, sokkal könnyebben fognak megteremtődni a szükséges feltételek a társadalmi tőke magasabb szintjének eléréséhez és annak folyamatos növeléséhez. A régiók helyi társadalmai véleményem szerint ilyen közegekké válhatnak, illetve közegek lehetnek - ezeknek a helyi társadalmaknak a sikeres müködése magukat a térségeket is sikeressé teheti, a sikertelen müködés pedig a térséget is sikertelenné teszi. A területi 
identitás értelmezéséhez a fentiek szerint tehát jól használhatónak mutatkozik a társadalmi tőke elmélet, mint magyarázó, illetve összekapcsolt keretelmélet felhasználása.

Célom a magyar társadalom véleményeinek és helyzetének illetve a régiók helyi társadalmainak - már ha beszélhetünk ezekről - a helyzetének és véleményeinek összehasonlítása a vizsgálat során. Feltételezésem szerint, ha néhány szerző szerint nem is beszélhetünk regionális helyi társadalomról, hiszen Magyarországon a regionális reformok főként „top-down” jelleggel lettek végrehajtva, a régiós a helyi társadalmak összességéből összeállt régió azonban mindenképpen értelmezhető egyfajta „bottom-up” módon összeállt helyi társadalomként. Az elemzések során egy „szük” régió definícióval dolgozom: a magyar NUTS 2-es statisztikai - tervezési - közigazgatási régiókat kívánom megvizsgálni. Ez a lehatárolás egyfelől megfelel elgondolásomnak, miszerint a magyar régiók alkalmas keretei a területi kötődés és a társadalmi tőke kialakulásának, valamint az európai egység részeiként magát az EU-t jelentik lakosaik számára. Másfelöl ez a lehatárolás tette lehetővé a megfelelő kutatási adatforrások kiválasztását, illetve a megfelelő elemzési/statisztikai módszerek megválasztását. 


\section{A REGIONÁLIS LAKOSSÁGI FELMÉRÉSEK VÉGZÉSÉNEK ÉS ÖSSZEHASONLÍTHATÓSÁGÁNAK KIHÍVÁSAI}

A társadalomtudomány kutatói a kialakult nemzetközi gyakorlatnak megfelelően stabil know-how-k mentén és parázs módszertani viták eredményei alapján hasonlítják össze az egyes országok lakossági adatait különböző módszerekkel. Ilyen kiérlelt, egységesült nemzetközi gyakorlatról azonban a regionális adatok összehasonlításának módszertana esetében még nem beszélhetünk. E fejezetben azt vizsgálom, hogy napjaink társadalomtudományi kutatásai hogyan kezelik a regionális adatok összehasonlíthatóságának kérdését. Több különféle módszertani variáció ismert a regionális összehasonlításra: 1. főként kvalitatív szemléletü összehasonlítás, 2. föként kvantitatív szemléletü összehasonlítás, illetve 3. vegyes adatgenerálási módszerekkel gyüjtött adatok összehasonlítása. Az összehasonlítás lehet nemzeti vagy nemzetközi szinten értelmezett, azaz összehasonlíthatjuk egy ország, illetve különböző országok régióit. Vajon megfelelö-e az országok adatainak összehasonlítására használt módszerek alkalmazása a régiós összehasonlítások esetében? Jelen fejezetben erre a kérdésre keresem a választ, illetve kísérletet teszek egy lehetséges regionális összehasonlítási normarendszer megtalálására. Bemutatom azokat a nemzetközi összehasonlító kutatásokat, melyeknek adatbázisait a regionális összehasonlítás céljára kívánom felhasználni. Továbbá elvégzem a mérési invarianca tesztelését konfirmációs faktorelemzéssel az általánosított bizalom koncepciója esetében a magyar régiók ESS/EUTE kérdőívből származó adatain. 


\subsection{PÉLDA A REGIONÁLIS ÖSSZEHASONLÍTÁS SZÜKSÉGESSÉGÉRE: A REGIONÁLIS POLITIKÁK HATÁSÁNAK ÉRTÉKELÉSE}

Régóta létező követelmény az intézményi és kormányzati szakpolitikákkal szemben, hogy hatásosak és eredményesek legyenek, és nem új keletủ dolog az ezen szempontokat felderítő társadalomtudományi hatásvizsgálatok bevezetése sem. A tudósok és a szakpolitikusok közös érdeke, hogy akár sok energia befektetésének árán is értékelési technikákat fejlesszenek és alakítsanak ki, melyek képesek a különböző kormányzati szakpolitikák hatását hatékonyan, összehasonlító módon megvizsgálni.

A regionális politikák hatásvizsgálatának fontossága a '90-es évek folyamán emelkedett meg nagymértékben, amikor azonnali igény mutatkozott sokféle, nagy mennyiségủ közpénzből finanszírozott regionális fejlesztési projekt és program módszeres értékelésére. Az Európai Unió különböző ügynökségei sokat tettek egy egységes, átfogó és hatékony értékelési rendszer kiépítése érdekében, hiszen feladataik közé tartozott a különböző országok különböző régióiban zajló regionális fejlesztések általános értékelése. Ugyanekkor a különböző régiókban működő fejlesztési ügynökségek maguk is értékelési módszertan kialakítására törekedtek, azért, hogy javítsák a teljes értékelési folyamat átfogó eredményét.

A szakpolitikai döntéshozóknak az alábbi kérdésekre kell választ kapniuk a regionális szintủ szakpolitikák alkalmazásával kapcsolatban:

- Ex ante kérdés: „mi az, amit a regionális politika várhatóan elér?”. Ex post kérdés: „mi az amit a regionális politika elért?”.

- Milyen valószínű hatásai lesznek a regionális politikának, és milyen módszerek állnak rendelkezésre ezen hatások megbecslésére?

- Milyen eszközök a leghatékonyabbak a regionális politika céljának elérése érdekében?

- A korábbi tapasztalatok nyújtanak-e bármilyen használható támpontot a politikai eszközök hatékonyságával és hatásosságával kapcsolatban?

A fenti kérdésekhez hasonló kérdésekre adott válaszok kritikus fontosságúak a regionális politikák tervezői számára szakpolitikai céljaik elérése érdekében. Az első lépés tehát a szakpolitikák értékelésében a politika céljának világos meghatározása. Tudnunk kell, hogy a politikai döntéshozók mit terveznek elérni, ha a politikák 
pozitív hatásai megfelelően müködnek (Armstrong-Taylor 2000, 362-363o.). Vannak átfogó és konkrét célok, amelyekröl beszélhetünk. Átfogó cél például a társadalmi integráció és kohézió növelése a régiókban. Konkrét cél egy intézkedés, vagy projekt, ami valamilyen konkrét tevékenységen keresztül segíti elö az átfogó célok elérését. A regionális összehasonlítások, tudományos vizsgálatok elvégzése az átfogó és konkrét célok felállítása és gyakorlatba ültetése után kell, hogy következzen. A regionális összehasonlítások elvégzésének szükségessége tehát vitán felüli fontosságú része a folyamatnak, amelyet el kell végezni a megfelelő döntés előkészítés, illetve a regionális szakpolitika hatékonyságának mérése érdekében.

\subsection{AZ ÖSSZEHASONLÍTÁS LEHETSÉGES MÓDSZEREI ÉS KERETEI}

Az összehasonlításra vonatkozóan a szakmai konszenzus a nyolcvanas évek végére, kilencvenes évek elejére, a nemzetközi összehasonlító elemzések megsokszorozódásának korszakára megszületett. A kialakult konszenzus tartósnak és hatékonynak tünik; a nemzetközi összehasonlító vizsgálatok ma reneszánszukat élik, föleg a kvantitatív kutatások körében (a teljesség igénye nélkül: WVS/EVS ${ }^{7}, \mathrm{ESS} /$ EUTE $^{8}$, EUROBAROMETER $^{9}$, ISSP $^{10}$, ISJP $^{11}$ AUFBRUCH $^{12}$ ), és a kutatók módszertani felkészítésük keretében - általában már a mesterképzés során - megtanulják az egyszerübb nemzetközi összehasonlítások módját, a tendenciák és trendek nemzetközi színtéren történő elemzését. A nemzetközi összehasonlító elemzések módszertanával, a kutatási gyakorlattal kapcsolatban sok publikáció jelenik meg a vezető szakmai folyóiratokban. A régiós adatok összehasonlítására azonban még nincsen kialakult tudományos konszenzus, ezért tartom fontosnak, hogy áttekintsük a nemzetközi összehasonlító módszer megközelítéseit az esetlegesen alkalmazható jó gyakorlatok után kutatva.

7 World Value Survey / European Value Survey. További információ: http://www.worldvaluessurvey.org/

8 European Social Survey. További információ: http://www.europeansocialsurvey.org/; www.esshu.hu

9 EUROBAROMETER kutatás. További információ: http://ec.europa.eu/public_opinion/index_en.htm

10 International Social Survey Programme. További információ: http://www.issp.org/

11 International Social Justice Project. További információ: http://www.butler.edu/ISJP/

12 AUFBRUCH - New Departures Project. További információ: http://www.vallastudomany.hu/ tanszek/kutatas/aufbruch/index 
A komparatív nemzetközi empirikus kutatásnak két nagy válfaját lehet megkülönböztetni a kortárs társadalomtudományi irodalmak alapján: Az első a kvalitatív eset-orientált, amelyben az esetek megértő összehasonlítása fontosabb, mint az általánosítás lehetősége. A második pedig a kvantitatív változó-orientált, amelyben az általánosíthatóság fontosabb, mint a komplexitás. Az első válfajt föleg a történetszociológiában és a policy kutatásokban alkalmazzák gyakran. A második megközelítést főként általános és elméleti szociológiai magyarázó modellek tesztelésére használják a kutatók (Ragin 1987; idézi: Arts-Halman 1999, 3 o.).

Az eset-orientált és változó-orientált megkülönböztetéseket Charles C. Ragin vezette be 1987-ben írt korszakos jelentőségü munkájában (Ragin 1987), melyben lefektette a modern komparatív társadalomtudományi kutatás módszertani alapjait. A fenti, nagyon fontos módszerbeli megkülönböztetés mellett Ragin néhány további módszertani megfontolásáról is érdemes szót ejteni.

Megállapította, hogy szinte minden empirikus társadalomtudományi kutatás magában foglal valamiféle összehasonlítást. Az összehasonlítás tesz minket képessé arra, hogy empirikus tapasztalataink alapján állításokat tehessünk a törvényszerüségekről, és lehetőséget ad az esetek interpretációjára taralmi vagy elméleti szempontok alapján. Ebben az értelemben az összehasonlítás és összehasonlíthatóság kérdése központi kérdés a mai empirikus társadalomtudományi kutatásokban (Ragin 1987, 1 o.).

A két metódus közül a változó-orientált összehasonlító megközelítés lehetőséget ad a különböző társadalmi jelenségek makró szintű megfigyelésére és elméleti általánosítására, természetesen úgy, hogy nem hagyja teljesen figyelmen kívül a különböző társadalmi jelenségek különböző fokú komplexitását. Ezen módszer alkalmazásánál a kutató nem olyan jó ismerője az egyes összehasonlított egységeknek, mint az eset alapú megközelítés alkalmazása esetében általában. A megközelítés ezen gyengesége az eredményeket relativizáló veszélyeket hordozhat magában, az elmélyültebb esetismeret szinte mindig jobb minőségü, megbízható összehasonlítást eredményez (Ragin 1987, 57 o.).

A változó-orientált megközelítés alkalmazásával az elmélet(ek) szigorú tesztelése statisztikai módszerek segítségével könnyedén elvégezhető. Az elméletek és hipotézisek tesztelésekor sokkal nagyobb teret nyerhetnek a kutatás közben megfogalmazott alternatív magyarázatok, mint az eset alapú megközelítés alkalmazásakor. A módszer elterjedése hozzájárult az összehasonlítások elterjedéséhez és uniformizálódásához, mert lecsökkentette az összehasonlító kutatások szakértelem igényét, illetve könnyen értelmezhetővé tette az egyes kutatók számára más 
kutatók eredményeit. A módszer térnyerése egyaránt megakadályozta az elvakult általánosítások elterjedését és a partikularitásokkal történő makro-szintủ magyarázatok túlzott dominanciáját (Ragin 1987, 57-58o.).

Ahogy a fentiekben is jeleztük, a két módszer lehetséges alkalmazóinak sok dologra kell felkészülniük. A változó-orientált megközelítés nagyobb esetszám feldolgozását képes elvégezni alacsonyabb fokú komplexitás mellett, melyet az okok, és mozgató-rugók leegyszerüsítése tesz lehetővé. Az eset-orientált megközelítés ellenben inkább engedi a kutatóknak a sokszínüség megértését és a problémák komplexitásának jobb átlátását, azoknak kontextusban való elhelyezését. Ez a módszer azonban akkor kerül szinte lehetetlen helyzetbe, amikor nagyszámú, különböző esetek feldolgozásával kell megbirkózni a vizsgálatban. Ragin nem javasolja, hogy a két módszert külön alkalmazzuk, sokkal inkább kombinált alkalmazást képzel el. Véleménye szerint a jó minőségü összehasonlító kutatás a két módszer racionális kombinációján alapul (Ragin 1987, 168 o.).

A kortárs, Magyarországon végzett társadalomtudományi kutatások tapasztalatai megmutatták, hogy a kiválasztott módszerek megfelelősége, adekvátsága nagy hatással van a kutatás eredményeinek érvényességére. Sok olyan kutatás készül el, ahol az elméleti megközelítések és a kutatási módszerek ötvözése jó, ám sajnos még több, ahol az egyik terület, a módszertan vagy az elmélet túlsúlyba kerül, a másik pedig visszaszorul. A fenti fejtegetés is azt az érzést adhatja az olvasónak, hogy ez egy túlzottan bonyolult módszertani kérdés, sokkal fontosabb a kutatás tartalma, mint az ilyen aprólékosan megrajzolt és kijelölt keretek. Azonban mivel a cél a módszertan és az elméleti megközelítések minőségi ötvözése és érvényes adatok gyüjtése, fontos az ilyen jellegü módszertani kérdések áttekintése is.

A fentiekben felvázolt megközelítések tehát nem a vizsgált esetek jellegéből fakadóan, hanem a választott összehasonlítási módszerek eltérő tulajdonságai és produkált eredményei miatt térnek el egymástól a leginkább. Ennek fényében kevésbé befolyásolja az összehasonlítás eredményét, ha az elemzés egységei régiók, nem pedig országok - mintha az eset-orientált vagy változó-orientált módszert használjuk az egyes esetek összehasonlítására. Az alkalmazott összehasonlítási módszer tehát fontosabbnak tủnik a vizsgálat eredményei szempontjából, mint az elemzés tárgya. Ez természetesen kis túlzásnak tủnik, azonban módszertani szempontból megfontolva az ügyet, adaptálhatjuk a megközelítést.

A területi összehasonlítás társadalomtudományi módszertanának áttekintése után fontos adalékokkal szolgált a regionális tudomány területi összehasonlító módszerének áttekintése. Nemes Nagy József és kollégái három típusát különböztetik 
meg a területi összehasonlításnak az összehasonlított területi egységek száma alapján. Az első típus egy területi egység beható vizsgálatát jelenti, a második típus több területi egység összehasonlító vizsgálatát, míg a harmadik típus a területi egységek rendszerének vizsgálatával foglalkozik (Nemes Nagy 2005, 3 o.).

Az első típushoz köthetőek a szerző által területi esettanulmánynak nevezett módszerrel készült írások, melyekben a komparatív szempont általában csupán vizsgálati keretként vagy háttérként bukkan fel, az esettanulmány általában egyedi jelenségekre koncentrál. A második típushoz köthető az a próbálkozás, amikor több területi egység együttes elemzése a cél. Itt már erősebb a komparatív szemlélet, az elemzés célja a területi egységek közötti azonosságok és különbözőségek bemutatása. Fontos megjegyzés, hogy az eltérések mellett kell, hogy legyenek egyértelmü azonosságok is a területi egységek között, például a méretük, gazdasági vagy társadalmi jellemzőik. Ezen azonosságok teszik a fellelt különbségeket érdekessé. A harmadik típushoz köthető próbálkozás például egy ország összes régiójának vizsgálata vagy egy kontinens összes nagyvárosának bevonása az elemzésbe. A vizsgálat tárgyai itt a közös és egyedi sajátosságok, a lokális, regionális és globális különbségek. A szerzők megjegyzése szerint ehhez a vizsgálati úthoz kötődik leginkább a matematikai statisztikai módszerek alkalmazásának lehetősége (Nemes Nagy 2005, 3-4 o.).

Horváth Gyula egyértelmúen kifejezte, hogy a regionális-területi kutatások bonyolultságát egyfelől az interdiszciplináris nézőpont alkalmasságának a szükségessége, másfelől a bonyolult, területi szintek és aktorok közötti kölcsönhatás-rendszer határozza meg. A térben zajló gazdasági és társadalmi folyamatok vizsgálata éppen ezért szétfeszítette a hagyományos diszciplináris kereteket, és a regionális tudomány kialakulása felé mutat. Horváth definíciója a regionális tudományra: „,a térrel foglalkozó társadalomtudományok közös alapfogalmait, elméleteit és módszereit egységes rendszerbe foglaló, a társadalmi-gazdasági jelenségeket és folyamatokat ezek felhasználásával vizsgáló tudomány” (Horváth 2002, 307 o.).

Horváth nézete szerint a közgazdaság-tudomány és a gazdaságföldrajz egyaránt joggal tekintheti magát a regionális tudomány bölcsőjének. Ugyanakkor Horváth megjegyzi, hogy a magyarországi társadalomtudományok közül a szociológia intézményesülésére is jó hatással volt, hogy fontos következtetéseket tudtak levonni területi folyamatok hatásaiból például a települési különbségek feltárásánál. A politikatudomány esetében fontos legitimáló tényező volt a területi közigazgatási hatalom vizsgálata (Horváth 2002).

A társadalomtudományi és regionális tudományi összehasonlító módszerek közötti legfontosabb különbség a megközelítésben rejlik. Míg a társadalomtudományi 
összehasonlítás legfontosabb jellemzőit a módszerválasztás (Pászka 2007) határozza meg, addig a regionális tudományban az összehasonlítás kerete a tér, általában egy területi egység operacionalizált formájában, mely ebben az esetben a legfontosabb meghatározó. Persze a tisztán politikatudományi összehasonlításnál a legfontosabb összehasonlítási szempont a hatalomgyakorlás elemzése, a tisztán szociológiainál a helyi társadalom vizsgálata és a tisztán gazdaságinál a helyi gazdaság szférájának feltérképezése. Pálné Kovács Ilona (1990) a helyi hatalomról és helyi társadalomról szóló könyvében alkalmazott politikatudományi módszertanának megfelelően vizsgálódásának fókuszául a helyi hatalmat választotta. A helyi hatalom véleménye szerint a helyi társadalom különböző alrendszereiben megjelenő hatásmechanizmusain keresztül nyilvánul meg, és alkalmazható kényszerítő eszközein alapul (Pálné Kovács 1990, 75 o.).

Pálné maga is feloldja a diszciplináris elhatárolások miatt kialakulni látszó ellentéteket a helyi hatalom definíciójának finomításával és lehetséges értelmezéseinek pontosításán keresztül. A szerző által idézett Offe (Pálné Kovács 1990) kettős legitimációs modelljében kettéválik az állam gazdasági függése és legitimációs bázisa, mely a helyi gazdasági szféra nyomását tételezi jelentősnek a helyi hatalom szempontjából. A Pálné által ismertetett francia közösségvizsgálatok pedig inkább a közvetlen társadalmi környezetet tartották jelentősebb befolyásoló tényezőnek a helyi hatalom szempontjából, mint a központi akaratot. Ezeket a tényeket figyelembe véve és következményeiket felismerve a szerző a helyi hatalmat nem tartja vizsgálhatónak vertikális környezetének vizsgálata nélkül (Pálné Kovács 1990, 79-80 o.).

A Pálné Kovács Ilona által tett fenti megállapítás és az eddigi elméleti eredményeink tehát egy út felé vezetnek el bennünket: összehasonlító kutatások csak komplex módon végezhetőek el. Az elemzés egységei, az esetek, a választott elemzési módszerek és az elemzés tartalma egyaránt kulcsfontosságú tényezők az öszszehasonlítás sikere szempontjából.

A nehéz tudományelméleti kérdésre, miszerint mi értelme van olyan teljesen eltérő szociokulturális, gazdasági, politika és még számtalan értelemben vett egyedi egységek összehasonlításának, mint az országok, illetve azok régiói, már sokkal nehezebben kaphatunk választ. A regionális tudomány idézett képviselöi kitértek az azonosságok és különbözőségek azonosításának fontosságára, azonban a kialakult szakmai konszenzus ebben az esetben mégis főként a kutatói ,józanészre”, illetve innovációs képességre látszik alapozódni. Erre a felvetésre az esettanulmány-készítés módszere adhat bizonyosfajta iránymutatást. 


\subsection{REGIONÁLIS ÖSSZEHASONLÍTÁSOK A MAGYAR RÉGIÓK LAKOSSÁGA ESETÉBEN}

Jelen fejezetrész célja egyfelől a regionális összehasonlítások módszertani hátterének a körbejárása. Másfelől azonban célként fogalmazhatjuk meg azt is, hogy azonosítani kívánjuk azokat az ország-specifikus tényezőket, amelyek a magyar régiók esetében nehezíthetik a regionális összehasonlítást. Kovách és Nagy Kalamász írásában kitér erre a problémára:

„Nehezen vizsgálható és a jelentös eredményeket felhalmozó regionális és egyéb kutatások ellenére sem írható le pontosan, hogyan hat egymásra a település-és a társadalomszerkezet, és sajátosságaik hogyan határozzák meg egymást." (Kovách-Nagy Kalamász 2006, 161.o.)

A következőkben néhány pontban szót ejtünk azokról a nehézségekről, amelyek megnehezíthetik a különböző régiók közötti empirikus összehasonlítást, illetve befolyásolhatják annak megbízhatóságát.

\subsubsection{A területi hatalmi koncentráció kérdésköre}

Kovách Imre és Nagy Kalamász Ildikó a magyar területi rendszer hatalmi koncentrációja szempontjából két jellemzőt emel ki, mely hatással van a helyi társadalmakra: egyfelől a települési önkormányzatok magas számát, illetve a decentralizált területi irányításban a koncentráció hiányát, a középszintü önkormányzatok alacsony dominanciáját. A korábbi állami dominanciával szemben a rendszerváltás után megnőtt a települések és a térségek önállósága, de ez az önállósodás a területi középszint esetében elmaradt.

A térségek arculatát egyfelől a szabadon választott képviselet és az általa elvégzendő decentralizált feladatok határozzák meg, ám e fölött a szint fölött még mindig erős a centrális állam dominanciája, mivel az önkormányzatok költségvetésének nagy része központi forrásból származik (Kovách-Nagy Kalamász 2006).

Pálné Kovács Ilona a helyi politika célját pragmatikus célként jelöli meg, mely fơként a település vagy térség müködtetése, kevésbé a hatalom megszerzése vagy megtartása. Ezáltal a „helyi” óhatatlanul szembekerül a „nagypolitika” kizárólagos hataloméhségével. A függés a központi kormányzattól éppen ezért minden helyi 
és területi önkormányzat esetében erős, és komoly kihatással lehet a müködésre. A megyék „lebegése” pedig egyenesen bizonytalanságot teremt a középszintü önkormányzatisággal kapcsolatban (Pálné Kovács 2008).

Az egyes régiók tehát közigazgatási és politikai szempontból egymáshoz hasonló helyzetben vannak. Ám ez a hasonló helyzet nem egyforma eredményeket hoz az egyes régiók számára: a fejlettebb Nyugat-Dunántúl és Közép-Dunántúl régióknak jobb eszközrendszerrel kell kevesebb társadalmi problémával megküzdeniük, mint a rosszabb eszközrendszerrel és sokkal több megoldandó társadalmi problémával rendelkező Észak-Magyarországi és Észak-Alföldi régióknak. A területi középszint bizonytalansága tehát gátként áll szemben a régiók közti forrásallokáció differenciálása szempontjából.

\subsubsection{Gazdasági fejlettségbeli különbség}

Horváth Gyula írja, hogy Magyarországon a területi különbségek hatalmas mértékben növekszenek. Míg a Közép-Magyarországi régió teljesítménye egyre növekszik, a perifériális és rurális régiók a folyamatos leszakadás útján mozognak. A regionális gazdasági különbségek hatalmasak. A vidéki megyei jogú városok, ahol fiatal, magasan képzett, nyelveket beszélő szakértelmiségiek hagyják el az egyetemek padjait, nem képesek vonzóvá válni ezen képzett réteg számára, nem képesek helyben tartani öket. Az európai regionális rangsorban a magyar régiók közül fejlettség szempontjából kizárólag a Közép-Magyarországi régió került be a második harmadba. A második legfejlettebb régió, a Nyugat-Dunántúl a harmadik harmad legtetején áll. A többi régió kizárólag kelet-európai térségekkel körülvéve a harmadik harmad közepén található meg (Horváth 2005).

\subsubsection{Töredezett településszerkezet}

Magyarország megyéiben, régióiban komoly különbségeket találhatunk a településszerkezetben. Míg az alföldi térségekben alacsonyabb településszám jellemzö, a Dunántúlon magasabb. Az átlagos településméretben is találunk különbségeket.

A Dél-Dunántúl 654 településnek több mint fele 500 fős lélekszám alatti aprófalu, az átlagos települési népességszám is alacsonyabb, mint az országos átlag (Arany-Gyurokné dr. Bódi 2004). 
Ez a példa jól illusztrálja, hogy a regionális összehasonlítások elvégzésekor érdemes tekintettel lennünk a vizsgált régiók településszerkezetére. Továbbá ha van lehetőségünk, a jobb reprezentáció érdekében érdemes különböző mintavételi technikákat használni a több, illetve kevesebb és eltérő méretü településsel rendelkező térségekben.

\subsubsection{Aszinkronitás a településstruktúra és a társadalom átalaku- lása között}

A rendszerváltás után a településstruktúra lassabban alakult át, mint a társadalom. A jelenkori magyar társadalom térszerkezetének jellemzőivel kapcsolatban elmondható, hogy az országban a huszadik század utolsó harmadában újabb modernizációs fordulat következett be. Ez a fordulat jelentősen megváltoztatta a városok gazdasági és társadalmi berendezkedését, illetve megváltoztatta a vidéki és városi társadalmak kapcsolatát. Európa minden országában eltủnt a parasztság mint értelmezhető társadalmi csoport. A parasztság eltűnésével együtt járt a nagyobb vidéki tömegek városokba vagy városi agglomerációkba áramlása, amit az érintett területeken egyféle „rurális exodusként” tartanak számon. Nyugat-Európában már lezajlott a deruralizáció, azaz a vidéki népesség számának és arányának nagymértékü csökkenése. Kelet-Európában a hibás szerkezetátalakítás miatt a mezőgazdasági termelés visszaesése tapasztalható, ám ezt nem követte a mezőgazdasági népesség számának a csökkenése (Kovách-Nagy Kalamász 2006).

A nem városi települések népessége minden közép-európai országban növekedett, de legalább nem csökkent a kilencvenes évek közepétől. A közép-kelet-európai régióra jellemző kistelepülési életkörülmények csak ritka esetben nevezhetőek városiasnak, még ha a település városi rangú is. Ezért Kovách és Nagy Kalamász véleménye szerint a vidéki népesség aránya a közép-kelet-európai országokban inkább közel van az ötven százalékhoz. A térség fontos problémája tehát az, hogyan lehet úgy bevezetni a modernizációt, hogy az ne csak a városközpontokba koncentrálódjon, hanem a kisvárosokra és falvakra is legyen hatása. A szerzők vélemény szerint sokszázezres tömegek úgy záródtak be a falvakba és a kisebb városokba, hogy elveszítették kitörési pontjaikat és integrációs lehetőségeiket. A korábbi átjárhatóság a vidéki és városi életforma között napjainkra megszünni látszik. A falusi underclass kialakulása ezen néptömegek városba áramlásáig komoly társadalmi és térszerkezeti problémákat okozhat (Kovách-Nagy Kalamász 
2006). E témát Németh Zsolt is feldolgozta az 1990-es népszámlálási adatokat véve kiinduló állapotnak a térbeli társadalomszerkezetet azóta is meghatározó tendenciák bemutatásakor. Az államszocializmusban kialakult fejlesztéspolitika a városokat, közülük is a fővárost és a megyeszékhelyeket célozta, így teremtve meg a vidéki településekhez képest magasabb szintủ életszínvonalat és a szolgáltatásokhoz való hozzáférés célzottan egyenlötlen körülményeit, ami a térbeli társadalomszerkezetet is alapvetően befolyásolta a nagyváros-vidék relációban. Mindez a szocializmus teljes foglalkoztatottságot célzó körülményei között civilizatórikus különbségeket eredményezett, de ezen túlmenően már az 1990-es népszámlálás adatai alapján is kirajzolódott, hogy a legelesettebb társadalmi csoportok a kistelepüléseken koncentrálódtak. Az adatok arra is rávilágítottak, hogy minél nagyobb településen élt valaki 1990-ben, már ekkor is nagyobb esélye volt arra, hogy kereső tevékenységet végezhessen, míg a kistelepüléseken élők jól látható hátránya is megmutatkozott. A nagyobb településeken koncentrálódott továbbá a magasabb végzettségü és szellemi foglalkozású lakosok zöme is. E területi különbségeket a rendszerváltozást követő társadalmi-gazdasági folyamatok egyértelmúen megnövelték, amit tetézett az a jelenség is, hogy a városokból a falusi gyökerú népesség egy része a 90-es években visszaáramlott a kistelepülésekre, a térbeli társadalomszerkezet alakulásának leglényegesebb folyamatát okozva (Németh, 2011).

\subsubsection{A cigány népesség regionális megoszlása}

A cigányság magyarországi lélekszámával kapcsolatban pontos számadatokkal több konceptuális és módszertani probléma miatt nem rendelkezünk, így nem ismerjük pontos területi megoszlásukat sem. Azonban rendelkezünk pontosnak tekinthető szakértő becslésekkel, illetve vannak információink a cigány népesség koncentrációját illetően egyes térségekben. Az adatok semmiképpen nem tekinthetőek frissnek, ám állításunk megfogalmazásakor a vizsgált kérdés időben csak hosszabb távon változó jellege miatt alapozhatunk rájuk. Illetve pontos számadatokra nem, csupán az aránytalanságok felismerésére van szükség ahhoz, hogy kimondhassuk, a cigány népesség felül- vagy alulreprezentált egy térségben.

A magyarországi cigányság 18,5\%-a él a fővárosban, 27,7\%-a él ÉszakMagyarországon, illetve 23,4\% a Dunántúlon, főleg a déli- és középső részeken (Kocsis-Kovács 2001). 
A fenti adatok alapján tehát egyértelműnek tetszik, hogy regionális összehasonlítások végzésekor figyelembe kell venni a cigány népesség felül-, illetve alulreprezentáltságát.

\subsection{MODELL AZ ADATOK ÖSSZEHASONLÍTHATÓSÁGÁNAK (INVARIANCIÁJÁNAK) TESZTELÉSÉRE}

A fentiek alapján szükségesnek véltünk egy megerősítést, miszerint a komplex megközelítésű regionális összehasonlítás, amelyet végrehajtani tervezünk megállja-e majd a helyét. Azt tervezzük tesztelni, hogy az általánosított bizalom hogyan változik a magyar régiókban, mást vagy ugyanazt jelenti-e a különböző térségekben, azaz tapasztalható-e mérési invariancia. Felállítottunk egy modellt, amelynek segítségével a mérés sikerességét és a változókat, mint a társadalmi tőke koncepció jellemző elemeit kívántuk górcső alá venni, regionális összehasonlításban.

Ennek érdekében három szinten invariancia vizsgálatot végeztünk egy a magyar régiók válaszadóit külön mintaként kezelö többcsoportos mérési modell segítségével. A mérési modell célja, hogy gondolatainkat segítsen operacionalizálni, elméleteinket tesztelni. A módszer lényegében a faktorelemzés, a regresszió-elemzés és az útelemzés keveréke, mely egyben lehetőséget biztosít a különböző említett módszerek előnyeinek kihasználására (Füstös-Kovács et al. 2004; SchumackerLomax 2004). A modellben a mért változók segítségével próbáltuk meg azonosítani az „Általánosított Bizalom”13 látens változó meglétét. Az alapmodellben a hibatagok regressziós értékét 1-ben fixáltuk, és eddigi vizsgálódásaink alapján a modell megfelelő identifikálása érdekében ezt tettük ezt a 'ppltrst' és 'pplfair' változóval is. Így elértük a megfelelő, nullánál nagyon modell-szabadságokat, és a modell identifikáltnak tekinthetö.

A modell segítségével kívántuk továbbá megállapítani, hogy az általunk meghatározott csoportok - azaz jelen esetben a magyar régiók adatai - összehasonlíthatóak-e, és ha igen, milyen mértékben. Az összehasonlíthatóság mértékét az elért invarianciatípus határozza meg. Az invariancia vizsgálata segít nekünk megállapítani, hogy a különböző mért változók ugyanazokat a látens változókat adják-e ki a vizsgálati csoportok összességében. Azt teszteltük, hogy ugyanazt az elméletet

13 a) Mért változók: (1) ppltrst: a legtöbb emberben meg lehet bízni; (2) pplfair: a legtöbb ember tisztességes; (3) pplhlp: a legtöbb ember segítőkész. 
(látens változót, faktort) mértük-e meg a különböző csoportokban, ugyanazon változók segítségével. Az invariancia első szintje az ún. konfigurális invariancia. Ezen típus létrejöttének feltétele csupán annyi, hogy az egyes mért változók ugyanazt a látens változót mérjék minden csoportban (Füstös-Kovács et al. 2004; Chen 2007). Ebben az esetben a faktor-súlyok nem kell, hogy megegyezzenek, és ha a faktorsúlyokban különbséget tapasztalunk, a konfigurációs invariancia továbbra is fennáll. Ilyen esetekben azt mondhatjuk, hogy hasonló, de nem azonos koncepciókat mértünk az egyes csoportok esetében.

Az invariancia második szintje a mért változók által meghatározott látens faktorok faktorsúlyának mértékével foglalkozik. Ahhoz, hogy azt mondhassuk, két csoport metrikus értelemben invariáns, a faktorsúlyoknak meg kell egyezniük. A faktorsúly a látens változó lineáris kapcsolatainak mértékét jelzi a mért változókkal és más hozzákapcsolt itemekkel. Ez a fajta invariancia kívánatos ahhoz, hogy korrelációs és regressziós kapcsolatokat vizsgálhassunk a különböző csoportok változóinak összehasonlításával. Ezt az invarianciaszintet nevezzük metrikus invarianciának, és megléte lehetővé teszi az adatok korrelációinak összehasonlítását (Byrne 2004; Chen 2007).

Az invariancia harmadik szintjét skálás invarianciának nevezzük, mely elöfeltétel a vizsgált csoportok átlagainak összehasonlíthatóságához. Az invariancia ezen típusát a szakasz-metszéspontok egyenlősége esetén feltételezzük. Ez a legmagasabb szintű invariancia, példaként az hozható fel a meglétére, hogy például egyes országok kulturálisan közelebb állnak egymáshoz, és csoportot alkotnak és ezáltal elválnak más országoktól és ország csoportoktól. Ez a kulturális közönség lehetővé tesz összehasonlításokat a csoport tag országok között, ami viszont más országokkal a teljesen eltérő kulturális háttér és jelentéstartam miatt teljesen elképzelhetetlen (Davidov 2008).

Barbara M. Byrne beszél továbbá parciális invarianciáról, amikor nem az egész modell átlagai hasonlíthatóak össze, csupán azon részeké, amelyeket külön leteszteltünk ebből a szempontból (Byrne 2001; Byrne 2004).

Első lépésként az általunk kialakított, általánosított bizalmat leképező mérési modell segítségével végezzük el a hét magyar régión a konfigurális invariancia meglétének tesztelését. Elgondolásunk szerint feltételezhetjük a konfigurális invarianciát, hiszen a magyar régiók közötti különbségek nem elemi mértékủek, csupán színes diverzitás tapasztalható, nem gyökeresen más mintázatok és trendek az egyes térségekben. A modell AMOS programban felrajzolt sematikus vázát a 10. ábra mutatja be. 


\section{7. ábra - Konfirmációs faktorelemzés mérési modell az „Általánosított Biza-} lom" látens változóval kapcsolatban (Unconstrained, beállitások nélküli, a konfigurális invariancia teszteléséhez)

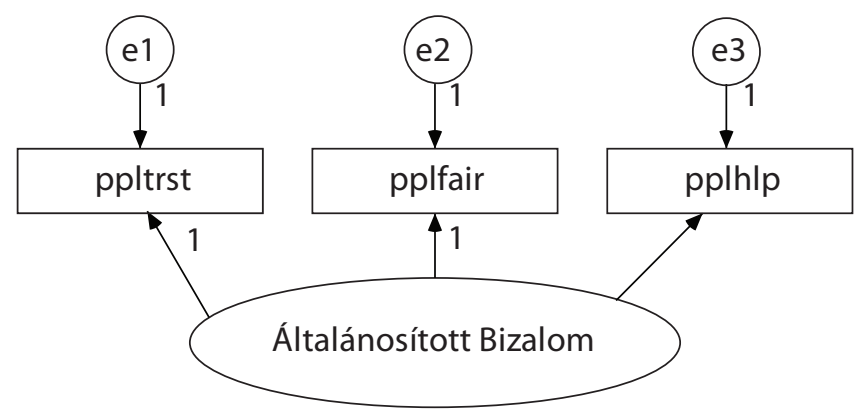

$D F=7 C h i-S q=7,73 P=0,357 C M I N / D F=1,105 \quad C F I=0,999 \quad$ RMSEA=0,008 PCLOSE=0,999 Forrás: saját szerkesztés AMOS programmal, ESS 3. hullámadatok alapján

A modell magyarázata:

a) Mért változók: (1) ppltrst: a legtöbb emberben meg lehet bízni; (2) pplfair: a legtöbb ember tisztességes; (3) pplhlp: a legtöbb ember segítőkész.

b) Hibatagok: e1; e2; e3.

c) Látens, nem mért változó: Általánosított Bizalom.

d) A nyilak az oksági kapcsolat irányát jelzik.

A modell tesztelése alapján arra a következtetésre jutunk, hogy a modell identifikált, illeszkedése megfelelő. A CFI, RMSEA és PCLOSE értékek azt jelzik, hogy a modellünk megfelelö, ezért elgondolásunk, miszerint a magyar régiók adatainak alapmodellel történő összehasonlításakor konfigurális invariancia lesz tapasztalható, igazolódott.

A következő két lépésben a metrikus és skálás invariancia meglétét fogjuk tesztelni. Ennek érdekében létrehoztunk egy olyan modellt, melyben minden egyes elemet paraméterekkel láttunk el, és visszavettük a 'pplfair' változó regressziós értékét a program által számolandó értékek közé, mivel ezen paraméter fixálása nélkül is megfelelő a modell identifikáltsága. Az 11-es ábra tartalmazza a paraméterekkel ellátott (constrained) modellt, melyet fel fogunk használni a metrikus invariancia tesztelésére a mérési súlyok egyenlőnek tételezése segítségével, illetve 
a skálás invariancia tesztelésére, mely esetben a mérési metszéspontokat fogjuk egyenlőnek tekinteni.

\section{8. ábra-Paraméterekkel ellátott (Constrained) modell a metrikus és skaláris invariancia teszteléséhez.}

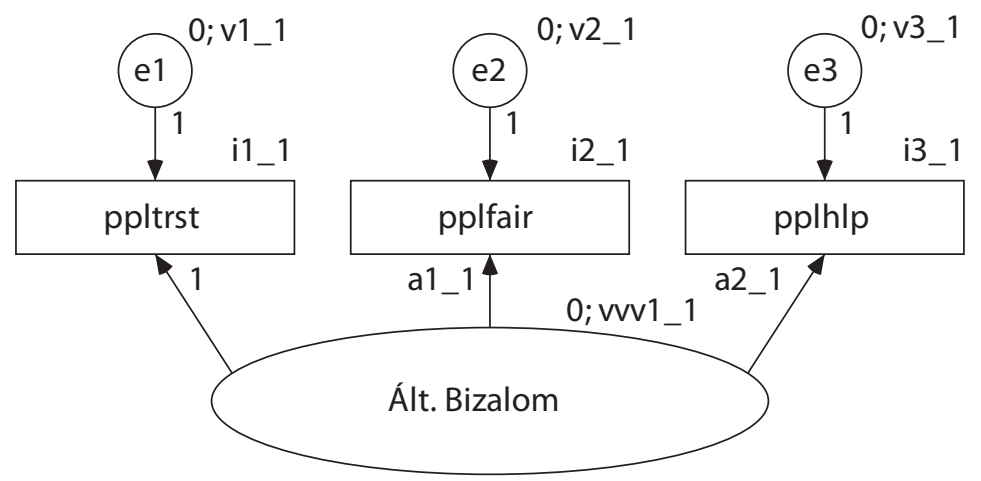

Forrás: saját szerkesztés AMOS programmal, ESS 3. hullámadatok alapján

\subsubsection{A mérési súlyokat egyenlőnek tételező (measurement weights) modell $^{14}$}

A modellt az alábbi eredményekkel futtattuk le: $\mathrm{DF}=12$ Chi-Sq $=8,850 \mathrm{P}=0,716$ $\mathrm{CMIN} / \mathrm{DF}=0,738 \quad \mathrm{CFI}=1 \quad \mathrm{RMSEA}=0,000 \quad \mathrm{PCLOSE}=1,00$. Ennek alapján elmondható, hogy a szabadságfok megfelelö, a modell illeszkedik. A CMIN/DF érték a hüvelykujj-szabály által meghatározott 1-es minimum értéknél kisebb, de még elfogadható. A CFI, RMSEA és PCLOSE értékek tökéletes illeszkedésről árulkodnak. A modell a fentiek alapján egyértelmüen demonstrálja, hogy beszélhetünk mérési invarianciáról a magyar régiók adatainak összehasonlítása esetében. Az egyes térségekben felvett változók értékei korreláltathatóak egymással, regressziós vizsgálódások végezhetőek az általánosított bizalom tekintetében. Mérési invariancia áll fenn a térségek adatainak tekintetében, amely azt mutatja, hogy hasonló módon gondolkodnak a válaszadók a vizsgált általánosított bizalomelmélettel kapcsolatban.

$\begin{aligned} & \mathrm{a} 1 \_1=\mathrm{a} 1 \_2=\mathrm{a} 1 \_3=\mathrm{a} 1 \_4=\mathrm{a} 1 \_5=\mathrm{a} 1 \_6=\mathrm{a} 1 \_7 \\ & \mathrm{a} 2 \_1=\mathrm{a} 2 \_2=\mathrm{a} 2 \_3=\mathrm{a} 2 \_4=\mathrm{a} 2 \_5=\mathrm{a} 2 \_6=\mathrm{a} 2 \_7\end{aligned}$ 


\subsubsection{A mérési metszéspontokat egyenlőnek tételező (measure- ment intercepts) modell ${ }^{15}$}

A modellt az alábbi eredményekkel került futtattuk le: $\mathrm{DF}=18$ Chi-Sq=38,305 $\mathrm{P}=0,004 \mathrm{CMIN} / \mathrm{DF}=2,128 \quad \mathrm{CFI}=0,983 \quad \mathrm{RMSEA}=0,027 \quad \mathrm{PCLOSE}=0,999$. Az első megállapítás az, hogy a modellel nem illeszkedik, mivel a P érték 0,05 alatti. Ennek fényében a többi paraméter értelmezése nem lehetséges. Arra az eredményre jutunk, hogy jelen m odellnél skálás invarianciáról nem beszélhetünk a magyar régiók adatai esetében. Ez az eredmény azt sugallja, hogy a magyar régiók általánosított bizalommal kapcsolatos átlagai nem hasonlíthatóak össze, hiszen a látens konstrukció minden egyes térségben mást jelent, vagy legalábbis nem található egységes, skálás értelemben invariáns egységes jelentéstartam. Vizsgálódásaink ezen eredményét feltétlenül evidenciában tartjuk, hiszen ez a magyar régiók különbözőségére, egyedi arculatára utal az általánosított bizalom szempontjából. Azonban nem vethetjük el azt a feltételezést sem, hogy eredményeinket befolyásolta az egyes térségekben felvett alacsony kérdöív elemszám is.

\subsection{TANULSÁGOK}

Jelen fejezet tapasztalatai alapján elmondható, hogy míg a nemzetközi összehasonlító lakossági felmérések esetében rendelkezünk kialakult módszertani hagyománnyal, melyet a kutatók már képzésük során elsajátítanak (Pászka 2008), ilyen egyértelmű módszertani készlet a regionális felmérések és összehasonlítások esetében nem áll rendelkezésre. Áttekintettük és regionális összehasonlítás szempontjából próbáltunk reflektálni az összehasonlítás módszereire. Tanulságként a tér, mint kiemelt elemzési alapkategória került előtérbe. A regionális összehasonlítások esetében az elemzések fó motivációja nem az elemzési tematika, hanem az összehasonlítás alapját adó térkategória, a régió.

A fenti tapasztalat mellett fontos továbbá, hogy a magyar regionális lakossági felmérések esetében célszerú figyelembe venni néhány regionális egyenlötlenséget, amelyekkel kapcsolatban már rendelkezünk empirikus kutatási tapasztalatokkal, így azokat számba tudtuk venni.

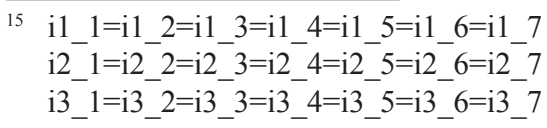


A másodelemzések céljára használt két nemzetközi empirikus kutatás adatbázisai módszertani szempontból teljesítik az alapvető kívánalmakat: mindkét kutatás az európai NUTS 2-es területi egységek, azaz a régiók szintjén reprezentatív. Ennek alapján el lehet végezni a régiók közötti empirikus összehasonlításokat, melynek csupán a minta elemszám adhatja korlátját. Az Eurobarometer kérdőív különböző hullámai Magyarország szintjén 1000 körüli megkérdezett válaszait tartalmazzák, míg az EUTE/ESS kérdőív harmadik hulláma 1518 választ tartalmaz. A fenti mintanagyságok a régiók esetében a vizsgált a régiók lakosságszáma szerinti arányában oszlanak meg.

A mérési invariancia tesztelésével azt kívántuk megvizsgálni, hogy milyen mértékben jelentik ugyanazt a vizsgált elméleti konstrukciók a különböző területi egységek, jelen esetben a magyar régiók szintjén. Az invariancia vizsgálat nem tudta kimutatni a skálás invariancia meglétét, amely azt jelenti, hogy nem azonos a módszertani példaként vizsgált ,általánosított bizalom” koncepció jelentése a különböző térségekben. Ez az eredmény heterogenitásra utal, speciális regionális jelentéstartalmak meglétére utal, továbbá arra, hogy a régiók közötti eltéréseket érdemes vizsgálni. A skálás invariancia hiányát nyugtáztuk, és statisztikai elemzéseinkben igyekszünk azt figyelembe venni, mindamellett, hogy további regionális különbségeket igyekszünk feltárni. 


\section{A TÁRSADALMI TŐKE VIZSGÁLATA A MAGYAR RÉGIÓKBAN}

A kutatás elméleti részében részletesen bemutattuk, hogy milyen sokdimenziós és sokrétü teória a társadalmi tőke elmélet. Az empirikus kutatások készítői által általánosan tapasztalt jelenség az ezen sokdimenziós fogalom operacionalizálására tett próbálkozások nehézsége. A legjobb elméleti szerzők is csupán „hozott” anyagból dolgoznak a kvantitatív megközelítések esetében, azaz meglévő kutatások másodelemzéseit végzik el (Vö: Putnam 2000). Saját kutatások készítése általában sokkal nehezebben valósítható meg, és lényegesen korlátozottabb hatáskörrel (Vö: Putnam 1993). Ennek egyik oka, hogy egy kizárólag a társadalmi tőke mérésére kialakított és a kellő összehasonlításokat lehetővé tevő kutatás igen költséges. A társadalmi tőke egyes elemeinek a kvantitatív mérés számára történő operacionalizálása is nehézségekbe ütközhet, és némely esetekben ütközik is. További nehézséget okoz a kulturális különbségeknek megfelelő konceptualizálás és operacionalizálás a globális világ eltérő kulturális hátterü és nyelvü társadalmai esetében.

E nehézségeket felismerve és követve a legtöbb kutató által alkalmazott elemzési gyakorlatot, a társadalmi tőke bonyolult koncepciójából csupán két elemet operacionalizáltunk az Európai Társadalmak Összehasonlító vizsgálata (ESS) kérdőíves kutatás harmadik hullámának adatai alapján, mely adatok 2006-ban kerültek felvételre. A vizsgálat Magyarország tekintetében a NUTS 2-es (regionális) szinten reprezentatív. A regionális reprezentativitás mellett a felmérés országos reprezentativitást és összességében 1500-as elemszámot biztosít.

A két vizsgált elméleti dimenzió az (1) általánositott bizalom és az (2) intézményekbe vetett bizalom dimenziói. Igyekeztünk a magyar adatbázison regionális összehasonlításokat végezni, ahol az elemszámok lehetővé tették azt, természetesen többváltozós statisztikai eljárások segítségével. Az elemszámok regionális megoszlását az 5. táblázat tartalmazza. 


\section{5. tábla-Az ESS/EUTE harmadik hullám elemszámok regionális megoszlása}

\begin{tabular}{|l|l|}
\hline Régió & $\mathrm{N}$ \\
\hline Központi & 338 \\
\hline Közép-Dunántúl & 203 \\
\hline Nyugat-Dunántúl & 170 \\
\hline Dél-Dunántúl & 171 \\
\hline Észak-Magyarország & 193 \\
\hline Észak-Alföld & 231 \\
\hline Dél-Alföld & 212 \\
\hline Összesen & 1518 \\
\hline
\end{tabular}

\section{1 ÁLTALÁNOSÍTOTT SZEMÉLYKÖZI BIZALOM}

Az első operacionalizált koncepció az általánosított személyközi bizalom elmélete. A koncepció lényege, hogy megvizsgáljuk, az emberek mennyire bíznak a társadalomban, a többi emberben, illetve mennyire számítanak mások önzetlen segítségére vagy negatív cselekedeteire. A személyközi bizalom magas szintjének megléte nélkül nem képzelhető el a civil társadalom zökkenőmentes müködése, az emberek közötti fennakadásmentes kooperáció (Seligman 1997). A bizalom e formája garantálja, hogy az emberek prekoncepció-mentesen hajlandóak szóba állni egymással, hajlandóak rövidebb-hosszabb távú együttmúködéseket kialakítani, illetve közösen fellépni az őket érintő és érdeklő ügyekben. Ugyanez a bizalomtípus gátolja meg azt, hogy egyes segítségre szoruló embereket embertársaik teljesen magukra hagyjanak. A bizalom e formája társas interakciók által termelődik, illetve csökken a társadalomban ( Govier 1998; Rus-Iglic 2005.)

Az általánosított/személyközi bizalom kifejezetten bonyolult koncepció. Mérése igencsak nehézkesnek tekinthető, és operacionalizálása nehéz feladat elé állítja a kutatókat. Az általunk felhasznált ESS kérdőívekben az általánosított bizalom szintjének mérését három kérdés segítségével végzik: (1) A legtöbb emberben meg lehet bizni, vagy inkább azt, hogy nem lehetünk elég óvatosak az emberi kapcsolatokban? (2) Gondolja, hogy a legtöbb ember megpróbálná kihasználni Önt, ha alkalma nyílna rá, vagy igyekeznének tisztességesek lenni? (3) Ön szerint az emberek csak magukkal törödnek, vagy általában segitókészek? A három 
kérdés körbejárja társadalmi életünk legfontosabb dimenzióját: azt, hogy képesek vagyunk-e másokban megbízni, mások szándékairól jót feltételezni, illetve más emberek segítségére számítani. Az eredeti elmélet mérése ennél természetesen lényegesen bonyolultabb módon is végrehajtható, ám ez a fajta operacionalizáció az általánosan elterjedt, mondhatni letisztult forma.

Egyes kutatók az általános bizalom koncepcióját nagymértékben azonosítják a társadalmi tőke koncepciójával, ám nem az egyéni szinten birtokolható társadalmi tőke fogalmával, hanem a közösségi szinten müködő civil, bevonódáshoz szükséges, network által birtokolt változattal (Cox 1995; Seligman 1997; Putnam 2000). Jelen munka szempontjából is elmondható, hogy a három kérdés, melyet az általánosított bizalommal kapcsolatban feltesznek, jól modellezi a társadalmi tőke megjelenési formáit és müködési lehetőségeit a vizsgált régiókban. Ahol az emberek képesek megbízni a többi emberben, nem feltételeznek rosszat róluk - sőt esetleg azzal az érzéssel viseltetnek embertársaik irányában, hogy tölük szorult helyzetükben segítségre számíthatnak -, ott képzelhető csak el, hogy igazán jól müködjön a társadalmi tőke. A bizalom, a szolidaritás és az azonnali viszonzás nélküli reciprocitás, a társadalmi részvétel megköveteli a barátságos, magas általánosított bizalommal átitatott társadalmi környezetet.

Elemzésemben először régiónként vizsgálom meg, hogy a válaszadók mennyire gondolják azt, hogy a legtöbb ember megbízható. A 9. ábra adataiból kitünik, hogy a legnagyobb átlageredményt $(4,6)$ elérve a központi régió lakosai gondolják azt, hogy embertársaik többsége megbízható. Ez egy komoly kérdést vet fel: mivel a központi régió lakosságának nagy többsége budapesti, és egy nagyvárosban az általánosított bizalom szintje általában nem túl magas, ebben az esetben érdekes jelenséggel állunk szemben. A központi régiót követi a Nyugat-Dunántúl $(4,57)$ és Közép-Dunántúl $(4,5)$ szintén magas általánosított bizalom értékekkel. Ezen három térség átlagértékei több mint két tizedponttal magasabbak, mint az országos értékek, és a többi térség átlagértéke kivétel nélkül az országos átlag alatt van. Ez az eloszlás arra enged következtetni, hogy a gazdasági sikeresség és az általánosított bizalom között direkt összefüggés lelhető fel, hiszen a három legfejlettebb magyar térség - GDP sorrendjüknek megfelelően - követi egymást általánosított bizalom szempontjából is. 


\section{9. ábra-Általánosított bizalom: A legtöbb ember megbízható (1-10 skála, átlagértékek)}

\section{A legtöbb ember megbízható...}

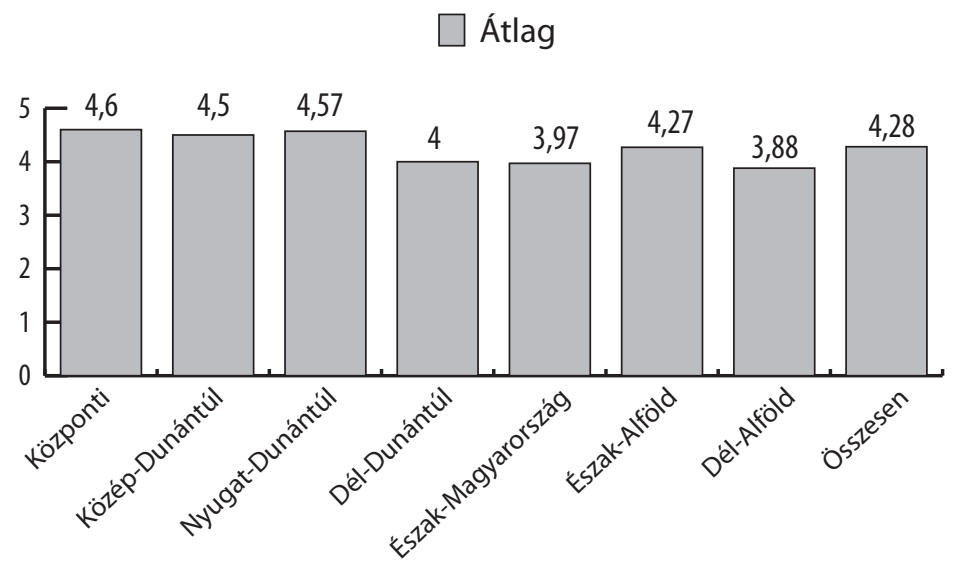

Az Észak-Alföld átlaga $(4,27)$ szinte teljes egészében leképezi az országos átlagot. Innentől komoly esést tapasztalhatunk: a Dél-Dunántúl (4) átlaga több mint két tizeddel marad el. Észak-Magyarország $(3,97)$ és a Dél-Alföld $(3,88)$ a két utolsó helyezett a közbizalom listán.

Mivel a fenti elemzésbe az általánosított bizalmat mérő változók közül csupán egyet tudtunk bevonni, a kapott adatok nem reflektálnak a koncepció egészére vonatkozóan. Ezért főkomponens elemzést készítettünk, melynek keretében a három változó információtartalmát egy változóba tömörítettük. Mielött ezt megtettük, skálatesztelés statisztikával ellenőriztük, hogy a változók egy, illetve többdimenziós jelleget mutatnak-e. A Cronbach Alfa statisztika eredménye szerint a változók egydimenziós koncepció elemeiként funkcionálnak, a statisztika értéke 0,772, amely azt jelzi, hogy az általánosított bizalom mérésére használt, három változóból álló skála megbízható.

A fökomponens kiválóan képezte $1 \mathrm{e}^{16}$ a három változót. A kapott fökomponens értékeket elmentettük, és az egyes régiókat e fơkomponens értékek alapján hasonlítottuk össze (vö.: Utasi 2008). E pontszámok standardizált formában jelennek

16 Több mint 68.7\% megőrzött információtartalom az eredeti változókból. 
meg, abszolút értéküknek jelentése nincs, csupán egymáshoz viszonyított különbségeik jelzik az általánosított bizalom különbségeit a térségek összehasonlításában. A magasabb fókomponens értékek magasabb általánosított bizalmat, az alacsonyabbak alacsonyabbat jelentenek. Az eredményeket a 10. ábra tartalmazza.

\section{0. ábra-Általánosittott bizalom: Fökomponens pontszámok regionális összehasonlitása (standardizált)}

Fökomponens pontszám átlag

Átlag

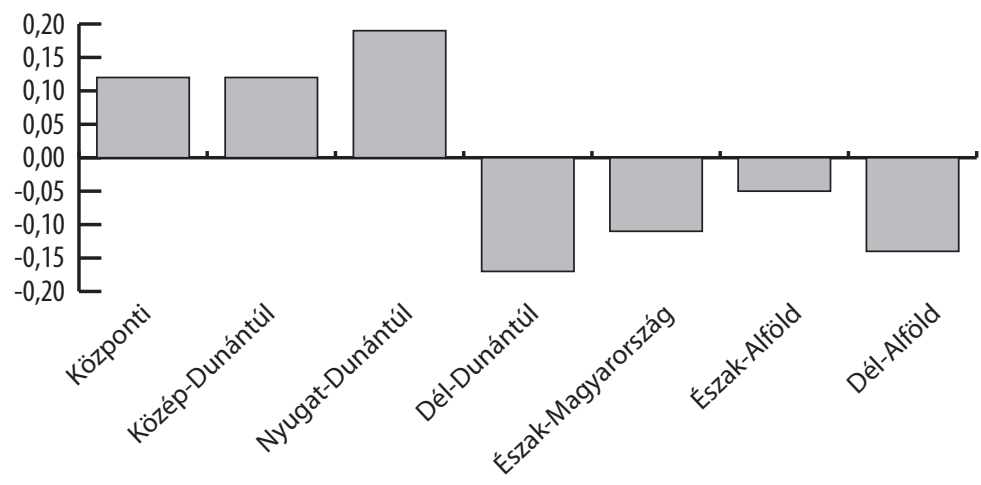

A főkomponens pontszámok összehasonlítása alapján látható, hogy ha mind a három általánosított bizalmat mérő változót számításba vesszük, a magyar régiók közül a legmagasabb a Nyugat-Dunántúl értéke, melyet a központi régió és a Közép-Dunántúl követ. Ez a három, gazdasági szempontból kifejezetten fejlett térség az általánosított bizalom mértékének szempontjából is a magyar régiók listájának az élén áll. Tudható és e munka keretein belül is érveltünk már amellett, hogy a jó gazdasági eredmények elérésének feltétele a bizalom másokban, a kooperáció elengedhetetlen feltétele szintén a közbizalom, az azonnali viszonzás nélküli szolgáltatások megjelenésének pedig hasonlóképpen kedvez a magasabb bizalmi szint. E három térség esetében ez adott, és a kutatás eredményei alátámasztják, hogy valóban múködik is. A hátrányosabb helyzetben lévő magyar régiókhoz képest ez a három térség evvel a társadalmi adottságával is kitünik, és előnybe kerül. 
A negyedik a listán az Észak-Alföld, amely ebben az esetben is köztes pozíciót tölt be, nem sorolható egyértelmúen egyik csoporthoz sem: nem tartozik a magas általánosított bizalommal rendelkezőkhöz, sem az alacsonyakhoz. Alacsony az általánosított bizalom szintje Észak-Magyarországon, ezt követi a Dél-Alföld és a Dél-Dunántúl. Ez a három régió ezen alacsony érték hasonló mértéke alapján egy csoportba sorolható: e térségekről elmondható, hogy az emberek egymásban kevésbé bíznak, nem számítanak mások jó szándékára és segítségére. A társadalmi tőke szempontjából mindenképpen hátrányban vannak a magas általánosított bizalomszinttel rendelkező térségekhez képest, és ez kihat mind a társadalmi, civil, politikai és természetesen a gazdasági életükre is.

\subsection{INTÉZMÉNYEKBE VETETT BIZALOM}

Az intézményekbe vetett bizalom alapja az egyes személyek nem egymással, hanem intézményekkel folytatott interakciója (Rus-Iglic 2005). Az intézmények rendelkeznek azzal a képességgel, hogy bizalmat birtokoljanak, és az általuk birtokolt általánosított bizalmat átruházzák más intézményekre, illetve személyekre. Ez a fajta bizalom-koncentrálás és általánosítás azért fontos, hogy az intézmények képesek legyenek áthidalni például a gyenge társadalmi kapcsolatok, illetve az alacsony általánosított/interperszonális bizalomszint által támasztott akadályokat (Granovetter 1973).

Az ESS kérdőívben 7 változó elem méri az intézményekbe vetett bizalmat, az alábbi formában: „, Kérem mondja meg, hogy Ön személy szerint mennyire bizik a következö intézményekben:"

(1) a magyar Országgyülésben? (trstprl)

(2) a magyar jogrendszerben? (trstlgl)

(3) a rendörségben? (trstplc)

(4) a politikusokban? (trstplt)

(5) a politikai pártokban? (trstprt)

(6) az Európai Parlamentben? (trstep)

(7) az ENSZ-ben? (trstun)

A fenti hét kérdésre adott válaszok alapján határozhatjuk meg a válaszadók intézményekbe vetett bizalmát. Elemzésünkben nem végeztük el az egyes intézmények egyenkénti elemzését, hanem már az első lépésben megvizsgáltuk a 
Cronbach Alfa statisztika segítségével, hogy a hét változó egy vagy többdimenziós struktúrát rejt, illetve, hogy megfelelően fedi-e le a skála az intézményekbe vetett bizalom koncepcióját. Adataink egydimenziós jelleget mutatnak, ezt támasztotta alá az elvégzett faktorelemzési kísérlet, illetve a skálatesztelési eljárás is. A statisztika értéke: Cronbach Alfa 0,897, ami igen magas érték, majdnem tökéletes leképezését jelzi az intézményekbe vetett bizalom koncepciójának a változók által. Ez az eredmény lehetővé teszi, hogy főkomponens elemzés segítségével egy változóba gyüjtsük a hét item információtartalmát, és elmentsük az adott változó főkomponens pontszámait el. A fökomponens modell megörzött varianciája 55\%. A főkomponens értékek segítségével végeztük el a regionális összehasonlításokat. Az eredményeket a 11. ábra tartalmazza.

\section{1. ábra - Intézményekbe vetett bizalom: Fökomponens pontszámok regionális összehasonlítása (standardizált)}

Fökomponens pontszám átlag

Átlag

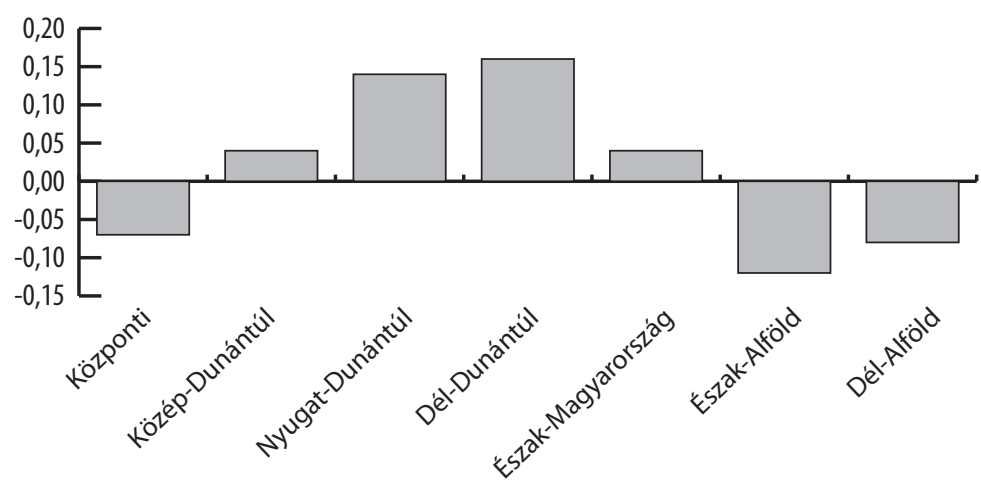

A 12. ábra adatai alapján leolvasható, hogy regionális összehasonlításban az intézményekbe vetett bizalom értéke a dél-dunántúli régióban a legmagasabb, melyet a Nyugat-Dunántúl követ hasonló értékkel. A harmadik dunántúli régió, a KözépDunántúl a harmadik helyet foglalja el az intézményekbe vetett bizalom szempontjából, és ezt az észak-magyarországi régió követi, még pozitív pontszámmal. 
A központi régió és a dél-alföldi régió egyaránt negatív pontszámmal, hasonló értékkel bír, ezekben a térségekben az intézményekbe vetett bizalom mértéke igen alacsony. Meglepő a központi régió negatív értéke, hiszen az általánosított személyközi bizalom szempontjából e régió foglalta el az első helyet, míg az intézményekbe vetett bizalom szempontjából csupán az ötödik. Az utolsó helyen az intézményekbe vetett bizalom szempontjából az észak-alföldi régió áll.

Amennyiben össze kívánjuk vetni az általánosított interperszonális és intézményekbe vetett bizalom regionális eredményeit, segítségünkre lehet a 6. táblázat, mely az egyes régiók fókomponens pontszám átlagát mutatja be a két bizalomtípus szempontjából.

\section{6. tábla - Az egyes régiók helyezései a két bizalomtípus szempontjából. (Fökom- ponens pontszám átlag alapján)}

\begin{tabular}{|l|l|l|}
\cline { 2 - 3 } \multicolumn{1}{c|}{} & \multicolumn{2}{l|}{ Bizalom típusa: } \\
\hline Régió & Intézményi & Személyközi \\
\hline Központi & 5 & 1 \\
\hline Közép-Dunántúl & 3 & 3 \\
\hline Nyugat-Dunántúl & 2 & 2 \\
\hline Dél-Dunántúl & 1 & 5 \\
\hline Észak-Magyarország & 4 & 6 \\
\hline Észak-Alföld & 7 & 4 \\
\hline Dél-Alföld & 6 & 7 \\
\hline
\end{tabular}

A táblázatból leolvasható, hogy két térség, a Nyugat-Dunántúl (2.) és a KözépDunántúl (3.) egyaránt tartja helyezését mindkét bizalomtípus szempontjából, azok egyformán magasak mindkét térségben. A központi régió és a dél-dunántúli régió helyet cserélt intézményi és személyközi bizalom szempontjából. A főváros térségében a személyekbe vetett bizalom magasabb, mint az intézményekbe vetett, míg ez a Dél-Dunántúlon pont fordítva tapasztalható. A Dél-Alföld mindkét bizalomtípus szempontjából egyaránt a lista végén (6, illetve 7.) helyezkedik el. Ebben a régióban a bizalom mindkét típusa egyaránt alacsony. Az Észak-Alföldön inkább a személyközi bizalom az erősebb, az intézményekbe vetett gyengébb, míg ÉszakMagyarországon az intézményekbe vetett bizalom az erősebb és a személyekbe vetett kevésbé jelentös. 
A mélyebb összefüggések, illetve a fellelt különbségek okainak további feltárása érdekében régiónként megvizsgáltuk az intézményekbe vetett bizalom koncepció változóinak átlagait. Elemzésünk eredményeit a 7. táblázat tartalmazza.

\section{7. tábla - Az intézményekbe vetett bizalom átlaga változónként és régiónként (1-10 skála, átlag érték)}

\begin{tabular}{|l|l|l|l|l|l|l|l|l|}
\hline Intézmény: & Országos & Központi & NYD & KD & DD & ÉM & ÉA & DA \\
\hline Rendőrség & 5,22 & 4,84 & 5,61 & 5,28 & 5,45 & 5,35 & 5,1 & 5,25 \\
\hline Jogrendszer & 4,41 & 4,37 & 4,56 & 4,45 & 4,69 & 4,29 & 4,23 & 4,43 \\
\hline $\begin{array}{l}\text { Európai Parla- } \\
\text { ment }\end{array}$ & 4,99 & 4,8 & 5,19 & 5,36 & 5,61 & 5,03 & 4,41 & 4,82 \\
\hline ENSZ & 5,48 & 5,24 & 5,48 & 5,88 & 6,04 & 5,67 & 5,08 & 5,23 \\
\hline Parlament & 3,41 & 3,51 & 3,68 & 3,52 & 3,65 & 3,32 & 3,08 & 3,16 \\
\hline Pártok & 2,62 & 2,61 & 2,87 & 2,5 & 2,57 & 2,85 & 2,42 & 2,57 \\
\hline Politikusok & 2,55 & 2,53 & 3,15 & 2,54 & 2,4 & 2,63 & 2,38 & 2,36 \\
\hline
\end{tabular}

$\mathrm{Az}$ átlagok is kitűnően alátámasztják azt az eredményt, amit a főkomponens pontszámok összehasonlító elemzésével már korábban megismerhettünk: a központi régió átlag pontszámai valóban alacsonyabbak a Nyugat-Dunántúlhoz és a Közép-Dunántúlhoz képest, míg a dél-dunántúli régió átlagai kimagaslóak, kivéve a politikusokba és pártokba fektetett bizalom tekintetében.

\subsubsection{Többdimenziós skálázás az intézményekbe vetett bizalom változóira}

A fentiek alapján kitünik, hogy az egyes régiókban eltérő az intézményekbe vetett bizalom mértéke, ám arról, hogy a különbségeket milyen jellegü eltérés okozza, egyelőre nem rendelkezünk információkkal. A térségek intézményi bizalmi arculatát a többdimenziós skálázás módszerével próbáltuk meg feltérképezni, amely az egyes változókat kétdimenziós térben ábrázolja, egymáshoz viszonyított távolságuk, illetve közelségük alapján (Székelyi-Barna 2002). A többdimenziós skálázás módszere statisztikai elemzési és grafikus ábrázolási lehetőséget biztosít kiválasztott változóink alapján. Az eljárás az egymáshoz viszonyított kapcsolatuk alapján a vizsgált változókat elhelyezi a pszichikus térben, melyből hasznos információk 
nyerhetők az adatok esetleges további jellemzőivel kapcsolatban. Használati értéke igen magas, hiszen a többdimenziós statisztikai elemzések viszonylag kevés ilyen jól kombinált lehetőséget nyújtanak a kvalitatív és kvantitatív változók vizsgálatához. A módszer lehetővé teszi, hogy térbeli megjelenítését adjuk változóinknak, hasonlóságuk vagy különbözőségük alapján. A kétdimenziós térben vizsgálhatjuk meg kapcsolataikat, egymáshoz való viszonyaikat. Az egyes változók különbségeit meg fogja mutatni távolságuk illetve a koordinátarendszer tengelyei mentén elfoglalt helyük. Amennyiben két változó közel kerül egymáshoz, hasonlóak, ha távol, különbözőek. Amennyiben egy dimenzióban foglalnak helyet, közelebb állnak egymáshoz, mintha külön dimenzióban lennének.

A módszert az SPSS program MDS - ALSCAL eljárásával hajtottam végre, a változók közötti távolság mérésére az euklideszi távolságmérési módszert alkalmaztam. A változókat kivétel nélkül a szigorúbb mérési szint meghatározási kritérium szerint ordinális mérési szintünek tekintettem. A 12. ábra tartalmazza az országos $\mathrm{MDS}^{17}$ adatok diagramos ábrázolását.

\section{2. ábra - Többdimenziós skálázás adatainak ábrázolás, euklideszi távolság, országos adatok}

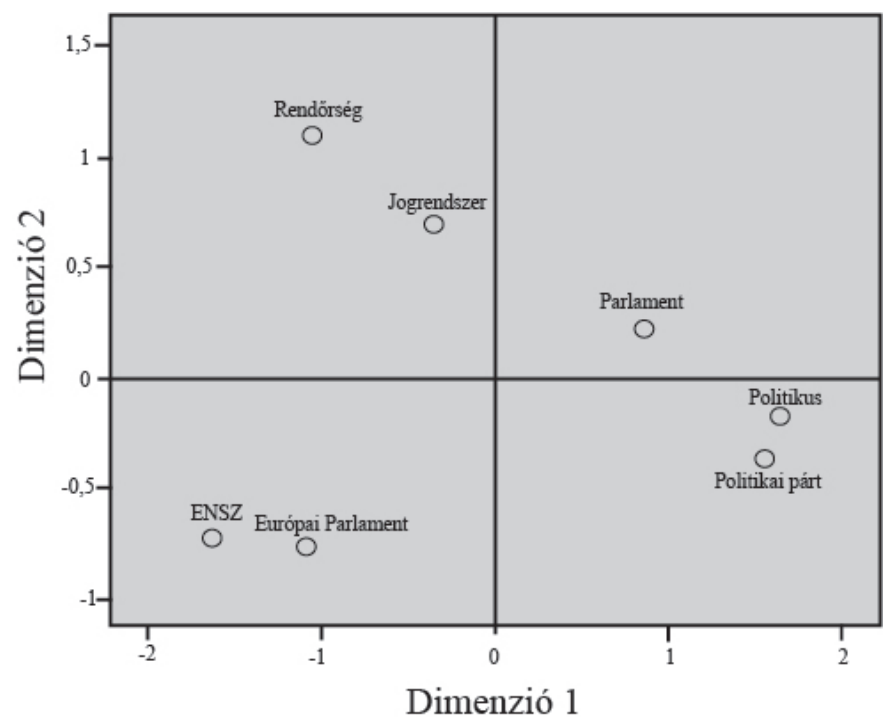

(Stress: 0,00892 R Square: 0,99953)

17 Multidimensional Scaling - Többdimenziós skálázás 
Az országos adatok többdimenziós skálázás Stress és R Square értéke alapján elmondható, hogy a modell illeszkedik. ${ }^{18} \mathrm{Az}$ ábrázolás eredményeinek értelmezése megmutatta, hogy a megkérdezettek hasonlóan gondolkodnak az ENSZ-ról és az Európai Parlamentről, hiszen ezen intézmények igen közel esnek egymáshoz a kétdimenziós térben. Látható azonban, hogy a magyar parlament elkülönül, messze kerül a nemzetközi szervezetektől. Másik dimenzióba is sorolható. Az ábra alapján elmondható, hogy a bizalom mértéke és típusa is más a három szervezet esetében. Az ábrán láthatjuk, hogy a magyar politikai rendszer elemei egymáshoz viszonylag közel kerültek: a politika és a pártok egymáshoz nagyon közel, valamivel távolabb tölük a magyar parlament, a politikához közelebb, a pártoktól valamivel távolabb. Az Európai Parlamentben való bizalom egyformán távol esik az említett három magyar politikai intézménytől. Az EP és az ENSZ egymáshoz való közelségének oka egyfelől a magas fokú bizalom, amit élveznek, másfelől feltehetően a megkérdezettek számára távoli, megfoghatatlan és nehezen értelmezhető jellegük. Mivel a megkérdezett magyar állampolgárok feltehetően nem közvetlenül érzik az említett két szervezet döntéseinek hatását a mindennapi életükben, így a negatív hatások elkerülik őket. A két nemzetközi szervezet sajtója azonban általában igen jó, tehát a média feltehetően pozitívan befolyásolja megítélésüket. Ez az összefüggés megjelenik más kutatók írásaiban is, így Wallace 2005-ös cikke is számot ad a két intézménytípus elkülönülésétől a hagyományos intézményektöl. Magyarország és általában véve az új EU tagállamok esetében jellemzőbb a magasabb fokú bizalom a nemzetközi intézményekben, és az alacsonyabb fokú bizalom a hazaiakban (Wallace 2005, Idézi: Cartwright - Kovács - Sik et al 2006). Az összefüggést a fentiek fényében érdemes régiónként is megvizsgálni, az esetleges különbségek megismerése érdekében.

\subsubsection{Közép-Magyarország}

A modell, melynek ábráját a 13. ábrán láthatjuk a Közép-Magyarországi Régió esetében is megfelelően illeszkedik. Az országos adatokhoz képest eltérés, hogy távolabb kerültek egymástól az Európai Parlamentben és az ENSZ-ben való bizalom változói. Ez a távolság azt mutatja meg számunkra, hogy a régió lakossága jobban megkülönbözteti egymástól a két intézményt. A bizalom a pártokban és a politikában itt is igen

18 A Stress érték minél kisebb, annál megfelelőbb a modell. Az R Square érték elfogadható, ha nagyobb 0,6-nél, és annál jobb, minél közelebb van egyhez. Vö.: Székelyi, M. - I. Barna (2002). Túlélökészlet az SPSS-hez. Budapest, Typotex. 
közel helyezkedik el egymáshoz, ám tőlük a bizalom a magyar parlamentben lényegesen messzebb esik, mint az országos minta esetében. Ez alátámasztja elgondolásomat, miszerint a közelebbi kapcsolat és a nagyobb rálátás képes felfedni egy intézmény „negatívabb” és ,pozitívabb” oldalát is az ahhoz közelebb, illetve avval egy térségben élők számára, ezáltal befolyásolva annak megítélését. Mivel a Közép-magyarországi régió központjában, Budapesten helyezkednek el a magyar politikai és közigazgatási, valamint rendészeti és bírósági szervek csúcsintézményei, így az ott lakók nagyobb eséllyel rendelkeznek ezekkel kapcsolatban saját tapasztalatokkal, mint a más régiókban élő emberek. Ők nem szorulnak rá a kizárólag sajtóból való tájékozódásra, mivel feltehetően dolgoznak az intézményekben ismerőseik, barátaik, családtagjaik, illetve maguk is rászorultak már arra, hogy személyesen ügyeket intézzenek. Ezáltal inkább a személyes tapasztalatok formálják az emberek képét az intézményekről, és nem a sajtó közlései.

Az Európai Parlamentben való bizalomhoz az ENSZ után a jogrendszerben való bizalom változója esik közelebb, nem pedig a magyar parlamentté. Ez azt jelentheti, hogy a Központi Régióban élők az EP szerepét és súlyát talán másként látják, mint az ország más részeiben élő megkérdezettek, és megítélésük szerint az Európai Parlamenti közelebb áll a magyar jogrendszerhez, mint a hazai parlamenthez. Ez azt mutatja, hogy szerintük az EU parlament hatása kodifikációs - jogalkotási területen inkább értelmezhető, mint a politikai szférában.

\section{3. ábra - Többdimenziós skálázás adatainak ábrázolás, euklideszi távolság, Központi régió}

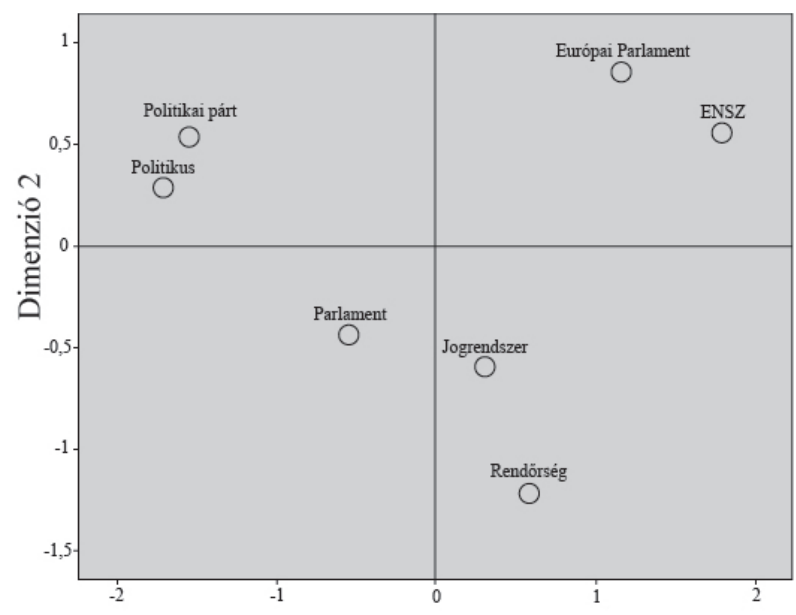

Dimenzió 1

(Stress: 0,012 R Square: 0,998) 


\subsubsection{Nyugat-Dunántúl}

A térség adatait a 14-es ábrán jelenítettük meg, a statisztikai modell ebben az esetben is megfelelően illeszkedik. E régió esetében is hasonló az ENSZ és az EP megítélése a bizalom szempontjából. Ami érdekes, hogy a nemzeti parlamentben való bizalomtól nagyjából egyforma távolságra helyezkedik el a jogrendszerben és a politikában való bizalom, igaz a jogrendszerben való bizalom átlaga természetesen magasabb. Az Európai Parlamenthez ebben az esetben valamivel közelebb esnek a pártok és a politika, mint a nemzeti parlament és a jogrendszer. A magyar politikai rendszer három fontos eleme közül a pártok és a politika nagyon közel esik egymáshoz, ám tőlük a nemzeti parlament távolabb helyezkedik el, ezért nem alkotnak egyértelmüen hármas halmazt. A legnagyobb bizalmat a rendörség élvezi.

\section{4. ábra - Többdimenziós skálázás adatainak ábrázolása, euklideszi távolság, Nyugat-Dunántúl}

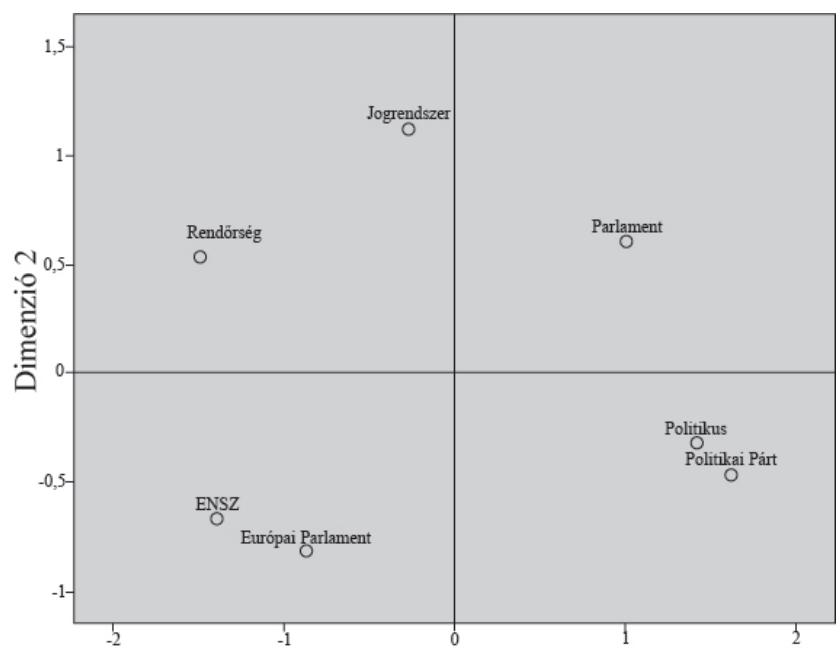

(stress: 0,003 R Square: 0,999) 


\subsubsection{Közép-Dunántúl}

A régiós mintán lefuttatott modell megfelelően illeszkedik, eredményei a 15-ös ábrán láthatóak. A pártokban és a politikában való bizalom e térség esetében esnek legközelebb egymáshoz, a térség lakosai igen hasonló mértékben bíznak a két intézményben. A nemzeti parlament hozzájuk relatíve közel esik. A nemzetközi intézmények esetében elmondható, hogy az ENSZ és az EP bizalma e térség esetében is közel esik egymáshoz, a megkérdezettek hasonlóan gondolkodnak és hasonló mértékü bizalmat biztosítanak a két intézménynek.

\section{5. ábra - Többdimenziós skálázás adatainak ábrázolás, euklideszi távolság, Közép-Dunántúl}

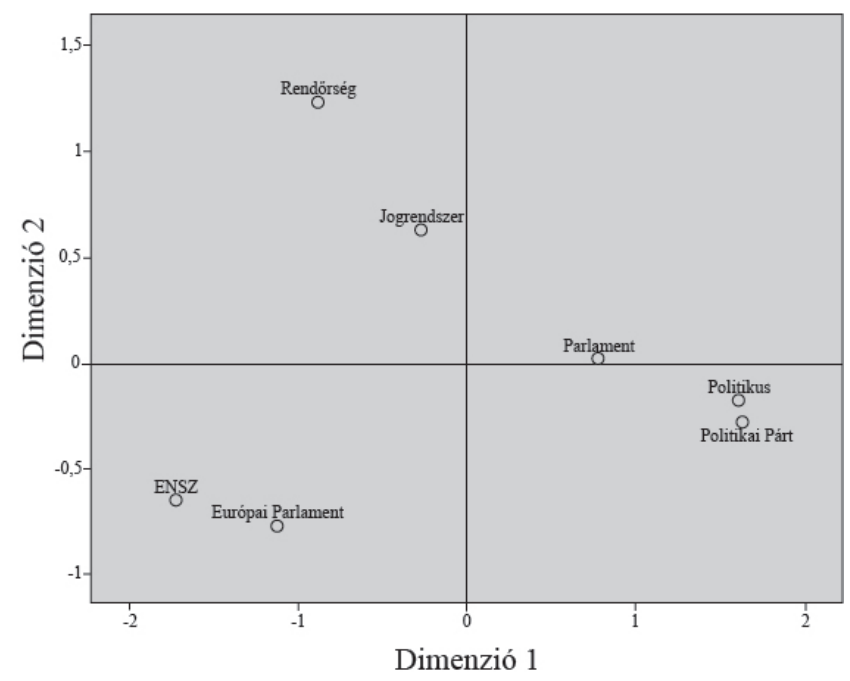

(Stress: 0,024 R Square: 1,00)

\subsubsection{Dél-Dunántúl}

A Dél-Dunántúl adatainak grafikus megjelenítése a 16. ábrán látható, a modell ebben az esetben is megfelelően illeszkedik. E térség esetében került egymáshoz legközelebb az Európai Parlamentbe és az ENSZ-be vetett bizalom az összes vizsgált térség közül. A pártokba és a politikába vetett bizalom ebben az esetben 
is távol van a nemzeti parlamentbe vetett bizalomtól, így a három bizalomtípus hagyományos halmaza nem rajzolódik ki. Az ábrán szembeötlő továbbá, hogy a két nemzetközi intézmény esetében tapasztalt bizalom típus a Dél-Dunántúlon nagymértékben különbözik az összes többi bizalomtípustól, mivel szinte minden más bizalomváltozótól egyformán távol esnek. Alátámasztja ezt az eredményt a két nemzetközi intézménybe vetett bizalomtípus többitől kimagasló átlaga is. A Dél-Dunántúl lakossága a többi térség átlagnál nagyobb mértékben (ENSZ: 6,04-es és EP: 5,61-es átlag) bízik bennük, és a többdimenziós skálázás kimutatta, hogy hasonlóan is gondolkodik róluk adataink alapján.

\section{6. ábra - Többdimenziós skálázás adatainak ábrázolás, euklideszi távolság, Dél-Dunántúl}

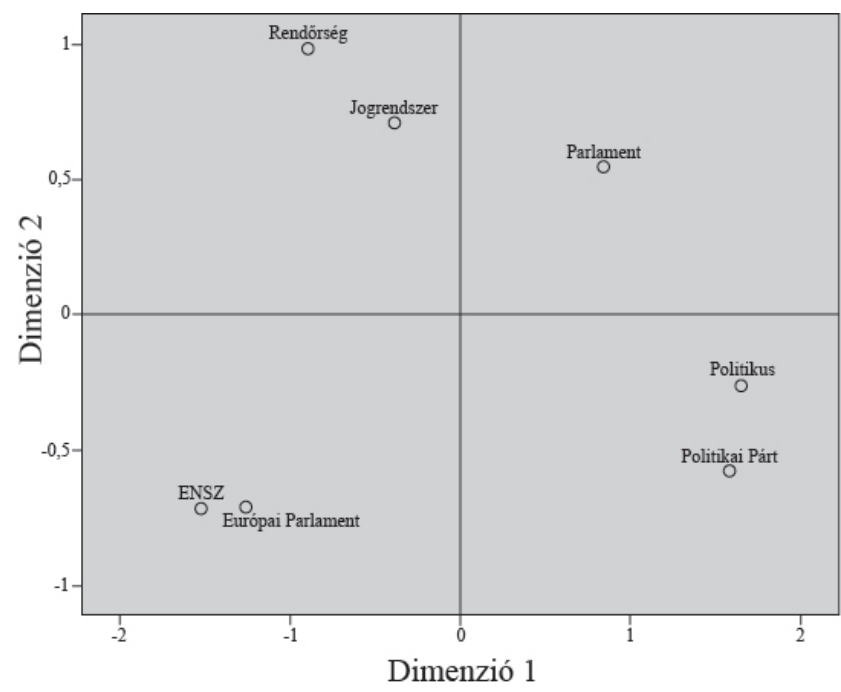

(Stress: 0,005 R Square: 0,999)

\subsection{6 Észak-Magyarország}

A régió adatait a 17-es ábrán láthatjuk. A modell illeszkedése megfelelő. A grafikai megjelenítés alapján látható, hogy régió bizalomtípusai szinte egy ovális alakzatot rajzolnak ki a kétdimenziós térben. Távol esik egymástól az ENSZ-ben való bizalom és az EP-ben való bizalom, ám mégis leolvasható egyféle kapcsolat közöttük. 
A politikába és a pártokba vetett bizalom ebben az esetben közelebb van egymáshoz, ám a harmadik változó, az Országgyülésbe vetett bizalom tőlük kicsit távolabb. A régió intézményekbe vetett bizalomtípusairól készített ábra azt bizonyítja, hogy a régió lakosságának gondolkodásában nem tartozik összes szorosan két vagy több bizalomtípus.

\section{7. ábra - Többdimenziós skálázás adatainak ábrázolás, euklideszi távolság, Észak-Magyarország}

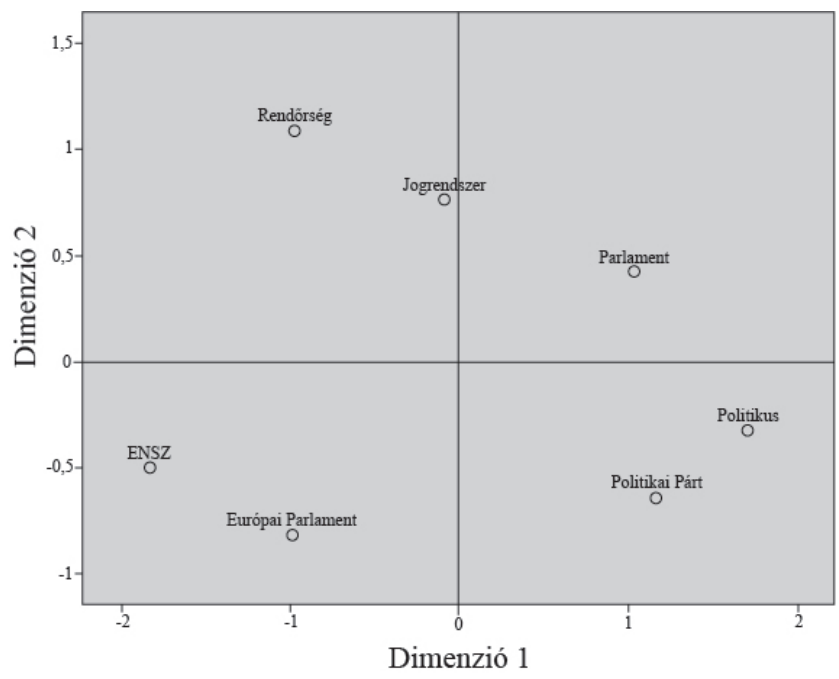

(Stress: 0,017 R Square: 0,997)

\subsection{7 Észak-Alföld}

Az Észak-Alföld esetében a modell illeszkedése megfelelő, az adatok a 18-as ábráról olvashatóak le. A térség lakossága az ábra tanúsága szerint hasonlóan gondolkodik az Európai Parlamentről és az Egyesült Nemzetek Szervezetéről, a két intézménybe vetett bizalmuk típusa és mértéke hasonló. A pártokba, politikába és parlamentbe vetett bizalom e vizsgált térségi adatai alapján egy halmazba vonhatóak. Az Európai Parlamentbe vetett bizalomhoz az ENSZ után a jogrendszerbe 
vetett bizalom került legközelebb. A legnagyobb bizalmat a térségben a rendőrség élvezi.

\section{8. ábra-Többdimenziós skálázás adatainak ábrázolás, euklideszi távolság, Észak-Alföld}

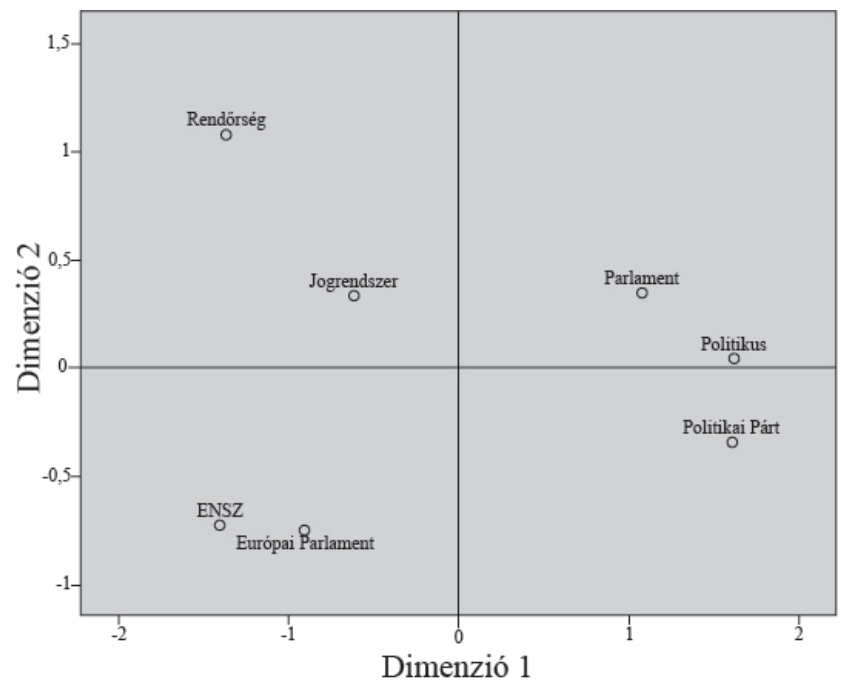

(Stress: 0,004 R Square: 0,999)

\subsubsection{Dél-Alföld}

A dél-alföldi minta alapján végzett elemzés adatait a 19-es ábráról olvashatjuk le. A modell illeszkedése megfelelő. Az eredmények e térség esetében eltérnek az eddig tapasztaltaktól. Az Európai Parlament és az Egyesült Nemzetek szervezet ebben az esetben is hasonló helyre kerültek. Azonban megjegyzendő, hogy az EP-be vetett bizalomhoz a jogrendszerbe vetett bizalom hasonló távolságra van, mint az ENSZ-be vetett bizalom. Ez alacsony Európai Parlamentben való bizalom átlaggal párosul $(4,82)$, illetve megjegyzendő, hogy a térségben a legalacsonyabb a politikusokba vetett bizalom átlaga (2,36). A térségben a Nyugat-Dunántúlhoz és az Észak-Alföldhöz hasonló módon az intézmények közül a legnagyobb bizalmat a rendőrség élvezi (5,25-ös átlag). 


\section{9. ábra - Többdimenziós skálázás adatainak ábrázolás, euklideszi távolság, Dél-Alföld}

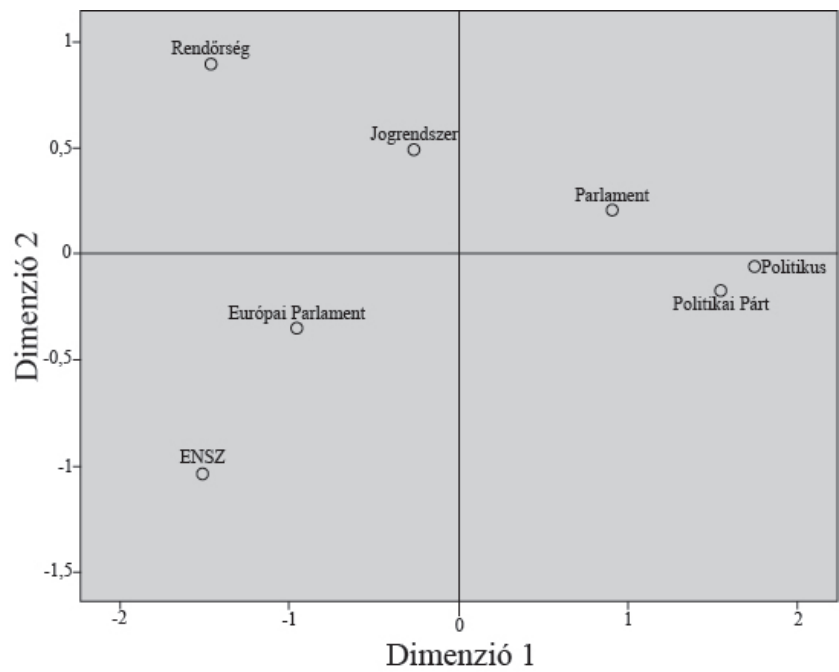

(Stress: 0,015 R Square: 0,998)

\subsection{TANULSÁGOK}

A regionális tendenciák elemzése alapján beigazolódni látszódik hipotézisünk a társadalmi tőke eltérő mértékével és szerepével kapcsolatban Magyarországon. Hazánkban a regionalizmus még fiatal folyamatnak tekinthető, ezért a térségek egyedi arculatának kialakulása még jelenleg is zajlik. Elvégezett elemzéseink azonban megmutatták, hogy a térségek egyedi arculattal rendelkeznek a vizsgált társadalmi tőke dimenziók szempontjából. A kérdés-jelentések mérési invariancia módszertani fejezetben megállapított hiánya ékes bizonyítékként szolgált az egyes térségek lakosságának különböző elgondolásaira az általánosított személyközi bizalom változóival kapcsolatban. A feltételezhető parciális invariancia pedig annak tudható be, hogy a régiók lakossága hasonló kulturális és társadalmi körülmények között szocializálódott.

A régiók intézményesített bizalom változóira végzett többdimenziós skálázás szintén egyedi térségi profilokat eredményezett. A régiók között vannak hasonlóságok, de különbségek is a vizsgált bizalomtípusok és összefüggéseik tekintetében. A kutatást ezért mindenképpen érdemes volt kiterjeszteni az egyes régiók vizsgálatának a szintjére. 


\section{A TERÜLETI KÖTŐDÉSEK ELEMZÉSE A NEMZETI ÉS A REGIONÁLIS TERÜLETI SZINTEKEN}

A területi kötödéssel kapcsolatos elemzéseim elkészítéséhez az Eurobarometer vizsgálat következő hullámait használtam fel: 62.0 (2004. október-november), 63.4 (2005. május-június), 65.2 (2006. március-május), 67.1 (2007. február-március), 67.2 (2007. április-május). Az országos minták regionális szinten reprezentatívak, a mintanagyság általában ezer fő körüli. Az adatelemzések a Kölni „Zentral Arhiv” által biztosított hivatalos adatfájlokon, kizárólag a magyar eseteket figyelembe véve zajlottak. Az egyes adatfeldolgozási nehézségekről minden esetben annál a résznél írok, ahol a nehézség felmerült.

A területi kötődést mérő kérdés az Eurobarometer kérdőív különböző hullámaiban az alábbi formában került lekérdezésre:

„Az emberek különbözö mértékben kötődhetnek a városukhoz vagy falujukhoz, a régiójukhoz, az országukhoz, Európához. Kérem, mondja meg, menynyire kötödik Ön ...

városához/falujához,

régiójához,

Magyarországhoz,

Európához.

Válaszlehetöségek: 4. Nagyon kötödik; 3. Eléggé kötödik; 2. Nem nagyon kötődik; 1. Egyáltalán nem kötödik." (Eurobarometer kérdöív, már átkódolt értékek)

A kérdés szövege standardizált, minden egyes hullámnál ugyanebben a formában kerül be a kérdőívbe, ezáltal idősorosan összehasonlíthatóak az egyes 
vizsgálatok adatai. Az Eurobarometer interjúszituáció területi egységeinek jelentéseivel kapcsolatban lásd az 1. táblát. A kérdőív a potenciális kötődések tárgyául szolgáló területi szintek közül négyet emel ki, a települést, a régiót, az országot és Európát/az Európai Uniót. ${ }^{19}$ Ezen szintek esetében válik lehetségessé az idősoros adatok összehasonlítása, a területi kötődést vizsgáló kérdésekre adott válaszok öszszehasonlító elemzése. A magyar helyzetben kifejezetten fontos megyei szint elemzésére a kategória hiánya, illetve a fenti, standardizált kérdésformátum miatt ebben a fejezetben nem adódik lehetőségünk.

A válaszlehetőségek alapján a kérdés mért eseteit tartalmazó változót tekinthetjük intervallum (magas) mérési szintünek és ordinális (alacsony) mérési szintünek egyaránt. Mivel megfelel a kritériumoknak, és kellően nagy az elemszám, az egyváltozós elemzések elvégzésekor intervallum mérési szintű változónak fogom tekinteni, és a kötődés adatok esetében átlagot, valamint szórást fogok számítani. Többváltozós elemzések elvégzésekor azonban ordinális mérési szintűnek fogom tekinteni a változót a kategóriák alacsony ${ }^{20}$ száma miatt (Schumacker - Lomax 2004).

\subsection{KORRELÁCIÓS VIZSGÁLATOK}

Elemzésem első lépéseként a kötődéseket mérő változók közötti kapcsolatokat próbáltam feltérképezni. A különböző kötődések egymáshoz való kapcsolatát a korreláció eljárásával vizsgáltam. Az adatok jellege miatt a Spearman ${ }^{21}$ korrelációs együttható használata mellett döntöttem. A korrelációs eljárás a változók közötti kapcsolat meglétét vizsgálja. Amennyiben létező kapcsolatot találunk a segítségével, meg is mutatja annak erősségét. Az eredményeket a 8. táblázat tartalmazza. A táblázat adataiból leolvasható, hogy minden területi szinthez való kötődés szignifikáns kapcsolatban van az összes többi területi szinthez való kötődéssel (az

19 A 2006-ban zajló 65.2-es Eurobarometer felmérésnél a megkérdezettek felétől az Európához való kötődésükről, a másik felénél az Európai Unióhoz való kötődésükről érdeklődtek. Az Európai Unióhoz való kötődés lényegesen gyengébbnek bizonyult az Európához kötődésnél. A két fogalom kognitív tartalmának vizsgálatára jelen munka esetében nem kerítek sort. A 2006-os adatokból csak azt a mintarészt vizsgálom az Európai kötődés esetében, amelynek a standardizált kérdést tették fel.

20 A változót akkor tekinthetjük nagy biztonsággal intervallummérési szintűnek, ha kategóriáinak a száma meghaladja a 15-öt. Jelen változó csupán négy kategóriával rendelkezik.

21 A Spearman korreláció használatát az indokolta, hogy a változók adatai nem követtek normális eloszlást, és nem feleltek meg a magas mérési szintủ korreláció követelményeinek. A kapcsolat erőssége rangértékek kiosztása alapján került kiszámításra. 
Alfa $=0,01$-es valószínüségi szinten). A kapcsolatok erősségét az együtthatók nagysága mutatja meg. Az együtthatók elemzése alapján érdekes tendencia rajzolódik ki: a település minden esetben a régióval mutatja a legnagyobb mértékü korrelációt, azt követi erősségben az ország, majd az Európai Unió. Ez lényegében azt jelenti a számunkra, hogy minél inkább távol kerülünk a lokalitás határaitól, az emberek kevésbé kötődnek az adott területi szintekhez. Ez az eredmény összhangban van az Európai Unió által felismert ténnyel, miszerint a közösség (EU) túl távol van a polgárai mindennapi életétöl, s ezáltal az kevéssé része kötődései rendszereiknek.

\section{8. tábla - Területi kötődések korrelációs mátrixa, idősorosan}

\begin{tabular}{|l|l|l|l|l|}
\cline { 2 - 5 } \multicolumn{1}{c|}{} & $2004.10-11$. & $2005.05-06$. & $2006.03-05$. & $2007.02-03$. \\
\hline település - régió & $0,705^{* *}$ & $0,737^{* *}$ & $0,797^{* *}$ & $0,726^{* *}$ \\
\hline & $2004.10-11$. & $2005.05-06$. & $2006.03-05$. & $2007.02-03$. \\
\hline település - ország & $0,508^{* *}$ & $0,518^{* *}$ & $0,545^{* *}$ & $0,488^{* *}$ \\
\hline & $2004.10-11$. & $2005.05-06$. & $2006.03-05$. & $2007.02-03$. \\
\hline település - Európa & $0,345^{* *}$ & $0,383^{* *}$ & $0,413^{* *}$ & $0,298^{* *}$ \\
\hline & $2004.10-11$. & $2005.05-06$. & $2006.03-05$. & $2007.02-03$. \\
\hline régió - Európa & $0,523^{* *}$ & $0,567^{* *}$ & $0,463^{* *}$ & $0,388^{* *}$ \\
\hline & $2004.10-11$. & $2005.05-06$. & $2006.03-05$. & $2007.02-03$. \\
\hline régió - ország & $0,549^{* *}$ & $0,555^{* *}$ & $0,583^{* *}$ & $0,555^{* *}$ \\
\hline & $2004.10-11$. & $2005.05-06$. & $2006.03-05$. & $2007.02-03$. \\
\hline ország - Európa & $0,520^{* *}$ & $0,563^{* *}$ & $0,495^{* *}$ & $0,386^{* *}$ \\
\hline Az összefüggés szignifikáns: **0,01 valószínúségi szinten. Spearman korreláció. \\
\hline
\end{tabular}

Ha a régió-Európa és a régió-ország kötődéseket vizsgáljuk, 2004-ben és 2005ben hasonló eredményeket kapunk. 2006-ban és 2007-ben azonban az együttható értéke, azaz a kapcsolat erőssége egyértelmủen gyengült a régió-Európa kapcsolati relációban, bár továbbra is szignifikáns maradt. A régió-ország korrelációs együttható értéke stagnált. Összességében elmondható, hogy a kötődések korrelációja az Európához történő kötődéssel 2007-re minden esetben csökkent. A Magyarországhoz és Európához kötődés között kapcsolat erősségének változásai is érdekes trendet mutatnak, hiszen míg az együttható szinte változatlan 2004-ben és 2005-ben, kissé 
csökken 2006-ra, és nagymértékben csökken 2007-re. A csökkenés mértéke hasonló a régió-Európa kapcsolat erösségének csökkenéséhez.

A korrelációs együtthatók nagyságának időbeli változásai segítségünkre voltak egy az euroszkepticizmus növekedésével járó tendencia azonosításában, mely hatással van az Európához történő kötődésre is. Vélhetően az EU csatlakozás után eltelt évek realitása, illetve a gyors gazdasági siker elmaradása és Európa „távoliságának" felismerése erodálta a lakosság kötődését ehhez a területi szinthez.

\subsection{KERESZTTÁBLA ELEMZÉSEK}

A korrelációs együtthatók vizsgálata után elkészítettük az egyes változók kereszttáblázat összevetéseit. A kereszttáblázatokban együttesen jelenítettük meg a különböző területi szinteket, melyekhez a megkérdezettek kötődnek, páronként. Az 9. táblázatban kizárólag a „Nagyon kötődik” válaszok páronkénti metszeteit jelenítettük meg, százalékos formában, azaz azt vizsgáltuk, hogy mely területi szintekhez történő kötődéseknél találhatóak nagyobb, illetve kisebb mértékü átfedések a válaszokban.

A település és régió, illetve a település és ország kapcsolata ezen százalékos adatok alapján is kiegyensúlyozottnak tetszik az idő múlásával is. A százalékos arányok csupán kismértékben változtak, egy szinten mozogtak, jelentős növekedés vagy csökkenés nem volt tapasztalható. Azonban a településhez és Európához egyaránt nagyon kötödök aránya a 2005-ös 55\%-ról 2006-ra lecsökkent 42,5\%-ra, 2007-re pedig 38,5\%-ra. melyet igen jelentős csökkenésnek tekinthetünk. Ez egybeesik a korrelációs együtthatók esetében tapasztaltakkal, azaz az Európához kötődés minőségének változása (az adatok alapján egyértelmüen csökkenése) ezen táblázatból is megfigyelhető.

A régiós és Európai kötődés viszonya nagyjából stabil maradt, a kötődések nagyjából azonos százalékban esnek egybe az egyes időpontokban. Változott azonban Magyarország és a régió, valamint Magyarország és Európa egybeeső kötődéseinek aránya, a település és Európa kötődési pár változásaihoz hasonlóan. A 2005-ös kötődési egybeesési csúcsról az egybeeső százalékok 2006-ra lecsökkentek és 2007-re tovább csökkentek.

A legmagasabb kötődési egybeesési százalékos arányok minden változópár esetében a 2005. május-júniusban végzett felmérés adatai esetében tapasztalhatóak, egy évvel Magyarország Európai Uniós integrációja után. Azt feltételezzük, hogy az euro-optimizmus mértéke ekkor volt a legmagasabb. Ekkor még nem merült fel az integráció hatásainak hidegfejü, tényeken alapuló vizsgálata, sokkal inkább tünhet úgy, 
hogy pozitív, inkább optimista érzület volt uralkodó. „Az Eurobarometer vizsgálatok segítségével 2001-től kezdve nyomon követhető az EU megítélésének alakulása. 2001-ben a megkérdezettek 71 százaléka gondolta azt, hogy az EU tagság az ország számára előnyös lesz, 59 százalék pedig úgy vélte, hogy az EU általában véve jó dolog. Ez az arány folyamatos csökkenést mutatott mindkét kijelentés tekintetében, és már az EU-csatlakozás évében, a 2004-es év végén azt lehetett látni, hogy a válaszadók fele sem ért egyet az előbbi két állítással (Lengyel-Göncz 2010). 2006-ban és 2007-ben, amikor az emberek számon kérték a vélt vagy valós ígéretek, illetve hatások megvalósulását a kormányon és az Európai Unión, egyáltalán nem azt kapták, amit akartak. A mindennapi életükben nem jött el az, amit nyugaton láthattak, az uniós csatlakozás hatásainak reális értékelésére csupán a népesség egy szük rétege volt képes. 2005-ben még a csúcson volt az EU csatlakozás előnyeit bemutató média- és PR kampány, sokan hittek benne, hogy valóban „cukrászdát nyithat Bécsben” és más ehhez hasonló marketingszövegek igazságát. A kampány befejeztével, illetve a mindennapi gondok és küzdelmek megmaradtával az emberek elvesztették illúziójukat, euro-optimizmusukat, és elkezdtek kiábrándulni a szupranacionális intézményből.

\section{9. tábla - Teljes kötődés metszet különbözö területi szintek esetében, (\%)}

\begin{tabular}{|l|l|l|l|l|}
\cline { 2 - 5 } \multicolumn{1}{c|}{} & $2004.10-11$. & $2005.05-06$. & $2006.03-05$. & $2007.02-03$. \\
\hline település - régió & $55,80 \%$ & $59,60 \%$ & $56,40 \%$ & $55,50 \%$ \\
\hline & $2004.10-11$. & $2005.05-06$. & $2006.03-05$. & $2007.02-03$. \\
\hline település - ország & $61,50 \%$ & $64,80 \%$ & $58,60 \%$ & $59,20 \%$ \\
\hline & $2004.10-11$. & $2005.05-06$. & $2006.03-05$. & $2007.02-03$. \\
\hline & $44,60 \%$ & $53,60 \%$ & $42,50 \%$ & $38,50 \%$ \\
\hline & $2004.10-11$. & $2005.05-06$. & $2006.03-05$. & $2007.02-03$. \\
\hline régió - Európa - Európa & $58 \%$ & $60,90 \%$ & $57,20 \%$ & $56,50 \%$ \\
\hline & $2004.10-11$. & $2005.05-06$. & $2006.03-05$. & $2007.02-03$. \\
\hline régió - ország & $45,60 \%$ & $54,20 \%$ & $42,50 \%$ & $38,90 \%$ \\
\hline & $2004.10-11$. & $2005.05-06$. & $2006.03-05$. & $2007.02-03$. \\
\hline ország - Európa & $52,60 \%$ & $62,90 \%$ & $48,20 \%$ & $45 \%$ \\
\hline
\end{tabular}




\subsection{A TERÜLETI KÖTŐDÉST MÉRŐ VÁLTOZÓK ÉS AZ ÁLTALUK ALKOTOTT SKÁLA TESZTELÉSE}

A területi kötődés különböző szintjeit mérő változók együttes megbízhatóságáról a „Cronbach Alfa” statisztikai eljárás segítségével bizonyosodhatunk meg. A statisztika lényegében azt elemzi, hogy a vizsgált jelenség mérésére operacionalizált változók alkalmasak-e funkciójuk betöltésére. Az egyes itemek, amelyek egyenként egy-egy terület szinthez való kötődést mérnek, együttesen egy a területi kötődést mérő skálaként funkcionálnak. Ezen skála megbízhatóságát, azaz a segítségével végrehajtott mérések pontosságát teszteli az alfa statisztika (Cronbach 1951; Santos 1999). További kiemelt fontosságú funkciója az eljárásnak, hogy megmutatja, a változók megfelelően reprezentálják-e az egydimenziós teret, vagy esetleg a változók mögött több dimenzió meghúzódására kell számítanunk. A társadalomtudományokban általánosan alkalmazott határszint a statisztikai érték megfelelőségére a 0,7-es. A 10. táblázatban leolvashatóak a skála Cronbach Alfa statisztika értékei, idősoros formában.

\section{0. tábla - Cronbach Alfa együtthatók az adatok egydimenziós illeszkedésére}

\begin{tabular}{|l|l|l|l|l|l|}
\cline { 2 - 6 } \multicolumn{1}{c|}{} & $2004.10-11$. & $2005.05-06$. & $2006.03-05$. & $2007.02-03$. & 2007. 04-05. \\
\hline Cronbach Alfa & 0,774 & 0,809 & $0,775^{*}$ & 0,76 & 0,524 \\
\hline & $*$ Az elemszám 2006-ban 509 fö, a többi esetben a teljes minta \\
\hline
\end{tabular}

A Cronbach Alfa érték megfelelö 2004-ben, 2005-ben, 2006-ban és a 2007. február-márciusi mérés idejekor. Ezekben az időpontokban a vizsgált változók tehát alkalmasak a területi kötődés koncepció mérésére. Megjegyzendő, hogy a legmagasabb a Cronbach Alfa érték 2005-ben, amikor is a kötődési optimizmus szempontjából csúcsidőszakról beszélhetünk. A 2007. április-májusi felmérés esetében azonban a skála a 0,7-es határérték alá csökken (alfa=0,524). Ebben az időpillanatban ez a négy változó nem alkalmas a területi kötődés mérésére, illetve az adatok mögött esetlegesen nem egydimenziós struktúra húzódik meg. A területi szintekkel kapcsolatban feltettük, hogy léteznek „konvencionális” (ország, település) és „új” (Európa, régió) kötődési relációk. Ezek a 2007. április-májusi adatfelvételig alkalmasak is voltak együttesen, egy skálát alkotva a területi kötődés mérésére, ám erre az évre ezt a tulajdonságukat elvesztették. Ennek oka az európai szinthez történő kötődés visszaesésében keresendő. 


\subsection{FAKTORELEMZÉSEK}

A Cronbach Alfa statisztika lefuttatása és eredményeinek értelmezése után faktorelemzési eljárást futtattunk az egyes évek esetében külön-külön a változókra. A faktorelemzésnél a „Maximum likelihood” módszert alkalmaztuk, „Varimax” rotációval, faktorképzési módszernek az 1-es sajátérték feletti dimenziók automatikusan faktorokká alakítását választottuk (Székelyi-Barna 2002). Célunk a „konvencionális” és „új” területi szintek elkülönítése lett volna az eljárás segítségével, illetve a Cronbach Alfa skálatesztelés eredményeinek verifikálása. A 11. táblázatban csupán a rotált faktormátrixokat közöljük, idősoros bontásban.

\section{1. tábla - Rotált faktorközéppontok faktorsúlyai idősoros formában}

\begin{tabular}{|l|l|l|l|l|}
\hline Kötődés típusa & 2004 & 2005 & 2006 & $20074-5$. \\
\hline Település & 0,7641 & 0,7776 & 0,8230 & 0,7831 \\
\hline Régió & 0,8688 & 0,8993 & 0,9196 & 0,9125 \\
\hline Ország & 0,5989 & 0,6220 & 0,5722 & 0,5874 \\
\hline Európa & 0,4976 & 0,5758 & 0,4553 & 0,3997 \\
\hline
\end{tabular}

Az eljárás minden vizsgált évben egy faktort bontott ki, azaz a kötődéseket mérő változok azonos gondolati dimenzióba, feltehetően a „területi” kötődés dimenziójába helyezkedtek el a megkérdezettek gondolkodásában. Azonban a kibontott faktoron belül a változók illeszkedése nem minden esetben volt megfelelö. Az Európához kötődés faktoron elhelyezkedéshez szükséges 0,5-es konvencionális ${ }^{22}$ faktorsúly határértéket csupán 2005-ben haladta meg. A változó kilógott a faktorról 2004-ben, 2006-ban, és faktorsúlya, azaz a faktoron helyét jelző érték 2007-ben a legkisebb (0,3997), határérték alatt.

Ennek fényében megállapítható, hogy a megkérdezettek területi kötődéseikről egydimenziós formában gondolkodnak, és ebben az egydimenziós gondolkodásban állandó helye van a településhez, az országhoz és a régióhoz való kötődésnek.

22 Egy változót akkor tekinthetünk kizárólag egy faktoron ülőnek, ha annak faktorsúlya meghaladja a 0,5-et, illetve egyetlen más faktoron sem helyezkedik el a legnagyobb faktorsúlyának 50\%-át meghaladó mértékben. Székelyi, M. - I. Barna (2002). Túlélőkészlet az SPSS-hez. Budapest, Typotex. 
Magyarország EU csatlakozása után 1 évvel bekerült e három változó mellé az Európához kötődés is, ám a későbbiekben $(2006,2007)$ ki is került onnan. Ez a statisztikai elemzés is igazolni látszik feltételezésünket, miszerint Magyarországon az EU csatlakozás után lezajlott egy a közösség iránti fellángolás, ami azonban 2006-re és főként 2007-re már elmúlt.

\subsection{KÖTŐDÉS A TERÜLETI SZINTEKHEZ}

\subsubsection{Település}

A településhez kötődés átlagát régiónként a 21 -es ábrán jelenítettük meg. Elmondható, hogy 2004-ben a nyugat-dunántúli régió lakosai kötődtek leginkább a településükhöz, mely kötődés 2005-re tovább erősödött, 2006-tól pedig folyamatosan csökkent, és 2007-ben a régió a középmezőnybe került. Az észak-magyarországi régió lakosságának településhez kötődése 2004-ben volt a legmagasabb, 2005-ben és 2006-ban csökkent, 2007-ben kismértékben visszaerősödött, azonban így is az utolsó helyen van a régiók településhez kötődési rangsorában. A régió lakossága 2004-ben még a magyar régiók között a második helyen volt a kötődés szempontjából, ám 2007. április-májusra az utolsó helyre esett vissza. Itt kell azonban megemlíteni egy fontos trendet, mely a település és az országos szint esetén is megfigyelhető a területi egység esetében: 2006-ról 2007-re erősödés történik. A hagyományos területi struktúra elemeihez való kötődés - azaz a településhez való kötődés - erősödik, míg az „új”, európai területi struktúra elemeihez - azaz a régióhoz és Európához - való kötődés tovább gyengül. Ez a jelenség arra utal, hogy egyféle területi kötődési elkülönülés alakult ki a térség lakosainak gondolkodásában, kötődéseiben a régi és az új területi egységek között.

A dél-alföldi régió 2004-es harmadik helyéről az első helyre került 2007-re, ebben a térségben a lakosság települési kötődése folyamatosan nőtt. Az észak-alföldi régióban is erősödő tendencia jellemezte a területi kötődést. A Dél-Dunántúlon a kötődés 2004-től 2006-ig gyengült, majd 2007-re felerősödött, ám a 2007-es végállapot szerint a településhez kötődés nem kifejezetten erős a lakosság körében. A központi régió és a Közép-Dunántúl települési kötődései hasonlóan alakultak az idősoros elemzés folyamán, enyhe növekedést mutatott a két trendvonal. 


\section{0. ábra - Településhez kötődés átlaga idősorosan, régiónként (min. 1-max. 4)}

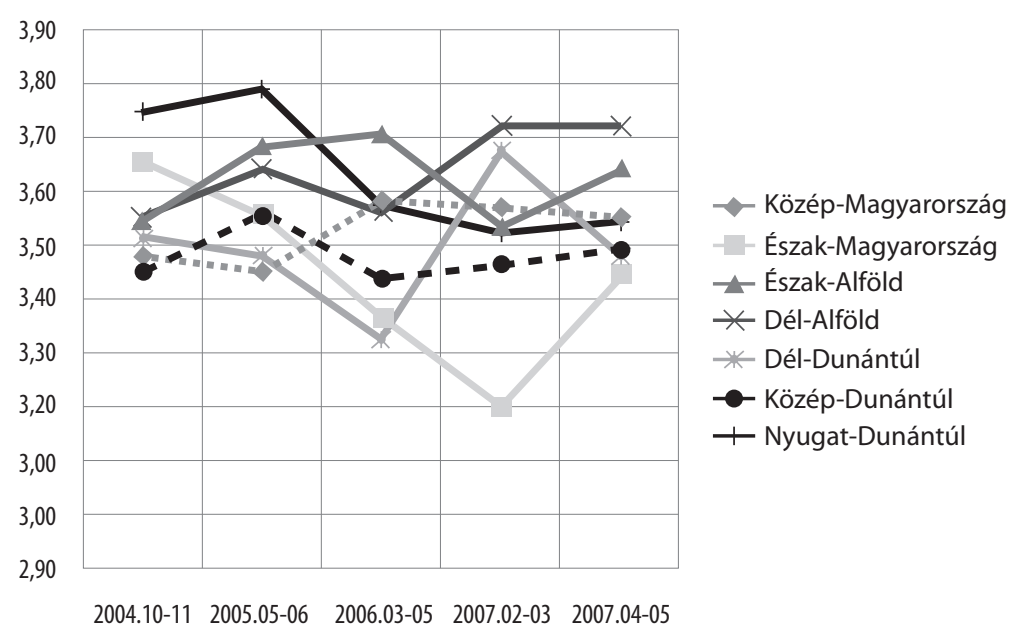

\subsubsection{Régió}

A régióhoz kötődés átlaga (22. ábra alapján) 2004-ben és 2005-ben a Nyugat-Dunántúl esetében volt a legnagyobb, ám ez 2006-ra lecsökkent, amikor a harmadik helyre szorult, és további enyhe csökkenés után 2007-ben a második helyre került. A gazdasági szempontból rendkívül sikeres régió polgárai erősen kötődnek saját régiójukhoz. A dél-dunántúli régió lakosságának regionális kötődési átlaga 2004ben a második legerősebb volt, mely 2005-ben és 2006-ban folyamatos csökkenés után a negyedik helyre került. 2007-re enyhe erősödés után a lakossági kötődések átlaga a regionális rangsor harmadik helyére jött fel.

$\mathrm{Az}$ észak-magyarországi régió lakosságának regionális kötődésének erőssége 2004-ben a harmadik legerősebb volt a régiók rangsorában, mely azonban jelentős csökkenés után 2005-re a hatodik helyre került, és további folyamatos csökkenés után 2006-ban és 2007-ben az utolsó helyen állt. A térség trendvonala folyamatos csuszamlás-szerü esést mutat az idősoron, ami a magyar régiók között egyedi. A másik hat régió kötődési átlagai 2007-ben 3,45 és 3,65 között csoportosulnak, s ettől nagy szakadék választja el a 3,15 körüli szinten álló észak-magyarországi átlagot. Ezen tendencia riasztó voltára a térség kötődéseinek elemzésekor külön felhívjuk a figyelmet.

A dél-alföldi régió lakosságának kötődési átlaga 2004-ben a negyedik helyen állt a magyar régiók rangsorában, 2005-re emelkedő tendenciát mutatva a harmadik 
helyre került, 2006-ra lecsökkent, visszaesett az ötödik helyre, ám a régiók közül a legnagyobb erősödést produkálva 2007-re a legmagasabb kötődési átlagot érte el. A 2006-ról 2007-re történő nagymértékű erősödés okát nem ismerjük, ám kétségtelenül nagyobb mértékủ volt, mint a 2005-röl 2006-ra lezajlott csökkenés. Az észak-alföldi régió lakosságának regionális kötődési átlagai 2004-től 2006ig erösödtek, amikor is igen jelentős csökkenés volt tapasztalható. Ezen jelentős csökkenéssel az Észak-Alföld a második volt a 2006-ról 2007-re a regionális kötődés átlagának csökkenését produkáló magyar régiók között, Észak-Magyarország után és Közép-Magyarország előtt.

A közép-dunántúli régió lakosságának regionális kötődési átlagértéke 2004ben a hatodik helyen áll, ahonnan kis emelkedés után 2005-ben az ötödikre kerül. Enyhe csökkenés után tartja a helyét 2006-ban, és jelentős erősödéssel 2007-re a regionális átlagrangsor negyedik helyére hozza fel. A régió lakossága körében az erős regionális kötődés egyik időpillanatban sem volt jellemző, a területi szint inkább az elfogadott, de nem vonzó kötődési kategóriába került be.

2004-ben a közép-magyarországi régió lakosai a legkevésbé kötődőek. Ez a helyezés stagnálás mellett 2005-ben megmarad, amit 2006-ra nagymértékű erősödés követ. A régió ekkor a második helyre kerül a magyar régiók kötődési átlagrangsorában. Ezen érték enyhe csökkenésével a térség 2007-re a negyedik helyre szorul vissza, ami azonban kiinduló utolsó helyéhez képest igen komoly változás.

\section{1. ábra - Régióhoz kötődés átlaga idősorosan, régiónként (min. 1 - max. 4)}

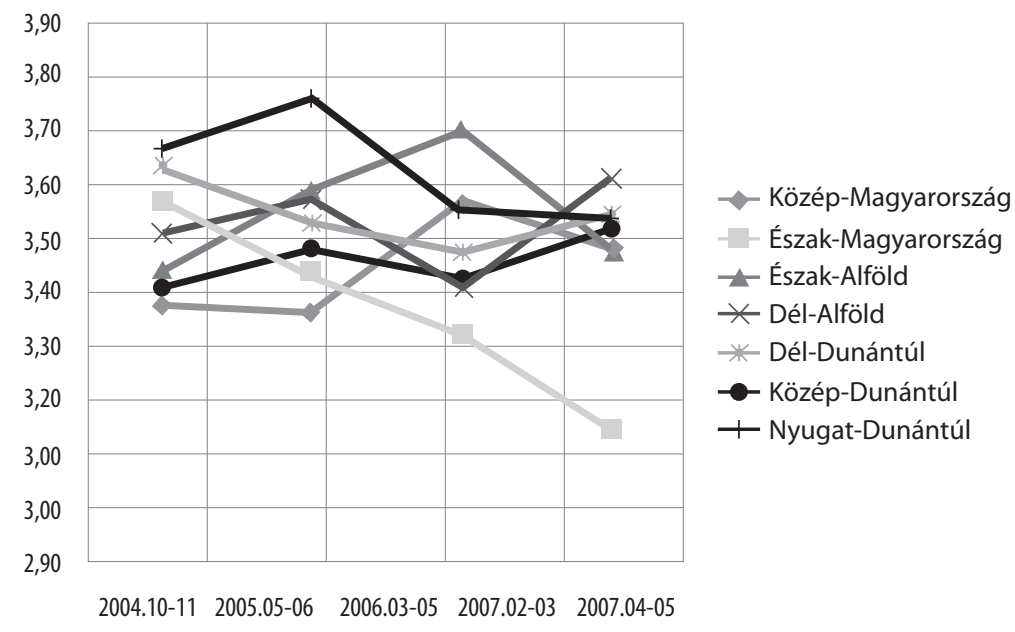




\subsubsection{Ország}

Az országhoz való kötődés szempontjából (23. ábra) az észak-alföldi régió lakosai állnak 2004-ben az első helyen (3,8-as átlag), holtversenyben a Dél-Dunántúllal. Ezen első helyet egy százados különbséggel holt versenyben 2005ben és 2006-ban is örzi a térség, ám ekkor már más régiókkal szemben. 2007 első adatfelvételi időpontjára az átlagérték csökken, és a térség visszaszorul a második helyre, melyet 2007 második adatfelvételi időpontjában is öriz, enyhe gyengülés mellett. A trendvonal nem mutat lényeges változásokat, ugrásokat az egyes időpontok között.

A Dél-Dunántúl 2005-ben nagy átlagcsökkenéssel visszaszorult a holtversenyben első helyértől az utolsóra, innentől fogva pedig az átlagérték stagnál, és a régió helyezésének változása a rangsorban csupán a többi régióban lezajló mozgások miatt történik.

2004-ben az országos kötődések szempontjából a harmadik $(3,78)$ helyen az észak-magyarországi régió lakossága állt, ami 2007. február-márciusáig azonban zuhanó tendenciát mutatott az országhoz való kötódés viszonylatában. 2006-óta a legutóbbi publikált adatfelvételig a régió lakosságának országhoz való kötődés átlaga a magyar régiók közül a legalacsonyabb, a rangsorban a térség az utolsó helyen áll. 2007. február-március után azonban jelentős erősödés tapasztalható a régió lakosságának országos kötődéseiben; 2007. április-májusra az országos szinthez való kötődés erösödése volt tapasztalható.

Közép-magyarország lakossága, azaz a budapestiek és a Pest megyeiek 2004ben holtversenyben a negyedik helyen (3,77-es átlag, csak három század különbség az első helyhez képest) kötődtek leginkább Magyarországhoz, azonban ezen kötődési átlag jelentős csökkenésével 2005-re a térség lakosai az utolsó helyre estek, és ettől fogva egy szinten stagnáló átlagértéket produkáltak a kötődések szempontjából. Innentől tehát nem a régió lakosságának kötődésváltozásai határozták meg a régió helyét az országhoz való kötődés rangsorában, hanem a többi régióban lezajló változások.

A másik egyenlő értékkel negyedik, az országos szinthez leginkább kötődő régió a Nyugat-Dunántúl. A régió lakosságának az országos szinthez való kötódése 2005-re erősödött, ám ettől kezdve minden adatfelvételi időpontban enyhén csökkent, őrizve ezzel a térség helyét az első-második helyek valamelyikén. A nyugat-dunántúli lakosság egyértelmủen, időbeni viszonylatban is magas átlaggal kötődik a nemzeti szinthez. 
Az országos kötődés szempontjából a hatodik helyen a Közép-Dunántúl áll, ahol az idősoros trendvonalak 2004. és 2007. április-május között fordított W-t formáznak, azokból aligha lehet adekvátan tendenciákra következtetni. Fontos következtetés, hogy az országhoz való kötődés átlaga 2007. első és 2007 második adatfelvétele között csökkenő tendenciát mutat, mely csökkenő tendencia megfelel a régiók többsége által mutatott csökkenésnek vagy igen enyhe erősödésnek.

Az országos szinthez való kötődés átlaga szempontjából 2004-ben az utolsó helyen áll a dél-alföldi régió lakossága, míg a második, a 2007-es adatfelvételen az első helyre kerül. A régióban nem csupán az országos kötődés, hanem minden egyes területi szinthez való kötődés esetében erősödés állapítható meg, mely feltehetően a társadalmi kohézió és integráció szintjének erősödését, illetve a régiós kilátások javulását jelzi.

\section{2. ábra - Országhoz kötődés átlaga idősorosan, régiónként (min. 1 - max. 4)}

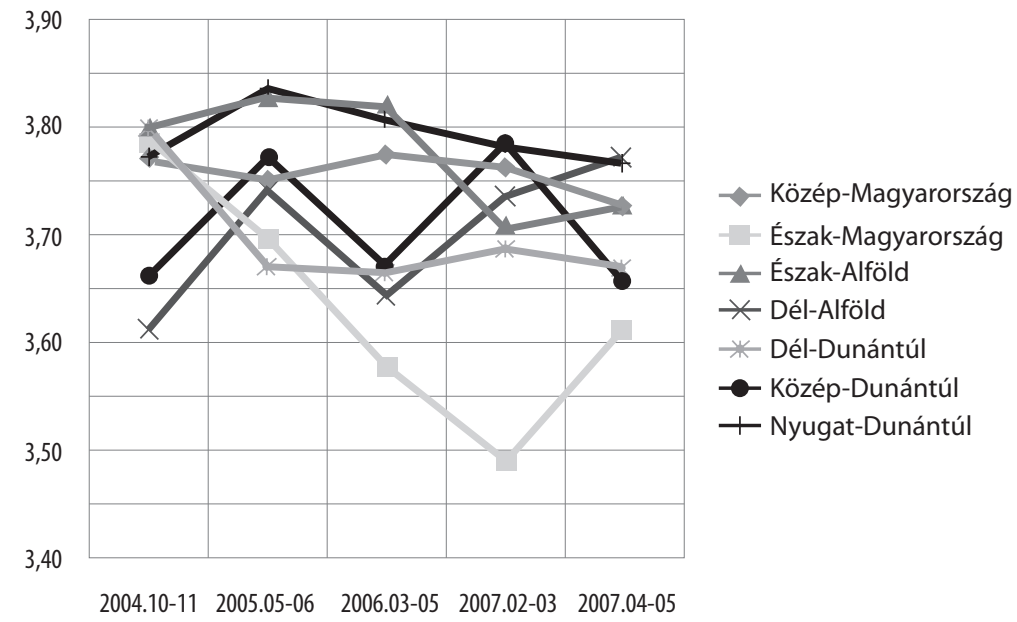

\subsubsection{Európa}

Az Európához való kötődés átlagai a 24-es ábráról olvashatóak le. A 2004-es évben a többi régióval összehasonlítva a dél-dunántúli régió lakossága körében volt a legmagasabb. Ez az átlagérték 2005-re enyhén növekedett, azonban a térség első helyéről így is visszaesett. 2005-ről 2006-ra nagy esés következett be 
a térség lakosainak európai kötődésében, az utolsó helyre estek vissza, majd 2007-re jelentős erősödés következett be, és ismét az első helyre ugrott a régió. A dél-dunántúli lakosság stabil kötődéséről Európa felé aligha beszélhetünk. Az európai kötődés 2006-ról 2007-re történő kirívó mértékű növekedését a „Pécs - Európa Kulturális Fővárosa 2010” projekt sikere, illetve annak kampányai is befolyásolhatták.

Az Európához való kötődés szempontjából 2004-ben második helyen állt a magyar régiók rangsorában a Nyugat-Dunántúl. 2005-re egy igen nagymértékủ emelkedés után a régió lakosságának európai kötődési átlaga az első helyre került. 2006-ra azonban nagymértékü csökkenés zajlott le, de mivel a csökkenő tendencia 2005-ről 2006-ra minden régió esetében általános volt, a térség ebben az évben is megőrizte első helyét a régiós rangsorban. A csökkenő tendencia 2007-re igen kirívóan nagymértékü (19 százados) csökkenéssel folytatódott, és ezzel a Nyugat-Dunántúl a lista sereghajtói közé, az Európához kevésbé kötődő térségek közé került.

Észak-Magyarország folyamatos csökkenő tendenciával 2004-es harmadik helyéről 2007-re az utolsó helyre került. Közép-Magyarország átlaga 2004-ről 2005-re enyhe erősödést, ám ezután 2006-ra nagyobb gyengülést mutatott. 2007re enyhe átlagnövekedéssel a negyedik helyre kerül a térség, ugyanoda, ahonnan 2004-ben indult. Az Észak-Alföld 2004-ről 2005-re erősödő átlaggal javított a régiók közötti pozícióján, ám 2006-ra és 2007-re folyamatos csökkenés következett, a régió lakosságának Európához való kötődése 2007-re az utolsók közé szorult vissza. A Közép-Dunántúl 2004-ről 2007-re a hatodik helyről a harmadikra javított az országos rangsorban, követve azokat a trendeket és tendenciákat, amelyeket a többi régió is.

A dél-alföldi régió lakosságának európai kötődés átlaga 2004-ben az utolsó helyen állt a régiók rangsorában. Ez 2005-re nagymértékben erősödött, majd még nagyobb mértékben csökkent 2006-ra. 2007-re közepes mértékü erősödéssel a régió lakossága a második helyre került. Korábban már írtam a Dél-Alföldön lezajló általános kötődési erősödésről, az Európához való kötődés emelkedése is ezen folyamat részeként értelmezhető. 


\section{3. ábra - Európához kötödés átlaga idősorosan, régiónként (min. 1 - max. 4)}

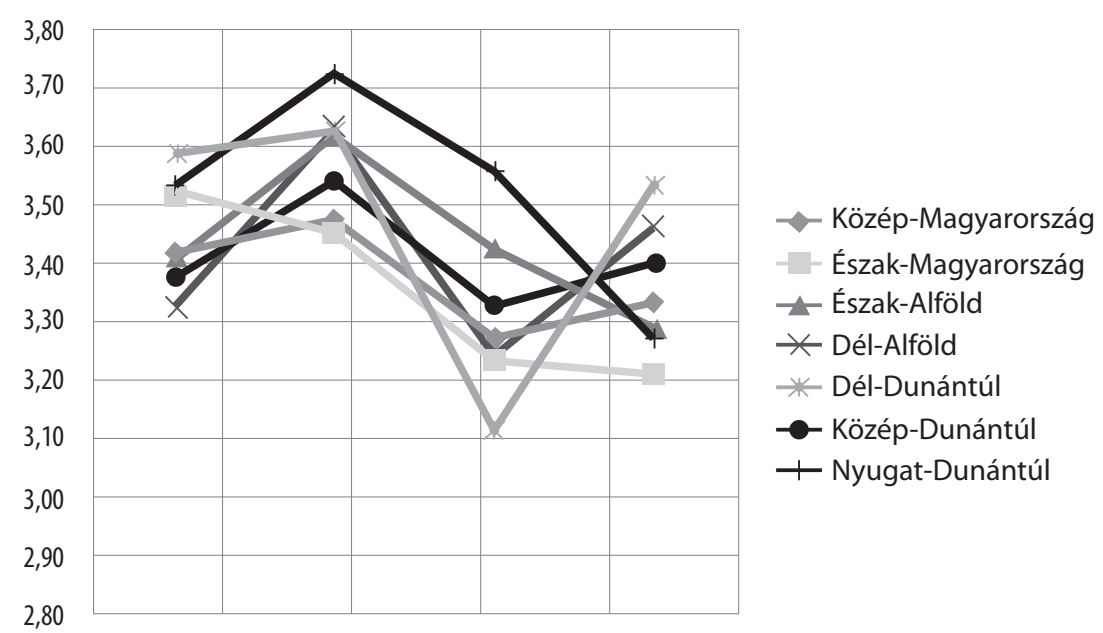

$2004.10-11 \quad 2005.05-06 \quad 2006.03-05 \quad 2007.02-03 \quad 2007.04-05$

\subsection{ORSZÁGOS ÉS REGIONÁLIS KÖTŐDÉSEK}

\subsubsection{Országos adatok}

Az országos minta kötődéseinek vizsgálatakor a 25. ábra alapján egyértelmüen megállapítható, hogy az országhoz, a településhez és a régióhoz való kötődés átlaga idősoros bontásban alig változik, a trendvonalak egyenletesek. Minden egyes felmérésben az országos minta átlagos kötődése az országhoz a legerősebb (3,7 és 3,8 közötti átlag 4-es skálán). Leolvasható, hogy az összes szint közült a legerősebb a kötődés a nemzeti szinthez, mely magas átlagértékével elkülönül a többi kötődési formától. Ezt követi a településhez történő kötődés (3,5 és 3,6 között átlag), valamint a régióhoz való kötődés (3,45 és 3,55 közötti átlag). A két átlag ezekben az esetekben is csupán kis mértékben változik, egyenletes szintet hoz. A településhez kötődés erősségéhez közel áll a régióhoz való kötődés erőssége, ezt indokolja, hogy a két változó a megkérdezettek közvetlen életteréhez történő kötődést méri.

Az Európához kötődés átlaga 2004-ről 2005-re erősödött, ám ezt követően 2006ra és 2007-re nagymértékben csökkent. Az éles növekedéssel majd csökkenéssel egyedül ez a kötődési forma lóg ki tehát a többi kötődéstípus egyenletes trendje közül. A tendencia alátámasztja az eddig tapasztaltakat, miszerint 2005-ben volt a legerősebb az EU-hoz való kötődés szintje, az Euro-optimizmus. Ekkor a kötődésérték 
a többi kötődéssel nagy arányban egybeesett. 2006-ra és 2007-re azonban ez az optimizmus oda lett, és a kötődés szintje 2007-re a 2004-es érték alá csúszott.

\section{4. ábra - Kötődés a területi szintekhez, idősoros átlag, országos adatok (min. 1 - max. 4)}

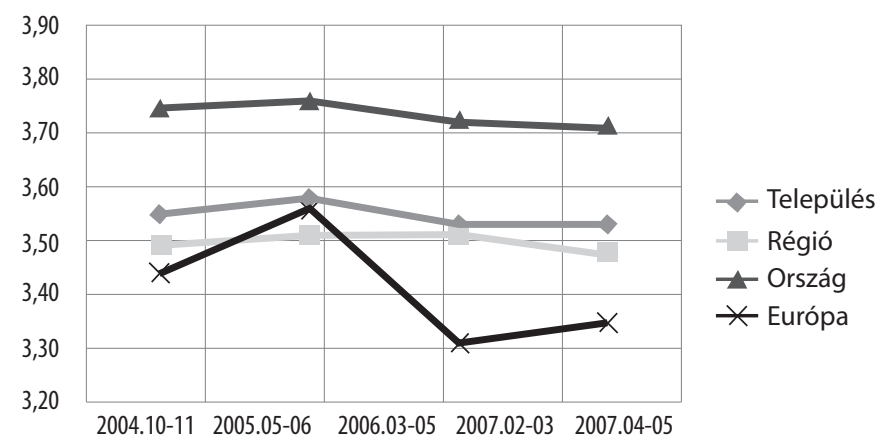

\subsubsection{Közép-Magyarország}

A központi régió kötődési tendenciái (26. ábra) nagymértékben hasonlítanak az országos kötődési tendenciák alakulásához, az egyetlen különbségnek a lokalitás, de főleg a regionalitás felértékelődése tekinthető. A központi régió lakosai is leginkább az országos szinthez kötődnek, mely kötődés egyenletes a különböző vizsgálatok folyamán (3,7 és 3,8 közötti átlag). A második legerősebb kötődést a település iránt érzi a régió lakossága, ám érdekességképpen megemlítendő, hogy 2005-ben ezt a második helyet átvette az Európához történő kötődés. A fővárosi lakosok hagyományos kötődési rendszerében 2005-ben igazán európainak érezték magukat, ám ezen euro-optimista pillanat után a településhez való kötődés visszaállt a második helyre. A településhez való kötődés 2004-ben és 2005-ben nagyjából egy szinten állt, ám 2006-ra és 2007-re megerősödött, amikor szintén nagyjából egy szintre került. A régióhoz való kötődésnél hasonló tendencia figyelhető meg: az érték 2004-ben és 2005-ben nagyjából egy szinten állt, ám 2006-ra megerősödött, és kissé visszaesett, de 2007-ben a kiinduló szintnél még mindig jóval magasabb átlagon állt. A településhez és a régióhoz való kötődés átlagértékeit ábrázoló trendvonalak elmozdulásai közötti hasonlóság szembeötlő. Ezen adatok alapján beszélhetünk a lokalitás és a regionalitás felértékelődéséről. És bár a településhez való kötődés átlaga 2004-ben és 2007-ben egyaránt magasabb, mint a régióhoz kötődés átlaga, nem lehet elvitatni, hogy a két kötődést mérő változó kiinduló pontjához képest jelentős erősödést tudott felmutatni. 
Az európai kötődés mértéke 2004-ben nagyobb volt, mint a régióhoz kötődésé, és 2005-ben nagyobb volt, mint a régióhoz és településhez kötődésé. Ez azonban egy nagy zuhanás következtében 2006-ra megváltozott, amikor is ez a kötődéstípus lett a legkevésbé jelentős az összes közül. 2007-re a kötődéstípus enyhe erősödést tudott mutatni, ám továbbra is a legkevésbé jelentős kötődés az összes közül, és a különbség a következö, regionális kötődés átlagáig több mint egy tized átlagpont.

\section{5. ábra - Kötődés a területi szintekhez, idősoros átlag, Közép-Magyarország (min. 1 - $\max$. 4)}

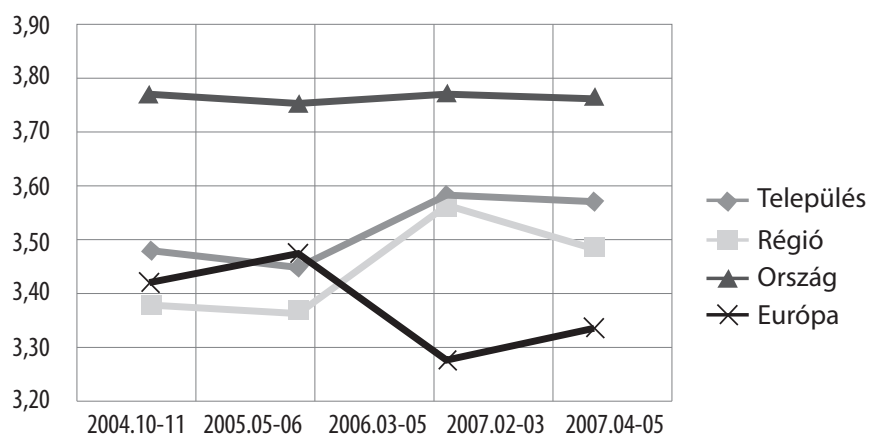

\subsection{3 Észak-Magyarország}

Az észak-magyarországi régió lakosságának kötődései a többi régió kötődési átlagaihoz képest egyedi arculatot mutatnak (27. ábra). A legjellemzőbb tendencia a folyamatos, hegyomlásszerü csökkenés minden kötődéstípus esetében, amely a grafikonon megfigyelhető. A kötődéstípusok együttes, negatív irányú elmozdulása egyfajta bizalomvesztési tendenciát jelez a térség lakossága körében. A régióban elmaradt az eurooptimizmusból euro-pesszimizmusba történő átfordulás, amely a többi vizsgált területi egység esetében előfordult. Ennek oka az eleve rosszabb kiinduló helyzet lehetett, a térség lakossága azonnali megoldást remélt gondjaira az EU csatlakozás után, melynek elodázódása, illetve elmaradása a kötődések gyengülésével járt együtt. Érdekesség ugyanakkor, hogy 2007-ben a második legmagasabb az Európához való kötődés átlaga a lakosság kötődései közül, úgy tünik, az itt élők még számítanak valamilyen európai indíttatású fordulatra az életükben.

A legerősebb, de folyamatosan csökkenő szintet mutató kötődést a nemzeti szinthez érzik a lakosok, a második, szintén erős, de folyamatosan csökkenő és második helyét 2007-ben Európának átadó kötődési forma a településhez kötődés. A régióhoz való 
kötődés a leggyengébb kötődéstípus, 2006 kivételével végig sereghajtó, az itt élő lakosság ezt a területi szintet nem tudta kötődési, identifikálódási rendszerébe internalizálni.

A grafikon tanulsága szerint tehát egyedi kötődési arculatú térségek is léteznek Magyarországon, ilyen az észak-magyarországi régió, ahol azonban a kötődések folyamatosan gyengülnek. Ez hipotézisünk szerint együtt jár a társadalmi kohézió szintjének folyamatos gyengülésével, hiszen a két jelenség hatással van egymásra. A felmerült társadalmi és gazdasági problémák meggyengítették az itt élö lakosság kötődését, identifikálódását lakóhelyük lokális-regionális és országos-európai szintjével. A polgárok számára nehezen perceptálható európai szinthez való kötődés fontosságának 2007-es növekedése pedig jó indikátora a térség helyzetével kapcsolatos lakossági véleményeknek, elgondolásoknak, érzéseknek.

A kérdés csupán az, hogy a további kutatási eredmények elemzésekor ez a kötődési gyengülés vajon folytatódik-e, illetve hogy a folyamat kezelhetö-e valamilyen formában. A kötődés egészséges szintje szükséges a társadalmi kohézió és integráció elemi feltételinek a megteremtődéséhez, és ezen térség esetében a grafikon riasztó tendenciára hívja fel a figyelmünket, mely szakpolitikai beavatkozásért kiállt. Az országhoz való kötődés esetében biztató, hogy a 2007. április-májusában elvégzett adatfelvétel már erősödést mutat, ám a többi kategóriával való összehasonlítás lehetőségének hiánya miatt annak eredményeit ezen a grafikonon nincs módunk ábrázolni.

\section{6. ábra - Kötődés a területi szintekhez, idősoros átlag, Észak-Magyarország (min. 1 - max. 4)}

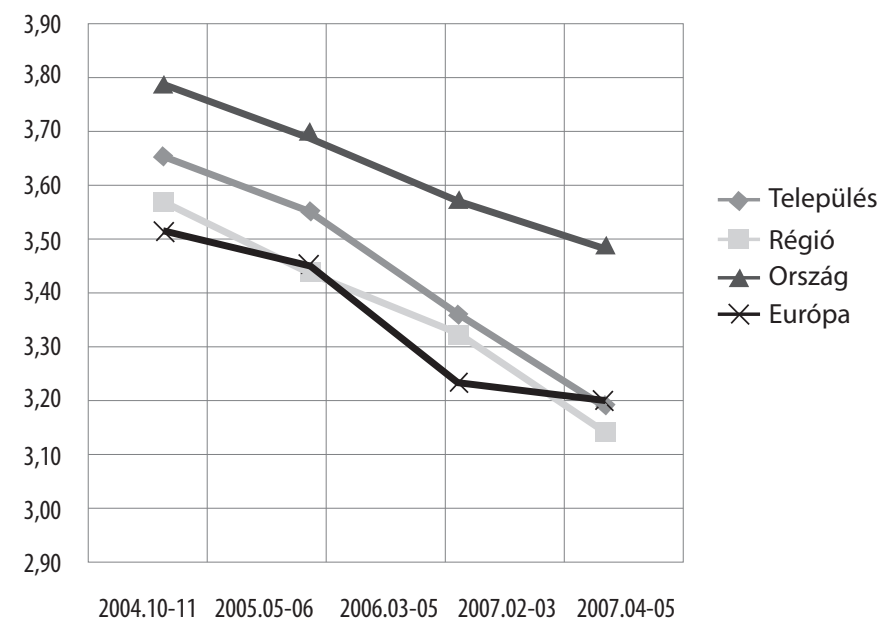




\subsection{4 Észak-Alföld}

Az észak-alföldi lakosság kötődéseinek vizsgálata alapján a hagyományos kötődési struktúrákat láthatjuk kibontakozni a 28. ábrán. A lakosság 2004-ben leginkább az országhoz kötődött, azt követte a település, majd a régió és végül Európa. Ez a sorrend egyben a 2007-es év záró sorrendje is. A köztes időben, 2005-ben azonban a lakosság jobban kötődött Európához, mint a régiójához, 2006-ban pedig a régió fontosságban megelőzte a településhez való kötődést. Az Európához való kötődés átlaga 2005 után folyamatosan gyengül, hogy 2007-ben elérje mélypontját. Érdekesség, hogy 2006-ról 2007-re minden kötődéstípus átlag gyengülést mutatott, amely kedvezőtlen gazdasági, illetve társadalmi folyamatok oka, illetve következménye lehet.

\section{7. ábra-Kötődés a területi szintekhez, idösoros átlag, Észak-Alföld (min. 1 - max. 4)}

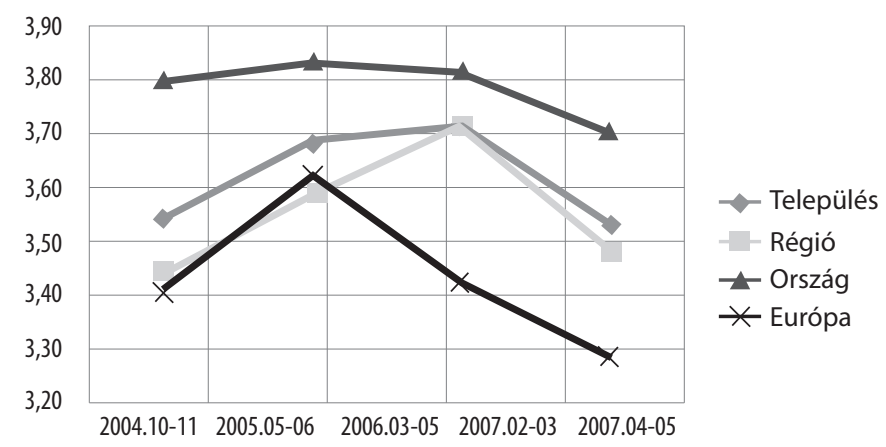

\subsubsection{Dél-Alföld}

A Dél-Alföld adatai a 29. ábráról olvashatóak le. A régió 2004-ben a hagyományos kötődési erősorrendet mutatja: az első az ország, majd azt követi a település, a régió és végül Európa. A dél-alföldi lakosság kötődési átlagai minden egyes időpontból egyfelé mozdultak el: 2004-ről 2005-re erősödtek. Ebben az évben különösen felértékelődött az Európához való kötődés, hiszen átlaga szinte megegyezett a településhez kötődés átlagával. 2005-ről 2006-ra minden kötődési elem csökkent, a legnagyobb mértékben az Európához való kötődés zuhant, vissza az utolsó helyre. 2006-ról 2007-re minden egyes kötődési elem esetében újabb emelkedés 
volt tapasztalható. A legnagyobb mértékben a régióhoz, illetve az Európához való kötődés erősödött, ám nem közelítette meg a konvencionális kötődéseket. A településhez való és az országos kötődés értéke közelített egymáshoz, néhány tizedes holtversennyel foglalják el az első helyet.

\section{8. ábra-Kötödés a területi szintekhez, idősoros átlag, Dél-Alföld (min. 1 - max. 4)}

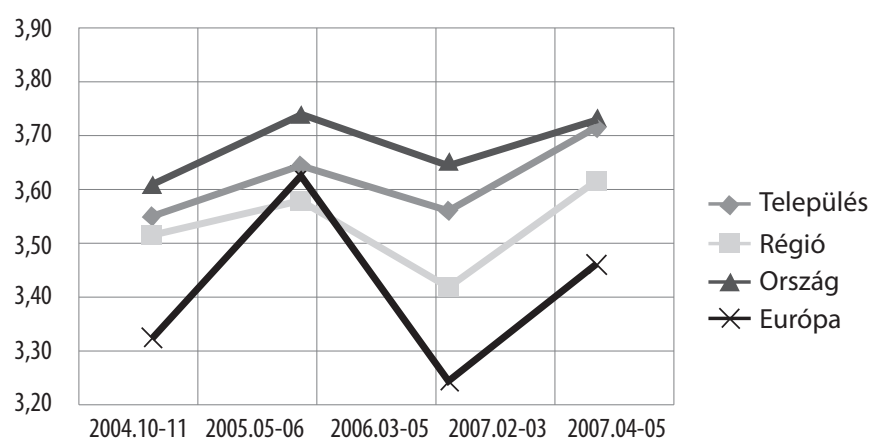

\subsubsection{Dél-Dunántúl}

A dél-dunántúli régió kötődései nem konvencionális képet mutatnak (30. ábra) a többi magyar régióval összehasonlítva. 2004-ben a legfontosabb kötődési pont az ország, majd ezt követi a régió melyet Európa, illetve a település követ. Ez a rangsor 2005-re kissé átrendeződik: a Dél-Dunántúl lakossága leginkább Magyarországhoz, majd pedig Európához kötődik. Ezeket követi sorrendben a régió és a település. 2006-ra minden kötődés esetében csökkenés, az Európához való kötődés esetében zuhanás volt tapasztalható. Az Európához való kötődés 2006ra több mint öt tizeddel, a skála 1/6-ával esett vissza, innen viszont négytizedes emelkedést produkált, és 2007-re erősödött, a régióhoz való kötődéssel közel egy szintre. 2007-ben tehát szinte holtverseny tapasztalható a konvencionális (országos-település) és körülbelül egy tizeddel lemaradva a nem konvencionális (Európa-régió) területi szintek kapcsolatában, természetesen általános erősödés mellett. A Dél-Alföld mellett a Dél-Dunántúl az a régió, ahol 2006-ról 2007-re minden területi kötődés átlag növekedett. 


\section{9. ábra - Kötödés a területi szintekhez, idösoros átlag, Dél-Dunántúl}

(min. 1 - max. 4)

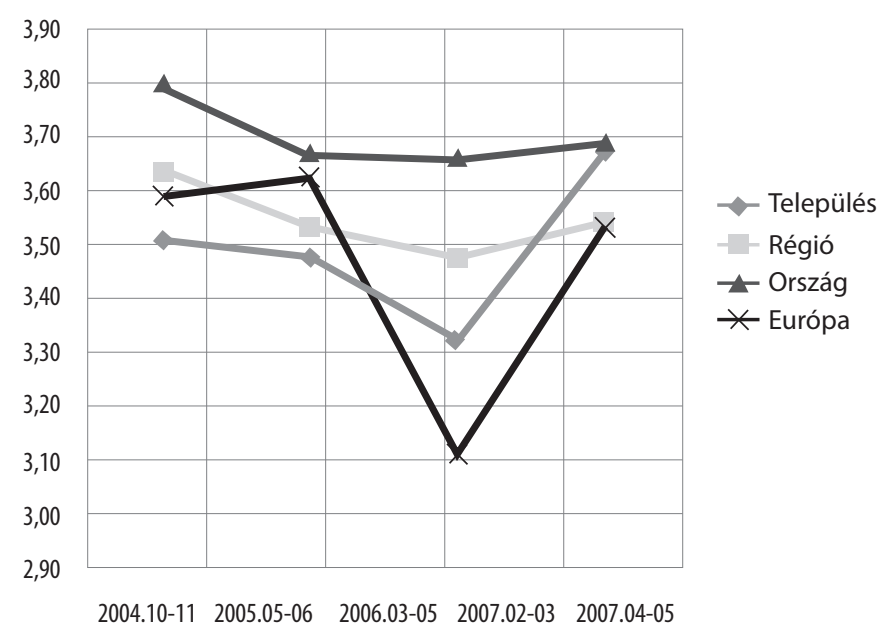

\subsubsection{Közép-Dunántúl}

A régió a kötődés szempontjából (31. ábra) 2004-ben konvencionális képet mutat, amikor is az ország - település - régió - Európa sorrend alakul ki, azonban már ekkor feltünik, hogy a Magyarországhoz való kötődés átlaga közel két tizeddel magasabb, mint az azt követö településhez kötődés átlaga, melyhez azonban ennél lényegesen közelebb esnek nagyságban a régióhoz és Európához való kötődés átlagai. Ez a különbség az országhoz való kötődés és a másik három kötődési típus között minden egyes időpontban fennmarad. Ennek alapján elmondható, hogy az országhoz való kötődés a közép-dunántúli lakosok gondolkodásában elkülönül a másik három kötődési típustól. Változásról lényegében tehát csak ezen három esetében beszélhetünk. 2005-ben az Európához kötődés megelőzte a régióhoz való kötődést, és egy tizedre megközelítette a településhez való kötődés átlagát. 2006ra az Európához kötődés a legtöbb magyar régióban tapasztaltakhoz hasonlóan nagymértékủ esést produkált, visszakerült az utolsó helyre. Ebben az évben a régióhoz való kötődés közelítette meg a településhez kötődés átlagát. 2007-re minden kötődési típus átlaga erősödött, és elmondható, hogy megváltozott a 2004-es konvencionális sorrend, mivel a regionális kötődés nagyobb mértékben erősödött, mint az alig változó településhez kötődés. A régió intézményének felértékelödése mellett tapasztalható az Európához való kötődés erősödése is. 
30. ábra - Kötődés a területi szintekhez, idősoros átlag, Közép-Dunántúl (min. $1-\max$. 4)

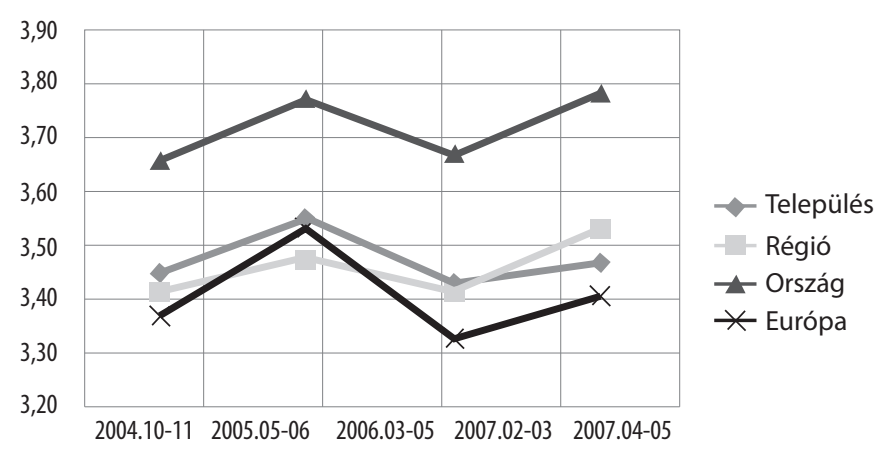

\subsubsection{Nyugat-Dunántúl}

A régióban, 2004-ben szintén a konvencionális kötődési átlag-erősorrend (32. ábra) alakult ki. Jelentős különbség nem volt tapasztalható, egyedül az Európához való kötődés átlaga volt legalább egy tizeddel alacsonyabb, mint a többi kötődési átlag. A 2005-ös adatfelvételi időpontra minden egyes kötődési átlag erősödött, a legnagyobb mértékben az Európához kötődés átlaga, mely így felzárkózott a többi mellé, ám a megőrzött konvencionális struktúrában továbbra is az utolsó helyen állt. 2006-ra minden egyes kötődéstípus gyengült, a legnagyobb mértékben a településhez kötődés. Gyengült a regionális kötődés átlagokat mérő változó is, ám ezt megelőzte a szintén, ám kisebb mértékben gyengülő európai kötődésváltozó. 2007-re az országos és települési kötődés gyengült, a regionális kötődés átlaga stagnált, míg az Európához való kötődés átlaga zuhant. Az új sorrend az országhoz, a régióhoz, a településhez, illetve az Európához való kötődés lett. Az Európához kötődés az ábra 2007-es időpontjában már több mint négy tizeddel alacsonyabb, mint a sorrendben legerősebb országhoz kötődés átlag. 


\section{1. ábra - Kötődés a területi szintekhez, idősoros átlag, Nyugat-Dunántúl}

(min. 1 - max. 4)

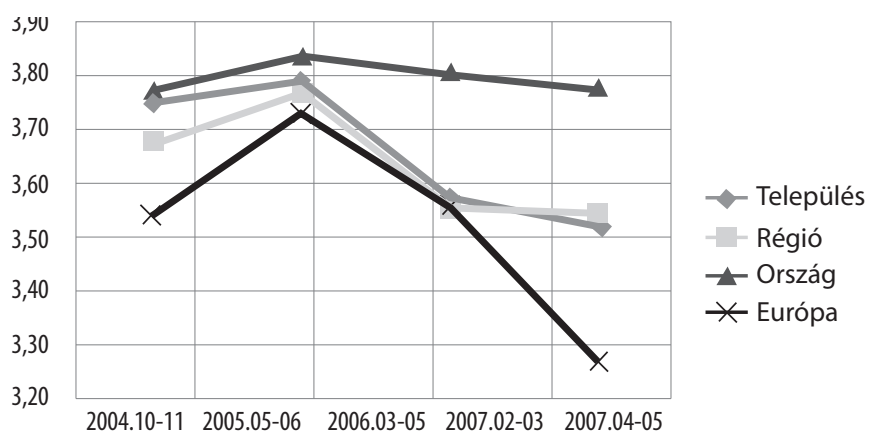

\subsection{TANULSÁGOK}

A területi kötődések elemzésének eredményei azt mutatják, hogy minél inkább távol kerülünk a lokalitás határaitól, az emberek annál kevésbé kötődnek az adott területi szintekhez. Fontos eredmény, hogy a kötődési adatokból kiolvasható az Európai Uniós csatlakozás időszakával járó, európai területi szintekhez való kötődési optimizmus megingása. 2006-ra ez az optimizmus a kötődések visszaesésében megmutatkozva megkopni látszik, ám a kötődések újból felerősödnek 2007-re. Az emberek elöször 2004-ben nagyobb bizalmat fektettek az EU-ba és a gondolkodásukban feltehetően ahhoz kötődő új területi szintekbe, a régiókba. Ez 2006ra visszaesett, ám 2007-re újra felerősödött. A kognitív terek egységességét és a mérési skálák pontosságát vizsgáló Cronbach alfa statisztika is azt igazolta, hogy az emberek egyféleképpen gondolkodtak az Eurobarometer kérdőív által vizsgált összes területi szintről 2004-ben, 2005-ben és 2006-ban. Ez a tendencia azonban 2007-ben megszakadt, a Cronbach alfa az egységes területi rendszerfelfogás végét jelezte. Ezzel összhangban a legtöbb régióban nőtt az Európai Uniós területi szintekhez való kötődés, és néhány térségben egyúttal felértékelödött a konvencionális területi egységekhez való kötődés is. Az alfa statisztika változásának oka föleg az európai szinthez történő kötődés növekedésében és a konvencionális területi kötődések együttes felértékelődésében keresendő. A leírtakat faktorelemzési eljárás segítségével is igazolni tudtuk.

Konklúzióként kijelenthető tehát, hogy a térségek kötődési szintjei általában együtt mozognak. Egy régióban, amennyiben változás tapasztalható a területi 
kötődésben valamelyik vizsgált területi egységhez, akkor általában vele mozdul a többi területi egységhez való kötődése is. Amennyiben a régióban élők területi kötódései stagnálnak, akkor minden területi szint esetében stagnálás lesz megfigyelhető. Ez alól egy markáns kivétel a Nyugat-Dunántúli Régió 2007-ben, ahol a régió lakosainak európai szinthez való kötődései csökkentek, míg a többi kötődésük stagnált.

A társadalmi tőkével való összehasonlítás szempontjából elmondható, hogy a kötődések rövid időn belüli, mérési hibánál nagyobb változásai az azokat vizsgáló elméletek alapján nehezen magyarázhatóak. Ellenben amennyiben a kötődéseket a területi társadalmi tőke részeiként kezeljük a változásokra könnyebben plauzibilis magyarázatokat kaphatunk. 


\section{TERÜLETI KÖTŐDÉS \\ A NAGYVÁROSBAN: EGY ESETTANULMÁNY SZEGEDRŐL}

Ebben a fejezetben egy 2004. év eleji empirikus vizsgálat adatai alapján próbálunk meg képet alkotni a szegedi lakosság térségi kötődéseiröl, egy az Eurobarometer kérdőívekből átemelt kérdéssor segítségével. A kérdésről már szót ejtettünk az Eurobarometer kérdőív alapján írt elemzésünkben ${ }^{23}$. Az ebben az esettanulmányban használt verzió kiegészült egy területi szinttel, a megyével. A kérdés így megpróbálta felderíteni a megkérdezettek kötődését városukhoz, megyéjükhöz, régiójukhoz, országukhoz, illetve az Európai Unióhoz. A kapott adatok alapján azt vizsgáltam, hogy a területi kötődés egyes dimenziói hogyan jelennek meg a szegediek számára, a területi szintek jól elkülönülnek-e gondolati rendszerükben, főként a megyei és regionális szint elkülönülésére fektetve hangsúlyt. A fejezet munkahipotézise az, hogy a szegedi megkérdezettek nem igazán érzik a különbséget a megyei és a régiós területi szintek között, a két egység a gondolkodásukban összemosódik, nincs köztük markáns különbség.

A kérdőíves vizsgálat lekérdezése az Európai Uniós csatlakozás időszakában történt, amelynek pozitív hatása és akkor még kifejezetten pozitív ígéretekkel történő bevezetése torzíthatja az eredményeket. A jelenséget megpróbáljuk többváltozós statisztikai elemzésekkel és a kötődők szociológiai feltérképezésével körüljárni, vizsgálni. Korábbi elemzéseinkhez képest ez a rész további adalékokkal szolgál. A magyar EU csatlakozás után 2007-ig nem szerepelt az EUROBAROMETER kérdőív hullámaiban kérdés a megyei szinthez való kötődéssel kapcsolatban. Ezen munkában lehetőség nyílt a szegedi lakosság megyei kötődésének elemzésére.

23 A különböző térségi szintek jelentéstartalmaival kapcsolatban lásd: 3. tábla. 


\subsection{TERÜLETI KÖTŐDÉS ÉS IDENTITÁS}

Kvantitatív felméréssel gyüjtött, standardizált szociológiai adatokkal területi identitást vizsgálni aligha lehetséges, ahogy ezt már egy korábbi fejezetben megállapítottuk. Ebben az esettanulmányban a területi kötődést a területi identitás elemének tekintjük, és vizsgálatát statisztikai elemzéssel végezzük el.

Bugovics Zoltán 2004-es tanulmányában hozzánk hasonlóan az identitás és a térkategóriák összefüggéseit vizsgálta. Alapvetően hasonló eredményre jutott, mint én, az országos és lokális identitás-kötődés a legerősebb, az Európai identitás kifejezetten gyenge, a megyei identitás-kötődés relatíve erős, a regionális viszont lényegesen alacsonyabb vizsgálatában. A Bugovics által elemzett adatfelvételben nem található meg az a hasonlóság a megyei és a regionális szint között, mint a 2004-es Szeged Studies adatai esetében (Bugovics 2004, 69 o.).

Mivel a vizsgált terület és az időszak jelen mủ esetében más, ezt a különbséget nem szabad túlértékelni, de mégis adódik egy olyan értelmezési lehetőség, hogy a hazai lakosságot az EU csatlakozást megelőző információáradat - müvi úton jobban kötődővé tette a regionális szinthez, viszont az emberek nincsenek tisztában a különbséggel a régiós és a megyei szintek között.

\subsection{KÖTŐDÉS A KÜLÖNBÖZŐ TERÜLETI SZINTEKHEZ}

Az 12. táblázatban láthatjuk a megkérdezettek területi kötődéseire vonatkozó adatokat. Kitünik, hogy a megkérdezettek 77 százaléka (N=1073) vallotta, hogy erősen kötődik Magyarországhoz, és 67 százalék ( $N=1074)$, hogy erősen kötődik Szeged városhoz. Egyaránt 48 százalék $(\mathrm{N}=1073)$ mondta, hogy erősen kötődik a Dél-Alföldi Régióhoz, illetve Csongrád megyéhez. Ezen kérdések esetében szinte minden megkérdezett választ adott. Az Európai Unióhoz való kötődés esetében a válaszadók száma már csak 890 , az erős kötődők aránya pedig 28 százalék. Az adatfelvétel hazánk EU csatlakozása elött néhány hónappal zajlott, s az tünik ki belőle, hogy a megkérdezettek akkor még „nem érezték teljes mértékben magukénak" az Európai Uniót. 
12. tábla - A szegediek kötődései a területi szintekhez

\begin{tabular}{|c|c|c|c|}
\hline Szeged városhoz mennyire kötődik? & $\%$ & $\begin{array}{l}\text { Magyarországhoz mennyire kötő- } \\
\text { dik? }\end{array}$ & $\%$ \\
\hline 1. Egyáltalán nem kötődik & 1,0 & 1. Egyáltalán nem kötődik & 1,1 \\
\hline 2. Inkább nem kötődik & 4,5 & 2. Inkább nem kötődik & 3,6 \\
\hline 3. Inkább kötődik & 26,9 & 3. Inkább kötődik & 18,3 \\
\hline 4. Erősen kötődik & 67,6 & 4. Erősen kötődik & 77,0 \\
\hline $\mathrm{N}$ & 1074 & $\mathrm{~N}$ & 1073 \\
\hline $\begin{array}{l}\text { Csongrád megyéhez mennyire kötő- } \\
\text { dik? }\end{array}$ & $\%$ & $\begin{array}{l}\text { Az Európai Unióhoz mennyire } \\
\text { kötődik? }\end{array}$ & $\%$ \\
\hline 1. Egyáltalán nem kötődik & 6,4 & 1. Egyáltalán nem kötődik & 15,0 \\
\hline 2. Inkább nem kötődik & 13,2 & 2. Inkább nem kötődik & 17,5 \\
\hline 3. Inkább kötődik & 31,7 & 3. Inkább kötődik & 39,3 \\
\hline 4. Erősen kötődik & 48,7 & 4. Erősen kötődik & 28,2 \\
\hline $\mathrm{N}$ & 1073 & $\mathrm{~N}$ & 890 \\
\hline $\begin{array}{l}\text { A Dél-Alföldi Régióhoz mennyire } \\
\text { kötődik? }\end{array}$ & $\%$ & & \\
\hline 1. Egyáltalán nem kötődik & 5,5 & & \\
\hline 2. Inkább nem kötődik & 13,8 & & \\
\hline 3. Inkább kötődik & 32,5 & & \\
\hline 4. Erősen kötődik & 48,2 & & \\
\hline $\mathrm{N}$ & 1073 & & \\
\hline
\end{tabular}

Adatainkból kitünik, hogy a szegedi lakosság Magyarországhoz és városához kötődik a legerősebben, és a megkérdezettek majdnem fele vall be erős kötődést megyéje és régiója iránt. Ha a regionális és megyei kötődés szempontjából a teljes adatsort vesszük figyelembe, láthatjuk, hogy a kapott válaszarányok szinte minden válaszkategóriában nagyon hasonlóan alakulnak. A nagyvárosi minta így egyértelmüen nagyon hasonlóan fogta fel a területi középszint két elemét, a megyei és a regionális szinteket. A továbbiakban arra keressük a választ, hogy a megkérdezettek válaszai miért mutatnak ilyetén nagyfokú hasonlóságot a megyei és a regionális kötődésük esetében. 


\subsection{FAKTORELEMZÉS AZ ÖT KÖTŐDÉST VIZSGÁLÓ VÁLTOZÓRA}

Az exploratív faktorelemzés módszere a változók mögötti látens dimenziók feltárására használható adatredukciós eljárás. Ebben a kutatásban az elvégzett exploratív faktorelemzések minden esetben a maximum likelihood módszerével, varimax rotációval készülnek. A modellek ellenőrzése végett mindegyik eljárásba bevettük a KMO-Bartlett tesztet, amelyből a modell érvényességére kaphatunk statisztikai visszaigazolást.

Az öt különböző területi szintre vonatkozó faktorelemzés eredményeként azt kívánjuk megkapni, hogy a megkérdezettek gondolkodásában azok hogyan különülnek el, mely szintek kerülnek egy faktorra. Feltételezzük, hogy a hasonló válaszok miatt a regionális és megyei szint egy faktoron fog elhelyezkedni, markánsan elkülönülve a többi területi szinttöl.

Az első faktorelemzésbe bevettük mind az öt változót, a modell megfelelönek bizonyult, viszont sérült a faktorelemzés egyik hüvelykujj-szabálya, az EU-ra vonatkozó változó eredeti információtartalmának csupán 2\%-át tudta megőrizni, szemben a minimális $25 \%$-al. Ezért azt mondhatjuk, hogy ez a területi szint „kilóg” ebből a faktormodellből, ezáltal már statisztikailag is igazolva következtetésünket, miszerint a szint nem szilárdult még meg a csongrádi megyeszékhely lakosainak gondolkodásában 2004-ben. Következő elemzésünket e változó kihagyásával hajtottuk végre.

Az elemzésbe ebben az esetben négy változó került be, és a megőrzött információtartalom három változó esetében megfelelö, a Magyarországhoz való kötődés változó azonban csak 21\%-ot tudott megőrizni, ami szintén sérti a hüvelykujj-szabályt. Az eredeti faktor mátrixban a változók egy faktoron ülnek, különböző faktorsúlyokkal. A megyei és regionális kötődés faktorsúlya a 13. táblázatban látható, 0,874 illetve 0,848 . 
13. tábla - Kötődési Faktor mátrix

\begin{tabular}{|l|l|}
\hline & $\begin{array}{l}\text { Fak- } \\
\text { tor }\end{array}$ \\
\hline Szeged városhoz mennyire kötődik? & 1 \\
\hline Csongrád megyéhez mennyire kötődik? &, 638 \\
\hline Dél-Alföldi Régióhoz mennyire kötődik? &, 874 \\
\hline Magyarországhoz mennyire kötődik? &, 848 \\
\hline
\end{tabular}

Módszer: Maximum Likelihood.

A faktorelemzéssel a 4 változóból egy faktort tudtunk kibontani, négy iteráció elvégzésével is ugyanez maradt az eredmény. További változók kivétele a modellből már a statisztika szabályai miatt nem lehetséges.

A kapott faktor mátrix alapján elmondhatjuk, hogy egyetlen faktort kaptunk, amit nevezzünk ,területi kötődésnek”. A faktorról kilóg a Magyarországhoz való kötődés, egyértelmüen nem itt lenne a helye, illetve az amúgy erős szegedi kötődés is alacsonyabb súllyal helyezkedik el rajta. Ebből arra következtethetünk, hogy a faktoron a területi középszinthez való kötődést modelleztük, melyből kilóg az országos szint, illetve a nagyváros szintje nem tartozik teljes súllyal ide. A megyei és regionális szint azonban igen, mutatja ezt a hasonlóan magas faktorsúly, amit birtokolnak.

A faktorelemzés tehát elsősorban abban volt segítségünkre, hogy megállapíthassuk, a megye és a régió kötődés tekintetében külön gondolati dimenziót képvisel, elkülönül az EU-tól és az országtól, illetve bár matematikai statisztikai alapon egy dimenzióra fért velük a települési kötődés, de lényegesen alacsonyabb faktorsúllyal. Ebből arra következtethetünk, hogy az emberek hasonlóan gondolkodnak a megyéről és a régióról, és elkülönítik azokat a többi dimenziótól, kivéve a nagyvárost. További következtetésként vonható le, és igazoltnak tekinthető az az elméleti állítás, miszerint a középszint „lebeg” ebben az időszakban a magyar területi struktúrában, és a hozzá való identifikálódást teljesen más tényezők alakítják, mint a megszokott térségi szintekhez történőt. 


\subsection{KLASZTERELEMZÉS A MEGYEI ÉS REGIONÁLIS KÖTŐDÉS VÁLTOZÓIRA}

Miután a látens dimenziók elkülönítésével nem jártunk sikerrel, klaszterelemzést végeztünk a megyei és regionális kötődés változóira, annak érdekében, hogy relatíve homogén csoportokat különítsünk el a kötődés tekintetében. Az eljárás módszeréül a K-Means cluster módszert választottuk. Két klasztert kaptunk, melyek bemutatják, hogy a megkérdezettek két csoportba tömörültek a két változó mentén, az első csoportba kerültek az erősen kötődőhöz húzó válaszadók, a másodikba az inkább nem kötődőhöz húzó válaszadók. A két változó a klaszterelemzés esetében is hasonlóan viselkedett, itt sem tapasztaltunk markáns különbséget köztük.

\subsection{MEGYEI ÉS REGIONÁLIS KÖTŐDÉS DEMOGRÁFIAI BONTÁSBAN}

A következőkben demográfiai bontásban vizsgáljuk a megkérdezetteket a megyéhez, illetve a régióhoz való kötődésük szerint, és eltéréseket keresünk a csoportok között nem, iskolai végzettség és életkor tekintetében. Előzőleg megállapítottuk, hogy 456 megkérdezett vallotta, erősen kötődik a régióhoz és a megyéhez egyaránt, 44 megkérdezett mondta, hogy inkább kötődik a megyéhez, és erősen kötődik a régióhoz, valamint 49 megkérdezett vallotta, hogy erősen kötődik a megyéhez, és inkább kötődik a régióhoz. A különbség nem tünik jelentősnek, a demográfiai változók mentén mégis érdemes végigmenni.

\subsubsection{Kötődés nemek szerint}

Az alábbi 14. és 15. táblázatokban a megyéhez és régióhoz való kötődést láthatjuk nemek szerinti bontásban. Mintánkban többségben voltak a nők, ez a táblázatok adataiból egyértelmüen kitünik. 


\section{4. tábla-megyéhez kötődés nemek szerint}

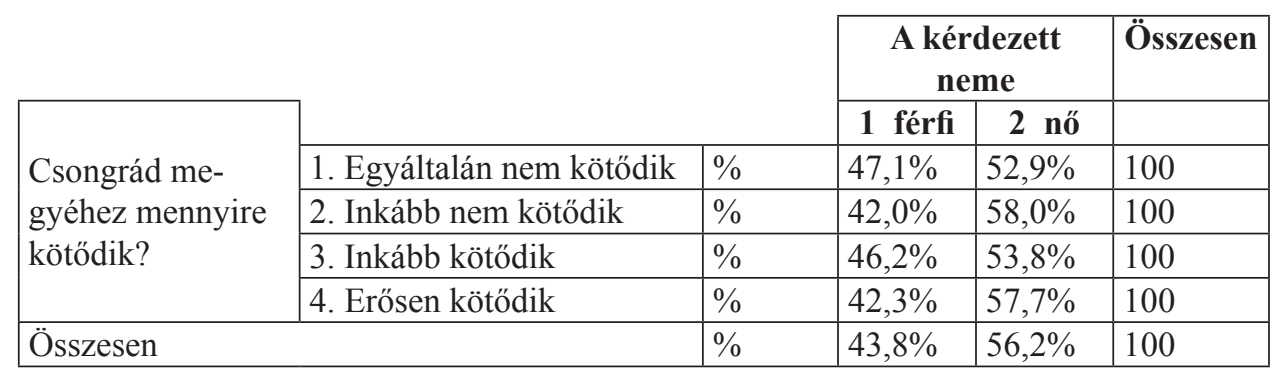

$N=1073$

\section{5. tábla - régióhoz kötődés nemek szerint}

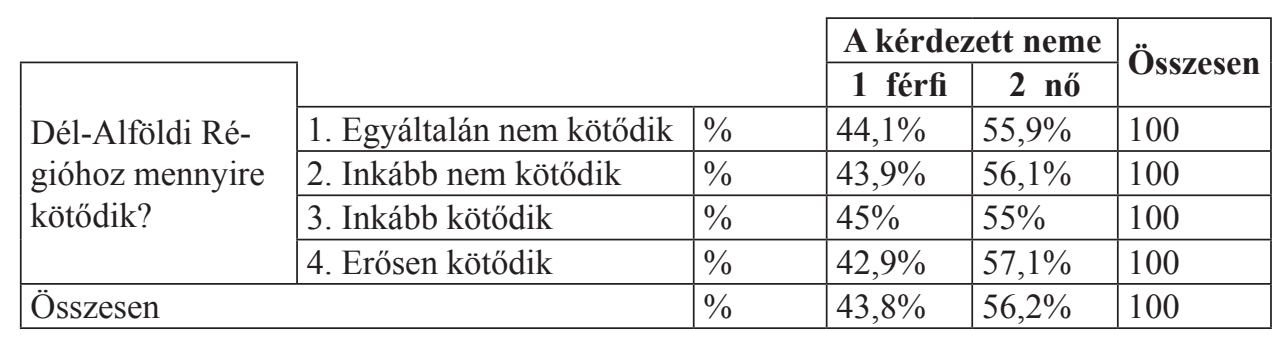

$N=1073$

Jelentős különbséget a táblázatok adatait összevetve sem tudunk leolvasni, a nemek kötődése nagyjából egyenletes. A nemek a fenti adatok szerint $\mathrm{n}$ agyon hasonlóan, majdnem ugyanúgy kezelik a megyét és a régiót kötődés szempontjából.

\subsubsection{Kötődés iskolai végzettség szerint}

Az alábbi - 16. és 17. - táblázatban a megyéhez és régióhoz való kötődést vizsgálhatjuk meg az iskolai végzettséggel összevetve. Az iskolai végzettséget három kategóriára osztottuk, alap- közép- és felső kategóriákra.

A táblázatok adataiból kitűnik, hogy a megyéhez és a régióhoz egyáltalán nem kötődők 48,5, illetve 46,7 százaléka rendelkezik felsőfokú végzettséggel. Ezzel együtt elmondható, hogy az inkább kötődők és az erősen kötődők között - mindkét területi egység esetében - arányukban kevesebben vannak a felsőfokú végzettségűek. Az inkább nem kötődőknél a megye esetében a felsőfokú végzettségüek 
aránya $42,7 \%$, a régió esetében $32,2 \%$. Ez a táblában szereplő legmarkánsabb különbség.

\section{6. tábla - megyéhez kötődés iskolai végzettség szerint}

\begin{tabular}{|c|c|c|c|c|c|c|}
\hline & & & \multicolumn{3}{|c|}{\begin{tabular}{|c|}
$\begin{array}{c}\text { Legmagasabb befejezett iskolai végzettség } \\
\text { kategóriák (3) }\end{array}$ \\
\end{tabular}} & \multirow[b]{2}{*}{ Összesen } \\
\hline & & & $\begin{array}{c}\text { Alapfok } \\
\text { (érettségi } \\
\text { alatt) }\end{array}$ & $\begin{array}{l}\text { Középfok } \\
\text { (érettségi) }\end{array}$ & $\begin{array}{c}\text { Felsőfok } \\
\text { diploma) }\end{array}$ & \\
\hline \multirow{4}{*}{$\begin{array}{l}\text { Csongrád } \\
\text { megyéhez } \\
\text { mennyire } \\
\text { kötődik? }\end{array}$} & $\begin{array}{l}\text { 1. Egyáltalán nem } \\
\text { kötődik }\end{array}$ & $\%$ & $14,7 \%$ & $36,8 \%$ & $48,5 \%$ & 100 \\
\hline & $\begin{array}{l}\text { 2. Inkább nem } \\
\text { kötődik }\end{array}$ & $\%$ & $19,6 \%$ & $37,8 \%$ & $42,7 \%$ & 100 \\
\hline & 3. Inkább kötődik & $\%$ & $33,5 \%$ & $40,0 \%$ & $26,5 \%$ & 100 \\
\hline & 4. Erősen kötődik & $\%$ & $42,3 \%$ & $35,1 \%$ & $22,6 \%$ & 100 \\
\hline \multicolumn{2}{|l|}{ Összesen } & $\%$ & $34,8 \%$ & $37,1 \%$ & $28,1 \%$ & 100 \\
\hline
\end{tabular}

$$
N=1073
$$

\section{7. tábla - régióhoz kötődés iskolai végzettség szerint}

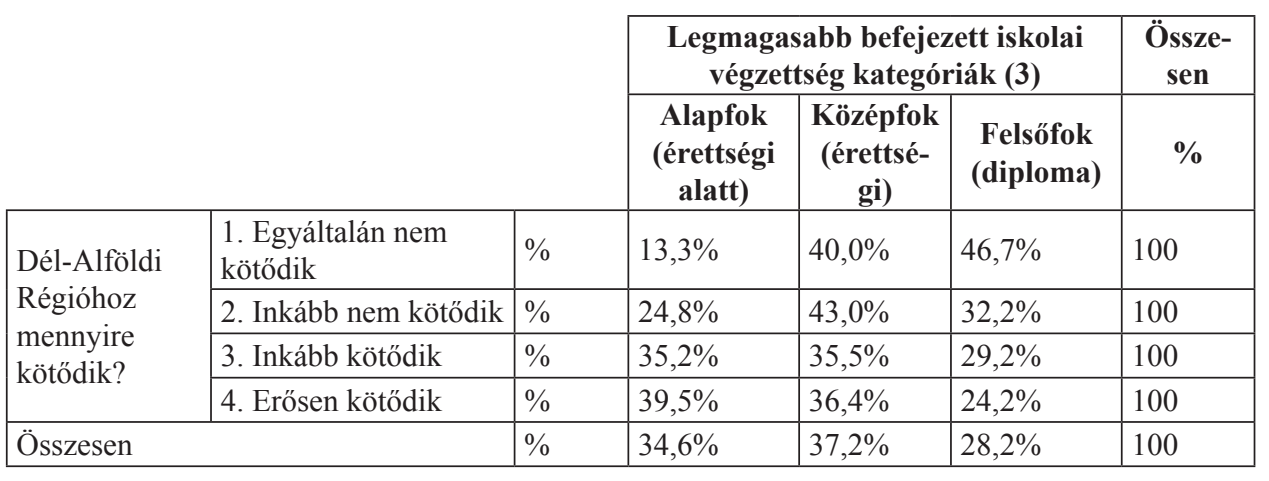

$$
N=1075
$$

Az alapfokú iskolai végzettségüek az erősen kötődők között mindkét területi egység esetében relatív többségben vannak. Itt talán húzható egy halvány választóvonal, láthatjuk, hogy az alapfokú végzettségüek és a középfokú végzettségüek kötődése jelentősebb és erősebb, mint a felsőfokú végzettségüeké mindkét területi egység esetében. 


\subsubsection{Kötődés életkor szerint}

A 18. és 19. táblázatokban életkori csoportok bontásában jelenítettük meg a különböző fokú kötődéseket.

18. tábla - megyéhez kötődés életkor szerint

\begin{tabular}{|c|c|c|c|c|c|c|c|}
\hline & & \multicolumn{4}{|c|}{ Életkor kategóriák (4) } & \multirow[b]{2}{*}{ Összesen } \\
\hline & & & $\begin{array}{c}18-34 \\
\text { éves }\end{array}$ & $\begin{array}{c}35-51 \\
\text { éves }\end{array}$ & $\begin{array}{c}52-64 \\
\text { éves }\end{array}$ & \begin{tabular}{|c|}
$65-$ \\
96 \\
éves
\end{tabular} & \\
\hline \multirow{4}{*}{$\begin{array}{l}\text { Csongrád megyéhez } \\
\text { mennyire kötődik? }\end{array}$} & $\begin{array}{l}\text { 1. Egyál- } \\
\text { talán nem } \\
\text { kötődik }\end{array}$ & $\%$ & 55,9 & 26,5 & 11,8 & 5,9 & 100 \\
\hline & $\begin{array}{l}\text { 2. Inkább } \\
\text { nem kötődik }\end{array}$ & $\%$ & 42,6 & 27,7 & 19,9 & 9,9 & 100 \\
\hline & $\begin{array}{l}\text { 3. Inkább } \\
\text { kötődik }\end{array}$ & $\%$ & 39,9 & 28,2 & 22,0 & 10,0 & 100 \\
\hline & $\begin{array}{l}\text { 4. Erősen } \\
\text { kötődik }\end{array}$ & $\%$ & 20,7 & 31,0 & 29,3 & 19,0 & 100 \\
\hline \multicolumn{2}{|l|}{ Összesen } & $\%$ & 31,9 & 29,4 & 24,6 & 14,1 & 100 \\
\hline
\end{tabular}

$N=1072$

19. tábla - régióhoz kötődés életkor szerint

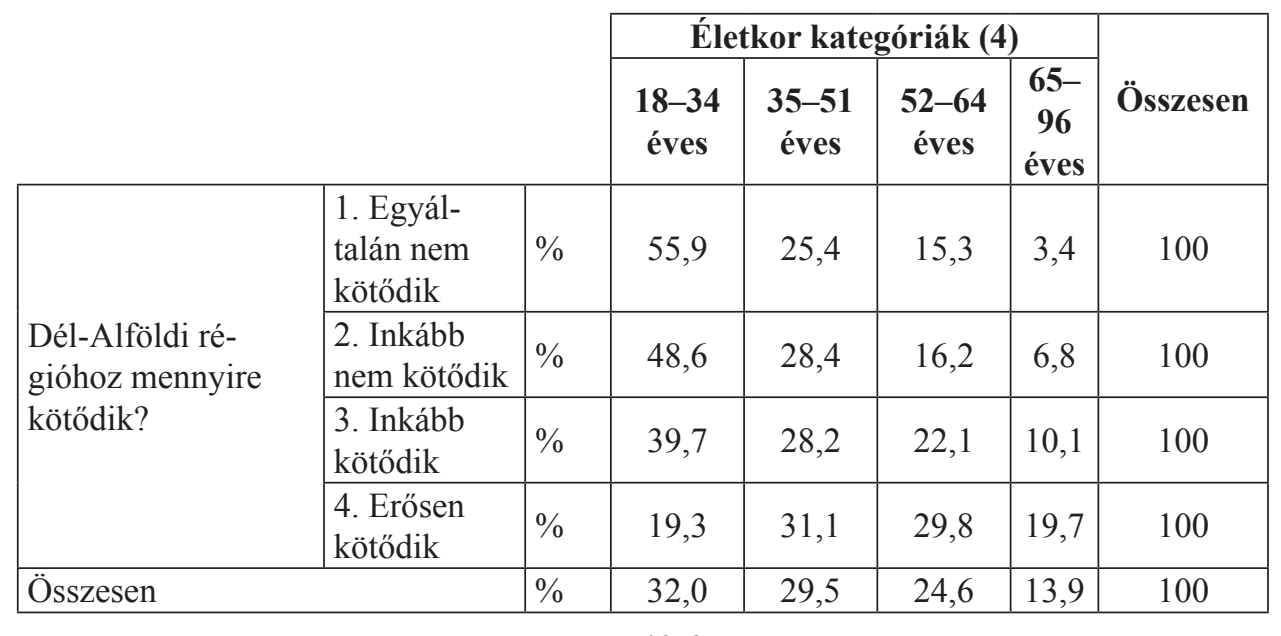

$N=1072$ 
A fenti két táblázatban (18. és 19. tábla) megfigyelhetjük, hogy az idősebbek (5264 éves, 65-96 éves) kötődése a megyei és regionális szint esetében is erősebb, mint a fiataloké (18-34 éves). Ezeket az adatokat összevetve a fentebbi, iskolai végzettségre vonatkozó adatainkkal azt mondhatjuk, hogy a fiatalabb, iskolázottabb réteg kevésbé kötődik a megyéhez és a régióhoz, mint idősebb, alacsonyabb iskolai végzettségü társaik.

\subsubsection{Ordinális korreláció a két változó között}

Eddigi vizsgálódásaink alapján egy további statisztikai elemzéssel kívánjuk alátámasztani feltevésünket, melyben azt állítjuk, hogy az emberek gondolkodásában nem különül el a régió és a megye fogalma a kötődés szempontjából. Ordinális (sorrendi, alacsony) mérési szintű Spearman Rhó korrelációt végeztünk a kötődést mérő változókra, a 20. táblázatban megjelenítettük a megyei és régiós kötődést tartalmazó változókra vonatkozó adatokat.

\section{0. tábla - Korreláció a megyei és regionális kötődésre (Spearman Rhó)}

\begin{tabular}{|c|c|c|}
\hline Spearman Ró & $\begin{array}{c}\text { Dél-alföldi régi- } \\
\text { óhoz mennyire } \\
\text { kötődik? }\end{array}$ \\
\hline $\begin{array}{c}\text { Csongrád megyéhez } \\
\text { mennyire kötődik? }\end{array}$ & Korrelációs együttható &, $759(* *)$ \\
\cline { 2 - 3 } & Szignifikancia & 0,000 \\
\cline { 2 - 3 } & $\mathrm{N}$ & 1017 \\
\hline \multirow{2}{*}{$* *$ A korreláció szignifikáns }
\end{tabular}

A megyéhez és a régióhoz kötődést mérö két változó között szignifikáns, erős öszszefüggést találtunk, mely alátámasztja eddigi feltevésünket a tekintetben, hogy statisztikai összefüggés, majdnem azonosság létezik köztük. Minden változóhoz korreláltunk minden más változóval is, ebből kijött a kötődések sorrendje. Az EUhoz való kötődés bár szignifikáns, de nem jelentős korrelációval bír a két vizsgált változó felé, a Magyarországhoz kötődés korrelációja is szignifikáns, de gyenge 
statisztikai kapcsolatot tár fel. A két változó közepes erejü korrelációt mutat a Szegedhez való kötődés változójával.

\subsection{TANULSÁGOK}

Fejezetünk elején azt tüztük ki célul, hogy megvizsgáljuk a szegediek kötődéseit a különbözö területi szintekhez. Vizsgálatunk során furcsa jelenségre bukkantunk: az Eurobarométer kérdőíves vizsgálatból átvett, identitást, kötődést vizsgáló, a „megye” területi szinttel kiegészített kérdéseinkre a szegedi megkérdezettek meglehetősen hasonló válaszokat adtak a két területi középszintű egység, a megye és a régió esetében. Ebből arra következtettünk, hogy a megkérdezettek nem igazán tudtak különbséget tenni közöttük, a két szint gondolkodásukban nem különül el. Oláh Miklós egy tanulmányában azt írja, hogy a régió fogalmat használja, azonban az nem esik egybe a törvény illetve szabályozás által használt egyik területi egységgel (kistérség, megye, régió) sem, hanem szerves, önálló területi egység. Az Oláh-féle definíció azt támasztja alá, hogy a régió kifejezés mentális tartalma a szegedi válaszadók esetében megalapozottan lehet hasonló a megye kifejezés mentális tartalmához (Oláh, 2002).

A kérdés részletes statisztikai vizsgálata után azt mondhatjuk, hogy bár a szegedi megkérdezettek válaszaiban bizonyos háttérváltozók mentén felfedezhettünk eltéréseket, a két szint esetében ezek az eltérések hasonlóak voltak -a két változó még ebben a metszetben is szinte ugyanazokat az eredményeket hozta. Ennek alapján igazolhatónak vélem az elméleti részben megfogalmazott tézist, miszerint a regionális reformok keretében a régiós szint a megyei szintre lett rátelepítve, és az EU csatlakozás körüli eufória időszakában (például amikor a jelen empirikus kutatás készült) a hagyományos kötődések összekeveredtek az európai kötődésekkel. Ez empirikusan is tapasztalható a megyei és regionális kötődések jelen fejezetben történt összehasonlító vizsgálatának eredményei által.

Az esettanulmány eredményei alapján megállapíthatjuk továbbá, hogy a középszint egységeihez inkább erősebben kötődtek az alacsonyabb iskolai végzettségüek és az idősek, mint a nem kötődő magas iskolai végzettségüek és a fiatalok. Nem alapján igazolható lényeges eltéréseket nem találtunk a szegedi minta esetében. 


\section{A TÁRSADALMI TŐKE ÉS A VALLÁS -ESETTANULMÁNY}

Ebben a fejezetben a vallás és a társadalmi tőke viszonyát vizsgálom elméleti esettanulmány formájában. Elgondolásom szerint sok országban, például az Egyesült Államokban, sok Dél-amerikai országban, az ortodox kelet és dél-európai országokban, illetve például a Katolikus Lengyelországban, Horvátországban és Írországban a vallás a társadalmi tőke egyik legfontosabb, meghatározó dimenziója. Ebbe az írásba mégsem került be a társadalmi tökét bemutató fejezet pontjai közé. Ennek oka egy koncepcionális ok: Magyarországon a legfrissebb kutatások szerint is hanyatlóban van az intézményes vallásosság. A szekularizáció, vagyis a (keresztény) egyház társadalmi és kulturális jelentőségének hanyatlása, elhalványulása a modern társadalmakban (Lechner 2003) megállíthatlan világjelenség. A szekularizáció tekintetében három fő terület különíthető el, melyekre e jelenség alapvető hatással van: a vallásos hit és a vallásgyakorlás hanyatlása; a vallás privatizációja, azaz a magánéletbe való visszaszorulása - de leglábbis iránymutató funkciójának elvesztése; valamint a világi szférák differenciációja (állam, gazdaság, tudomány), azaz a korábbi közös, vallásos világkép alóli kilépése (Casanova 2006). A vallás egyre inkább elveszíti társadalmi intézmény-jellegét és kulturális formává alakul: a vallásosság megnyilvánulásai megmaradtak ugyan a második világháborút követő társadalmi-technikai fejlődés dacára is, ám a vallás már nem irányító, elv (Beckford 1989). Mások szerint a szekularizáció a modern életvitellel lépést tartani képtelen, abból kikopó, vagy éppen elvilágiasodó, s ezért univerzális problémákra választ nem adó vallásosság hanyatlása, mellyel párhuzamosan új tanok, szekták, kultuszok ébredése tapasztalható, mert az embernek mindig lesznek olyan vágyai, melyek csakis transzcendens bevonásával közelíthetők meg (Stark és Brainbridge 1985). Magyarországi viszonylatban hasonló véleménnyel van Tomka Miklós is, aki szerint a szekularizáció, mint a modern társadalmak fenyegető elvallástalanodásának elmélete újragondolandó, mert bár a központosított 
vallási intézmény szerepe, befolyása valóban csökkent a zsidó-keresztény kultúrkörben, s nagy mértéket öltött a vallástalanok aránya, ugyanakkor a vallási kisközösségek burjánzásának is tanúi lehettünk úgy a 90-es évek Magyarországán, mint világviszonylatban (Tomka 1996). Harrach Gábor a szekularizáció statisztikai alapú definícióját adja, mely szerint e fogalmat a felekezeti hovatartozásukat megvallók arányának csökkenése, illetve a vallástalanok és a rejtőzködők arányának növekedése magyarázza meg.

Az elmúlt évtized népszámlálási adatainak tükrében az így felfogtt szekularizáció nagyonis létező jelenség, minthogy a 2001-es és a 2011-es adatok tükrében elmondható, hogy a történelmi egyházak híveinek száma jelentősen csökkent, míg a vallástalanok és a rejtőzködők aránya egy évtized leforgása alatt jelenősen nőtt. Annak ellenére, hogy a lakosság még mindig jelentős hányada 2011-ben valamilyen felekezethez tartozónak mondta magát, az egy évtized alatti változást bemutató adatok rendkívül beszédesek. Az önmgukat katolikusként definiálók aránya a 2001-ben mért 54,5 százalékról 2011-re 38,9 százalékra apadt. A reformátusok népességben képviselt 2001-ben mért 15,9 százalékos aránya 2011-re 11,6 százalékra csökkent, míg az evangélikusok 2001-es 3 százalékos aránya 2011-re 2,2 százalékra zsugorodott. A vallástalanok aránya a 2001-ben mért 14,5 százalékról 2011-re 18,2 százalékra emelkedett, a rejtőzködők aránya azonban a 2011-ben mért 10,8 százalékról 27,2 százalékra duzzadt (Harrach 2013).

A vallásosság fóbb indikátorai, így a templomba járás mértéke és az imádkozás gyakorisága is csökkennek vagy stagnálnak. Jelenleg a hetente legalább egyszer templomba járók aránya 9 százalék körül van hazánkban (Tomka - Zulehner 2008). Ezért önálló, jelentős társadalmi tőke dimenzióként értelmezni a vallást Magyarországon jelen pillanatban - az intézményes vallásosság szempontjából nem indokolt. A dimenzió részletes bemutatása azonban - főként globális jelentősége, sok esetben elsődlegessége miatt - igen. Ezért ezt esettanulmány formájában kutatásomhoz csatoltam.

A kortárs társadalomtudomány által alkalmazott társadalmi tőke elméletnek komoly dimenziója a vallási élet szférája. A társadalmi tőke elmélet főbb teoretikusai szinte kivétel nélkül hangsúlyozták a vallási hovatartozás, vallásosság és vallásgyakorlás fontosságát a társadalmi tőke megteremtődésében. Egyúttal egyféle módszertani újításként felvetem a vallási társadalmi tőke, mint tipologizálási faktor használatát a hagyományos vallási közösség tipológiákkal szemben illetve azok mellet. A hagyományos tipológiák absztrakt vallási-ideológiai faktorokat is tartalmaztak, és nem tértek ki az adott közösségek társadalmi szerepvállalására. 
Érvelésem szerint a vallási társadalmi tőke arra lenne kiválóan használható, hogy mérésre operacionalizált formában egyfajta új indikátora lehetne a különböző vallási közösségek társadalmi realitásainak, és egyfajta új tipologizáló tényezőként lehet felhasználható.

A vallási társadalmi tôkével kapcsolatban azt mutatom be, hogy föként az Egyesült Államokban milyen elméleti megfontolások és kutatási eredmények születtek a témában, milyen volt az elmélet fogadtatása, illetve az elmélet esetleges magyar szempontú relevanciáját is illusztrálni szándékozom. Az amerikai példákból általánosítható elméleti és empirikus tapasztalatok, valamint a magyar elméleti és kutatási eredmények összevetése további kutatási irányok kijelölését teszi lehetővé.

\subsection{VALLÁSI KÖZÖSSÉGEK KONFLIKTUSAI A PLURALIZMUS KORÁIG}

A vallási pluralizmus és sokféleség a modern korban a vallások békés együttélését jelenti. Nem csak azt a sokféleséget jelenti azonban a pluralizmus, ami napjainkban megtapasztalhatunk a vallási közösségek elterjedtsége szempontjából, hanem azt is jelenti, hogy ezek a közösségek békésen egymás mellett, egy társadalomban léteznek (Hutchison 2003). Nem volt ez mindig így. A vallásszabadság kivívása, a vallási pluralizmus megteremtődésének lehetősége a modern kor első vívmányai közé helyezhetők. Hiszen emlékezzünk vissza: a kelet és a nyugati keresztény egyház véleménykülönbségei komoly konfliktusokhoz vezettek el. A „Filioque” vita, ami a legfontosabb eltérés a kelet és a nyugati kereszténység elgondolásában előidézte az egyházszakadást, amely Kr. u. 1054-ben történt meg. A nagy egyházszakadás csak az egyik azon emblematikus események közül, amelyek esetében az egyik vallási közösség a másik vallási közösséget valamilyen szempontból deviánsnak, valamilyen szempontból eltérőnek bélyegezte. Itt ugye nem eltérő vallási közösségekről, csupán eltérő felekezetekről és teológiai nézetekről volt szó.

A következő időszak a XVI. századra tehető, amikor a kereszténységen belül ismét nagy változások zajlottak le. A reformáció keretében Luther Márton meghirdette azt, hogy a Római Katolikus Egyház deviáns, eltért a krisztusi tanítástól, túlzottan az anyagi javakra koncentrál. Szerinte az emberek nem értették az egyház üzenetét, és sok egyéb igen kemény üzenettel bélyegezte Luther deviánsnak 
a nyugati egyház papságát és a nyugati egyház tanítását. A reformáció ezektől az elgondolásoktól megtisztulva kívánt müködni, és ezektől az elgondolásoktól elszakadva, nemzeti nyelven próbált kommunikálni a hívekkel. Ez sok konfliktushoz vezetett el, igen véres összecsapások bontakoztak ki. Az ellenreformáció mozgalmában a Római Katolikus Egyház próbált választ adni a reformáció kihívására, és megakadályozni azt, hogy a reform gondolatok széles körben elterjedjenek. Próbálták a már elterjedt eszméket visszaszorítani és az írmagját is elfojtani ennek a vallási nézetkülönbségnek. A felekezetek küzdelmük során nem voltak restek egymást deviánsnak bélyegezni, és a vallási tanítás szempontjából kiemelkedő kérdésekben a racionális vagy tudományos alapon általában eldönthetetlen konfliktust fegyveres módon kezelni.

A XVII. századtól a kivándorlás is nagymértékü volt Európából, például a reformáció egyes csoportjai egy az egyben átköltöztek az a mai Amerikai Egyesült Államok területére, ahol vallási elgondolásaikat szabadon gyakorolhatták. Érdekes válaszok születtek a többi világvallás esetében is a vallási különbségek kérdésére. Ha nem kizárólag a keresztény felekezeteket nézzük, akkor láthatjuk, hogy például a zsidóság, a zsidó vallás követői sokszor áldozataivá váltak a vallási különbségnek és eltérésüknek a Kereszténységtől, ám a vallási tolerancia, a vallási türelem később rájuk is kiterjedt. A felvilágosodás korszakában Gotthold Ephraim Lessing felvilágosodás kori filozófus „A Bölcs Nátán” című drámájában olyan gondolatokat fogalmazott meg, melyek szerint a különböző világvallások egyaránt a letéteményesei lehetnek a legfőbb jónak, egyaránt az Isten által kiválasztott helyes vallások lehetnek és a kötelességük, hogy az ítélet pillanatáig ezért folyamatosan küzdjenek és folyamatosan dolgozzanak. Tehát egy aktív tevékenységet fejtsenek ki a jóra törekedve, ne pedig egymás különbözőségeivel foglalkozzanak.

Az európai vallásszabadság korszaka a Francia Forradalom után vált akadálymentesen lehetségessé, mely aztán föként a Kelet-Európai országokban 1947 után ismét megbicsaklott, hiszen a Szovjet típusú kommunista rendszer nem tette lehetővé a vallás szabad gyakorlását országainkban.

A kortárs közép-európai vallásszabadság alapja például az 1990. évi IV.-es törvény a lelkiismereti és vallásszabadságról Magyarországon, és hasonló törvények formájában került kodifikálásra a régió többi országában. A teljes vallásszabadság ismét előidézte azt, hogy vallási pluralizmus gyakorlatilag irányíthatatlanul tört rá ezekre az országokra, azaz nagyon-nagyon sok olyan vallási 
közösség jelent meg azon a vallási palettán, ahol korábban gyakorlatilag elfojtva müködhetett néhány vallási közösség.

\subsection{VALLÁSI KÖZÖSSÉGEK TUDOMÁNYOS TIPOLOGIZÁLÁSA}

Ez az új vallási pluralizmus nagyon nagy társadalmi sokkokhoz, morális pánikokhoz, és a vallási deviancia elgondolás széles körü elterjedéséhez vezetett. Ezen hatások vizsgálata szempontjából tárjuk fel, hogy a szociológia tudomány hogyan kategorizálja a vallási közösségeket, milyen kategóriában gondolkodik a vallási közösségek tipologizálásával kapcsolatban. Az egyik legismertebb tipológia egy kétdimenziós tipológiai tábla (21. Tábla), melynek egyik dimenziója a vallási közösség viszonya a társadalomhoz. Lényegében ez azt tartalmazza, hogy a vallási közösség tagjai mennyire pozitívnak, vagy negatívnak látják a társadalmi szerepüket, a társadalom általi való megítélésüket, és hogy ők maguk hogyan viszonyulnak ennek a társadalomnak az értékeihez.

21. Tábla - Kategorizálás a csoport és a társadalom viszonya, valamint a csoport saját legitimációs képe alapján

\begin{tabular}{|l|l|l|}
\hline \multirow{2}{*}{ Legitimációs kép } & \multicolumn{2}{|l|}{ Viszony a társadalomhoz } \\
\cline { 2 - 3 } & Pozitív & Negatív \\
\hline Exkluzív & egyház & szekta \\
\hline Pluralista & denomináció & kultusz \\
\hline
\end{tabular}

Forrás: (McGuire 2001, Török 2004)

A vallási közösségek viszonya a társadalomhoz egy igen sokdimenziós elgondolás, amelyet igen sok szociológiai változóval lehet mérni, s ebben az elméleti absztrakciós táblában gyakorlatilag két kategóriára szúkítettük le a közösségek viszonyát a társadalomhoz, mely lehet pozitív illetve negatív. A másik dimenzió, melynek mentén a vallási közösségek kategorizálását elvégezzük az a vallási közösségeknek a legitimációs képe. Legitimációs kép alatt a közösségeknek a megváltáshoz, 
a legfőbb szabaduláshoz, az üdvözüléshez kapcsolatos értékeit vizsgáljuk meg. Vannak közösségek, melyek kijelentik, hogy kizárólag a közösségen belül nyerhető el az üdvözülés, a legfőbb vallási jav. Ezeket a közösségeket „exkluzív” legitimációs képű közösségeknek nevezzük. Más közösségek azonban azt mondják, hogy a közösségen belüli tevékenykedés, a közösségen belüli tagság csak az egyik út az üdvösséghez, a végső vallási érték eléréséhez, és más utak is vezethetnek ugyanehhez a dologhoz. Ezeket a közösségeket „pluralista” legitimációs képü közösségeknek nevezzük. Hogyha a tipológiai tábla elemeit megnézzük, akkor láthatjuk, hogy a legitimációs kép szempontjából „exkluzív” és a társadalomhoz való viszony szempontjából „pozitív” közösségek kerülnek az „egyház” kategóriába. A római katolikus egyház esetében például egyértelmü a tanítás: „Extra Ecclesiam nulla salus", azaz egyházon kívül nincs megváltás ${ }^{24}$.

A szintén exkluzív legitimációs képú, ám a társadalomhoz negatívan viszonyuló közösségek a szekták, melyek szintén nem tartják elképzelhetőnek a rajtuk kívül álló megváltást, azonban tagjaik általában a társadalomhoz negatívan viszonyulnak. Az ilyen közösségek a társadalom tagjaihoz általában negatívan viszonyulnak. A szekta szociológiai értelemben egy mérési kritériumrendszer alapján meghatározott kategória, nem pedig a tanítása alapján megbélyegzett közösség. A szekta kategóriába tartozik a például a Magyarországi Jehova Tanúi Egyház, mint vallási közösség.

A legitimációs kép szempontjából pluralista és a társadalomhoz való viszonya alapján pozitív kategóriába eső közösségek a denominációk. A denomináció egy nagyon érdekes tipológiai elem. Ebbe a körbe beletartozik például a Magyarországi Baptista Egyház 2006-os felmérésünk eredményei alapján. Ennek a közösségnek a tagjai úgy vélik, hogy baptistának lenni csupán az egyik út az üdvözüléshez, s a többi keresztény felekezetben illetve más vallásokban és módokon is el lehet jutni az üdvösséghez. Viszonyuk a társadalomhoz alapvetően pozitív, és a társadalom is pozitívan viszonyul ennek a közösségnek a tagjaihoz.

Végül azok a közösségek, amelyeknek a legitimációs képe pluralista és a társadalomhoz való viszonyuk viszont negatív kultusznak tekinthetők. Ezek a kultuszok általában nem feltétlen intézményesült formában müködnek. Magyarországon is létezik néhány csoport, amely ebbe a kategóriába sorolható be.

24 Nem ilyen egyértelmű azonban a katolikus hívek véleménye a megváltás elérhetőségével kapcsolatban egyházon kívül és más közösségek keretein belül. 
A legitimációs kép mint tipologizáló tényező véleményem szerint nem tudja megfelelően ellátni feladatát, mivel annak mérésre operacionalizálása minden közösség esetében érvényesen szinte lehetetlen. A koncepciót továbbá igen absztraktnak és vallási-ideológiai szempontból túlzottan értékterheltnek gondolom. Ezt egy meglévő kutatási adatbázissal illusztrálom.

\subsection{SZOCIOLÓGIAI VIZSGÁLAT A TIPOLOGIZÁLÁS ALAPJÁUL}

A szociológiai szempontból denominációnak, illetve szektának tekinthető kategóriáknál megemlítettem két példát, a Magyarországi Baptista Egyházat és a Magyarországi Jehova Tanúi Egyházat. Ezeket a besorolásokat a tagok körében végzett kérdöíves felmérés eredményei alapján végeztük el. A tanúkkal 2003-ban készítettünk kérdőíves felmérést, a baptistákkal 2006-ban, a MABAVIT világtalálkozón ${ }^{25}$. Mind a két esetben kellően nagy az elemszám, a baptistáknál közel 300 fős mintánk volt. A tanúk esetében 467 kérdőívünk eredményei alapján készítettük el statisztikai elemzésünket. A tipológiai rendszer alátámasztására három kérdést fogunk megvizsgálni, az egyik kérdés így hangzik: Érzése szerint Ön hazájában saját gyülekezetével milyen kapcsolatban van? (22. Tábla)

22. Tábla - Érzése szerint Ön a hazájában saját gyülekezetével...

\begin{tabular}{|l|c|c|c|c|}
\cline { 2 - 5 } \multicolumn{1}{c|}{} & \multicolumn{2}{|c|}{ Baptista } & \multicolumn{2}{c|}{ Tanú } \\
\cline { 2 - 6 } \multicolumn{1}{c|}{} & $\mathbf{N}$ & $\mathbf{\%}$ & $\mathbf{N}$ & $\%$ \\
\hline Nagyon szoros kapcsolatban van & $\mathbf{1 5 0}$ & $\mathbf{5 0 , 8}$ & 433 & 92,7 \\
\hline Szoros kapcsolatban van & $\mathbf{1 1 7}$ & $\mathbf{3 9 , 7}$ & 31 & 6,6 \\
\hline Laza kapcsolatban van & $\mathbf{2 8}$ & $\mathbf{9 , 5}$ & 3 & 0,6 \\
\hline Összesen & $\mathbf{2 9 5}$ & $\mathbf{1 0 0 , 0}$ & 467 & 100,0 \\
\hline
\end{tabular}

25 Mindkét felmérést a Szegedi Tudományegyetem BTK Vallástudományi Tanszék munkatársai készítették. Kutatásvezető: Dr. Máté-Tóth András. 
A baptisták esetében a három válaszlehetőség közül a nagyon szoros kapcsolatban van válaszlehetôséget választotta 50.8 százalék. A szoros kapcsolatban van választási lehetôséget választotta 39.7 százalék, a laza kapcsolatban van választási lehetőséget választotta 9.5 százalék. A tanúk esetében a nagyon szoros kapcsolatban van válaszlehetőséget választotta 92.7 százalék, a szoros kapcsolatban van válaszlehetőséget választotta 6.6 százalék, laza kapcsolatban csupán 0.6 százalék érzi magát közösségével. Ez az elemzés megmutatja a két közösség teljesen eltérő jellegét. A baptisták között nincs meg az a kirívóan nagy fegyelem, amit a tanúk mutatnak a közösségükkel való kapcsolatuk irányában. A baptistáknál is fontos a közösségisség, ámde nem egyetlen és kizárólagos mérce. Talán azt lehet mondani, hogy a baptista viszonyulás egy olyan társadalmi viszonyulás, amely teret hagy a közösség egyes elképzeléseivel, cselekedeteivel kapcsolatos kritikáknak. A tanúk esetében sokkal inkább a kritikátlanság veszélye vetődik fel, hiszen a nagyfokú heteronómia megléte azt mutatja a külső szemlélő számára, hogy a közösség vezetése nagyon-nagyon megköti a tagságot a csoport belső szerkezetéhez.

Hogyha megvizsgáljuk azt, hogy a magyar társadalom a hívek véleménye szerint hogyan viszonyul az ő vallási közösségükhöz, a baptisták esetében igen érdekes képet fogunk kapni. Hogyha a legnagyobb relatív többségü kategóriát keressük, akkor az „általában barátian” kategóriát választotta legtöbb hívő, 36 százalék mondta, hogy a magyar társadalom általában barátian viszonyul a baptista közösséghez. (23. Tábla)

\section{Tábla - A magyar társadalom hogyan viszonyul az Ön közösségéhez?}

\begin{tabular}{|l|l|l|l|l|}
\cline { 2 - 5 } \multicolumn{1}{c|}{} & \multicolumn{2}{c|}{ Baptista } & \multicolumn{2}{c|}{ Tanú } \\
\cline { 2 - 6 } \multicolumn{1}{c|}{} & \multicolumn{1}{c|}{ N } & \multicolumn{1}{c|}{$\%$} & N & \% \\
\hline Általában ellenségesen & 5 & 1,7 & 62 & 13,5 \\
\hline Néha ellenségesen & 50 & 17,5 & 191 & 41,5 \\
\hline Közömbösen & 74 & 25,9 & 86 & 18,7 \\
\hline Néha barátságosan & 54 & 18,9 & 59 & 12,8 \\
\hline Általában barátságosan & 103 & 36,0 & 62 & 13,5 \\
\hline Összesen & $\mathbf{2 8 6}$ & $\mathbf{1 0 0 , 0}$ & 460 & 100,0 \\
\hline
\end{tabular}


Azt, hogy a közösséghez általában ellenségesen viszonyul a magyar társadalom csupán 1,7 százalék fejezte ki, azt, hogy néha ellenségesen 17,5 százalék mondta. Azt, hogy közömbösen 25,9 százalék állította, és az, hogy néha barátian 18,9 százalék véleménye volt. Hogyha egy összegzést akarunk vonni, akkor láthatjuk, hogy 55 százalék azt mondja, hogy legalább néha barátian viszonyul a magyar társadalom az egyházához, és $25 \%$ szerint a társadalom általában közömbös a baptista közösséghez. Ez egy viszonylag pozitív kép a közösség részéről a társadalommal kapcsolatban.

A tanúk esetében a relatív többségbe a „néha ellenségesen” kategória került, amelyet 41,5 százalék választott. Az ,általában ellenségesen” kategóriát 13.5 százalék választotta, tehát a tanúk esetében összesen 55 százalék szerint a magyar társadalom valamilyen mértékben ellenséges a közösségükkel. 18,7 százalék szerint közömbös, és összesen körülbelül 25\% százalék szerint viszonyul legalább néha barátian a magyar társadalom a Jehova Tanúi közösséghez. Ennek alapján látható, hogy a baptisták nyitottabbak, barátságosabbnak tételezik a társadalmat a közösségük iránt. A tanúk zártabbak, sokkal negatívabbnak tételezik a társadalmat az ő közösségük iránt.

A tipológia másik fontos változója a megváltás, üdvözülés kérdése. Egyházon belüli vagy egyházon kívüli elérhetősége szempontjából igen eltérően nyilatkoztak a baptisták és a tanúk. (24. Tábla) A baptisták képe a denominációs irányába mutat, hiszen csupán 8,9 százalék mondta azt, hogy a megváltás kizárólag saját egyházukban érhető el. Ellenben ezzel szemben 46,8 százalék azt állította, hogy a megváltás elérhető bármely egyházban, s emellett további kontrasztként 43,9 százalék azt mondta, hogy a megváltás egyházakon kívül is elérhető az emberek számára.

24. Tábla - Az Ön véleménye szerint a megváltás elérhető...

\begin{tabular}{|l|c|c|c|c|}
\cline { 2 - 5 } \multicolumn{1}{c|}{} & \multicolumn{2}{c|}{ Baptista } & \multicolumn{2}{c|}{ Tanú } \\
\cline { 2 - 5 } \multicolumn{1}{c|}{} & $\mathbf{N}$ & $\mathbf{\%}$ & $\mathbf{N}$ & $\mathbf{\%}$ \\
\hline Csak a saját egyházban & $\mathbf{2 5}$ & $\mathbf{8 , 9}$ & 391 & 87,3 \\
\hline Bármely egyházban & $\mathbf{1 3 1}$ & $\mathbf{4 6 , 8}$ & 0 & - \\
\hline Az egyházakon kívül is & $\mathbf{1 2 3}$ & $\mathbf{4 3 , 9}$ & 19 & 4,2 \\
\hline A megváltás nem létezik & $\mathbf{1}$ & $\mathbf{, 4}$ & 38 & 8,5 \\
\hline Összesen & $\mathbf{2 8 0}$ & $\mathbf{1 0 0 , 0}$ & $\mathbf{4 4 8}$ & $\mathbf{1 0 0 , 0}$ \\
\hline
\end{tabular}


A megváltásképnek egy igen pluralista változatát találtuk a baptista hívők körében. A Jehova Tanúi esetében azoknak az aránya, akik azt mondják, hogy a megváltás csak a saját egyházukban érhető el 87,3 százalék. Ez igen jelentős többségnek tekinthető. A tanúk konzervatívan csak saját szervezetük keretein belül látják elérhetőnek a legfőbb vallási javat. 4,2 százalékuk azt mondta, hogy a megváltás elérhető az egyházakon kívül, és 8,5 százalék azt mondta, hogy a megváltás egyáltalán nem létezik. A megváltás létezését tagadó elgondolás a Jehova Tanúi speciális teológiájához kapcsolódó elgondolás, melynek megjelenése a válaszok között alátámasztotta, hogy mintavételünk megfelelően képezte le a közösség teljes vélemény spektrumát. Egyetlen tanú sem állította, hogy az ő közösségükön kívül, más egyházban is elérhető a megváltás. Ha összevetjük a baptisták és a tanúk adatait, láthatjuk, hogy a baptisták nyitottak. Ök a megváltás többféle módját ismerik és elismerik, és pluralista képük van az üdvözüléssel és megváltással kapcsolatban. A tanúknak ellenben egy egydimenziós megváltás él a fejében, amely azt mutatja, hogy vagy saját egyházukon belül nyerhető el az üdvösség, vagy pedig egyáltalán nem is létezik. Csupán néhányan tartják elképzelhetőnek, hogy egyházon kívül is lehet üdvözülni, de más egyházakban ezt senki sem látja lehetségesnek. A tipológia szempontjából tehát a baptisták egyértelmủen a pluralista megváltásképet, a tanúk pedig az exkluzívista megváltásképet képviselik. Ezzel a tipologizálási módszerrel egy nagyon egyszerü, szociológiai kategóriáknak megfelelő besorolását tudtuk elvégezni a közösségeknek, tagságuk véleménye alapján. Azonban ez a besorolás megmarad az absztrakciók szintjén, amelyekből maga az elméleti modell felépül.

\section{4 ÚJ UTAK A VALLÁSI KÖZÖSSÉGEK TIPOLOGIZÁLÁSÁBAN}

A fentebb bemutatott, kétdimenziós és négyelemü vallási közösség tipológiánál azonban természetesen lényegesen bonyolultabb, több dimenziós egy vallási közösség hozzá járulása a társadalomban, egy vallási közösség múködése a társadalmunkban. Éppen ezért én ebben a kutatásban egy alternatív tipologizálási rendszerre teszek javaslatot, egy alternatív tipologizálási rendszer bemutatására teszek kísérletet. Alapvetően azt javaslom, hogy a vallási közösségeket társadalmi hozzájárulásaik és a társadalomban végzett tevékenységeik alapján kell tipologizálni. Ez az elgondolkodás nagyban összecseng Andrew Greely (1997) elgondolásával, aki szerint az önkéntesség terjesztése az egyik legfontosabb szerepe a vallási 
közösségeknek a társadalomban. Az Egyesült Államokban mindenfajta önkéntességi kétharmada vallási alapon szerveződik, és ez a világi önkéntességre is igaz. Nagyon fontos szerepe lehet a vallási közösségeknek az elesettek, a hajléktalanok és a szenvedélybetegek segítésében, amennyiben ezt nem kötik közvetlen vallási belépéshez, megtéréshez. Mindenképpen a társadalom számára pozitív a szociális feladatok megoldásában való szerepvállalás. A közösségek általában társadalmi szerepet is vállalnak, azaz kiállnak a számukra fontos célokért, nézetekért és elgondolásokért. Ez a társadalmi szerepvállalás kifejezetten fontos azért, hogy az értékek, amelyeket ezek a közösségek képviselnek, széles körben megismerhetően legyenek. Az esetleges értékvesztettség állapotában ezek az értékek iránymutatóként szolgálhatnak a társadalom tagjai számára, példaként tudnak szolgálni széles rétegek számára is. A közösségek tagjaik számára tudást és tapasztalatokat biztosítanak, a közösségeken belül szocializációs funkciót látnak el. A tagok konkrétan vallási tudást szereznek, és vallási információkra tesznek szert, a közösségen belül szocializálódnak, a közösségi részvétel normáit sajátítják el. Megtanulják a nyilvános szereplés, a nyilvános beszéd és a közéleti részvétel legalapvetőbb módozatait. A vallási közösségben elnyert szocializáció által ezek a hívek a társadalomban is sikeresen tudnak együtt élni, sikeresen tudnak integrálódni. Sok közösség állami és önkormányzati funkciókat, feladatokat vállal át, például idősek otthonát müködtet, oktatási intézményt és szociális szolgáltatást müködtet, kórházakban szolgáltatásokat nyújt. Ezeknek a funkcióknak az ellátása a társadalom szempontjából egy kétségtelenül hasznos dolog, és a legfontosabb alternatív tipologizálási változó pedig az, hogy a közösségben létrejövő kapcsolatok milyen jellegủ kapcsolatok. Megkötő vagy pedig összekötő jellegủek. A gyakorlatban ez azt jelenti, hogy a közösségben felszedett kapcsolati tőke és kapcsolathálózati rendszer kizárólag a közösségen belül hasznos-e, vagy képes a közösségen kívül is hálózati elönyökhöz juttatni az azt birtokló közösségi tagot.

Hogyha a vallási közösségek alternatív tipologizálásával összevetjük a vallási deviancia elgondolását, akkor a legfontosabb kijelentés az, hogy a vallási deviancia a mai társadalomban eltérő formákban jeleik meg. Sok esetben a vallás közösségek értékhordozók, és a társadalom értékvesztett. Vannak azonban olyan vallási közösségek, amelyek a társadalmi értékektől való jelentős eltéréseik alapján deviánsnak tekinthetőek. Éppen ezért ez a viszonyrendszer igen bonyolult, és szociológiai vizsgálódást igényel ahhoz, hogy pontosan meghatározható legyen. Ahhoz, hogy megállapítsuk, hogy egy vallási közösség értékhordozó-e vagy pedig deviáns, alapos kutatás és adatfeldolgozás szükséges, az előbbiekben ismertetett 
dimenziórendszerek mentén. Egy fontos elméleti koncepció az, ami segítséget nyújthat nekünk a társadalmi együttmüködés illetve deviancia szintjének megállapításában. Ez az elméleti koncepció a vallási társadalmi tóke elméleti koncepciója. A vallási társadalmi tőke elmélet kimondja, hogy a közösségekben termelődő társadalmi tőke eltérő típusú és volumenű lehet. Kijelenti továbbá, hogy a közösség nem független társadalmi környezetétől. A vallási társadalmi tőke a személyek és a hálózatok szintjén is értelmezhető dolog. Hogyha meg kívánjuk vizsgálni a vallási társadalmi tőke dimenzióit, akkor például olyan részekre tudunk kitérni, mint a vallás hatása a politikai részvételre, a közösség erkölcsi utasításainak hatása az egyének viselkedésére és a társadalmi normarendszerre. Ilyen dimenzió a vallás hatása a bizalom szintjére, azaz, hogy az emberek mennyire rendelkeznek általánosított bizalommal a társadalomban és mennyire bíznak a társadalmi intézményekben.

A vallási társadalmi tőke szintje és jellege befolyásolja a közösségek és a személyek szolidaritás és karitász részvételét. A vallási társadalmi tőke mértéke meghatározza a vallásosság gerjesztette önkéntesség és részvétel mértékét, és meghatározza, hogy a gyülekezeti tagság hálózatai mennyire nyitottak vagy zártak, mennyire megkötő vagy összekötő társadalmi tőkét termelnek. Amennyiben a teljes vallási tőke társadalmi dimenziót tekintjük, akkor azt mondhatjuk, hogy ez egy igen fontos meghatározója a társadalmi integráció általában vett jelenségének. Ha összevetjük azt, hogy a vallási társadalmi tőke és a vallási közösségi részvétel hogyan viszonyul egymáshoz, akkor azt mondhatjuk, hogy a két jelenség erös öszszefüggésben áll egymással. Eva Cox (1998) és Robert D. Putnam (2000) kutatók a polgári erényeket tekintik a társadalmi tőke alapjának, és azt mondják, hogy a társadalmi tőkét fenyegető veszélyek a közjót is fenyegetik. A vallási közösségek társadalmi részvétele is a társadalmi integráció erősítéséhez vagy gyengítéséhez tud hozzájárulni. Éppen ezért a vallási társadalmi tőke különböző dimenzióinak vizsgálata segítséget nyújthat nekünk abban, hogy megállapíthassuk, az egyes közösségek együttmúködőek vagy pedig elzárkózóak a társadalmi életben. A legtöbb vallási közösség együttmüködö, és a legtöbb vallási közösség célja az, hogy együttmüködjön a társadalomban. Ezen közösségek azonban különböző motivációkkal és különböző háttérrel, különböző vallási elgondolásokkal viszonyulnak a társadalom felé. Ezen elgondolások vizsgálata nem a szociológusok dolga, hiszen ezek általában vallási beállítottságok. A szociológusok és a társadalomkutatók, valamint valláskutatók hivatottak azonban megvizsgálni az adott vallási közösség társadalmi részvételének formáit és módját, a közösség társadalmi szerepét és 
vállalt faladatait, a tagság véleményét és ennek alapján egy kifinomultabb tipológiai rendszerben értelmezni, hogy az adott közösség együtt müködő e vagy pedig bezárkózó a magyar társadalom életében. Ennek érdekében célszerú alaposabban feltárnunk és körbejárnunk a vallási társadalmi tôke elméleti alapjait.

\subsection{JAMES S. COLEMAN A VALLÁS ÉS TÁRSADALMI TŐKE VISZONYÁRÓL}

James S. Coleman „A társadalmi töke az emberi töke termelésében” címü, 1988ban megjelent korszakos jelentőségü cikkében több bemutatott példájában kiemelte a vallási hovatartozás és elkötelezettség szerepét és pozitív hatásait a társadalmi tőke megteremtődésére. Az egyik példában a New York-i gyémántpiac müködésén keresztül mutatta be, hogyan befolyásolják a családi, etnikai és vallási szálak a kereskedelmet. Az említett gyémántpiacon sok ezer, néha sok százezer dollár értékü kövek cserélnek gazdát a kereskedők között, akik otthonuk nyugalmában tanulmányozhatják az átvett árut, mielőtt döntenének a vásárlásról. Ekkora érték esetében már felmerülhet, hogy egy kő kicserélésével is vagyonokra lehet szert tenni. Ezt azonban meggátolja, hogy a gyémántpiac szereplői egy helyen élnek Brooklynban, azonos vallásúak, gyakori közöttük a belterjes házasság, és nem ritkán ugyanabba a zsinagógába járnak vallásgyakorlás céljából. A bizalmat, a bizalomra méltóság intézményét az a fenyegetettség tartja fenn ebben az esetben, hogy az esetleges normasértő egyaránt elvesztené közösségi, családi és vallási kapcsolatait. Ebben a formában a társadalmi tőke - melynek egy része vallási alapon keletkezik - elősegíti, hogy a piac sikeresen és hatékonyan müködjön (Coleman 1988, 98-99o.).

Egy másik példájában Coleman a tanulók iskolai teljesítményét vizsgálja meg a családi háttér és több más tényező mellett a felekezeti hovatartozás és vallásgyakorlás adatai alapján. Vizsgálatában a rosszabb iskolai teljesítmény mérőszáma a nagyobb mértékủ lemorzsolódás volt. Elmondható, hogy eredményei alapján a katolikus iskolák lényegesen alacsonyabb lemorzsolódási aránnyal rendelkeztek, mint az állami iskolák vagy más magániskolák. Ennek oka Coleman megállapítása szerint az, hogy a vallásos fiatalok a vallásgyakorlásukon keresztül többgenerációs társadalmi kapcsolathálózat megbecsült tagjaivá válnak, és ezáltal magasabb társadalmi tőkével rendelkeznek, mint nem vallásos társaik. Az iskolák nem katolikus jellegük által biztosították a tanulók alacsonyabb lemorzsolódását, mivel az alacsonyabb adat csupán a vallásukat rendszeresen 
gyakorló tanulók esetében volt igaz. A vizsgálatot végrehajtotta a szerző nyolc nem katolikus iskola mintáján is, melyből három baptista, kettő zsidó és három más felekezeti fenntartású volt. A vallási tényező fontosságát a társadalmi tőke megteremtődésében igazolta az, hogy ezeknek az iskoláknak a lemorzsolódási arányszámai hasonlóan alacsonyak voltak, mint a katolikus iskolák vonatkozó számai (Coleman 1988, 114-115 o.).

Coleman eredményei alapján tehát egyértelmüen megállapítható, hogy a vallási szervezeti tagság azon típusa, mely rendszeres részvételen keresztül valósul meg, egyféle védőhálóként müködik a társadalmi élet több területén. További elemzéseket igénylő, tudományos kérdés azonban, hogy ezt a hálót pusztán a vallási részvétel szövi erőssé, avagy inkább kompakt, világos normarendszerrel rendelkező kapcsolathálózati tagság eredménye.

\subsection{ROBERT D. PUTNAM A VALLÁSRÓL ÉS TÁRSADALMI TŐKÉRŐL}

Robert D. Putnam, a társadalmi tőke elmélet egyik fö teoretikusa is kiemelt szerepet tulajdonít a vallási közösségeknek a társadalmi tőketermelésben. „Bowling Alone" címü könyvében teljes fejezetet szentel a vallási részvételnek és az ebből adódóan létrejövő „speciális” társadalmi tőkének. A könyvet alapvetően a társadalmi tőke „közjó” típusú felfogása jellemzi. Mondanivalója az, hogy Amerikában válságban van a közösségi részvétel és a demokrácia intézménye. A szerző állításait a társadalmi tőke különböző dimenzióinak vizsgálatával bizonyítja. A vallási dimenzión kívül szinte minden más dimenzióban rohamosan terjedő válságról és visszaesésről számol be (Putnam 2000, 65-79 o.).

A vallási dimenzióról írt fejezetből megtudhatjuk, hogy Putnam szerint az Egyesült Államokban a hiten alapuló közösségek, melyeknek tagjai együtt járnak vallásgyakorlás céljából gyülekezeti alkalmakra, a legfontosabb társadalmi tőkét őrző intézmények részei. Leírja, hogy ha durván értelmezzük a számokat, az önkéntes szervezeti részvétel fele, az adakozások fele és az önkéntes munkavégzés fele vallási meggyőződésen alapul. Ezért elmondható, hogy a személyek vallási elköteleződése fontos meghatározója Amerika társadalmi tőkéjének. Ennek egyik lehetséges oka, hogy a vallási közösségek az Egyesült Államokban sokszor támogatnak olyan társadalmi célú, közhasznú tevékenységeket, amelyek nincsenek kapcsolatban a vallási élettel (Putnam 2000, 66 o.). 
Putnam megjegyzi még, hogy a vallási részvétel hozzájárul a közéleti képességek és normák elsajátításához, a közösségi érdekek és közéleti szerepre toborzás folyamatának megismeréséhez is. A vallási szempontból aktív férfiak és nők megtanulnak nyilvánosan beszélni, üléseket levezetni, nyilvános vitákban részt venni és adminisztratív felelősséget vállalni. Munkájuk során megismerkednek és összebarátkoznak másokkal, akik meghívják őket más szervezetekbe, csoportokba. Éppen a fentebb felsorolt tényezők miatt az aktív vallásgyakorlók nagyobb eséllyel fognak részt venni valláshoz nem kötődő szervezetek munkájában, a politikai folyamatokban, a választáson, és mélyebb informális társadalmi kapcsolatokkal fognak rendelkezni, mint nem aktív vallásgyakorló társaik (Putnam 2000, 66-67o.).

\subsection{ROBERT BELLAH ÉS A VALLÁS JELENTŐSÉGE AZ AMERIKAI ÉLETFORMÁBAN}

Robert Bellah írja Habits of the Heart (Bellah-Madsen-Sullivan-Swidler-Tipton, 1996) címú müvében, hogy az amerikaiak legtöbbször vallásuk révén vonódnak be a helyi közösségi életbe. A társadalmi tőke ezekben a közösségekben alakul ki és őrződik meg. A szerző előző állítását alátámasztandó megjegyzi, hogy az amerikaiak a vallási szervezetekben több pénzt adományoznak és több önkéntes munkát végeznek, mint a nem vallásos szervezetekben. Bellah ezt a magas, 40 százalék körüli hetenkénti templomba járási értékkel hozza összefüggésbe, amely kimagasló, összehasonlítva akár Nyugat Európával, akár Kanadával (Bellah-Madsen et al. 1996, 219 o.).

Bellah ír még az amerikai vallásosság más egyedi jegyeiről is, így az extrém individualizmusról, ami az amerikai emberek vallásfelfogásában tapasztalható meg. A keresztény és zsidó hagyomány szerint az egyház elsőbbséget élvez az egyénnel szemben, amelynek ugyan az ember tagja, de maga az intézmény tagjai születése elött is létezett, és a haláluk után is létezni fog. Az egyén viszonya Istennel teljesen személyes, de a kapcsolatot a közösségi élet mintái vezérlik. A közösség és a vallási tradíció ilyen típusú meghatározottsága Bellah szerint nehezen érthető az amerikai emberek számára. Nehéz számukra megemészteni azt, hogy azok nem egyéni választás kérdései. Felfogásuk sokkal közelebb áll ahhoz a kutatási eredményhez, mely kimondja, hogy 1978-ban az amerikaiak nyolcvan százaléka egyetértett azzal az állítással, hogy az egyéneknek saját maguknak kell kialakítani vallási meggyőződésüket, függetlenül az egyházaktól (Bellah, Madsen et al. 1996, 227-228o.). 
A fentiek tükrében tehát egyértelmű, hogy a közösségi részvétel visszaesését és a társadalmi tôke erodálódását Bellah is kiemelt veszélynek tartja a speciális amerikai életformára. Bizonyította, hogy az amerikai közösségiség legfontosabb motorja a vallás, illetve, hogy a vallás az amerikai létforma elidegeníthetetlen része. Szerinte azonban ezt az életformát veszély fenyegeti, amitől szinte bármi áron meg kell azt menteni (Bellah, Madsen et al. 1996, xvi-xxi o.).

\subsection{ANDREW GREELEY KRITIKÁJA - VISSZA A KOMPAKT HÁLÓZATOK ELMÉLETÉHEZ}

Andrew Greeley (1997) cikkében bírálta azon szerzők munkásságát, akik a társadalmi tőkét olyan indikátornak tekintették, amely megmutatja egy társadalom „egészségességét”. Kritikája kiterjed Robert D. Putnam és Robert Bellah munkáira is, akik szerinte kiforgatták James S. Coleman eredeti koncepcióját, és a koncepciót kizárólag saját népszerüségük növelése érdekében népszerüsítették, vészharangot kongatva az amerikai társadalom fölött. Greeley szerint a társadalmi tőke csökkenése nem feltétlen jelzi, hogy a társadalom „egészségtelen” változásokon megy keresztül, hiszen nem tudhatjuk, hogy mi is az egészséges állapot. Egyértelmű ál-nosztalgiaként jellemzi a fentebb említett két tudós írásait, amelyek a Tocqueville korszakára jellemző közösségi részvételi arányokat sírják vissza (Greeley 1997, 587 o.).

Kritikája alátámasztása érdekében Greeley az önkéntesség jelenségkörét vizsgálta meg az Egyesült Államokban. Eredményei szerint, melyet a World Value Studies 1981-es és 1990-es adatfelvételeire alapoz, az amerikaiak sokkal nagyobb eséllyel végeznek önkéntes munkát, mint bármely más ország lakói. Ehhez járul még az önkéntesek arányának nagymértékü növekedése 1981-ről 1990-re. A szerző az önkéntesség becslésére minden országban (kivéve Írországot) a legjobb magyarázó változónak a vallási szervezeti tagságot és a templomba járást találta (Greeley 1997, 590 o.).

Greeley a fent megnevezett adatbázisok alapján végez el egy összehasonlítást az NSZK és az USA esetében. Az amerikaiak negyvenhét százaléka dolgozik önkéntesként, míg a nyugat németeknek mindössze harminc százaléka. Ha figyelembe vesszük a két ország vallási szervezeti tagsági és templomba járási adatait, és az amerikai adatokat a nyugatnémet szintre transzformáljuk, azt tapasztalhatjuk, hogy az önkéntességben tapasztalható szignifikáns különbségek 
is eltünnek. Ez az eredmény persze nem feltétlen azt bizonyítja, hogy a vallási szerveződések, szervezetek társadalmi tőkét generálnak, csupán azt támasztja alá, hogy a templomba járás és a szervezetekhez tartozás strukturált kapcsolatokat hoz létre, amelyek hozzájárulnak az önkéntesség növekedéséhez. Greeley szerint egyáltalán nem lehet „visszaesésről” vagy recesszióról beszélni az amerikai társadalmi tőkében, amikor az adatok mást mutatnak (Greeley 1997, 590-591 o.).

\subsection{FÓKUSZBAN A VALLÁSI TÁRSADALMI TŐKE}

John A. Coleman kutatásai hasonló eredményekkel végződtek, mint Robert D. Putnam megállapításai. Eszerint az Egyesült Államokban a vallás intézménye több társadalmi tőkét generál, mint bármelyik másik amerikai intézmény. A vallási közösségek Amerikában Coleman véleménye szerint gyakran és egyértelmúen elősegítik a civil társadalmi részvételt. A vallási szervezetek információt biztosítanak tagjaiknak, hogy hogyan és miként szolgálhatnak a szervezeten belül és kívül egyaránt. Biztosítják az ehhez a szolgálathoz szükséges kapcsolatrendszert, találkozási helyet és szervezési képességet, összességében mindent, amire szükség van ahhoz, hogy a jó szándékból cselekvés lehessen (J. A. Coleman 2003).

A vallási motivációból fakadóan önkéntes tevékenységet végzők inkább hajlamosak saját önkéntes részvételüket közösségi okokkal, a közös jó felismerésével magyarázni, míg a nem vallási okból önkéntesek individuális nyelvezetben számolnak be motivációikról. Több, a témában végzett kutatás kimutatta, hogy az emberek sokkal inkább hajlandóak pénzükből vagy idejükből adni akár a vallással össze nem függő, szekuláris célok elérése érdekében is, ha vallási közösségi tagok. A választási részvétel esélyét is szignifikánsan növeli, ha valaki tag (John A. Coleman 2003).

John. A. Coleman felismerte, hogy a vallás szerepe a demokratikus értékrend kialakulásában nem merül ki a közösségi látásmód fejlesztésében. A korábban idézett szerzőkhöz hasonlóan Coleman is egyet ért azzal, hogy a vallási közösségekben a nyilvános szereplésekhez szükséges készségeket is elsajátíthatják azok, akik számára ez más körülmények között nem volna lehetséges. Cikkében megemlítette, hogy Verba, Schlozman és Brady nagyléptékü tanulmányban számolt be a politikai és civil önkéntesség helyzetéről az Egyesült Államokban, és arra a következtetésre jutottak, hogy a vallás nagymértékben hozzájárul az ország demokratikus 
potenciáljának fejlesztéséhez. A vallási közösségek lényegében abban jobbak a munkahelyek és a civil szféra intézményeinél, hogy olyanok számára is közszereplési képességeket tudnak tanítani, akik nem rendelkeznek az azokba bekerüléshez szükséges feltételekkel - a középosztálybeli származással és magas képzettséggel. Lényegében tehát, míg a nem vallási alapú szerveződések azoknak adnak, akik már amúgy is rendelkeznek valamivel, a vallási alapúak elérhetővé teszik a szükséges képességeket és készségeket a hátrányosabb helyzetben lévők számára, és így járulnak hozzá az esélyegyenlőség megteremtéséhez. Ezzel a szerepvállalással bizonyos mértékig ellensúlyozzák a közszerepléshez szükséges képességek és készségek piacán jelen lévő többi intézményt (John A. Coleman 2003).

A téma egy másik jelentős szerzője, Robert Wuthnow írja, hogy a vallás szerepe a közéleti részvételre történő mobilizálásban többféleképpen értelmezhető. Fentebb már idézett empirikus bizonyítékok alapján, amelyek a Gallup felmérésén alapulnak, Wuthnow is megjegyzi, hogy a rendszeres vallásgyakorlók sokkal nagyobb eséllyel áldoznak pénzükből vagy idejükből az önkéntes szervezetek támogatására, mint a nem rendszeres vallásgyakorló emberek. Ez az állítás még akkor is igaz, ha a támogatandó szervezet semmilyen kapcsolatban sincsen a gyülekezetükkel, egyházukkal (Hodkingson et al. (1995) idézi: Wuthnow 1999, 333 o.).

Egyúttal fontos azt is elmondani, hogy a politikai mobilizációval kapcsolatos amerikai kutatások alapján a gyülekezetek azok között a nagyon fontos helyek között kapnak helyet, ahol az emberek megtanulják az átadható, közéleti részvételhez szükséges képességeket (Verba-Schlozman-Brady (1995), idézi: Wuthnow 1999, 333 o.).

Wuthnow (1991) további kutatási eredményei alapján elmondható, hogy az aktív templomba járó emberek sokkal nagyobb eséllyel találkoznak olyan vallási tanításokkal, amelyek a szomszédok szeretetére és a felelős polgári életre biztatják őket. Sokkal valószínübb, hogy ezek az emberek rendelkezni fognak társadalmi tőkével a gyülekezetükön belüli kapcsolódásaikon keresztül. Ezt a fajta társadalmi tökét fel lehet használni a mobilizálásra, illetve birtokosai nagyobb eséllyel lesznek tisztában a közösségükben létező szükségekkel és lehetőségekkel, hiszen azokat a gyülekezeti kapcsolataikon keresztül megismerhették (Wuthnow 1999, 334 o.).

A nem vallási önkéntes szervezeti tagság tekintetében Wuthnow kutatásai alapján elmondható, hogy a rendszeres templomba járás felekezettől függetlenül nagyban meghatározó ebben a dimenzióban. Az 1974-es és 1991-es GSS kérdőív adatainak feldolgozása megmutatta, hogy az Egyesült Államokban a rendszeres templomba járók húsz százalékkal nagyobb eséllyel voltak tagjai nem vallási önkéntes szervezetnek, mint a ritkábban megjelenők (Wuthnow 1999, 341-343o.). 
Eric Uslaner szerint a vallási értékeknél is fontosabb meghatározója az önkéntességnek a másokkal való közös kapocs felismerése. A bizalom egymásban és kifejezetten az idegenekben, akik különböznek tölünk, megnöveli annak az esélyét, hogy időt szánjunk rájuk. Ez a fajta bizalom a másokban azon a morális alapálláson nyugszik, hogy mindannyian egy erkölcsi közösség tagjai vagyunk, elkötelezettségekkel egymás iránt. Ezek a mozgató indokok inkább származnak egy erkölcsi kódrendszerből, mint a reciprocitás iránti elvárásból. Az emberek, akik megbíznak egymásban, a világot jótékony helynek tartják, és elkötelezettséget éreznek, hogy jobbá tegyék azt. Vannak emberek, akiknek anyagi javakból kevesebb van, de ők ugyanannak az erkölcsi közösségnek a tagjai, mint akiknek több van. A bizakodók tehát erkölcsi kötelességnek érzik, hogy segítsék azokat az embereket, akiknek kevesebb jutott (Uslaner 2001, 106 o.).

A társadalmi összekapcsoltság is elősegíti a civil részvételt, de elmondható, hogy ez kevésbé központi mozgatórugó, mint az értékek, és erősen függ az egyének személyes értékrendjétől. A társadalmi kapcsolatok kötéseket hoznak létre az emberek között, feladatokat és jutalmakat adnak nekik közösségeikben. Házasnak lenni, háztulajdonosnak lenni és a közösség tagjának lenni szintén megerősítik a kötéseket a helyi közösség felé, és növelik a közéleti aktivizálódás esélyét (Uslaner 2001, 106 o.).

Egy közösség társadalmi élettere alapozza meg társadalmi tőkéjét. A szervezeti jegyek, normák, a kialakult hálózat és intézményesült bizalom teremtik meg a civil élet alapjait. Nancy Ammerman értelmezésében a társadalmi tőke részben bizalomból és kölcsönös felelősségérzetből áll - egyrészt a közösséggel kapcsolatos információk formájában, másrészt olyan normák formájában melyek elősegítik a közösségi viselkedést, és visszaszorítják az antiszociális viselkedést. Az emberek, a jelentéstartalmak és a viszonyok az a három dolog a közösségen belül, amelyek megteremtik a társadalmi tőkét. Ez a társadalmi termék megerősíti a közösséget, lehetővé teszi az „embernek maradást a farkasok között”, az értékadást, valamint megteremtik a társadalmi interakciók lehetőségét (Ammerman, idézi: EieslandWarner 1998, 73 o.).

Elmondható, hogy a társadalmi tőke nem mindig jelenik meg elégséges menynyiségben. Túl gyakran fordul elő, hogy szomszédok gyanakodnak egymásra, a gyülekezetekben sikkasztás történik, a politikusok a közjavakat herdálják. A nagyobb mennyiségü társadalmi tőke a kutatási eredmények szerint ellensúlyozhatja a fentebb felsorolt diszfunkciókat (Eiesland-Warner 1998, 74 o.). 


\subsection{TÁRSADALMI TŐKE ÉS VALLÁSKUTATÁS MAGYARORSZÁGON}

A vallás kérdése a magyar, társadalmi tőkéről szóló társadalomtudományi szakirodalomban igencsak marginálisnak tekinthető. Üdítő kivételként említhető meg, hogy Szántó Zoltán és Orbán Annamária általában a társadalmi tőkéről írt cikkükben kitérnek vallási vonatkozásokra. A szerzők utalnak arra, hogy léteznek olyan csoportok, például a vallási közösségek, melyek eleve magas szintủ társadalmi tőkével rendelkeznek (Orbán-Szántó 2005, 65 o.).

A társadalmi tőke növelésének lehetőségeivel kapcsolatban megjegyzik:

„A társadalmi töke növelésének eszköze, illetve forrása lehet a vallás, mely Európa kivételével az egész világon erösen tartja magát, sőt terjed, elsősorban a fejlödö latin-amerikai, afrikai és ázsiai országokban. A vallás azonban lehet káros hatással is egyes társadalmakra vagy akár az egész világra nézve, ha a különféle vallási szektákat és a terrorizmustól sem visszariadó fanatikusokat nézzük. Mindazonáltal a kultúra és a kulturális hagyományok átörökitésének máig egyik legfontosabb forrása a vallás maradt." (OrbánSzántó 2005, 67 o.)

A szerzők felfogásában a vallás tehát egyáltalán nem jelentős dimenzió a társadalmi tőke elmélet és kutatás európai hagyományában, azonban olyan tényezö, melynek létét - főleg kulturális okokból - nem szabad figyelmen kívül hagyni. A kérdés későbbi kutatásakor azonban figyelembe kell vennünk a szerzök megjegyzését, miszerint a vallás és vallásosság bizonyos esetekben káros hatásokat is előidézhet a társadalomban.

Pusztai Gabriella volt a társadalmi tőke elmélet felekezeti oktatással, kutatással kapcsolatos felhasználásának a magyarországi úttörője, munkája ezzel a kérdéssel kapcsolatban iránymutató jellegü (Pusztai 2004). A szerző kutatást végzett a felekezeti iskolák mai társadalmi szerepéról és az általuk ellátott funkciókról. Emellett oktatásszociológiai szempontból vizsgálta a felekezeti iskolákba járó diákokat. Eredményei szerint Magyarországon is igaz, hogy a felekezeti iskolások, akik hatékony normák által összetartott, stabil kapcsolathálózathoz tartoznak, kedvezőbb mértékben döntenek a továbbtanulás mellett, mint nem felekezeti iskolás társaik. Ez megfelel J. S. Coleman elgondolásának a zárt és effektív normákra épülő kapcsolatokkal kapcsolatban, amelyek szerinte a leghatékonyabb társadalmi tőkét 
generálják. A vizsgálat bizonyította továbbá, hogy a felekezeti iskolába járók toleránsabbak más etnikumok tagjaival szemben, és alacsonyabb mértékben próbálták ki a drogokat, mint nem felekezeti iskolába járó társaik. Ezen pozitív tényezők fó okaként Pusztai Gabriella a társadalmi tőkét és a személyes vallásosságot jelöli meg (Pusztai 2004, 299-300 o.).

\subsection{EGY KÍSÉRLET A VALLÁSI TÁRSADALMI TŐKE MODELLEZÉSÉRE}

Az elméleti tapasztalatok illetve a szemlézett amerikai és európai szakirodalmak alapján megkíséreltem elkészíteni a vallási társadalmi tőke működésének grafikus modelljét, mely a 32. ábrán látható. Illusztrálni próbáltam, hogy az egyes szerzők által felvetett szempontok hogyan járulnak hozzá a társadalmi tóke vallási dimenziójának alakulásához, illetve az hogyan hat vissza rájuk. Meg kívántam jeleníteni, hogy ez a társadalmi tőke dimenzió is képes pozitívan vagy negatívan befolyásolni a társadalmi integrációt. Elmondható, hogy a vallásnak illetve vallási közösségeknek komoly hatása lehet tagjainak életre és a társadalmi életre egyaránt (vö. Máté-Tóth - Nagy 2008), melynek múködési mechanizmusát ez az ábra hivatott szemléltetni.

\section{2. ábra - A társadalmi tőke vallási dimenziójának elemei}

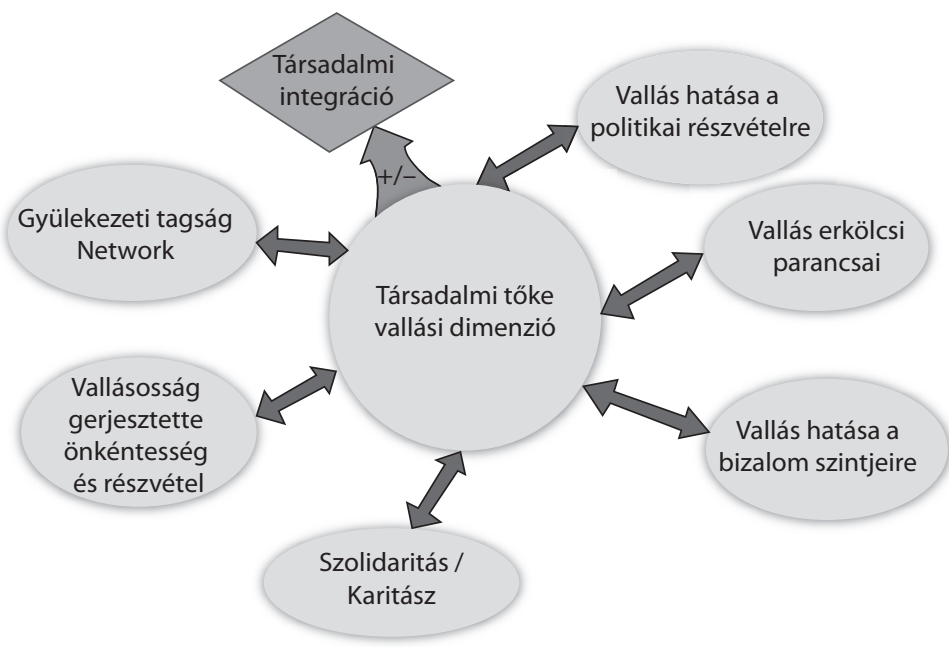

Forrás: saját szerkesztés 


\subsection{TANULSÁGOK}

Ebben a fejezetben kísérletet tettem a társadalmi tőke és vallás kapcsolatának bemutatására. Kitértem a vallási társadalmi tőkére, mint olyan konceptuális és empirikus keretre, amely segítségünkre lehet a vallási közösségek tipologizálásában. A vallási társadalmi tőke elmélet legjelentősebb - főként amerikai - teoretikusainak munkáit tekintettem át, elsősorban olyan példákkal, melyek az Egyesült Államokból származnak. A munka célja a vallás dimenziójának markáns megjelenítése volt, mivel úgy gondolom, hogy bár Magyarországon az intézményes vallásosság társadalmi szinten nem meghatározó tényező, sok más országban az, ezért a társadalmi tőke elmélet szempontjából mindenképpen bemutatásra érdemes. Észak-Amerikában az intézményes vallásosság nagyobb jelentőséggel bír, mint Magyarországon, ezért az ott zajló elméleti vitákból és kutatási eredmények megismeréséből és összehasonlításából fontos tapasztalatokat szerezhettünk a társadalmi tőke és a vallás kapcsolatáról. Egyetértek és Magyarországon is igazolhatónak vélem James S. Coleman megállapítását, melyben a szerző a vallási hálózatok tagjait általában több társadalmi tőkével rendelkezőnek tételezi, mint nem vallásos társaikat. A magyar társadalmi tőke vizsgálatokban a vallás fontossága és szerepe tehát két tényezőtől függ: országos vagy regionális mintán zajlik-e a kutatás, mint jelen munka esetében. Ebben az esetben a vallás jelentősége alacsony mértékủ lesz. Azonban ha konkrét társadalmi hálózatok vizsgálatakor alkalmazzuk a koncepciót, a társadalmi tőke vallási dimenziója hazánkban is jelentőséghez juthat. Jó példa erre Pusztai Gabriella kutatása, illetve saját kutatásunk a Jehova Tanúi és a Baptisták körében. Középtávon véleményem szerint a vallási társadalmi tőke átveheti a korábbi tipologizálási módozatok helyét a kortárs társadalomtudományban, amennyiben a vallási közösségeket társadalmi hozzájárulásuk alapján kívánjuk kategorizálni, nem pedig absztrakt vallási-ideológiai dimenziók mentén. 


\section{2. ÖSSZEFOGLALÁS}

Munkámban a társadalmi tőke és a területi kötődés teóriák összefüggéseinek megvizsgálására vállalkoztam. A vizsgálatot egyrészt elméleti, másrészt empirikus szempontból végeztem, a magyar régiók összehasonlítása illetve két esettanulmány példáján. Bemutattam a társadalmi tőkével kapcsolatos legjelentősebb szerzők gondolatait és az elmélet legfontosabb dimenzióit. Megvizsgáltam a területi identitás elmélet irodalmát is, ám ebből főként a területi kötődés dimenzióját emeltem ki, és jártam körbe elméleti és empirikus szempontból. A két elmélet kapcsolódásait igyekeztem feltárni. Az elméleti vizsgálódás tekintetében vállalkozásom sikeresnek bizonyult, hiszen kimutatható volt az összefüggés a két térségi jellemző között. Mivel mindkét elmélet a társadalmi integrációval és kohézióval hozható összefüggésbe, illetve operacionalizációjuk általában szintén a társadalmi integráltság más megnyilvánulásainak vizsgálata érdekében történik, a kapcsolódás köztük egyértelmüen magyarázható. Az elméleti részben feltártam, hogy a regionális versenyképesség közgazdasági megközelítésủ mérése, illetve a regionális kormányzati és intézményrendszer politikatudományi hatékonyság mérése esetén a társadalmi tőke és a területi kötődés egy harmadik jellemzőben kerül összegzésre egyes szerzők által. Ezt a jellemzőt területi tőkének nevezik. Ez az eredmény egyértelmủen a két elmélet erős kapcsolatára utal.

A társadalmi kohéziót és integrációt vizsgáló térségi kutatások is rendszeresen együtt használták fel a társadalmi tőke és a területi kötődés elméleteket. Mivel mindkét elmélet - a társadalmi tőke és a területi kötődés egyaránt visszajelzi, indikálja az adott térség helyi társadalmának integráltságát illetve kohézióját, így ez a használat nem meglepö.

Az irodalmak szemlézése és az empirikus munka tervezése során meggyöződtem róla, hogy a területi tőke és a területi kohézió / integráció elméletek konceptualizálása és mérésre operacionalizálása lényegesen nehezebb feladat, mint a társadalmi tőke és a területi kötődés elméletek esetében. A társadalmi tőke elmélet sok kutató véleménye szerint így is az operacionalizálhatóság határán van, 
és ebben az írásban is csupán néhány eleme alapján tudtam rá vonatkozóan következtetéseket levonni. A területi kötődés mérése kevésbé bonyolult dolog, ám az eredmények érvényessége szempontjából az is komoly felkészültséget kíván meg. Így amellett, hogy a területi tőkére illetve a területi kohézióra vonatkozó kutatások igazolták a társadalmi tôke és a területi kötődés kapcsolatát a helyi társadalmak esetében, azoknak mérésre történő felhasználása aligha egyszerü feladat.

A társadalmi tőke mérésre operacionalizálása szempontjából az általánosított bizalom és az intézményekbe vetett bizalom koncepcióját használtam fel. Ez azonban az elméleti részben bemutatott dimenziókhoz képest csupán kicsi szelete annak a nagy egésznek, amit a társadalmi tőke a kutatók véleménye szempontjából jelent. Konszenzusos definíciót a tudományos közlemények vizsgálatakor nem találtam, annál több versengő értelmezés került azonban a látóterembe. A kutatásban fóként Putnam ${ }^{26}$ elgondolását követve határoztam meg a társadalmi tőkét. A másodelemzést a rendelkezésre álló adatfájlok kérdőíveinek lehetőségei alapján, a lehető legnagyobb érvényességre törekedve végeztem el.

A területi identitás elemei közül a területi kötődést választottam ki vizsgálatomhoz. Az identitás elmélet nagy komplexitása és bonyolultsága miatt arra törekedtem, hogy valamilyen egyszerü, hatékony és érvényes formában mérni, illetve mérésre operacionalizálni lehessen azt. A területi kötődés használata mellett szólt az, hogy a legtöbb régiókat kutató szerző azt használta munkája empirikus részében. A munka eredményeként közre bocsátottam a kutatás témájában hasznos elméleti irodalmak feldolgozását. Továbbá elvégeztem egy empirikus elemzést a Magyarországra vonatkozó Eurobarometer adatok alapján. A területi kötödés kérdőíves mérésével kapcsolatban megállapítottam, hogy az Eurobarometer kutatás mérési módszertana konszenzusosan elfogadott a szakterület szerzöi körében. Természetesen, ha mélyebbre megyünk, és a területi kötődés összetevőivel és képződésével kívánunk foglalkozni, nem feltétlen fedezhető fel konszenzus a kérdés kutatói között.

Az empirikus elemzés szempontjából megoldandó kérdés volt a vizsgált területi szintek feltételezett jelentéstartalma az Eurobarometer kérdőíves interjú kontextusában. Ezt a nehéz módszertani kérdést azzal a felvetéssel kellett lezárnom, hogy egy Európai Unióról szóló kérdőíven a régióról szóló kérdések esetében a megkérdezettek feltehetően a NUTS 2-es szintủ régiókra gondolnak, és nem másfajta régiók jutnak az eszükbe. (Lásd: 3. Tábla)

26 Csak egy kis részét mutattam be a Putnam munkásságát érintő kritikáknak írásom keretein belül. Így nem tértem ki például Pippa Norris kritikájára. Lásd pl.: Pippa Norris (1996) Does Television Erode Social Capital? A Reply to Putnam. In: Political Science and Politics. vol 29. no 3. 
A régiók helyi társadalmainak lakossága körében végzett vizsgálódás alapján vizsgáltam meg a társadalmi tőke fogalom jelentésének értelmezését. Az EUTE/ ESS kutatás kérdései alapján végzett módszertani kísérletem során az általánosított bizalmat használtam a társadalmi tőke indikátoraként. Konfirmációs faktorelemzéssel teszteltem az általánosított bizalom invarianciáját. Mivel a vizsgálat segítségével meg tudtam állapítani, hogy a különböző régiók lakossága mást ért az általánosított bizalom koncepcióján, ezért nem beszélhetünk invarianciáról. E fejlemény azt jelenti, hogy az egyes régiók helyi társadalmai jelentősen eltérő felfogással bírnak az általánosított bizalommal kapcsolatban. Ezt alátámasztják az invariancia mérés mellett az egyes térségek jelentősen eltérő átlagértékei.

Megállapítható tehát, hogy nincs egységes értelmezése az általánosított bizalomnak - mely sok szerző szerint a legfontosabb konkrét megjelenési formája a társadalmi tőkének - a különböző régiók lakosságát reprezentáló minták között. Ez arra utal, hogy a térségek lakosságai rendelkeznek saját, más térségek lakosságaitól különböző vélemény és jelentés-attribúciós készlettel az általánosított bizalommal, és így a társadalmi tőkével kapcsolatban is.

Vizsgálódásunk egyúttal alátámasztotta, hogy a mérésre operacionalizált társadalmi tőkének a lakosság körében sincs egységes felfogása.

A társadalmi tőke és a területi kötődés közötti kapcsolat nem igazolható egyértelműen minden térségi szint esetében. Sem a vizsgált elméletek, sem az elemzett adatok között nem található meggyőző összefüggés, ha az Európához kötődést és a társadalmi töke szintet vetjük össze. Eszerint az európai szint túl távoli a megkérdezettek szokásos élethelyzetétől. Illetve az ahhoz való kötődésük az elméleti részben kifejtettek szerint feltehetően még alakulóban van. A hagyományos területi szintek (település, nemzet) esetében az összefüggés jelenlétét viszont nagyobb eséllyel lelhetjük fel, föleg a település esetében. A régiók esetében e kutatás eredménye az elméleti összefüggés fellelése, és annak empirikus igazolása felé tett lépés. Az összefüggés meglétére empirikus példaként hozható fel a DélDunántúli és az Észak-Magyarországi régiók esete. Az összehasonlítás alapjaként kínálkozik az ESS/EUTE kérdöív harmadik hullámának 2006 év végén, és 2007 év elején végzett adatfelvétele, melynek adatfelvételi időszaka közel egybeesik az Eurobarometer adatok 67.1-es hullámának 2007. február - márciusi felvételével. Ezáltal az időbeli torzítások hatását nagy részben ki tudjuk küszöbölni, ám az eltérő módszertanból adódó torzításokat nem.

A két régió esetében az általánosított és intézményes bizalom alapján mért társadalmi tőke és a területi kötődés adatai esetében világosan látszik a tendencia, mely a 
koncepciók empirikusan együtt járását, kapcsolatát jelzi. A Dél-Dunántúlon az intézményi bizalom szintje az Európai Parlament irányában magas, és növekvő regionális kötődéssel párosul. Észak-Magyarország esetében az Eurobarometer esést mutat a területi kötődés minden vizsgált típusában. Az intézményesített bizalom esetében pedig az Európai Parlamentben való bizalom a többdimenziós skálázás grafikonján e térség esetében nem helyezkedik el közel egyetlen más bizalomtípushoz sem, ellentétben a többi térség grafikonjaival. Ez jelzi, hogy a régió lakosságának területi kötődései és az intézményesített bizalma általában (illetve kifejezetten az Európai Parlamentben való bizalom esetében) együtt mozog. Az általánosított bizalom szempontjából elmondható, hogy Észak-Magyarország az emberekbe vetett bizalom szempontjából hatodik a magyar régiók között. Az összefüggést ezek az „együtt járások" igazolni látszanak. A fentiek alapján első hipotézisemet, miszerint a területi kötődés a társadalmi tőke elmélet részeként funkcionál területi vizsgálódások esetében, - így a magyar régiók helyi társadalmai esetében is - föként elméleti eredmények alapján, de részben empirikus bizonyítások eredményeképpen is igaznak tételezem.

Empirikus elemzéseimben és az eredmények összehasonlításakor az Európához kötődés jelentése feltehetően eltér a többi, szubnacionális szinthez való kötődés jelentésétől. Példa erre a fentebb említett Észak-Magyarországi régiós eset, illetve a szegedi esettanulmány faktorelemzése. A Szeged Studies 2004 adatbázis alapján a kötődések faktorelemzéses vizsgálatakor egyértelmúen látható volt, hogy az Európai Unióhoz való kötődés kiesett az eljárásból, azaz erről a területi szintről az emberek teljesen másképpen gondolkodtak, mint a többiröl. Ebben az idöszakban a szegediek gondolkodásában a régióhoz való kötődés szinte teljesen megfeleltethető volt a megyékhez való kötődés mintáinak. Az Eurobaromter későbbi hullámainak elemzésekor tapasztalhattuk azt a folyamatot, amikor a kötődések változásai feltehetően a viszonyulások változásait jelentették. A „konvencionális” területi egységek esetében e hipotézist az elméleti irodalmak igazolták, ám a régiók és az európai szint esetében én ugyanezt nem tudtam megtenni.

Munkám kiemelten fontos része a vallási társadalmi tőkéről szóló esettanulmány. Az esettanulmányban felvetettem egy új irányt a vallási közösségek tudományos tipologizálásában. Ennek megértéséhez kontextusba helyeztem a vallás kérdését: bemutattam a pluralizmus elgondolását, valamint a vallási különbségek történelmi alakulását. Kitértem a létező tipológia bemutatására és empirikus adatokkal történő alátámasztására. A régi tipologizálással kapcsolatos legfontosabb kritikám alapja az egyik dimenzió, az exkluzivitás felettébb absztrakt és nehezen értelmezhető jellege. Az új tipologizálása módszer javaslatom szerint a vallási 
társadalmi tőke használata a vallási közösségek tipologizálása céljából. Így megszabadulhatunk az absztrakcióktól, és a közösségek társadalmi realitásaival kapcsolatban is egyértelmü képhez juthatunk. A vallás témája a magyar társadalomban és a régiók helyi társadalmaiban zajló összehasonlító elemzés során nem bírt nagy jelentőséggel, ám az azt nemzetközi szakirodalmakon és példákon keresztül bemutató fejezet megmutatta fontosságát. Az elmélet ilyen alapos bemutatása egyedi a magyar társadalmi tőkekutatásban.

A hipotéziseim kapcsán tehát elmondható, hogy első hipotézisem, azaz „A területi kötődés és a társadalmi tőke elmélet összekapcsolódnak területi vizsgálódások esetében, így a magyar régiók helyi társadalmait reprezentáló minták esetében is. Azaz a meglévő bizalom, reciprocitás, részvétel, tolerancia és helyi kötődés határozza meg az adott térség társadalmi integráltságát és kohézióját, mely sok más dimenzióra is hatással van. Befolyásolja a gazdasági és a politikai dimenziót, valamint a természeti környezet állapotát is. A területi kötődés és a társadalmi tőke „együtt jár”, egyik a másik szempontjából meghatározónak tekinthető. A nagyobb egységnek a társadalmi tőke tekinthető." igazoltnak tekinthető, a kutatás elméleti és empirikus eredményei alapján.

Második feltételezésem, miszerint „A társadalmi tőkének és a területi kötődésnek nem alakult még ki konszenzusos értelmezési kerete és tartalma a különböző magyar NUTS 2-es régiók lakosságának vizsgálata esetében. A mérési invariancia eléréshez az operacionalizálást és a konceptualizálást térségenként kellene elvégezni.” szintén igaznak bizonyult, elvégzett próbáink alátámasztották az egyes területi szintek közötti különbségeket.

Harmadik elgondolásom, mely szerint ,minden térségi szint esetében igaz, hogy az adott térségben tapasztalható területi kötődés szint és a térség társadalmi-tőke szintje között egyértelmü összefüggés, elméleti és empirikus együtt járás tapasztalható. Célom, hogy ezen állítást a magyar régiók (NUTS 2) esetében empirikusan is megpróbáljam igazolni." csupán részleges igazolást leltem fel. Igaz a kijelentés a lokális kötődés esetében, azonban igazolhatósága kérdéses a középszintü kötődések esetében. Az Európai szint esetében pedig a hipotézis egyáltalán nem igazolható.

Összegzésként elmondható, hogy kutatásaimban művem írása során igyekeztem a társadalmi töke és a területi kötődés teóriákat elméleti és empirikus szinten egyaránt összekötni, és azokkal kapcsolatban releváns és tudományos szempontból hasznos elemzéseket közreadni. Az esettanulmányokban a kutatás elméleti és módszertani fố sodra mellett kitekintést kívántam adni egy speciális minta illetve egy speciális téma szempontjából. 


\section{FELHASZNÁLT IRODALOM}

Almond, G. - Verba, S. (1963). The Civic Culture: Political Attitudes and Democracy in Five Nations: Princeton University Press.

Anderson, B. (1983). Imagined Communities. Reflections on the Origin and Spread of Nationalism. London: Verso.

Angelusz R. - Tardos R. (2003). Miért mennek el mégis? Századvég, 2003(Tél).

Arany O. V. - C. Gyurokné Dr. Bódi (2004). A Dél-Dunántúli Régió Szociális Helyzetelemzésének Összefoglalója, Dél-Dunántúli Regionális Forrásközpont.

Arató K. (2000). Szociális párbeszéd az Európai Unióban. Budapesti Közgazdaságtudományi és Államigazgatási Egyetem, Budapest.

Armstrong, H. - J. Taylor (2000). Regional Economics and Policy. Oxford, Blackwell Publishing.

Arts, W. - L. Halman (1999). „New Directions in Quantitative Comparative Sociology: An Introduction." International Journal of Comparative Sociology 40(1): 1-12.

Bartal Anna Mária (2005). Nonprofit elméletek, modellek, trendek. Budapest, Századvég Kiadó

Beckford, J. A. (1989): Religion and Advanced Industrial Society. Unwin Hyman, London.

Bellah, R. - Madsen, R. - Sullivan, W. M. - Swidler, A. - Tipton, S. M. (1996). Habits of the Heart: Individualism and Commitment in American Life. Berkeley and Los Angeles: University of California Press.

Bellah, R. (1998). Community Properly Understood: A Defense of ,Democratic Communitarism'. In A. Etzioni (szerk.), The Essential Communitarian Reader (pp. 15-19). Lanham, Maryland, Rowman \& Littlefield Publishers.

Bourdieu, P. (1977). Outline of a Theory of Practice: Cambridge University Press. Bourdieu, P. - Passeron, J.-C. (1977) Reproduction in education, society, culture. London, Sage Publications. 
Bourdieu, P. (1979). La distinction. Paris: Les editions de minuit.

Bourdieu, P. (1980). Le Capital Social. Notes Provisoires. Actes de la recherche en sciences sociales. vol 31. janvier 1980. 2-3.

Bourdieu, P. (2001). The Forms of Capital. The Sociology of Economic Life, 96-111. Bőhm, Antal (2000). Térségi identitás Magyarországon. In F. Glatz (Ed.), Területfejlesztés és közigazgatás-szervezés (pp. 111-126). Budapest: Magyar Tudományos Akadémia.

Bradshaw, Y. - Wallace, M. (1991). Informing Generality and Explaining Uniqueness: The Place of Case Studies in Comparative Research. International Journal of Comparative Sociology, 32(1), 154-171.

Brehm, J. - Rahn, W. (1997). „Individual level evidence for the causes and consequences of social capital." American journal of political science 41: 888-1023.

Brunner G. (1995). Nemzetiségi kérdés és a kisebbségi konfliktusok KeletEurópában. Budapest: TLA.

Bruter, M. (2005). Citizens of Europe? The Emergence of a Mass European Identity. New York, Palgrave Macmillan.

Bugovics Z. (2004). A területi identitás és a társadalmi siker. In G. Szakál - A. A.

Gergely (Eds.), Társadalmi tőke, karrieresélyek, viselkedésminták. Budapest.

Bugovics Z. (2007). Társadalom, Identitás és Területfejlesztés. Budapest, L'Harmattan Kiadó.

Buzan, B. - Wæver, O. - de Wilde, J. (1998). Security: A New Framework for Analysis. Boulder London: Lynne Rienner Publishers.

Byrne, B. M. (2001). Structural Equation Modeling with AMOS. Mahwah, New Jersey, Lawrence Erlbaum Associates, Inc.

Byrne, B. M. (2004). „Testing for Multi Group Invariance Using AMOS Graphics: A Road Less Traveled." Structural Equation Modeling 11 (2): 272-300.

Camagni, R. (2009). Territorial capital and regional development. In: (Capello, R. - Nijkamp, P. szerk.) Handbook or regional growth and development theories. Northampton, MA. Edward Elgar Publishing. 118-132.

Cartwright,A. - Kovács K. - Sik E. et al (2006) Social capital, regional development, and Europeanisation in Hungary - a literature review. Paper presented at the first SOCCOH Conference. Letöltés ideje: 2010. január 5. 16.00. Forrás: http:/www.lse.ac.uk/collections/ESOCLab/pdf/Social\%20capital\%20and\%20 Regional\%20Development\%20in\%20Hungary.pdf

Casanova, J. (1995) Vallás és Közösség Kelet és Nyugat-Európában. 2000 Folyóirat 4. sz. 6-11. 
Casanova, J. (2006): Rethinking Secularization: A Global Comparative Perspective. The Hedgehog Review / Spring and summer, 06, 7-22.

Charmaz, K. (2006). Constructing grounded theory. Thousand Oaks, London.

Chen, F. F. (2007). Sensitivity of Goodnes of Fit Indexes to Lack of Measurement Invariance. Structural Equation Modeling 14(3): 464-504.

Coleman, J. (1973). Loss of Power. American Sociological Review, 38(1), 1-17.

Coleman, J. A. (2003). Religious Social Capital - Its Nature, Social Location, and Limits. In C. Smidt (Ed.), Religion as Social Capital: Producing the Common Good (pp. 33-47). Waco, TX: Baylor University Press.

Coleman, J. S. (1988). Social Capital in the Creation of Human Capital. The American Journal of Sociology 94: 95-120.

Coleman, J. S. (1990). Foundations of Social Theory. Cambridge, MA.: Belknap Press of Harvard University Press.

Cox, E. (1995). A Truly Civil Society. Sydney, ABC Books.

Cox, E. (1998). Measuring Social Capital As Part of Progress and Well-Being. Measuring Progress. Is Life Getting Better? R. Eckersley. Collingwood, Victoria, CSIRO Publishing 157-167.

Cox, E. (2007). The Functional Value of Social Capital. Australian Journal of Social Issues 42(4): 503-512.

Cronbach, L. J. (1951). „Coefficient alpha and the internal structure of tests.” Psychometrika 16(3): 297-334.

Csizmadia Z. (2008) Kapcsolathálózatok és Társadalmi Tőkék. In: Némedi, D. (szerk.) Modern Szociológiai Paradigmák. Budapet, Napvilág Kiadó. pp. 265320.

Cuba, L. - Hummon, D. M. (1993). A Place to Call Home: Identification with Dwelling, Community, and Region. Sociological Quarterly, 34, 111-131.

Davidov, E. (2008). „A Cross-Country and Cross-Time Comparison of the Human Values Measurement with the Second Round of the European Social Survey." Survey Research Methods 2(1): 33-46.

Durkheim, E.(1986). Atársadalmi tények magyarázatához. Budapest, Közgazdasági és Jogi Könyvkiadó.

Durlauf, S. N. (1999): The case „against” social capital. Focus, 20/3, 1-5.

Eastis, C. M. (1998). „Organizational Diversity and the Production of Social Capital: One of These Groups Is Not Like the Other." American Behavioral Scientist 42(1): 66-77. 
Edwards, B. és Foley, M. W. (1998). Civil Society and Social Capital Beyond Putnam. American Behavioral Scientist 42(1), 124-139.

Elias, Anwen (2008). Introduction: Whatever Happened to the Europe of the Regions? Revisiting the Regional Dimension of European Politics. Regional and Federal Studies. vol. 18. issue 5. 483-492.

Esser, Hartmut (2008) The two meanings of social capital. In: Castiglione, D. - Van Derh, J. W. (2008) The Handbook of social capital. Oxford, Oxford University Press. pp.22-49.

EUTE (é.n.). Európai társadalomtudományi Elemzések Módszertana. Forrás: internet. Letöltés ideje: 2010.09.20. 11:00. Cím: http://www.esshu.hu/modszertan.

Faragó L. (2005). A Jövöalkotás Társadalom-Technikája. Budapest-Pécs: Dialóg Campus Kiadó.

Field, J. (2003). Social Capital. London and New York, Routledge.

Fuchs, E., L. Minnite, et al. (1998). Political Capital and Political Participation. New York, Columbia University. School of International and Public Affairs.

Fukuyama, F. (2007). Bizalom. Budapest, Európa.

Fukuyama, F. (2000): Social Capital and Civil Society. IMF Working Paper, $\mathrm{WP} / 00 / 74$.

Füstös, L., E. Kovács, et al. (2004). Alakfelismerés (Sokváltozós Statisztikai Módszerek). Budapest, Új Mandátum Könyvkiadó.

Füzér, K. - Gerő, M. - Sík, E. - Zongor, G (2005) A társadalmi tőke növelésének lehetöségei fejlesztéspolitikai eszközökkel. Fejlesztéspolitika társadalmi hatásai 4. Budapest, TÁRK. Elérés: 2010.01.06. 16:00. Cím: http://www.tarki.hu/adatbank-h/kutjel/pdf/a768.pdf

Füzér, K. - Gerő, M. - Sík, E. - Zongor, G. (2006): Társadalmi tőke és fejlesztés. Elérés: 2016.01.04. 16:00. Cím:http://www.tarsadalomkutatas.hu/kkk. php?TPUBL-A-703/publikaciok/tpubl_a_703.pdf

Gerbner, George (2000). A média rejtett üzenete - válogatott tanulmányok. Osiris, Budapest.

Glaser, B. G. - A. L. Strauss (1968). The discovery of grounded theory: strategies for qualitative research. Weidenfield and Nicholson, London.

Govier, T. (1998). Dilemmas of Trust. London, Ithaca, McGill - Queen's University Press.

Granovetter, M. S. (1973). The Strength of Weak Ties. American Journal of Sociology 78(6): 1360. 
Green, G., P. - Haines, A. (2016): Asset Building \& Community Development. SAGE Publications, Inc.

Greeley, A. M. (1997). Coleman revisited: religious structures as a source of social capital. American Behavioral Scientist 40(5), 587-594.

Gregory, R. (1999). Social Capital Theory and Administrative Reform: Maintaining Ethical Probity in Public Service. Public Administration Review 59(1): 63-64.

Griffin, E. (2001). Bevezetés a kommunikációelméletbe. Harmat, Budapest.

Grootaert, C. (1998). Social Capital: The Missing Link? Unpublished Working Paper The World Bank.

Grootaert, C. - T. Van Bastelaer (2002). The Role of Social Capital in Development: An Empirical Assessment, Cambridge University Press.

Haesly, R. (1999). Types and Levels of European Attachment in Scotland and Wales. Paper presented at the European Community Studies Association Sixth Biennial International Conference.

Hanifan, L. (1916). The rural school community centre. Annals of the American Academy of Political and Social Science 67, 130-138.

Harrach G. (2013): A magyarországi szekularizáció egyes statisztikai összefüggései. Történelmi keresztény egyházak térvesztése a 2011-es népszámlálás tükrében. http://evangelikus.hu/sites/default/files/szekularizacio_2013.pdf.

Hazell, R. (2001). Introduction: the First Year of Devolution. In R. Hazell (Ed.), The State and the Nation: Imprint Academic.

Hazell, R. (2003). Introduction: The Dynamism of Devolution in its Third Year. In R. Hazell (Ed.), The State of the Nations 2003: Imprint Academic.

Hollis, M. (1998). Trust Within Reason, Cambridge University Press.

Hooghe, L. - Marks, G. (2006). Unraveling the Central State, but How? Types of Multi-Level Governance. The American Political Science Review. vol. 97. no. 2. 233-243.

Horváth G. (1997). Európai integráció, keleti bővítés és a magyar regionális politika. Tér és Társadalom, 11(3), 17-56.

Horváth G. (2001). Európai Regionális Politika. Budapest-Pécs: Dialóg Campus. Horváth G. (2002). A regionális folyamatok kutatása és a területi statisztika. Területi Statisztika 5. (42.) évf.)(4): 307-320.

Horváth G. (2005). Magyarország térszerkezete és a régió intézménye. Területi Statisztika 8(4): 309-323.

Hutchison, W. R. (2003). Religious Pluralism in America. Yale University Press. New Haven and London. 
ICPSR (2005). Eurobarometer 63.4: European Union Enlargement, the European Constitution, Economic Challenges, Innovative Products and Services, MayJune 2005. Ann Arbor, Michigan: ICPSR.

Jacobs, J. (1961). The Death and Life of Great American Cities. New York, Random. Jefferey, C. (2000). Sub-National Mobilization and European Integration: Does it Make any Difference?. Journal of Common Market Studies. Vol. 38. Issue 1. 1-23. Jensen, O. B. - T. Richardson (2004). Making European Space. New York, Routledge.

Kákai L. (2000). Megyei identitás a Dél-Dunántúlon 1994-1998. In F. Glatz (Ed.), Területfejlesztés és közigazgatás szervezés (pp. 183-208). Budapest: Magyar Tudományos Akadémia.

Kearns, A. - Forrest R. (2000). Social Cohesion and Multilevel Urban Governance. Urban Studies 37(5-6):995-1017.

Kearns, A. and Forrest, R. (2001). Social Cohesion, Social Capital and the Neighbourhood. Urban Studies, 38(12): 2125-2143

Kocsis K. - Kovács Z. (2001). A cigány népesség társadalomföldrajza. A Cigányok Magyarországon. F. Glatz. Budapest, Magyar Tudományos Akadémia: 13-20. Kopp Mária (2008. szerk.), Magyar lelkiállapot 2008. Semmelweis Kiadó, Budapest.

Kovách, I. - Nagy Kalamász, I. (2006). Társadalmi és területi egyenlötlenségek. Társadalmi Metszetek. K. Imre. Budapest, Napvilág Kiadó: 161-176.

Lechner, F., J.,: Secularization", in Hans J. HILLERBRAND (ed.), Encyclopedia of Protestantism (Vol. 4), Routledge, New York, 2003, 1701-1707.

Lengyel, Gy. - Göncz, B. (2010): A magyar EU-tagság a közvéleményben. In.: Kolosi T.-Tóth I. Gy. (szerk.): Társadalmi riport 2010, 527-548.

Lengyel I. (2003). Verseny és Területi Fejlődés. Szeged, JATE Press.

Lin, N. (2001) Social Capital: A Theory of Social Structure \& Action. Cambridge, Cambridge University Press.

Lukovics M. (2004) A regionális identitás szerepe a regionális gazdaságfejlesztésben. In: (Czagány, L. - Garai, L. szerk.) A szociális identitás, az információ és a piac. SZTE GTK Közleményei, Szeged, JATE Press. 214-228.

Marks, G. (1998). Territorial Identities in the European Union. In J. J. Anderson (Ed.), Regional Integration and Democracy: Expanding on the European Experience (pp. 69-94). Boulder: Rowman \& Littlefield. 
Maseda, M. - Gómez, I. (2003). Capital social: las relaciones sociales afectan al desarrollo. documento incluido dentro de la Biblioteca Digital de la Iniciativa Interamericana de Capital Social, Ética y Desarrollo.

Máté-Tóth A. - Nagy G. D. - Török P. (2008) Az új vallási közösségek viszonya a társadalomhoz. In: Vallásosság változatok (szerk. Máté-Tóth - Nagy) Szeged, Jatepress. pp. 29-46.

Massey, D. (2005). For Space. London, Sage Publications.

McGuire, M. B. (2001). Religion: The Social Context. Belmont, California, Wadsworth Pub. Co.

Moreno, L. (1999). Local and global: Mesogovernments and territorial identities. Nationalism and Ethnic Politics 5(3 és 4): 61-75.

Moscovici S. (2002). Társadalom-lélektan. Osiris, Budapest.

Nagy Terézia (2004). Kapcsolatháló elemzés egy szegedi hajléktalan csoportban. In: Pászka, Imre (szerk.) A látóhatár mögött. (pp. 91-139) Belvedere, Szeged.

Némedi D. (2008). Bevezetés. In D. Némedi (Ed.), Modern Szociológiai Paradigmák (pp. 15-68). Budapest: Napvilág Kiadó.

Nemes Nagy, J., Ed. (2005). Regionális Elemzési Módszerek. Regionális Tudományi Tanulmányok. Budapest, ELTE Regionális Földrajzi Tanszék.

Németh Zs. (2011): Az urbanizáció és a térbeli társadalomszerkezet változása 1990 és 2001 között. KSH kutatási jelentések 93.

Oláh M. (2002). Hol és miért vagyunk otthon? Új Horizont, XXX(1).

Onyx, J. - Bullen, P. (2000). Measuring social capital in five communities. The Journal of Applied Behavioral Science, 36, 23-42.

Orbán A. - Szántó, Z. (2005). Társadalmi tőke. Erdélyi Társadalom, 3(2), 55-70.

Paasi, A. (2000). Re-constructing regions and regional identity. Paper presented at the Nethur lecture; The Alexander von Humboldt Lectures Series. from http:// www.ru.nl/socgeo/colloquium/Paasi1.pdf

Paasi, A. (2002a). Place and region: regional worlds and words. Progress in Human Geography, 26(6), 802-811.

Paasi, A. (2002b). Regional Transformation in the European Context: Notes on Regions, Boundaries and Identity. Space \& Polity, 6(2), 197-201.

Paasi, A. (2003). Region and place: regional identity in question Progress in Human Geography, 27(4), 475-485.

Paasi, A. (2005). Remarks on Europe's Transforming Meta-geography. Geopolitics, $10(3), 580-585$.

Pálné Kovács I. (1990). A Helyi Politika. Budapest, Akadémiai Kiadó. 
Pálné Kovács I. (1999). Régiók az ezredfordulón? A terhes örökség és a jövő modernizációs kihívásai. Tér és Társadalom, 13(3), 59-77.

Pálné Kovács I. (2000). Térsszervezési stratégiák Magyarországon. In F. Glatz (Ed.), Területfejlesztés és közigazgatás-szervezés (pp. 29-56). Budapest: Magyar Tudományos Akadémia.

Pálné Kovács I. (2001a). Régiók Magyarországa - ultima ráció? Comitatus: önkormányzati szemle, 11(5), 5-9.

Pálné Kovács I. (2001b). Regionális Politika és Közigazgatás. Budapest-Pécs: Dialóg Campus Kiadó.

Pálné Kovács I. (2002). A politikai regionalizáció esélyei Magyarországon. Comitatus: önkormányzati szemle, 12(1-2), 6-19.

Pálné Kovács I. (2008). Helyi Kormányzás Magyarországon. Budapest - Pécs, Dialóg Campus Kiadó.

Pálné Kovács I. (2009). A kutatásról és a vizsgált régióról. In: (Pálné Kovács, I. szerk.) A politika új szintere, a régió. Budapest-Pécs, PTE BTK IDI - Századvég Kiadó. 7-22.

Pálné Kovács I. A regionális önkormányzatok és a regionális politika (területfejlesztés) irányítása. Magyar Köztársaság Belügyminisztériuma.

Pászka I. (2007) Narratív történetformák. Budapest - Szeged, Osiris - Belvedere. Pászka I. (2008). Europa Centrala: Dimensiunile Semnificatiei. TEME DE SOCIOLOGIE ROMANESCA A MODERNITATII. V. Negoita. Cluj Napoca, Grinta: 5-40.

Polányi K. (2004) A nagy átalakulás. Korunk gazdasági és politikai gyökerei. Budapest, Napvilág Kiadó.

Portes, A. - Sensenbrenner, J. (1993) Embeddedness and Immigration: Notes on the Social Determinant of Economic action. The American Journal of sociology, 98 (6), pp. 1320-1350.

Portes, A. - Landolt, P. (1996). The downside of social capital. The American Prospect, 26: pp. 18-21.

Portes, A. (1998). Social Capital: Its Origins and Applications in Modern Sociology. Annual Review of Sociology, 24, 1-24.

Portes, A. (2000). The Two Meanings of Social Capital. Sociological Forum, 15(1), 1-12.

Pusztai G. (2004). Iskola és közösség. Budapest: Gondolat.

Putnam, R. D. - Leonardi, R. - Nonetti, R. Y. (1993). Making Democracy Work: Civic Traditions in Modern Italy. Princeton, NJ.: Princeton University Press. 
Putnam, R. D. (1995). „Bowling Alone: America’s Declining Social Capital.” Journal of Democracy 6(1): 65-78.

Putnam (2000) Bowling alone: the collapse and revival of American community. New York, Simon and Shuchter.

Putnam, R. D. - K. A. Goss (2004). Introduction. Democracies in Flux: The Evolution of Social Capital in Contemporary Society. R. D. Putnam, Oxford University Press: 3-21.

Putnam, R. D. - L. M. Feldstein (2004). Better Together. New York, Simon and Schuster Paperbacks.

Ragin, C. C. (1987). The Comparative Method: Moving Beyond Qualitative and Quantitative Strategies. Berkeley, University of California Press.

Rechnitzer J. (1998). Területi stratégiák. Budapest-Pécs, Dialóg Campus.

Rechnitzer J. (2004). A területi tervezés rendszere a területfejlesztési törvényben.

In: Település és városszociológiai szöveggyüjtemény. Budapest, Gondolat. 222232.

Rico, A. - Fraile, M. - Gonzalez, P. (1998). Regional decentralisation of health policy in Spain: Social capital does not tell the whole story. West European Politics, 21(4), 180-199.

Rothstein, B. (2004): Social Trust and Honesty in Government: A Causal Mechanisms Approach. In.: Creating Social Trust in Post-Socialist Transition. Political evolution and institutional change Palgrave Macmillan, 13-30.

Rus, A. - H. Iglic (2005). „Trust, Governance and Performance: The Role of Institutional and Interpersonal Trust in SME Development." International Sociology 20(3): 371-391.

Santos, J. R. A. (1999). „Cronbach's alpha: A tool for assessing the reliability of scales." Journal of Extension 37(2): 1-5.

Schrijver, F. J. (2003). Electoral performance of regionalist parties and perspectives on regional identity in French regions. Paper presented at the ECPR Joint Sessions.

Schumacker, R. E. - R. G. Lomax (2004). A Beginners' Guide to Structural Equation Modeling. Mahwah, New Jersey, Lawrence Erlbaum Associates.

Seligman, A. B. (1997). The Problem of Trust. Princeton, New Jersey, Princeton University Press.

Selznick, P. (1998). Social Justice: A Communitarian Perspective. In: A. Etzioni (szerk.), The Essential Communitarian Reader (pp. 61-71). Lanham, Maryland, Rowman \& Littlefield Publishers. 
Skrabski Árpád (2008). A társadalmi tőke változásai Magyarországon az átalakulás időszakában. In: Kopp Mária (szerk.), Magyar lelkiállapot 2008. Semmelweis Kiadó, Budapest, pp. 121-130.

Stanley, D. (2003). What Do We Know about Social Cohesion: The Research Perspective of the Federal Government's Social Cohesion Research Network. Canadian Journal of Sociology, 28(1): 5-18

Stark, R., Bainbridge, W. (1985): The future of religion. Secularization, Revival and Cult Formation. University of California Press

Stokes, Jane C (2008). A média- és kultúrakutatás gyakorlata. Gondolat, PTE Kommunikáció- és Kultúratudományi Tanszék, Budapest-Pécs, 2008.

Stolle, D. - T. R. Rochon (1998). Are All Associations Alike?: Member Diversity, Associational Type, and the Creation of Social Capital. American Behavioral Scientist 42(1): 47-65.

Stone, W. (2000). Social capital, social cohesion and social security. Conference Paper presented at ISSA year 2000 Conference, Helsinki, Finland.

Stone, W. (2001). Measuring social capital: Towards a theoretically informed measurement framework for researching social capital in family and community life. Australian Institute of Family Studies. Research paper no. 24.

Stone, W. - Hughes, J. (2002). Social Capital: Empirical Meaning and Measurement Validity: Australian Institute of Family Studies. Research paper no. 27.

Székelyi M. - Barna I. (2002). Túlélökészlet az SPSS-hez. Budapest, Typotex.

Szücs J. (1981) Vázlat Európa három történeti régiójáról. Történelmi Szemle 1981. 3. $s z$.

Thoits, P. A. - L. K. Virshup (1997). Me's and We's: Forms and Functions of social Identity. Self and Identity. R. D. Ashmore and L. Jussim. New York and Oxford, Oxford University Press.

Tomka, M. - Zulehner, P. (2008) Religionen und Kirchen in Ost(Mittel)europa. Ostfildern, Schvabenverlag.

Tomka M. (1996): A vallásszociológia új útjai. Replika, 1996 21-22, 163-171.

Török, P. (2004) Magyarországi Vallási Kalauz 2004. Budapest, Akadémiai Kiadó. Uslaner, E. M. (2001). Volunteering and social capital: How trust and religion shape civic participation in the Untied States. In P. Dekker - E. M. Uslaner (szerk.), Social Capital and Participation in Everyday Life (pp. 104-117). London: Routledge.

Uslaner, E. M. - Badescu, G. (2004): Honesty,Trust, and Legal Norms in the Transition to Democracy: Why Bo Rothstein is Better Able to Explain Sweden 
than Romania. In.: Creating Social Trust in Post-Socialist Transition. Political evolution and institutional change Palgrave Macmillan, 31-51.

Utasi, Ágnes (2002a). Társadalmi integráció és családi szolidaritás. In: Educatio, 2002 ösz. pp. 384-403.

Utasi, Ágnes (2002b). A bizalom hálója. Mikrotársadalmi kapcsolatok és a szolidaritás. Budapest, Új Mandátum.

Utasi, Ágnes (2008). Éltető kapcsolatok: a kapcsolatok hatása a szubjektívéletminőségre. Budapest, Új Mandátum.

van Houtum, H. - Lagendijk, A. (2001). Contextualising regional identity and imagination in the construction of polycentric urban regions. Urban Studies. vol 4. 747-767.

Wæver, O. (1997). Concepts of security. Copenhagen University, Copenhagen.

Wallace, W. (1990). The Transformation of Western Europe. London: Royal Institute of International Affairs.

Wallis, A. - Crocker, J. - Schechter, B. (1998). Social capital and community building: Part one. National Civic Review, 87, 253-271.

Weber. M. (1987). Gazdaság és társadalom. A megértő szociológia alapvonalai I. Budapest, Közgazdasági és Jogi Könyvkiadó.

Weiss, D. A. (1996). Towards a theory on the formation of social capital. University of Minnesota. Doktori disszertáció, Minnesota.

Wuthnow, R. (1999). Mobilizing Civic Engagement: The Changing Impact of Religious Involvement. In T. Skocpol - M. P. Fiorina (Eds.), Civic Engagement in American Democracy (pp. 331-363). Washingtown, D. C.: BROOKINGS INSTITUTION PRESS. 


\section{ÁBRAJEGYZÉK}

\begin{tabular}{|c|c|}
\hline Ábra neve & Oldalszám \\
\hline 1. ábra - A társadalmi és politikai tőke viszonya & 34. o. \\
\hline 2. ábra - Területi szintek és kapcsolódásaik & 69. o. \\
\hline 3. ábra - A kötődés típusai & 72. o. \\
\hline 4. ábra - A társadalmi tőke legfontosabb dimenziói & 81. o. \\
\hline $\begin{array}{l}\text { 5. ábra - Vázlat a társadalmi tőke és a regionális identitás együttes hatásairól a regi- } \\
\text { onális versenyképességre }\end{array}$ & 83. o. \\
\hline $\begin{array}{l}\text { 6. ábra - Vázlat a társadalmi töke és a területi identitás együttes hatásairól a területi } \\
\text { önkormányzat sikerességére }\end{array}$ & 85. o. \\
\hline $\begin{array}{l}\text { 7. ábra - Konfirmációs faktorelemzés mérési modell az „Általánosított Bizalom” } \\
\text { látens változóval kapcsolatban }\end{array}$ & 100. o. \\
\hline $\begin{array}{l}\text { 8. ábra - Paraméterekkel ellátott (Constrained) modell a metrikus és skaláris invari- } \\
\text { ancia teszteléséhez }\end{array}$ & 101. o. \\
\hline $\begin{array}{l}\text { 9. ábra - Általánosított bizalom: A legtöbb ember megbízható (1-10 skála, átlagér- } \\
\text { tékek) }\end{array}$ & 107. o. \\
\hline $\begin{array}{l}\text { 10. ábra - Általánosított bizalom: Fökomponens pontszámok regionális összehason- } \\
\text { lítása (standardizált) }\end{array}$ & 108. o. \\
\hline $\begin{array}{l}\text { 11. ábra - Intézményekbe vetett bizalom: Fökomponens pontszámok regionális } \\
\text { összehasonlítása (standardizált) }\end{array}$ & 110. o. \\
\hline $\begin{array}{l}\text { 12. ábra - Többdimenziós skálázás adatainak ábrázolás, euklideszi távolság, orszá- } \\
\text { gos adatok }\end{array}$ & 113. o. \\
\hline $\begin{array}{l}\text { 13. ábra - Többdimenziós skálázás adatainak ábrázolás, euklideszi távolság, Köz- } \\
\text { ponti régió }\end{array}$ & 115. o. \\
\hline $\begin{array}{l}\text { 14. ábra - Többdimenziós skálázás adatainak ábrázolása, euklideszi távolság, Nyu- } \\
\text { gat-Dunántúl }\end{array}$ & 116. o. \\
\hline $\begin{array}{l}\text { 15. ábra - Többdimenziós skálázás adatainak ábrázolás, euklideszi távolság, Közép- } \\
\text { Dunántúl }\end{array}$ & 117. o. \\
\hline $\begin{array}{l}\text { 16. ábra - Többdimenziós skálázás adatainak ábrázolás, euklideszi távolság, Dél- } \\
\text { Dunántúl }\end{array}$ & 118. o. \\
\hline $\begin{array}{l}\text { 17. ábra - Többdimenziós skálázás adatainak ábrázolás, euklideszi távolság, Észak- } \\
\text { Magyarország }\end{array}$ & 119. o. \\
\hline $\begin{array}{l}\text { 18. ábra - Többdimenziós skálázás adatainak ábrázolás, euklideszi távolság, Észak- } \\
\text { Alföld }\end{array}$ & 120. o. \\
\hline $\begin{array}{l}\text { 19. ábra - Többdimenziós skálázás adatainak ábrázolás, euklideszi távolság, Dél- } \\
\text { Alföld }\end{array}$ & 121. o. \\
\hline 20. ábra - Településhez kötődés átlaga idősorosan, régiónként (min. 1-max. 4) & 130. o. \\
\hline 21. ábra - Régióhoz kötődés átlaga idősorosan, régiónként (min. 1-max. 4) & 131. o. \\
\hline
\end{tabular}




\begin{tabular}{|c|c|}
\hline 22. ábra - Országhoz kötődés átlaga idősorosan, régiónként (min. 1-max. 4) & 133. o. \\
\hline 23. ábra - Európához kötődés átlaga idősorosan, régiónként (min. 1 - max. 4) & 135. o. \\
\hline $\begin{array}{l}\text { 24. ábra - Kötődés a területi szintekhez, idősoros átlag, országos adatok (min. } 1 \text { - } \\
\text { max. 4) }\end{array}$ & 136. o. \\
\hline $\begin{array}{l}\text { 25. ábra - Kötődés a területi szintekhez, idősoros átlag, Közép-Magyarország (min. } \\
1-\max .4 \text { ) }\end{array}$ & 137. o. \\
\hline $\begin{array}{l}\text { 26. ábra - Kötődés a területi szintekhez, idősoros átlag, Észak-Magyarország (min. } \\
1 \text { - max. 4) }\end{array}$ & 138. o. \\
\hline 27. ábra - Kötődés a területi szintekhez, idősoros átlag, Észak-Alföld (min. 1 - max. 4) & 139. o. \\
\hline 28. ábra - Kötődés a területi szintekhez, idősoros átlag, Dél-Alföld (min. 1- max. 4) & 140. o. \\
\hline 29. ábra - Kötődés a területi szintekhez, idősoros átlag, Dél-Dunántúl (min. 1- max. 4) & 141. o. \\
\hline $\begin{array}{l}\text { 30. ábra - Kötődés a területi szintekhez, idősoros átlag, Közép-Dunántúl (min. } 1 \text { - } \\
\text { max. 4) }\end{array}$ & 142. o. \\
\hline $\begin{array}{l}\text { 31. ábra - Kötődés a területi szintekhez, idősoros átlag, Nyugat-Dunántúl (min. } 1 \text { - } \\
\text { max. 4) }\end{array}$ & 143. o. \\
\hline 32. ábra - A társadalmi tőke vallási dimenziójának elemei & 176. o. \\
\hline
\end{tabular}




\section{TÁBLAJEGYZÉK}

\begin{tabular}{|c|c|}
\hline Tábla neve & \begin{tabular}{|l}
$\begin{array}{l}\text { Oldal- } \\
\text { szám }\end{array}$ \\
\end{tabular} \\
\hline 1. tábla - Eurobarometer konfidencia intervallumok & 18. o. \\
\hline 2. tábla - A hipotézisek konceptualizálása és operacionalizálása & 23. o. \\
\hline 3. tábla - A kötődést vizsgáló kérdés kategóriáinak jelentése & 73. o. \\
\hline $\begin{array}{l}\text { 4. tábla - a területi identitás és a társadalmi tőke föbb dimenzióinak összefüggései és } \\
\text { különbségei }\end{array}$ & 80. o. \\
\hline 5. tábla - Az ESS/EUTE harmadik hullám elemszámok regionális megoszlása & 105. o. \\
\hline $\begin{array}{l}\text { 6. tábla - Az egyes régiók helyezései a két bizalomtípus szempontjából. (Fökompo- } \\
\text { nens pontszám átlag alapján) }\end{array}$ & 111. o. \\
\hline $\begin{array}{l}\text { 7. tábla - Az intézményekbe vetett bizalom átlaga változónként és régiónként (1-10 } \\
\text { skála, átlag érték) }\end{array}$ & 112. o. \\
\hline 8. tábla - Területi kötődések korrelációs mátrixa, idősorosan & 124. o. \\
\hline 9. tábla - Teljes kötődés metszet különböző területi szintek esetében, (\%) & 126. o. \\
\hline 10. tábla - Cronbach Alfa együtthatók az adatok egydimenziós illeszkedésére & 127. o. \\
\hline 11. tábla - Rotált faktorközéppontok faktorsúlyai idősoros formában & 128. o. \\
\hline 12. tábla - A szegediek kötődései a területi szintekhez & 147. o. \\
\hline 13. tábla - Kötődési Faktor mátrix & 149. o. \\
\hline 14. tábla - megyéhez kötődés nemek szerint & 151. o. \\
\hline 15. tábla - régióhoz kötődés nemek szerint & 151. o. \\
\hline 16. tábla - megyéhez kötődés iskolai végzettség szerint & 152. o. \\
\hline 17. tábla - régióhoz kötődés iskolai végzettség szerint & 152. o. \\
\hline 18. tábla - megyéhez kötődés életkor szerint & 153. o. \\
\hline 19. tábla - régióhoz kötődés életkor szerint & 153. o. \\
\hline 20. tábla - Korreláció a megyei és regionális kötődésre (Spearman Rhó) & 154. o. \\
\hline $\begin{array}{l}\text { 21. tábla - Kategorizálás a csoport és a társadalom viszonya, valamint a csoport saját } \\
\text { legitimációs képe alapján }\end{array}$ & 160. o. \\
\hline 22. tábla - Érzése szerint Ön a hazájában saját gyülekezetével... & 162. o. \\
\hline 23. tábla - A magyar társadalom hogyan viszonyul az Ön közösségéhez? & 163. o. \\
\hline 24. tábla - Az Ön véleménye szerint a megváltás elérhető... & 164. o. \\
\hline
\end{tabular}




\section{FELHASZNÁLT ADATBÁZISOK JEGYZÉKE}

Európai Bizottság: Eurobarometer 62.0. 2004. október - november [számítógépes adatfájl]. Végezte: a TNS OPINION \& SOCIAL és menedzselte az EOS GALLUP EUROPE, Brüsszel, megrendelte az Európai bizottság. ZA4229 Edition 1.0, Cologne Germany: Zentralarchiv für Empirische Sozialforschung [terjesztö], 2007.

Európai Bizottság: Eurobarometer 63.4, 2005. május - június [számítógépes adatfájl]. Végezte: a TNS OPINION \& SOCIAL és menedzselte az EOS GALLUP EUROPE, Brüsszel, megrendelte az Európai bizottság. ZA4411, Edition 1.0, Cologne Germany: GESIS, Zentralarchiv für Empirische Sozialforschung [terjesztő], 2007

Európai Bizottság: Eurobarometer 65.2, 2006. március - május [számítógépes adatfájl]. Végezte: a TNS OPINION \& SOCIAL és menedzselte az EOS GALLUP EUROPE, Brüsszel, megrendelte az Európai bizottság.

ZA4506 1st release, Cologne Germany: Zentralarchiv für Empirische Sozialforschung [terjesztő], 2007.

Európai Bizottság: Eurobarometer 67.1, 2007. február - március [számítógépes adatfájl]. Végezte: TNS OPINION \& SOCIAL, Brüsszel, megrendelte az Európai Bizottság. ZA4529, 1st archive release, Cologne Germany: GESIS-ZA [terjesztő], 2007.

Európai Bizottság: Eurobarometer 67.2, 2007. április - május [számítógépes adatfájl].

Végezte: TNS OPINION \& SOCIAL, Brüsszel,megrendelte az Európai Bizottság.

ZA4530, 3rd archive release, Cologne Germany: GESIS-ZA [terjesztő], 2008. 
European Social Survey Wave 3. magyar adatok, 2006. november - 2007. január [számítógépes adatfáj1].

Végezte: Gallup Magyarország.

Letöltve: www.europeansocialsurvey.org, 2008.

Szeged Studies Kutatás 2004-es Hullám, 2004. október-november. [számítógépes adatfájl].

Végezte: Szegedi Tudományegyetem Szociológia Tanszéke

Kutatásvezető: Dr. Feleky Gábor

Kultúra és Vallás Kutatás - Jehova Tanúi adatbázis 2004-ből [számítógépes adatfáj1].

Végezte: Szegedi Tudományegyetem Vallástudományi Tanszéke

Kutatásvezető: Dr. Máté-Tóth András

Kultúra és Vallás Kutatás - Baptista adatbázis 2006-ból [számítógépes adatfáj1].

Végezte: Szegedi Tudományegyetem Vallástudományi Tanszéke

Kutatásvezető: Dr. Máté-Tóth András 
